San Jose State University

SJSU ScholarWorks

Master's Theses

Master's Theses and Graduate Research

1990

\title{
Fluvial stratigraphy, and depositional history of Los Gatos Creek, Coalinga, California
}

David Anthony Trumm

San Jose State University

Follow this and additional works at: https://scholarworks.sjsu.edu/etd_theses

\section{Recommended Citation}

Trumm, David Anthony, "Fluvial stratigraphy, and depositional history of Los Gatos Creek, Coalinga, California" (1990). Master's Theses. 3240.

DOI: https://doi.org/10.31979/etd.3f8z-jqqy

https://scholarworks.sjsu.edu/etd_theses/3240

This Thesis is brought to you for free and open access by the Master's Theses and Graduate Research at SJSU ScholarWorks. It has been accepted for inclusion in Master's Theses by an authorized administrator of SJSU ScholarWorks. For more information, please contact scholarworks@sjsu.edu. 


\section{INFORMATION TO USERS}

The most advanced technology has been used to photograph and reproduce this manuscript from the microfilm master. UMI films the text directly from the original or copy submitted. Thus, some thesis and dissertation copies are in typewriter face, while others may be from any type of computer printer.

The quality of this reproduction is dependent upon the quality of the copy submitted. Broken or indistinct print, colored or poor quality illustrations and photographs, print bleedthrough, substandard margins, and improper alignment can adversely affect reproduction.

In the unlikely event that the author did not send UMI a complete manuscript and there are missing pages, these will be noted. Also, if unauthorized copyright material had to be removed, a note will indicate the deletion.

Oversize materials (e.g., maps, drawings, charts) are reproduced by sectioning the original, beginning at the upper left-hand corner and continuing from left to right in equal sections with small overlaps. Each original is also photographed in one exposure and is included in reduced form at the back of the book.

Photographs included in the original manuscript have been reproduced xerographically in this copy. Higher quality $6 "$ x 9 " black and white photographic prints are available for any photographs or illustrations appearing in this copy for an additional charge. Contact UMI directly to order.

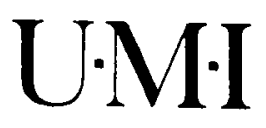

University Microfilms International

A Bell \& Howell Information Company

300 North Zeeb Road. Ann Arbor. MI 48106-1346 USA

$313.761 .4700 \quad 800.521 .0600$ 


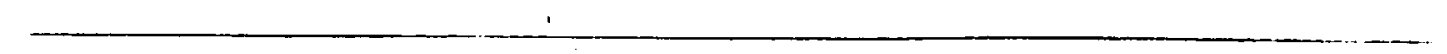


Order Number 1340048

Fluvial stratigraphy, and depositional history of Los Gatos Creek, Coalinga, California

Trumm, David Anthony, M.S.

San Jose State University, 1990 


\title{
FLUVIAL STRATIGRAPHY, AND DEPOSITIONAL HISTORY OF LOS GATOS CREEK, COALINGA, CALIFORNIA
}

\author{
A Thesis \\ Presented to \\ The Faculty of the \\ Department of Geology \\ San Jose State University \\ in Partial Fulfillment \\ of the Kequirements for the Degree \\ Master of Science
}

By

David Anthony Trumm

May, 1990 
Approved for the Department of Geology

Pobertid. Rein

Dr. Robert S. Creel

Deborah Rllach

Dr. Deborah Harden

calm C. Finally

Dr. John C. Tinsley III

Approved for the University

Seven 2\%. Hanford 


\title{
ABSTRACT \\ FLUVIAL STRATIGRAPHY, AND DEPOSITIONAL HISTORY OF LOS GATOS CREEK, COALINGA, CALIFORNIA
}

\author{
by David Anthony Trumm
}

Holocene fluvial deposits of Los Gatos Creek record three episodes of aggradation and three episodes of degradation that occurred during the last 7000 years. Aggradation 1 began before 7700 years ago and lasted until about 6600 years ago. It may have been caused by a change which occurred in the local Holocene climate from dry to wet. Degradation 1 followed about 6400 years ago. It may have been causes by changes in the internal geomorphic variables of the fluvial system. Aggradation 2 began about 4500 years ago and is also attributed to changes in the internal variables. Degradation 2 began about 190 years ago and possibly was caused by the decrease in precipitation about 1760 . Aggradation 3 began about 1850 and was possibly caused by the increase in precipitation about 1826. Degradation 3 occurred after 1955 and is probably partly due to recent subsidence caused by withdrawal of groundwater. 


\section{Acknowledgments}

First and most importantly I'd like to thank John Tinsley who provided valuable guidance during all phases of the field work and gave extensive input throughout many written drafts. John was a strong driving force in helping me to complete this thesis. I'd like to thank the other thesis committee members, R. Scott Creely and Deborah Harden, for taking time for a field visit of the study area and for reviewing and editing the thesis. I'd also like to thank David Andersen who had very helpful comments on organization of the written draft. I thank Brian Atwater who first introduced me to Coalinga and convinced me to pursue my studies there. Ross Stein deserves credit for the generous funding that this project required. The people at Beta Analytic, Steve Robinson at the U.S.G.S. radiocarbon lab, Allen Tucker from San Jose State University, and Larry Toolin at the accelerator lab in Tucson, Arizona provided valuable advice and services for the radiocarbon dating. The section on the Holocene California climate benefitted much from discussions with Dave Adam and Owen Davis. I thank my Mom and Dad for their unending support throughout this entire ordeal. Special thanks to Dad for proofreading several drafts. Doug Prose is credited with introducing me to, and helping me use, the Macintosh for drafting figures. I thank Donna Knifong for putting up with continued chaos and confusion in our office. Thanks also go to Bob Versical for extensive help in the field work. Finally, very special thanks go to Kari Bassett for her continued support and patience during the writing-stage of this thesis. 
TABLE OF CONTENTS

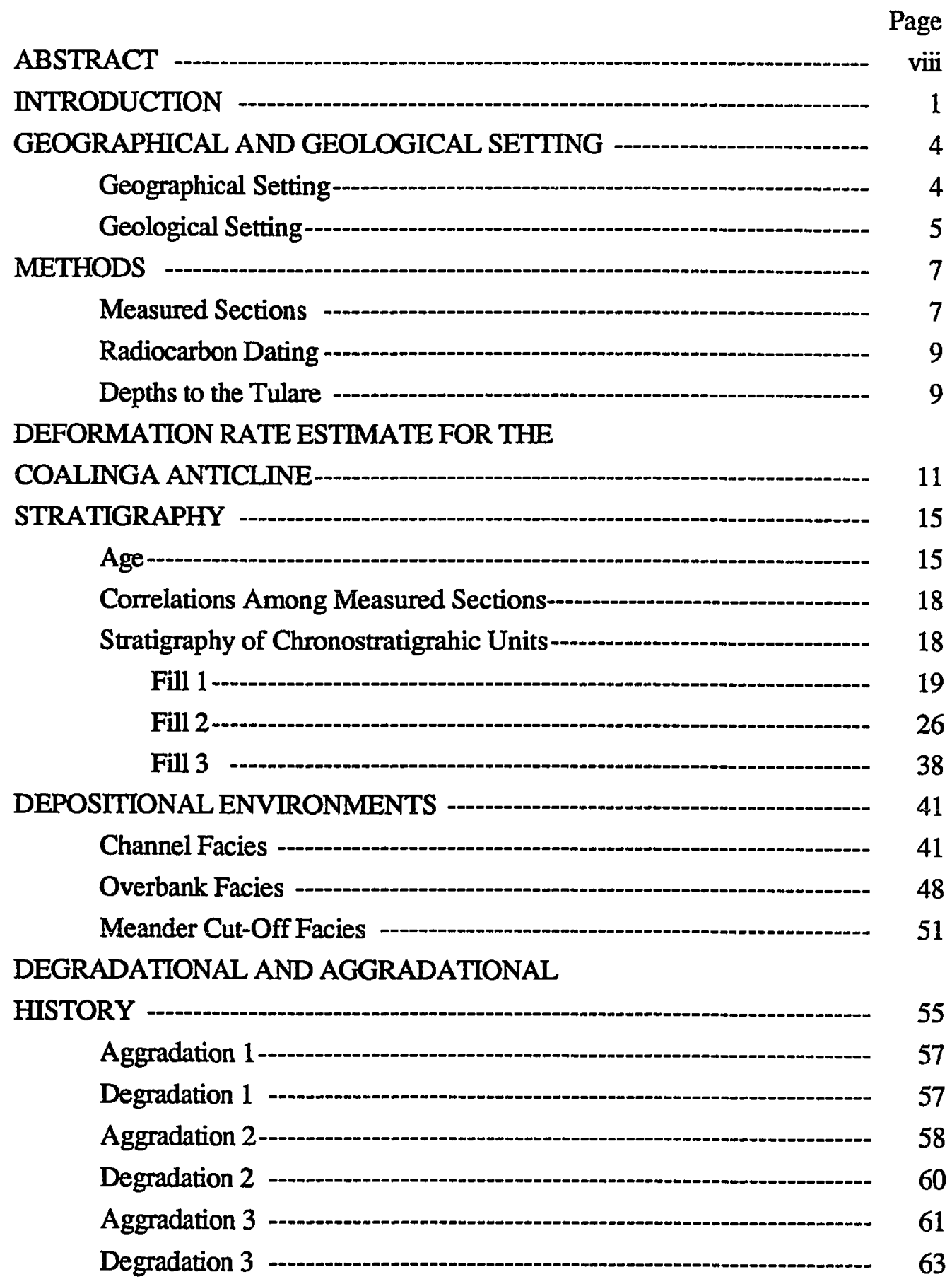




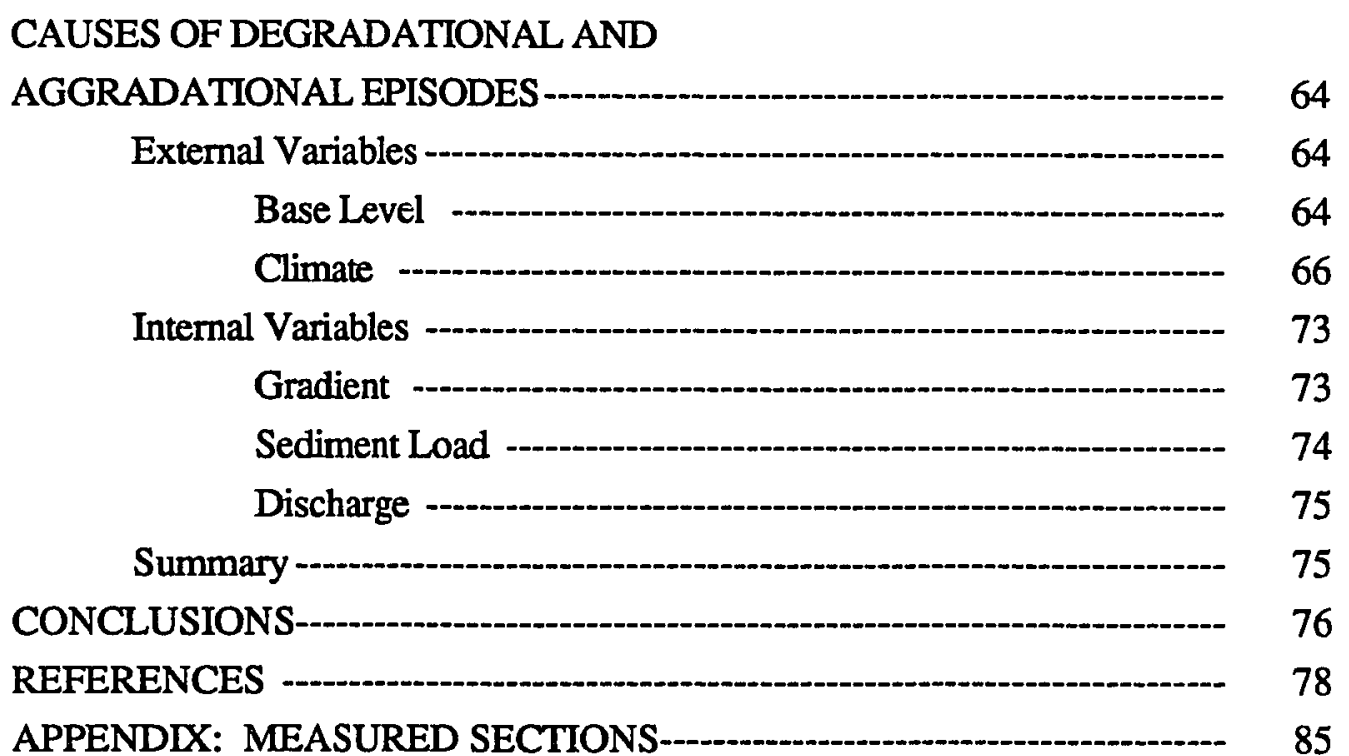




\section{LIST OF ILLUSTRATIONS}

Figure

page

1. Map of the Coalinga Region

2. Topographic Map of the Coalinga Region Showing Measured Section Localities -

3. Structure Contour Map of the Top of the Tulare Formation---------- 13

4. Units Arranged According to Stratigraphic Succession------------ 20

5. Cross Section of Deposits of Los Gatos Creek-- 21

6. Cross Section of Deposits with Thalweg as Datum------------------- 22

7. Unit A Overbank Deposits and Unit $H$ Channel Deposits

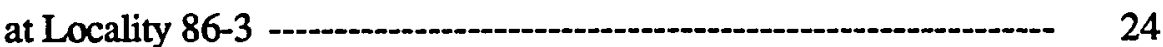

8. Overbank Deposits of Units C, F, G, and H at Locality 101 -.--- 27

9. Overbank Deposits of Unit F at Locality 100 -..- 32

10. Channel Deposits of Unit F at Locality 86-4---------------------- 33

11. Channel Deposits of Unit $\mathrm{H}$ at Locality 86-3

12. Unit I Terrace Near Locality 86-4 ----------------------------------- 39

13. Terrace deposit of Unit I Near Locality 86-4 - - 39

14. Diagram of Deposits of the Point Bar Model ------------------- 42

15. (A) Modern Channel Lag, (B) Modern Point Bar--------------- 44

16. Modern Bank Deposits in Sage Creek, South Dakota --------- 47

17. Diagram of Crevasse Splay Deposits -.-. 50

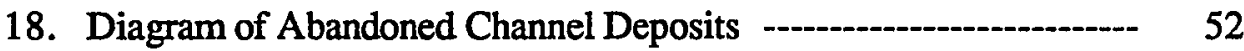

19. Location of Modern Abandoned Channel - - 54

20. Radiocarbon Dates Arranged According to Geographic Position Along Los Gatos Creek -

21. Profile of Unit I Deposits Along Los Gatos Creek ---:-י-:- 62 


\section{LIST OF TABLES}

Table page

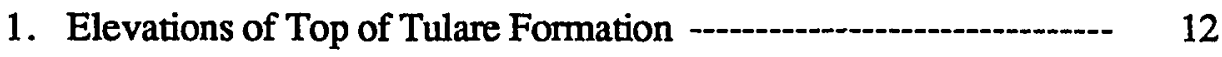

2. Radiocarbon Ages --_-_- 16

3. Listing of Channel Facies Deposits of Fill $2 \ldots$

4. Depositional Rates for Units C, D, E, F, G, and H - - 25

5. California Climatic Changes --- 67

6. Annual Precipitations and Mean Annual Temperatures for Coalinga 70 


\section{INTRODUCTION}

In May of 1983 an earthquake of magnitude $\left(\mathrm{M}_{\mathrm{S}}\right) 6.7$ occurred near Coalinga, along the western margin of the San Joaquin Valley, California (fig.1), a region previously thought by seismologists to have a low seismic potential. Since then, exhaustive geophysical and geological studies have centered on the Coalinga region. These studies were begun because the rupture that caused the earthquake occurred on a previously unknown thrust fault at a depth of about 10 kilometers beneath the eastern margin of the Coast Ranges. This suggested the possibility that the Coast Ranges may be an active fold and thrust belt, and that earthquakes similar to the Coalinga earthquake may occur elsewhere along the 1000-kilometer-long eastern margin of the Coast Ranges.

In order to assess the earthquake potential for the Coalinga region and for similar regions along the Coast Ranges, a comprehensive study of the regional setting of the May 2, 1983, Coalinga earthquake, the structural implications of foldbelt earthquakes for California, and the seismological, geological, and engineering effects of the earthquake were undertaken by the U.S. Geological Survey (U.S. Geological Survey Professional Paper 1487). In one of these studies Atwater and others (in press) estimated Holocene deformation rates for the Coalinga Anticline (expressed on the Earth's surface as Anticline Ridge) using stratigraphic data collected along Los Gatos Creek, a creek that drains Pleasant Valley and trends perpendicular to the anticline (fig. 1). They found that buried alluvial plains identified as coeval overbank deposits, cross the Coalinga Anticline with very little apparent deformation, indicating that the uplift rate for the Coalinga Anticline is no more than $0.1 \mathrm{~mm} / \mathrm{yr}$ during the last 5000 years. In the section in this thesis titled DEFORMATION RATE ESTIMATE FOR THE COALINGA ANTICLINE, the amount of deformation of the Pliocene-to-Pleistocene Tulare Formation in the vicinity of Los Gatos Creek yields a deformation rate estimate for the Coalinga Anticline over a much longer range of time (from 0.5 to as much as 2.2 million years). These estimates of deformation rates are used in the section titled CAUSES OF DEGRADATIONAL AND AGGRADATIONAL EPISODES to appraise the possible role of tectonic uplift on the stream's cut and fill history. 


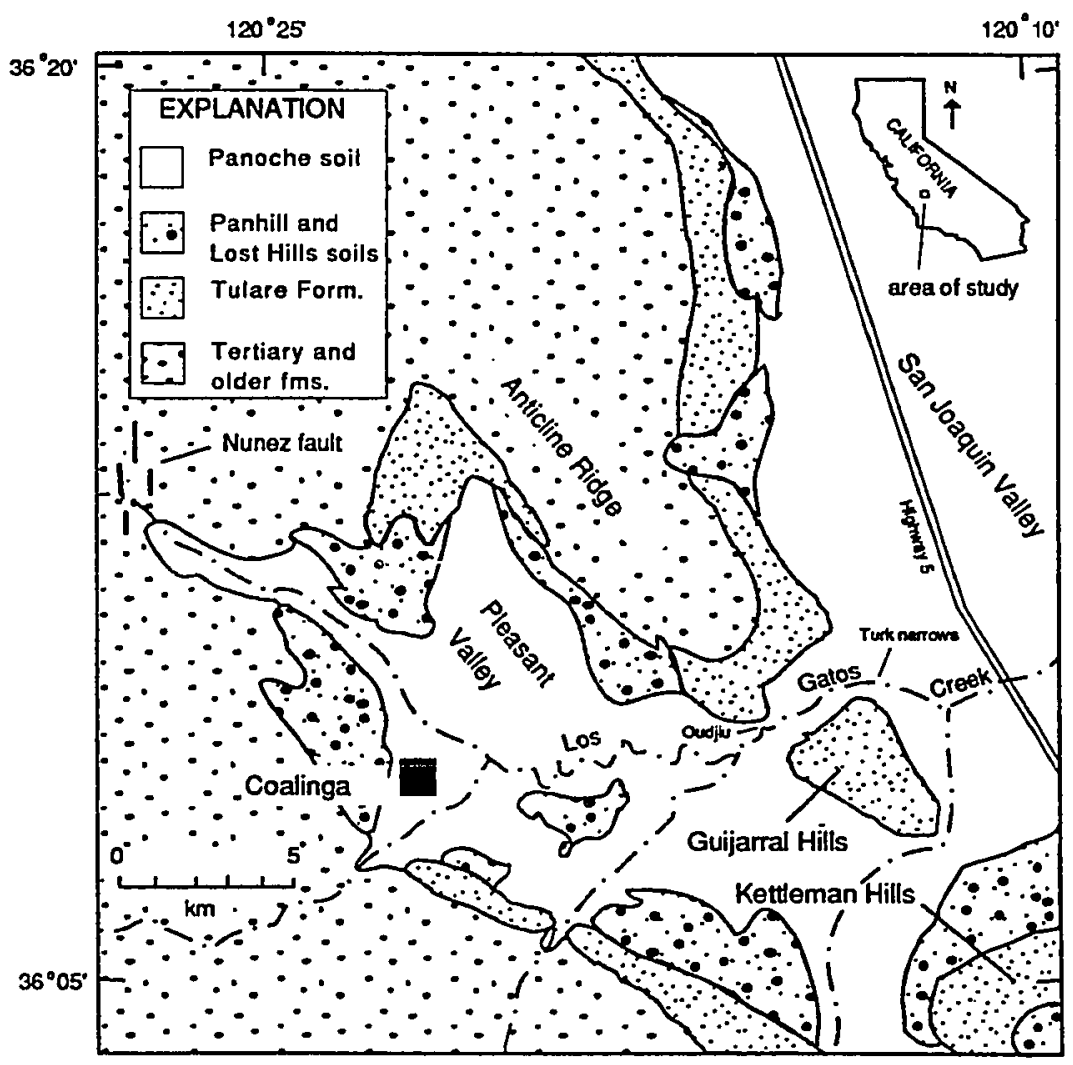

Figure 1: Generalized geologic and soil map of the Coalinga region (from Stein and King, 1984). 
The goal of this thesis is to interpret the aggradational and degradational history for the last 7000 years for Los Gatos Creek. Much of the stratigraphic and radiocarbon data used in this thesis is from Atwater and others (in press). The main purposes of this thesis are twofold. First, the timing of the cut and fill episodes of Los Gatos Creek can be compared to the timing of Holocene climatic cisanges in central California to determine the possible role of Holocene climatic change on fluvial sedimentology in central California. This can be done using the models by Schumm (1977) on how streams can respond to climatic changes. Holocene climatic changes in California have been well studied (Adam and others, 1981; Adam and West, 1983; Batchelder, 1980; Cole, 1983; Davis, 1986; Davis and others, 1985; Mackey and Sullivan, 1986; Moratto and others, 1988; Sims and others, in press; Sullivan, 1985; West, unpublished reports; and Wood, 1975) but little work has been done on the effects of these climatic changes on depositional and erosional events in fluvial systems. Second, this thesis can provide evidence of Quaternary depositional episodes that might correlate with depositional everits elsewhere in the Great Valley and Coast Ranges. 


\section{GEOGRAPHICAL AND GEOLOGICAL SETTING}

\section{Geographical Setting}

The town of Coalinga is located in Pleasant Valley, California, in the Southern Diablo Range west of the San Joaquin Valley and north of the Kettleman Hills (see figure 1 for the locations of these features and for all the following named geographical features). Most of the study area is in Los Gatos Creek, an ephemeral stream which flows from its drainage basin west of Coalinga, through the water gap between Anticline Ridge and the Guijarral Hills, and into the San Joaquin Valley.

The drainage basin for Los Gatos Creek is about 270 square kilometers, and its tributaries Warthan Creek and Jacalitos Creek, that join Los Gatos Creek in Pleasant Valley, have drainage basins on the order of 200 to 300 square kilometers each. The arroyo of Los Gatos Creek has an average width of about 100 to 200 meters and a depth of about 5 to 10 meters below the adjacent alluvial plain. Using a form of the Manning equation, Atwater and others (in press) have estimated maximum and minimum values of channel bankfull capacity along two reaches of the creek. These values are $2190 \mathrm{~m}^{3} / \mathrm{s}$ at Turk Narrows and $8780 \mathrm{~m}^{3} / \mathrm{s}$ at Oudjiu (fig. 1). The maximum recorded discharge for Los Gatos Creek since 1931 is only $130 \mathrm{~m}^{3} / \mathrm{sec}$ and a 50 year flood is probably no more than $500 \mathrm{~m}^{3} / \mathrm{sec}$. Therefore, a typical 50 year flood would not overtop the arroyo's banks. The large width and depth of this channel are due to incision and side-cutting which had probably occurred largely before 1853-54 based on the following data:

In 1853-54 township-subdivision surveyors measured the width of the arroyo everywhere it crossed a section boundary from Coalinga to the San Joaquin Valley, and they measured the depth of the arroyo at one locality about 0.5 mile west of the present Interstate Highway 5 (fig. 1). Their measured widths are very similar to 1984 arroyo widths and their measured depth is about 3.0 meters deeper than the 1984 arroyo depth; because the arroyo dimensions in 1853-54 and 1984 are similar this indicates that most of the incision and sidecutting had already taken place by 1853-54. 


\section{Geological Setting}

This thesis focuses on the upper Holocene portion of the Quaternary sediments filling the Pleasant Valley Syncline and the San Joaquin Valley Syncline. The Pleasant Valley Syncline underlies Pleasant Valley and is separated from the San Joaquin Valley Syncline to the east by the Coalinga Anticline. The Coalinga Anticline is expressed on the surface as Anticline Ridge and as the Guijarral Hills. The folded Cenozoic sedimentary rocks of the Coalinga Anticline reach a thickness of more than 3 kilometers beneath Anticline Ridge and thin westward across Pleasant Valley to a thickness of 1.7 kilometers near Coalinga (Bartow, in press).

The Tulare Formation, the youngest conspicuously folded formation crossing the Coalinga Anticline, was first identified by Watts (1894) and first defined by Anderson (1905). Anderson described the formation as fresh-water deposits of gypsiferous sands and clays at a type locality on the eastern side of the Kettleman Hills, 10 to 15 miles southeast of Coalinga, near the western shore of Tulare Lake. Later, Bull (1964) described the Tulare Formation east of the Ciervo Hills and Panoche Hills (10 miles northeast of Coalinga) as containing cobbles of glaucophane schist, slaty shale, graywacke, red chert, and serpentine detritus. Dibblee (1971) and Lettis (1982) described the Tulare Formation in the vicinity of Coalinga as a moderately consolidated, often cemented, sandstone, siltstone, claystone, and conglomerate. This last description of the Tulare Formation is that used in the present study. The age of the Tulare ranges from 0.5 to 2.2 million years old (Dibblee, 1971; Obradovich and others, 1978; and Lettis, 1982). The post-Tulare Formation Pleistocene and Holocene unconsolidated and poorly consolidated basin fill deposits attain an apparent maximum thickness of about 100 meters near the axis of Pleasant Valley in the vicinity of Los Gatos Creek, and a minimum thickness of 7 meters where Los Gatos Creek cuts through the Coalinga Anticline near Turk Narrows (fig. 1).

The rupture resulting from the May 2, 1983 Coalinga earthquake (magnitude $\left(\mathrm{M}_{\mathrm{S}}\right)$ 6.7) occurred at a depth of about 10 kilometers beneath the Coalinga Anticline at the intersection of a gently southwestward-dipping thrust fault and a steeply southwestward-dipping reverse fault in the Mesozoic Franciscan Formation (Wentworth and Zoback, in press; McGarr and others, in press). 
Displacement propagated down the thrust within the Franciscan Formation and up along the reverse splay which penetrates the Mesozoic Great Valley Sequence and terminates beneath folded Cenozoic sedimentary rocks of the Coalinga Anticline. Aftershocks were scattered throughout the region on both the thrust and reverse faults. In June of 1983, during one of these aftershock events, displacement of up to 65 centimeters occurred at the surface on the Nunez Fault (Rymer and others, in press). The Nunez is a reverse fault and is about 11 kilometers northwest of Coalinga where it perpendicularly crosses Los Gatos Creek (fig. 1). These earthquakes prompted the present study of the Holocene stratigraphy of Los Gatos Creek. 


\section{METHODS}

Collection of the data required measuring stratigraphic sections in the field, and obtaining radiocarbon dates for selected charcoal and wood samples collected within the sections. These data were used to elucidate the depositional history of Los Gatos Creek.

\section{Measured Sections}

Most data for this study were acquired from natural outcrops along stream banks. Good exposures occur about every half kilometer along the stream, with the remainder of the banks obscured by aprons of talus and slumped blocks of alluvium. From the exposures, thirty-five measured sections were completed (see figure 2 for locations of sections and see APPENDIX: MEASURED SECTIONS). Twenty-nine of these are from Atwater and others (in press), and six additional sections were completed for this study. The thirty-five sections range from 2.3 to 10 meters in stratigraphic thickness and from 5 to 350 meters in downstream width, and most extend upward to the present alluvial fan surface. Because talus deposits and younger inset terraces commonly obscure the lower banks of the creek, only a few sections extend downward to the thalweg. The absolute elevation of each section was determined by the U.S.G.S. (Atwater and others, in press) by linking the sections to the National Geodetic Vertical Datum by means of vertical-angle leveling between benchmarks Coalinga RM4 and T1228 (fig. 2). Measurements within all sections were made using hand level, tape, and ruler. Bed thicknesses, grain size, color, primary and secondary sedimentary structures, charcoal content, asbestos content, and lateral continuity of the beds were recorded for each measured section. Five of the six sections measured and described for this thesis were enlarged and deepened using a backhoe. In each case, 3 meters of bank-obscuring talus was removed and a 3-meter-square, 2-meter-deep trench was excavated below thalweg elevations. These trenches, then, extended the vertical exposures of the creek's banks by about 5 meters.

In addition to trenching, 28 exposures were extended beneath the creek bed for this study using a hand soil auger. These exploratory auger holes (11.4 


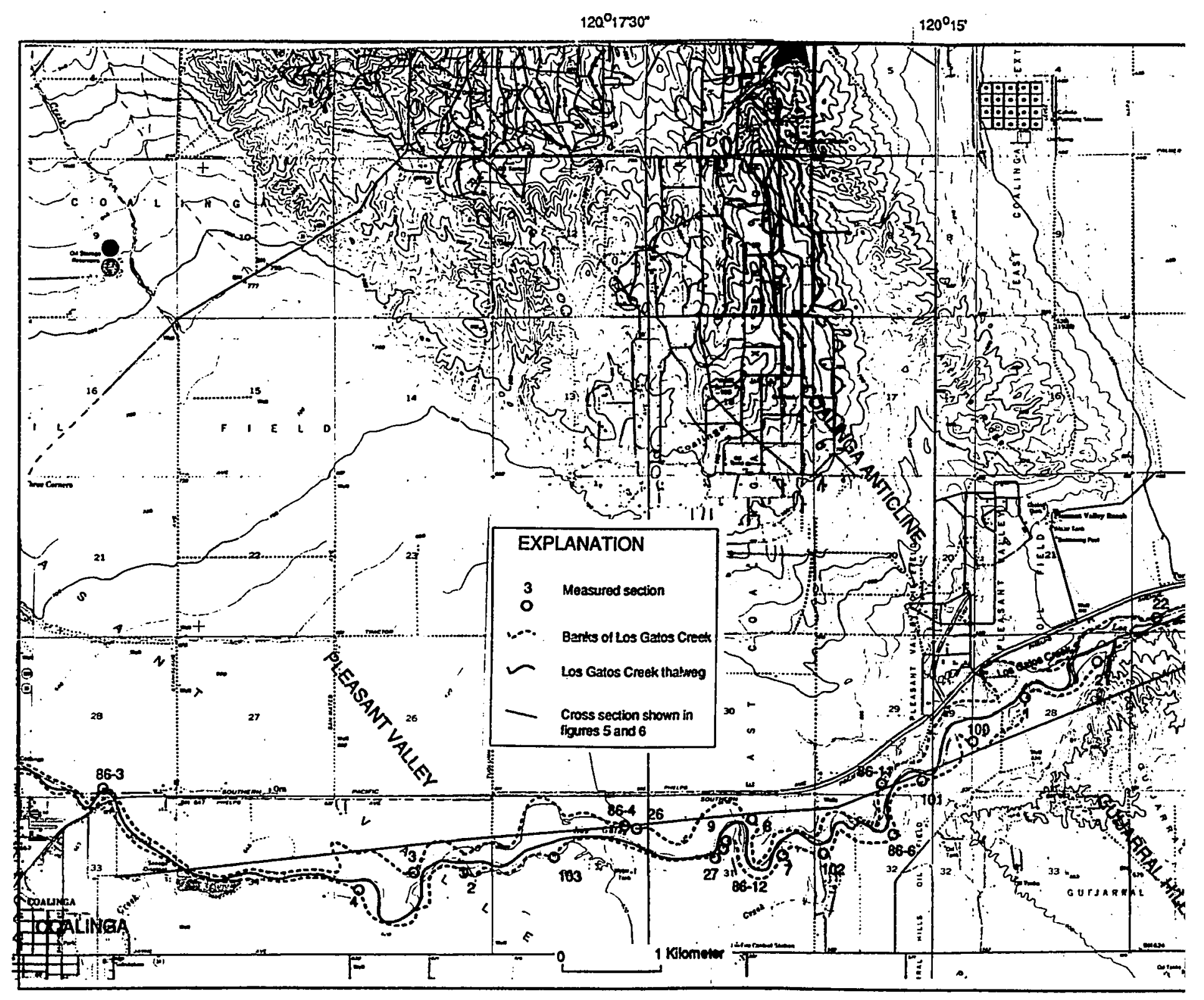

Figure 2: Topographic map of the Coal 


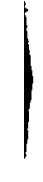




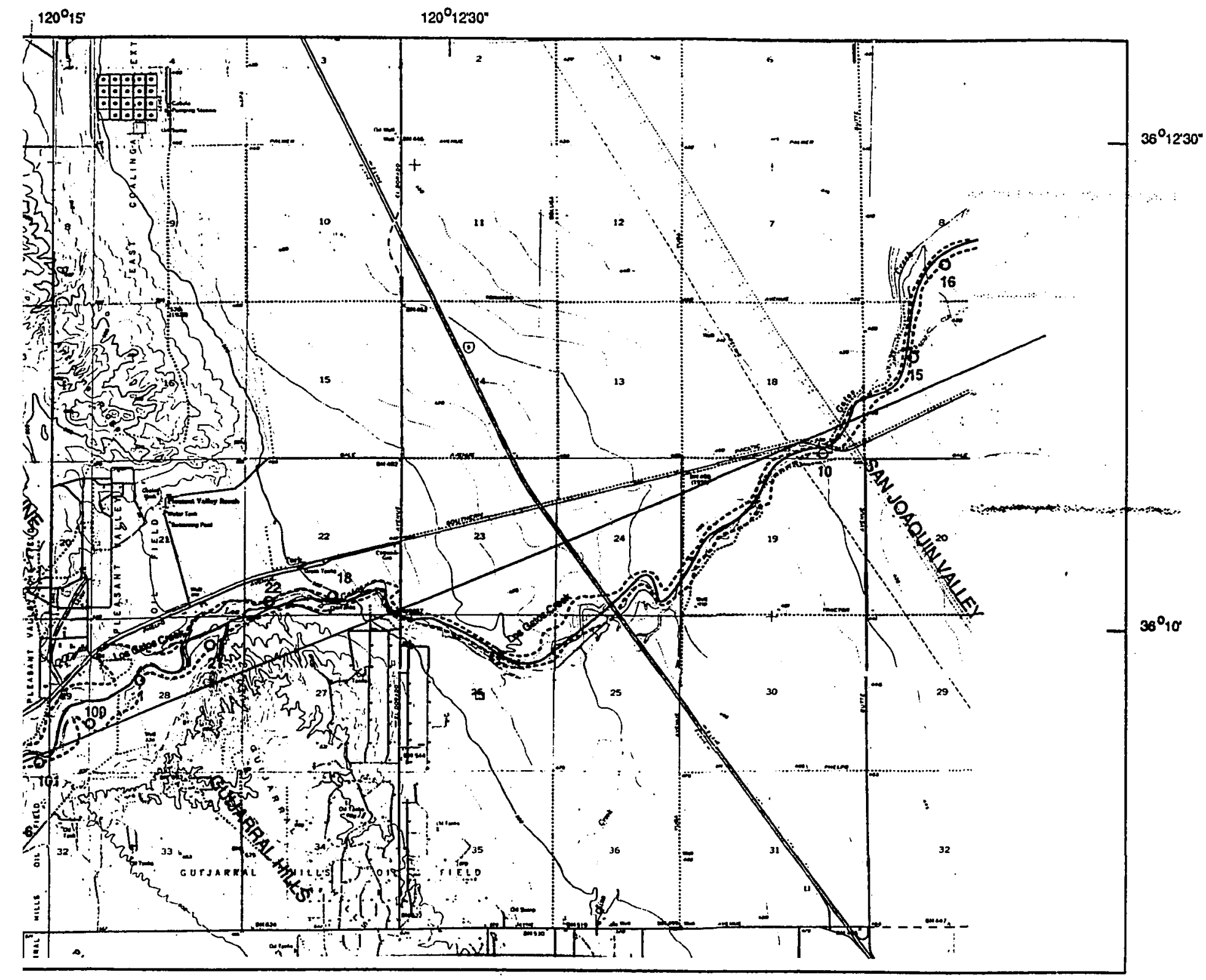

Topographic map of the Coalinga region showing measured section localities. 
$\mid$ 
centimeters in diameter) generally ranged from 2 to 4 meters in depth. This technique was used to ascertain the frequency of overbank deposits and gravel deposits present below thalweg levels in the sections.

\section{Radiocarbon Dating}

Wood and charcoal samples were analyzed for radiocarbon content so as to obtain age control useful for correlating among sections. Sixty ${ }^{14} \mathrm{C}$ ages by Atwater and others (in press) and thirteen additional ${ }^{14} \mathrm{C}$ ages are used in this study. Fifty-four were obtained using the tandem accelerator and mass spectrometer method by the University of Arizona in Tucson, Arizona, while nineteen were obtained by the conventional proportional-gas or liquid-scintillation method by the United States Geological Survey in Menlo Park, California, and by Beta Analytic in Miami, Florida. Because the activity of ${ }^{14} \mathrm{C}$ in atmospheric $\mathrm{CO}_{2}$ has not been constant throughout time, these dates have been calibrated using the calibration curves of Stuiver and Pearson (1986), Pearson and Stuiver (1986), and Pearson and others (1986).

\section{Depths To The Tulare Formation}

The amount of deformation of the Tulare Formation was useful in estimating uplift rates for the Coalinga Anticline. In order to measure the deformation of the Tulare Formation, depths beneath Los Gatos Creek to the top of the Tulare Formation were determined by using two methods: (1) seismicrefraction surveys, and (2) identification of the Tulare Formation in lithologic logs of water wells.

Twelve seismic-refraction surveys were conducted using a sledge-hammer as an acoustical source and measuring P-wave first arrivals with a single channel signal-enhancement seismograph. The Tulare Formation is easily recognized relative to most late Pleistocene and Holocene alluvial deposits because of its high P-wave velocity ( $\mathrm{V}_{\mathrm{p}}$ ranges from 1980 to 2060 meters per second) compared to the overlying deposits ( $\mathrm{V}_{\mathrm{p}}$ ranges from 340 to 850 meters per second).

Depths to the Tulare Formation were also found by interpreting 52 lithologic logs of water wells. In these logs, the top of the Tulare Formation was interpreted 
as the first conglomeratic or cemented horizon below which "cementation" was a generally used attribute of the description. 


\section{ESTIMATED DEFORMATION RATE FOR THE COALINGA ANTICLINE}

The Tulare Formation, a moderately consolidated sandstone, siltstone, claystone, and conglomerate 0.5- to 2.2-million years old (Dibblee, 1971; Lettis, 1982), is the youngest conspicuously folded formation crossing the Coalinga Anticline. The Tulare crops out on the Coalinga Anticline north of Los Gatos Creek with dips ranging from 2 to 25 degrees but is buried beneath younger deposits throughout Pleasant Valley and along the entire reach of Los Gatos Creek except for a small outcrop near Turk Narrows (fig. 2). The degree to which the Tulare Formation is folded can allow an estimate of the deformation rate for the Coalinga Anticline over a much longer time span than can be estimated using the Holocene deposits as was done by Atwater and others (in press). Depths beneath Pleasant Valley to the Tulare Formation were determined by using two methods: (1) seismic-refraction surveys and (2) identification of the Tulare Formation in water well lithology logs (table 1). Combining the seismic-refraction data and the welllog data, a structure contour map drawn on the Tulare Formation has been made (fig. 3) which shows the Tulare to have a maximum difference in elevation of 105 meters between Pleasant Valley and the Coalinga Anticline in the vicinity of Los Gatos Creek. The maximum dip of the Tulare on the west flank of the anticline is 7.9 degrees and on the east flank is 1.3 degrees. This interpretation confirms the Coalinga Anticline to be asymmetric as postulated by Wentworth and Zoback (in press) and as mapped by Dibblee (1971).

Assuming that the Tulare Formation had an initial regional eastward dip comparable to that of the present alluvial plain, then the Tulare Formation has been uplifted on the Coalinga Anticline in the vicinity of Los Gatos Creek by a total of at least 105 meters with respect to synclinal Plcasant Valley. This uplift yields an estimated deformation rate of $0.048 \mathrm{~mm} / \mathrm{yr}$ to $0.21 \mathrm{~mm} / \mathrm{yr}$ which is nearly in agreement with the deformation rate of $0.33 \mathrm{~mm} / \mathrm{yr}$ to $1.33 \mathrm{~mm} / \mathrm{yr}$ estimated by Stein and King (1984) as based on surface dips of the Tulare Formation. These deformation rates and the Holocene deformation rate estimated by Atwater and others (in press) are used in the section titled CAUSES OF DEGRADATIONAL 
Table 1: Elevations of the top of the Tulare Formation as interpreted from refraction line surveys and water well lithologies. Locations are shown on figure 3.

\begin{tabular}{|c|c|c|c|}
\hline $\begin{array}{l}\text { Refraction } \\
\text { line }\end{array}$ & $\begin{array}{l}\text { Line } \\
\text { elevation }(m)\end{array}$ & $\begin{array}{l}\text { Depth to } \\
\text { Tulare (m) }\end{array}$ & $\begin{array}{c}\text { Elevation of } \\
\text { Tulare (m) }\end{array}$ \\
\hline 1 & 156 & 9.0 & 147 \\
\hline 5 & 157.5 & 7.5 & 150 \\
\hline 6 & 162 & 11.0 & 151 \\
\hline 8 & 166.1 & 81.1 & 85 \\
\hline 9 & 162.2 & 48.2 & $\begin{array}{l}114 \\
133\end{array}$ \\
\hline 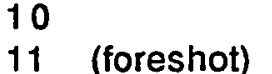 & $\begin{array}{l}153.8 \\
145.6\end{array}$ & $\begin{array}{l}20.8 \\
7.6\end{array}$ & $\begin{array}{l}133 \\
138\end{array}$ \\
\hline 11 (backshot) & 146.2 & 5.2 & 141 \\
\hline 12 (foreshot) & 144.5 & 25.5 & 119 \\
\hline 12 (backshot) & 145.5 & 19.5 & 126 \\
\hline $\begin{array}{l}\text { Well } \\
\text { number }\end{array}$ & $\begin{array}{c}\text { Well } \\
\text { Elevation }(m)\end{array}$ & $\begin{array}{l}\text { Depth to } \\
\text { Tulare }(\mathrm{m})\end{array}$ & $\begin{array}{c}\text { Elevation of } \\
\text { Tulare }(\mathrm{m})\end{array}$ \\
\hline 1 & 175 & 34 & 141 \\
\hline 3 & 174 & 81 & 93 \\
\hline 4 & $176-177$ & 85 & $91-92$ \\
\hline 6 & $170-173$ & 60 & $110-113$ \\
\hline 7 & $170-174$ & 44 & $126-130$ \\
\hline 8 & $172-175$ & 40 & $132-135$ \\
\hline 10 & 189 & 48 & 141 \\
\hline 12 & 186 & 49 & 137 \\
\hline 13 & 198 & 89 & 109 \\
\hline 14 & 197 & 58 & 139 \\
\hline 19 & $194-197$ & 60 & $134-137$ \\
\hline 20 & 189 & 96 & 93 \\
\hline 21 & 183 & 69 & 114 \\
\hline 22 & 212 & 21 & 191 \\
\hline 27 & 200 & 40 & 160 \\
\hline 28 & 202 & 24 & 178 \\
\hline 29 & 202 & 30 & 172 \\
\hline $\begin{array}{l}30 \\
33\end{array}$ & $\begin{array}{l}200 \\
175\end{array}$ & $\begin{array}{l}35 \\
54 ?\end{array}$ & $\begin{array}{l}165 \\
121 ?\end{array}$ \\
\hline 39 & 159 & 2 & 157 \\
\hline 44 & 157 & 15 & 142 \\
\hline $\begin{array}{l}47 \\
48\end{array}$ & $\begin{array}{l}162 \\
164\end{array}$ & $\begin{array}{l}4 \\
15\end{array}$ & $\begin{array}{l}158 \\
149\end{array}$ \\
\hline 49 & 148 & $39-66$ & $109-137$ \\
\hline 50 & 175 & 36 & 139 \\
\hline $\begin{array}{l}51 \\
52\end{array}$ & $\begin{array}{l}178 \\
181\end{array}$ & $\begin{array}{l}40 ? \\
24\end{array}$ & $\begin{array}{l}138 ? \\
157\end{array}$ \\
\hline
\end{tabular}




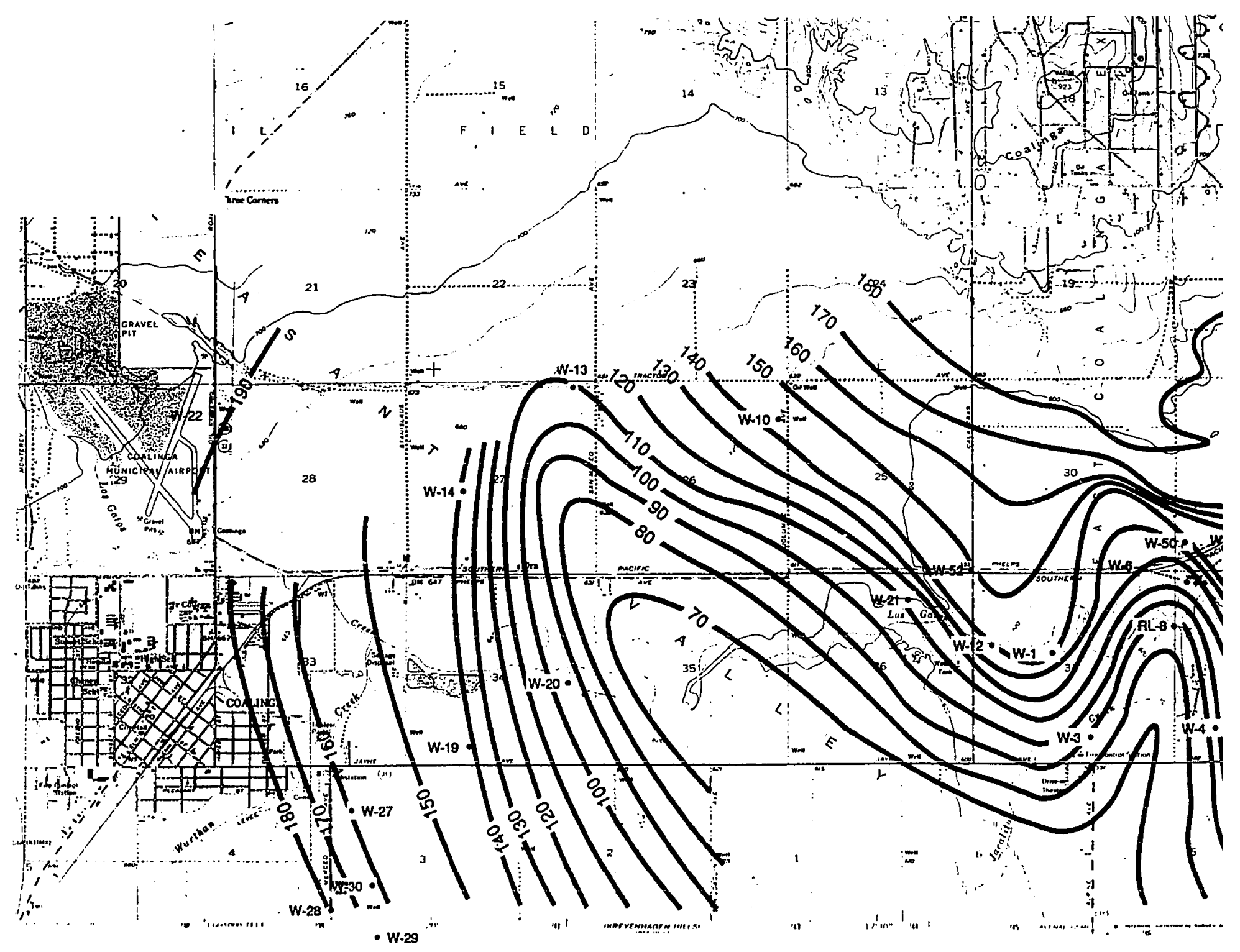

Figure 3: Structure contours showing elevations in meters above sea level c top of the Tulare Formation (QTt of Dibblee, 1971). 
. 


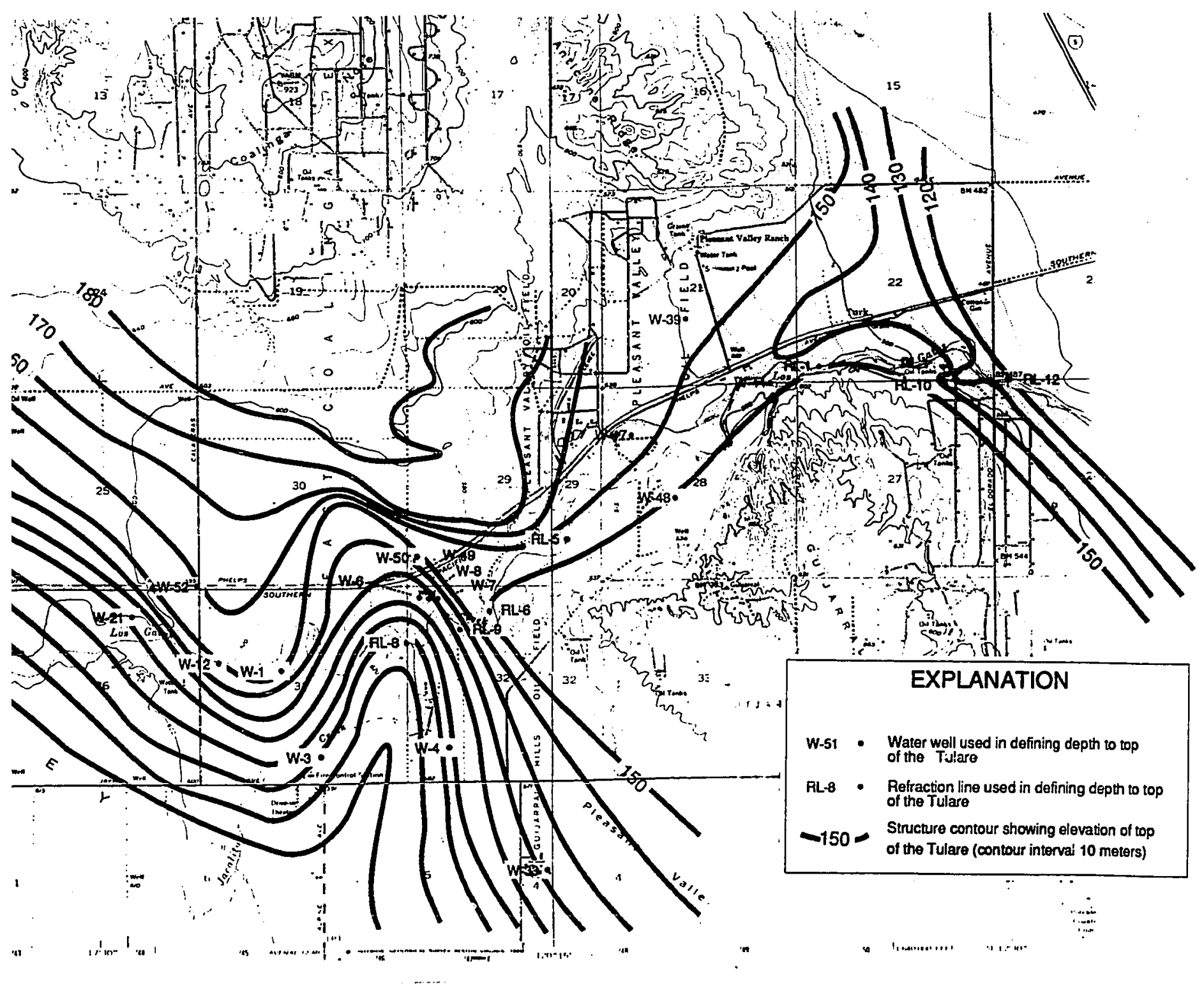

showing elevations in meters above sea level of the Jibblee, 1971). 
AND AGGRADATIONAL EPISODES to determine the effect of uplift of the Coalinga Anticline on the cut and fill history of Los Gatos Creek. 


\section{STRATIGRAPHY}

\section{Age Determinations}

The wood and charcoal used for radiocarbon dating of Los Gatos Creek deposits have been grouped as either detrital material, or burned-in-place (in situ) material (table 2). The burned-in-place material is generally composed of angular, often twig-like, pieces of charcoal or disseminated flecks of charcoal and are commonly found in silty deposits. This charcoal type is always found overlying 1to 2-centimeter thick zones of reddish silt (hue 5YR) which are interpreted to be silt thermally altered by brush fires. Multiple ${ }^{14} \mathrm{C}$ ages within individual charcoal samples, with one exception out of six tests, show striking concordance, and supeiposed charcoal samples within a single outcrop, with two exceptions out of eleven tests, have superposed ${ }^{14} \mathrm{C}$ ages. Therefore, a ${ }^{14} \mathrm{C}$ age obtained from a burned-in-place charcoal sample is interpreted as being closely similar to the age of the host deposit.

The detrital material is typically composed of well-rounded charcoal fragments often associated with asbestos flakes and commonly found in sandy deposits. This charcoal is suspected to have been reworked and can therefore yield an age that pre dates the host deposit. To find out how much older than the host deposit detrital charcoal can be, Atwater and others (in press) dated individual pieces of charcoal from the same aggregate sample to determine a range of ages for that particular sample. Out of 7 tests on detrital deposits, 4 showed no significant statistical difference between the age of individual pieces from a single aggregate sample and 3 showed the individual pieces to have significant statistical differences. Of these three tests, one showed a difference of 490 years, one a difference of 780 years, and one a difference of 1000 years. If one assumes that the charcoal pieces being dated are not contaminated with modern ${ }^{14} \mathrm{C}$, then the age of the host deposit (in which the charcoal sample is present) must be no older than the youngest piece of charcoal. For this thesis, the results of the 7 detrital charcoal consistency tests were plotted on a frequency distribution curve which showed that the mean age that a detrital charcoal sample is older than its host deposit is 324 years, with a standard deviation of 431 years. Assuming that the 7 tests accurately portray the average age 


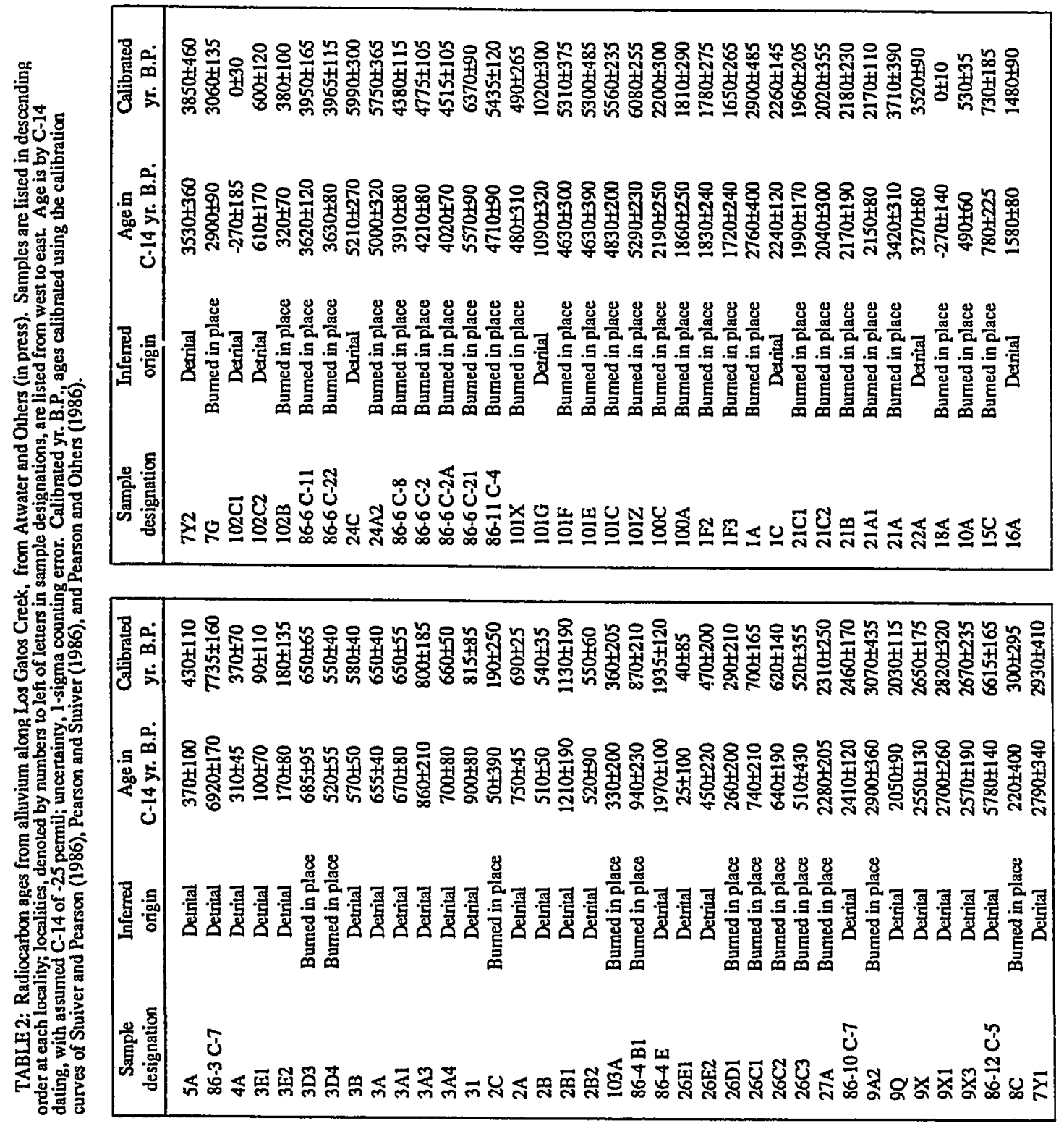


discrepancy between detrital charcoal and its host deposit, then 324 years should be subtracted from each detrital-charcoal age. This is not done for two reasons: (1) The data set involved in determining the correction value is too small (7 tests) to accurately portray the true population; and (2) the conclusions and inferences drawn in this study are not affected or changed when the correction is applied because the correction is so small.

Depositional rates of vertical accretion are, however, affected by the detrital charcoal age correction and are therefore given as two estimates: (1) Without any correction to detrital-charcoal ages; and (2) with a correction of 324 years applied to each detrital-charcoal age.

Depositional rate is defined as the rate of vertical accretion and is estimated as follows. At localities where two superposed charcoal deposits (from which calibrated ${ }^{14} \mathrm{C}$ dates are available) are present within deposits of uniform depositional facies, the difference in age is divided by the thickness (in millimeters) of sediment separating the charcoal deposits. If both the charcoal deposits are composed of burned-in-place charcoal (in situ) and there is no depositional hiatus between them, then the depositional rate is stated as such. If both the charcoal deposits are composed of burned-in-place charcoal and there is a depositional hiatus between the charcoal deposits (indicated by a buried soil), then the resulting depositional rate is a minimum because the hiatus indicates an imprecisely known length of time when no deposition occurred. If no hiatus is present between the charcoal deposits, and the lower charcoal deposit is composed of detrital charcoal and the upper deposit is composed of burned-in-place charcoal, then the depositional rate is a minimum. This is because the detrital charcoal can be older than its host deposit and could yield a length of time of deposition much too long. A second depositional rate is given calculated using a detrital charcoal age which has had 324 years subtracted from it in order to correct for a possibility that the detrital charcoal is older than its host deposit. If no hiatus is present between the charcoal deposits, and the lower charcoal deposit is composed of burned-in-place charcoal, and the upper deposit is composed of detrital charcoal, then the depositional rate is a maximum. If the detrital charcoal is older than its host deposit, then the calculated duration of deposition would be much too short. Here again, a second depositional rate is given using a corrected detrital charcoal age. Of 
course, uncertainties increase if dated deposits are composed of detrital charcoal or when a hiatus is present when the lower deposit is composed of burned-in-place charcoal and the upper deposit is composed of detrital charcoal. In these cases the depositional rate is stated as being approximate and a second depositional rate is given using corrected detrital charcoal ages.

\section{Correlations Among Measured Sections}

The stratigraphy of the deposits in Los Gatos Creek is divided into chronostratigraphic units and correlated among the measured sections.

"A chronostratigraphic unit is a body of rock established to serve as the material reference for all rocks formed during the same span of time. Each of its boundaries is synchronous. The body also serves as the basis for defining the specific interval of time, or geochronologic unit (Article 80), represented by the referent" (North American Commission on Stratigraphic Nomenclature, 1983). The units of the Los Gatos Creek deposits are defined principally by age, but unconformities and disconformities are used in each section to help define the contacts between units. A typical unconformity might be a channel cut into older deposits; a typical disconformity might be a hiatus defined by the top of an incipient soil.

The deposits in each unit are grouped according to their interpreted stratigraphic facies and interpreted depositional environments. In brief, two depositional environments have been defined: channel and overbank. In channel environments, sediment is deposited in the channel adjacent to, or in, the thalweg; in overbank environments, sediment is deposited on the floodplain beyond the banks of the creek. Therefore, oyerbank deposits may be deposited higher in elevation than their coeval channel deposits.

\section{Stratigraphy Of Chronostratigraphic Units}

Fills 1,2 , and 3 are defined as deposits from individual aggradational episodes in the creek's history that were not interrupted by any regional degradational episodes, but are separated from each other by episodes of incision. 
Figure 4 shows the units arranged according to stratigraphic succession and the associated radiocarbon dates. Figure 5 is a generalized geologic cross section (mean sea level as datum) showing facies relations (see figure 2 for location of cross section). For Fill 2, the base of each successively younger chronostratigraphic unit is found upstream of the preceding unit; these units are interpreted as the parts of a single aggradational episode during which the locus of deposition migrated upstream. Figure 6 is the same cross section as figure 5 but with the 1984 Los Gatos Creek thalweg as datum. The reason for choosing the thalweg as datum is so that the deviation of paleo-thalweg elevations from the 1984 thalweg elevation can be more clearly seen, thereby demonstrating the upstream migration of the locus of deposition for Fill 2. Table 3 is a listing of the channel facies deposits of Fill 2 that shows that the deposits become younger upstream. The exposures of Fill 1 are not as good as those for Fill 2, so it is unclear if the units of Fill 1 resulted from one or from two aggradational episodes. For Fill 3, there are not enough data to determine if its locus of deposition also migrated upstream.

Ten depositional rates were calculated for overbank facies deposits, 4 are calculated for channel facies deposits, and 1 is calculated for meander cut-off facies deposits (table 4). The average pooled mean of the depositional rate for overbank facies deposits is $2.84 \mathrm{~mm} / \mathrm{yr}$ (uncorrected for detrital age inconsistency) and 3.25 $\mathrm{mm} / \mathrm{yr}$ (corrected). The average pooled mean depositional rate for channel facies deposits is $16.45 \mathrm{~mm} / \mathrm{yr}$ (uncorrected) and $13.16 \mathrm{~mm} / \mathrm{yr}$ (corrected).

Fill 1

The first aggradation resulted in the deposits of Fill 1 (units A and B), began sometime before 7735 years ago and culminated shortly after 6615 years ago.

Unit A. This unit, the oldest strata exposed at Los Gatos Creek, is about 7735 years old. Exposed only at locality 86-3 near Coalinga, this unit is a 1.4meter-thick deposit of unlaminated silt which is interpreted as a floodplain deposit of the overbank facies (fig. 7). The depositional rate is unknown, and the upper contact is in erosional unconformity with unit $\mathrm{H}$. 


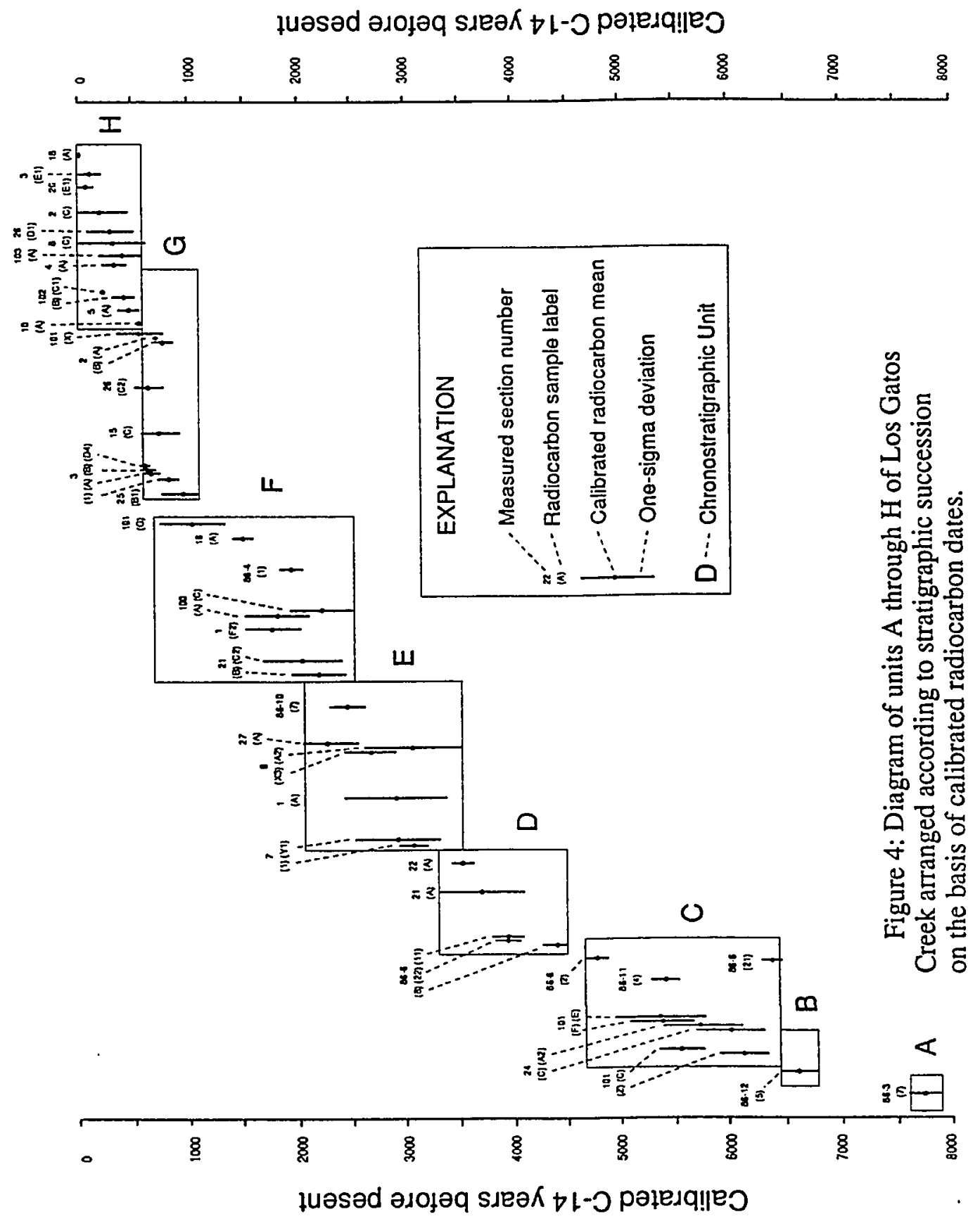




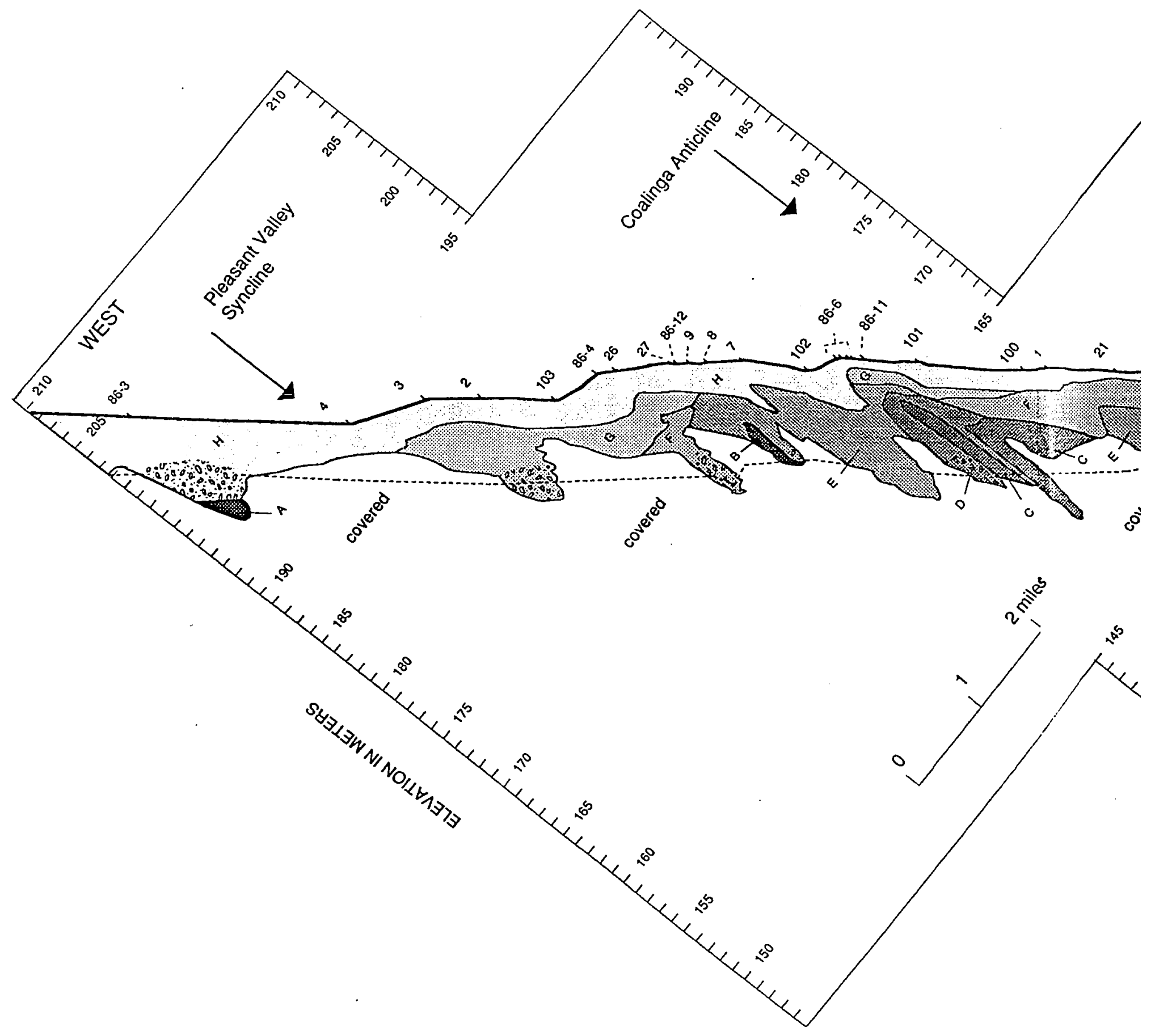




\section{$+$}




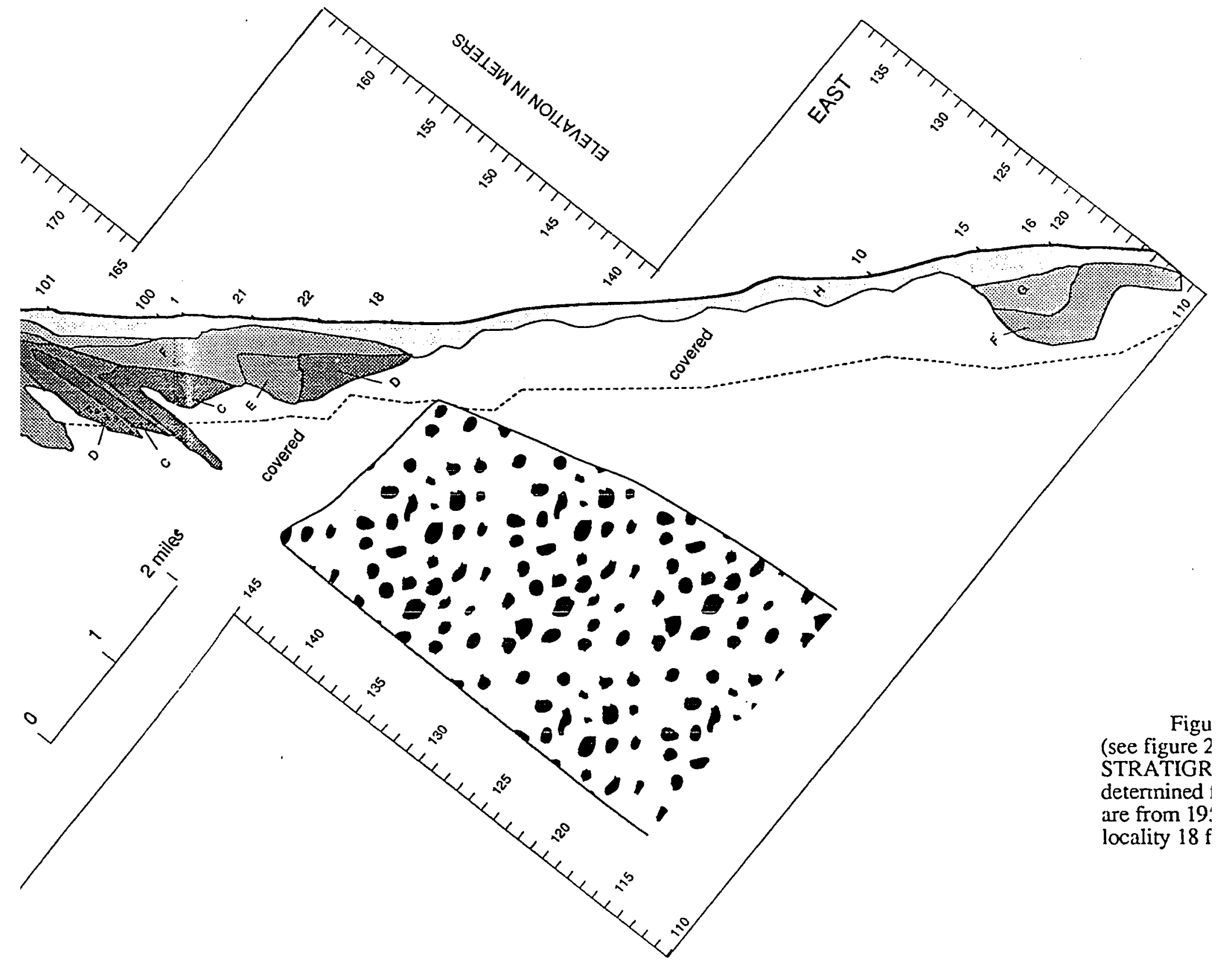


| 


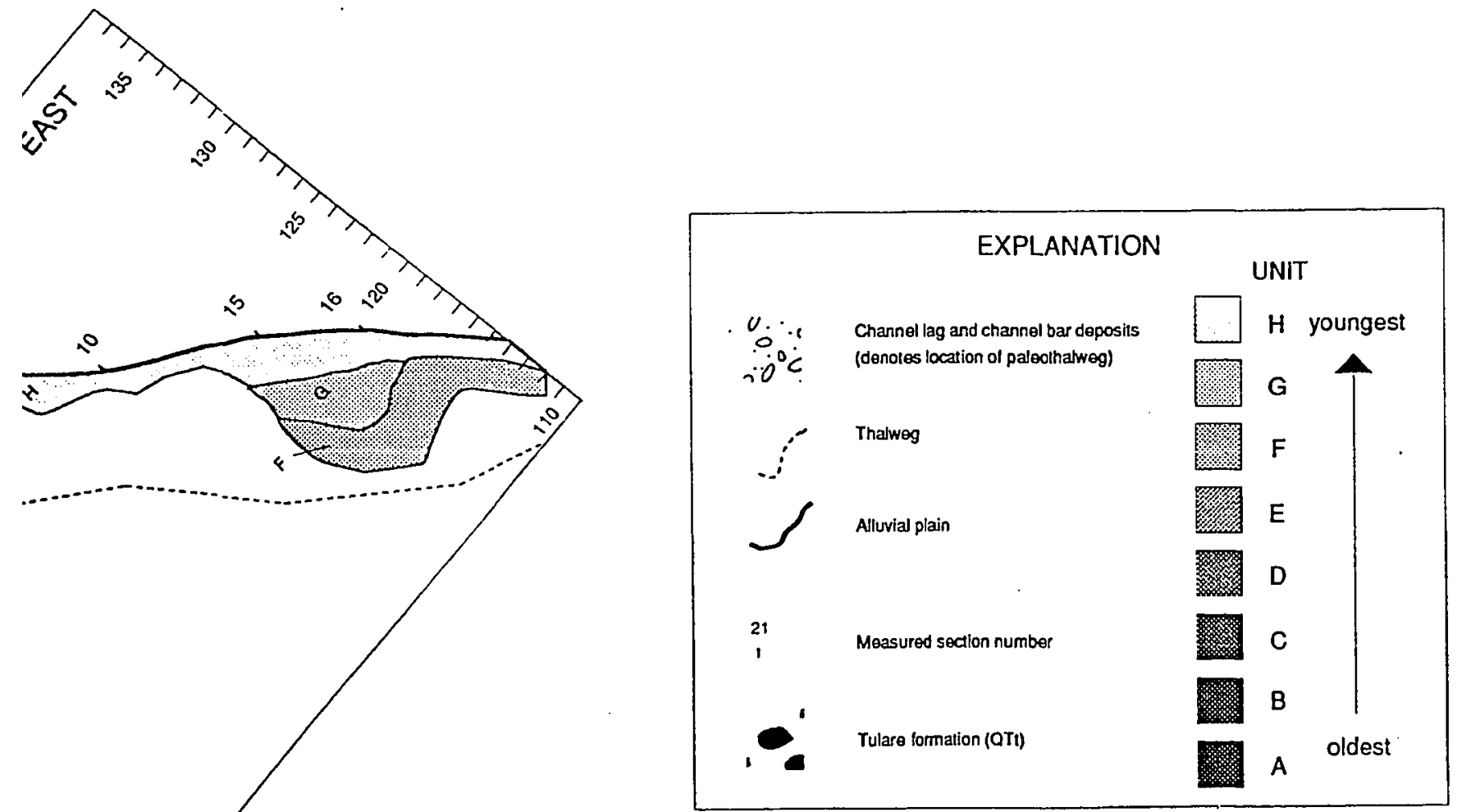

Figure 5: Cross section of deposits exposed in the banks of Los Gatos Creek (see figure 2 for location of cross section). Units are described in section titled STRATIGRAPHY. Thalweg and alluvial plain elevations west of locality 18 deternined from 1984 leveling survey. Alluvial plain elevations east of locality 18 are from 19567.5 minute Guijarral Hills Quadrangle. Thalweg elevations east of locality 18 found from measuring down from alluvial plain surface at measured sections. 


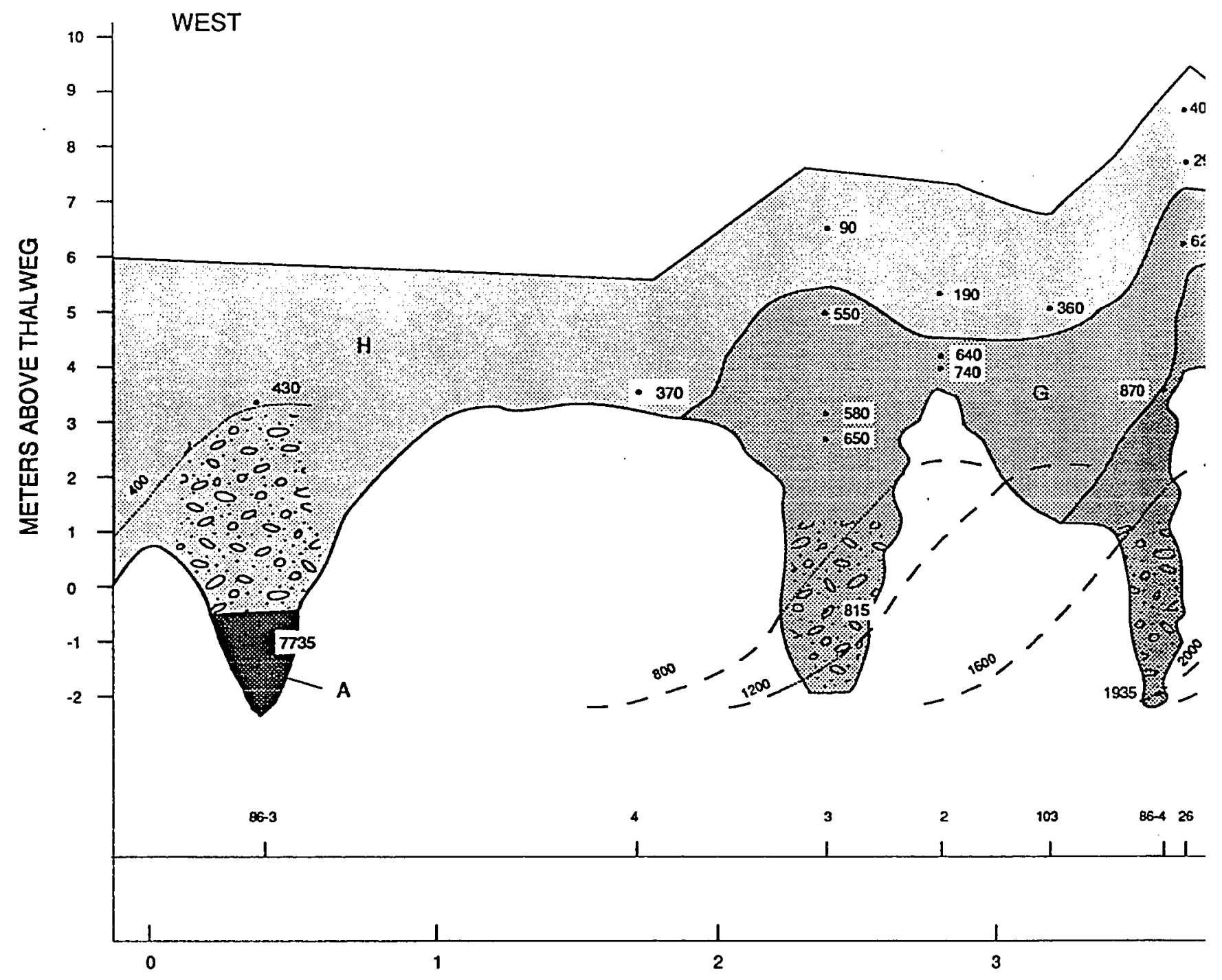




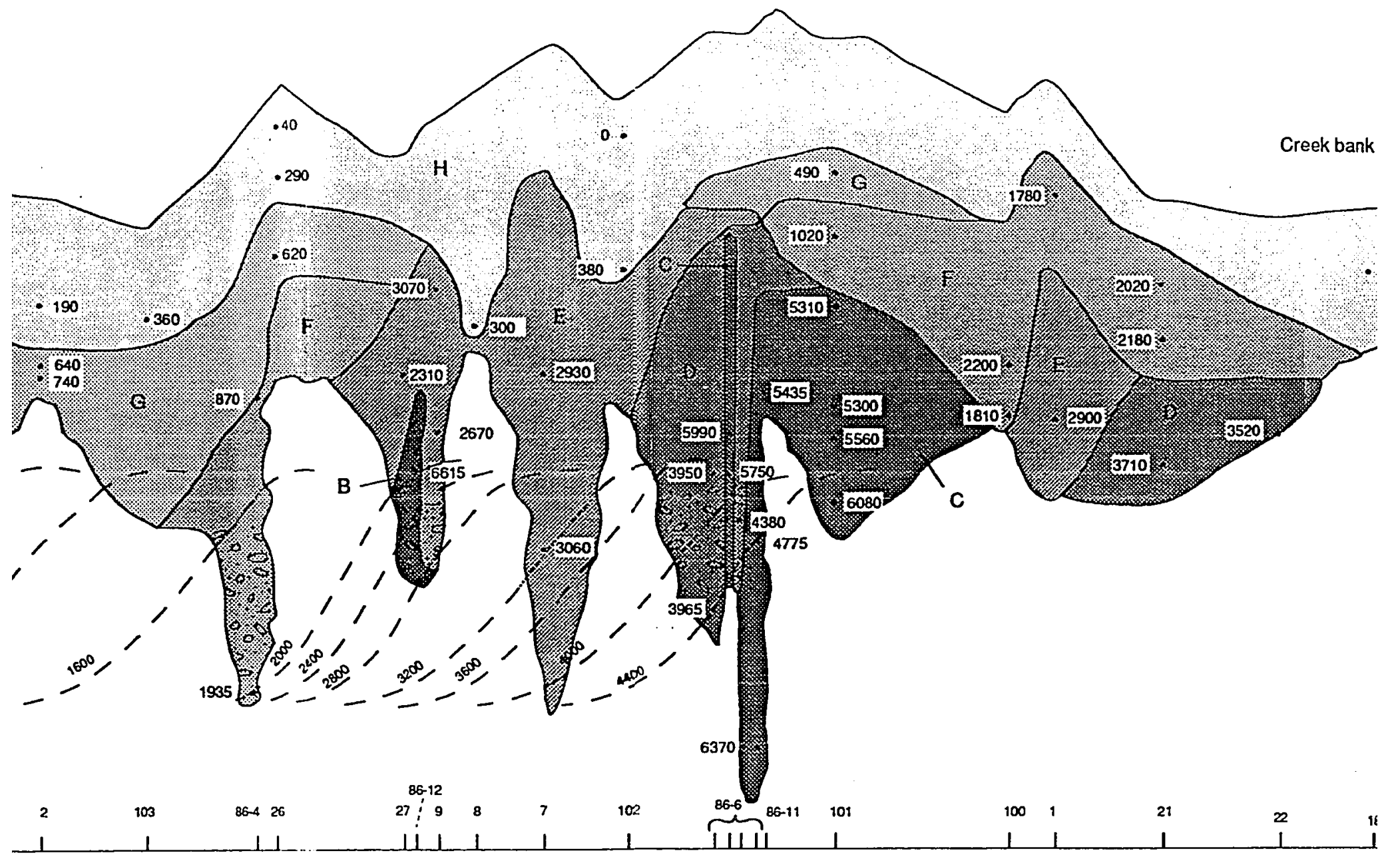

$\begin{array}{cccc}1 & 1 & 1 & 1 \\ 3 & 4 & 5 & 6 \\ & & & \text { MILES DOWNSTREAM OF HIGHWAY 198 BRIDGE CROSSING LOS GATOS C }\end{array}$

Figure 6: Same cross section as in figure 5, but using the 1984 tl The upstream migration of the depositional pulse that resulted in Fil deposits is illustrated as time lines drawn through channel facies deposits of similar age. 


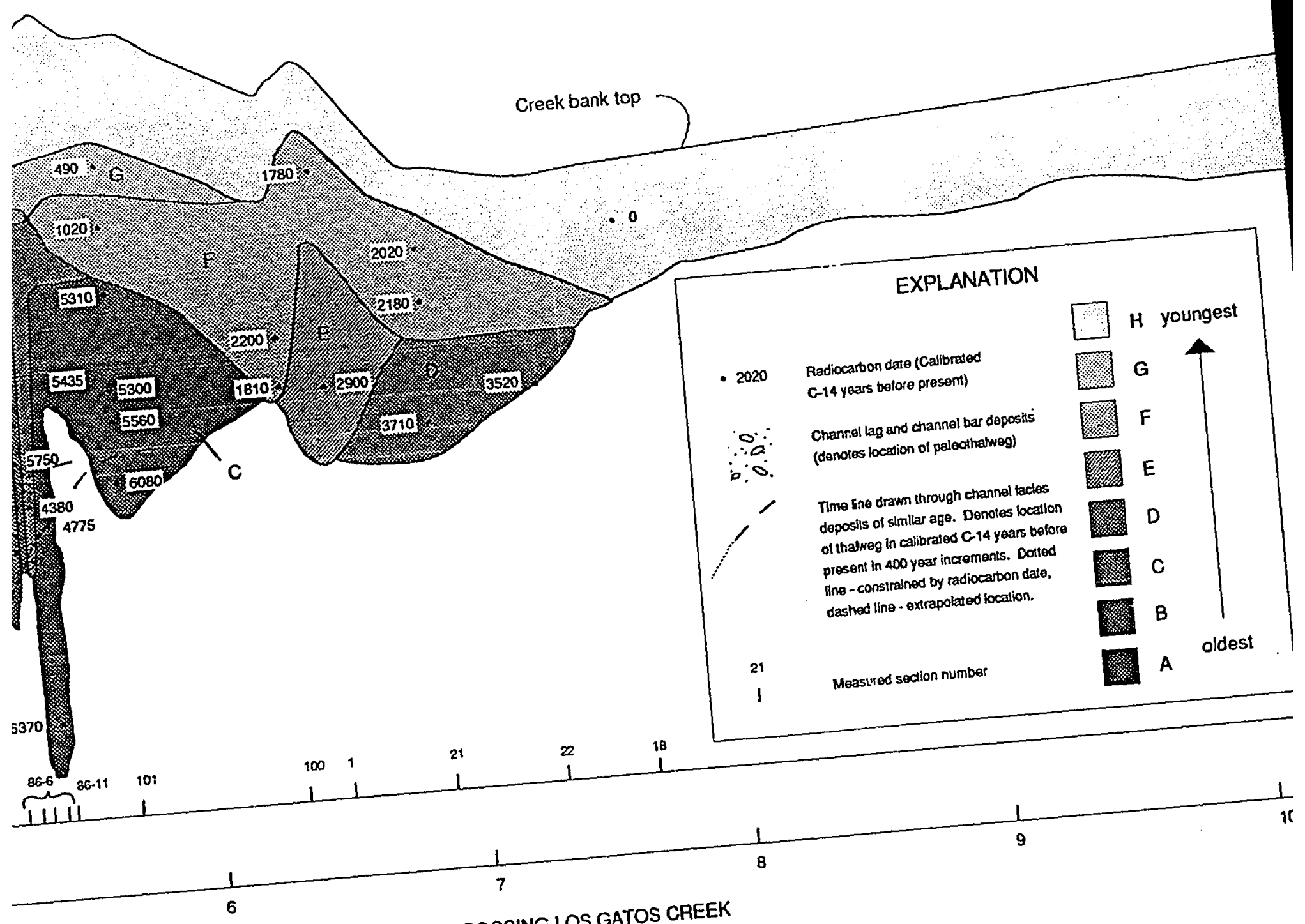

ALES DOWNSTREAM OF HIGHWAY 198 BRIDGE CROSSING

Figure 6: Same cross section as in figure 5, but using the 19 in Fill 2 he upstream migration of the depositional puls channel facies leposits is illustrated as
leposits of similar age. 


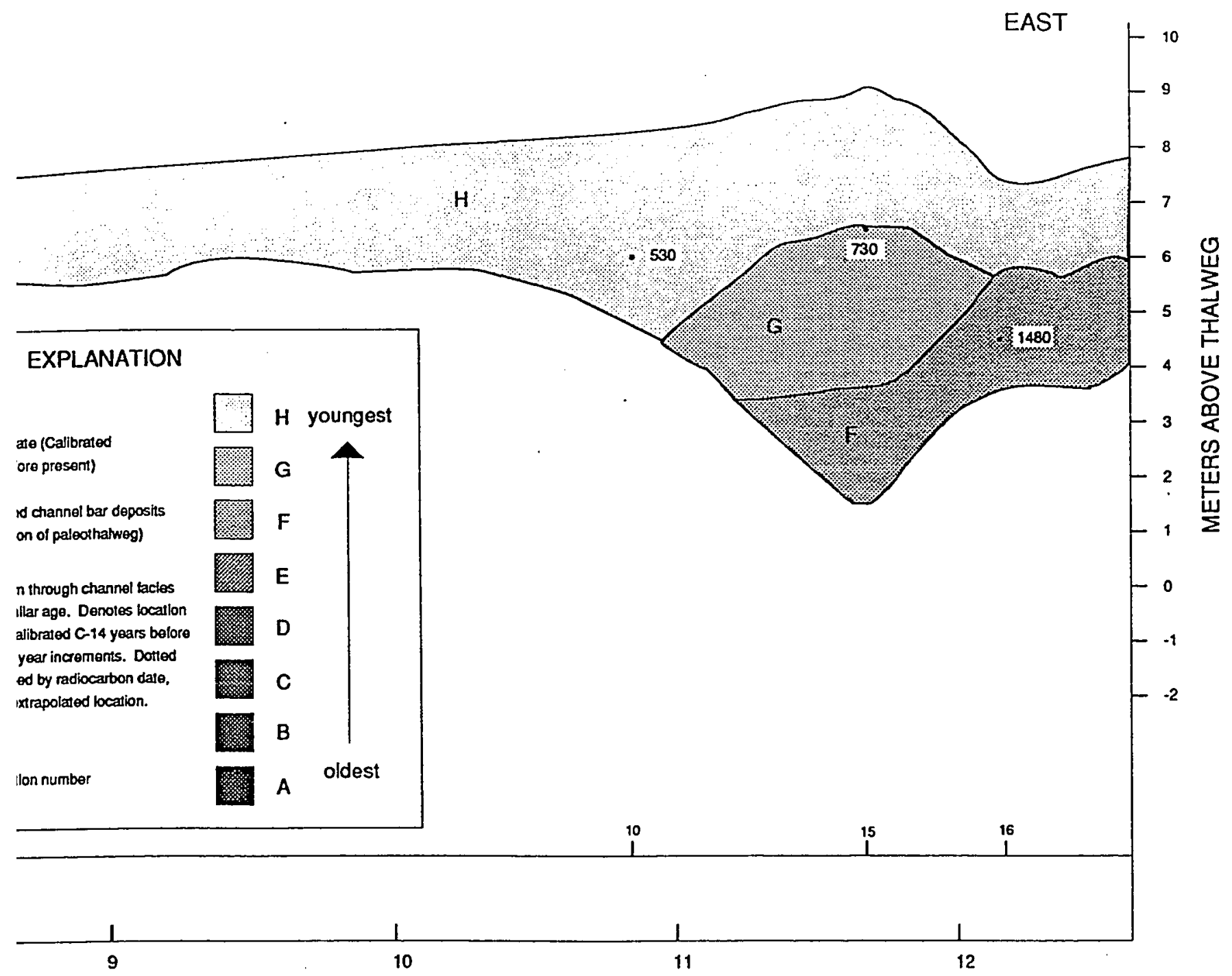


| 


\begin{tabular}{|c|c|c|c|c|c|c|}
\hline \multirow{6}{*}{ 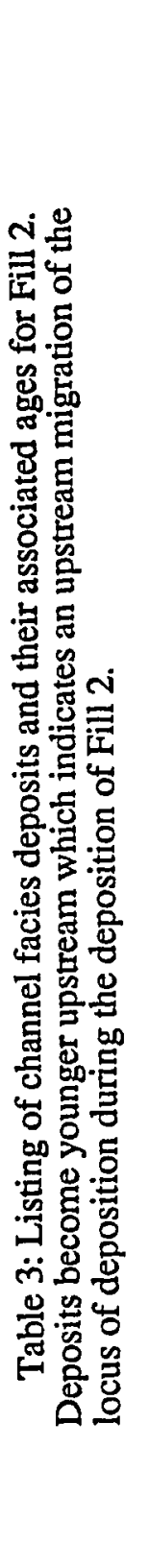 } & 0 & $\omega$ & ш & L & ర & $I$ \\
\hline & 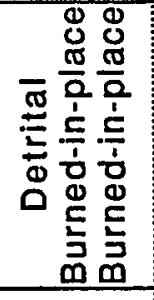 & 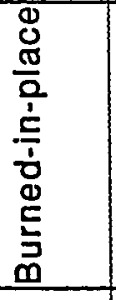 & 离 & 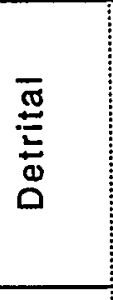 & 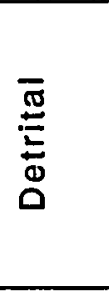 & 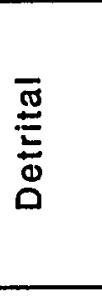 \\
\hline & 웅요 & $\begin{array}{l}L 0 \\
\infty \\
0\end{array}$ & Oे & $\underset{ְ}{\mathscr{\Xi}}$ & ஜొ & 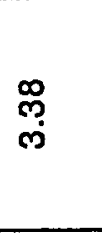 \\
\hline & 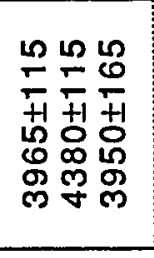 & $\begin{array}{l}\text { no } \\
\stackrel{m}{7} \\
+1 \\
0 \\
0 \\
0\end{array}$ & $\begin{array}{l}\text { N } \\
\text { N } \\
+1 \\
\stackrel{0}{0} \\
\stackrel{0}{N}\end{array}$ & 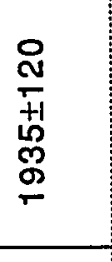 & $\begin{array}{l}1 \\
\infty \\
+1 \\
10 \\
\infty \\
\infty\end{array}$ & $\begin{array}{l}\frac{0}{2} \\
\frac{7}{+1} \\
0 \\
y\end{array}$ \\
\hline & 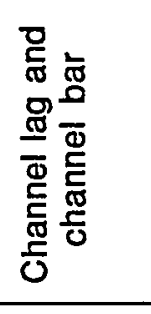 & 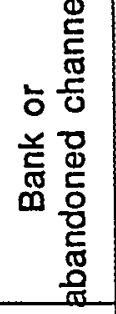 & 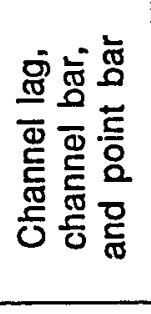 & 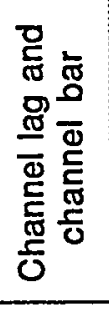 & 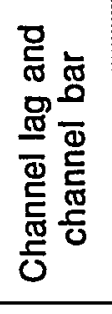 & 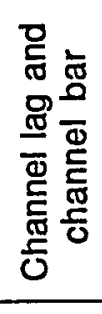 \\
\hline & m & $\stackrel{r}{\dot{q}}$ & $\stackrel{m}{\dot{q}}$ & $\stackrel{\mathscr{\rho}}{\dot{\rho}}$ & $\stackrel{े}{\mathbf{N}}$ & $\stackrel{+}{0}$ \\
\hline 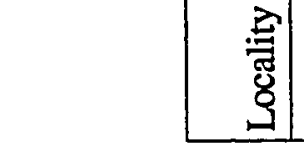 & $\begin{array}{l}0 \\
1 \\
\vdots \\
\infty\end{array}$ & $\boldsymbol{N}$ & $\sigma$ & $\begin{array}{l}\mathbf{y} \\
\dot{0} \\
0\end{array}$ & $m$ & $\begin{array}{l}0 \\
1 \\
0 \\
\infty\end{array}$ \\
\hline
\end{tabular}




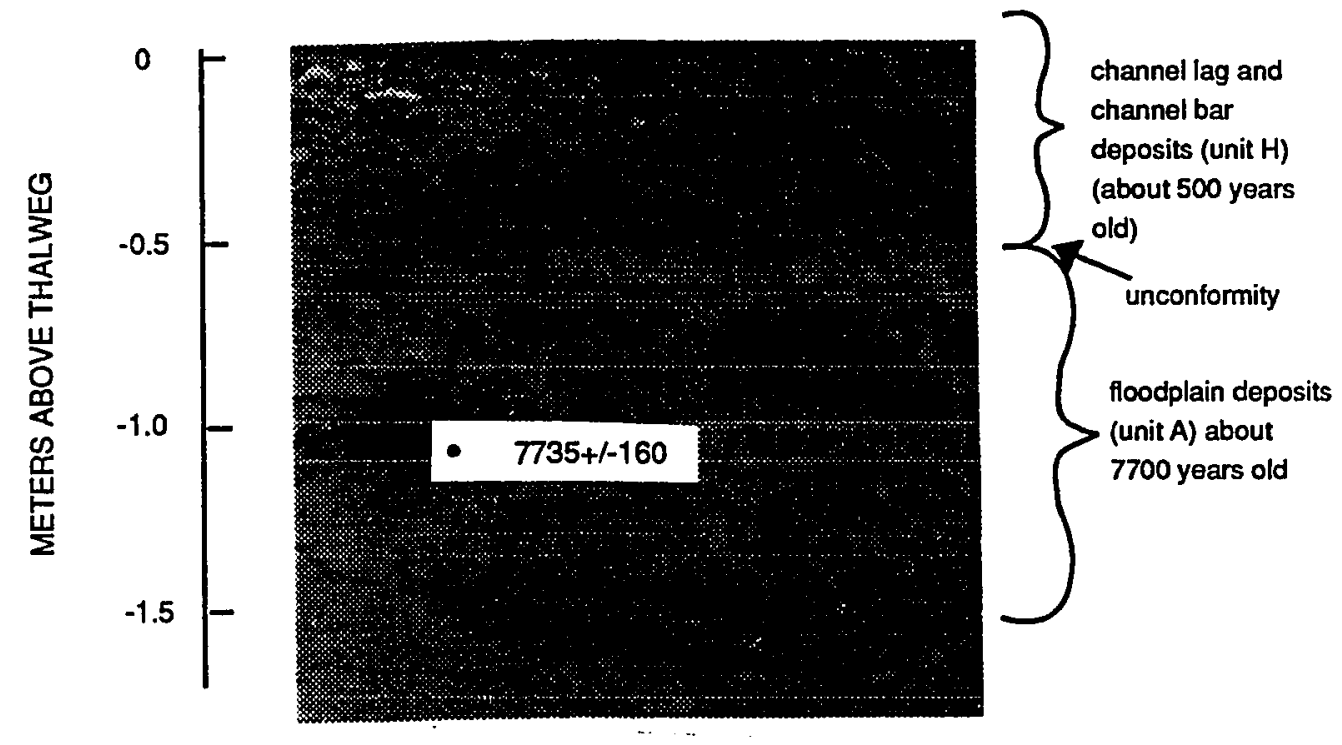

Figure 7: Laminated silt floodplain deposit, and location of radiocarbon dates of unit A overlain by channel lag and channel bar deposits of unit $\mathrm{H}$. Locality 86-3. 
Table 4: Depositional rates of vertical accretion in mm/yr for units C, D, E, F, $\mathrm{G}$, and $\mathrm{H}$, listed according to facies type. Depositional rates calculated using corrected detrital-charcoal ages are also given.

\begin{tabular}{|c|c|c|c|c|c|}
\hline \multicolumn{2}{|c|}{ Channel facies } & \multicolumn{2}{|c|}{ Overbank facies } & \multirow{2}{*}{$\begin{array}{l}\text { Meander Cut-off facies } \\
\text { Abandoned channel deposits }\end{array}$} & \multirow[t]{2}{*}{ Unit } \\
\hline $\begin{array}{l}\text { Channel lag deposits } \\
\text { Channel bar deposits }\end{array}$ & Bank deposits & Floodplain deposits & Crevasse Splay deposit & & \\
\hline & & & $\begin{array}{l}2.1 \pm 1.5(101) \\
2.4 \pm 1.2(101)\end{array}$ & $2.5 \pm 0.3(86-6)$ & C \\
\hline \multirow[t]{2}{*}{$80.0 \pm 76(86-6)$} & & & & & $D$ \\
\hline & $\begin{array}{l}24.2 \pm 19.5(7) \\
6.9 \pm 3.8\end{array}$ & & & & E \\
\hline $\begin{array}{l}14.0 \pm 3.4(86-4) \\
20.1 \pm 10.8\end{array}$ & & $6.5 \pm 5.1(21)$ & & & $F$ \\
\hline \multirow[t]{3}{*}{$\begin{array}{l}13.6 \pm 5.9(3) \\
13.6 \pm 11.5\end{array}$} & & $\begin{array}{l}2.1 \pm 1.1(101) \\
5.4 \pm 4.6 \\
4.2 \pm 2.2(26) \\
1.6 \pm 1.3(2) \\
1.6 \pm 1.5 \\
5.7 \pm 3.0(3) \\
5.7 \pm 5.1\end{array}$ & & & $\mathbf{G}$ \\
\hline & & $\begin{array}{l}2.3 \pm 0.7(2) \\
6.5 \pm 4.5 \\
4.0 \pm 2.0(26) \\
35.5 \pm 3.5 \\
3.5 \pm 1.7(3) \\
2.9 \pm 1.7\end{array}$ & & & H \\
\hline & & $\begin{array}{lr} & \text { EXPLAN } \\
& \Gamma \text { Measu } \\
\pm 0.7(2) & \text { Uncorre } \\
\pm 4.5 \quad \text { Corre }\end{array}$ & $\begin{array}{l}\text { VATION } \\
\text { ured section number } \\
\text { ected depostional rate } \\
\text { ectepositional rale }\end{array}$ & & \\
\hline
\end{tabular}


Unit B. This unit is exposed only at locality $86-12$, and is about 6615 years old. It is a 3.7-meter-thick deposit of trough cross bedded and planar cross bedded very coarse sand and gravelly very coarse sand, and is interpreted as gravel lag deposits and channel bar deposits of the channel facies. The depositional rate is unknown. The contact with unit $A$ is not exposed, but unit $E$ is cut into unit $B$ by 1.2 meters.

Fill 2 - Lower Part

Fill 2 (units C - H) began about 6400 years ago and culminated about 190 years ago. The subdivision of Fill 2 into lower and upper parts is made because of regional changes in the following characteristics of the fill: grain size, buried soils, and age. These changes probably reflect a sudden increase in aggradation rates for Fill 2.

The lower part of Fill 2 (units $C$ through $\mathrm{G}$ ) ranges in thickness from 0 to more than 13 meters, but the maximum thickness is unknown due to concealment by the present creek bed. This part of Fill 2 ranges from 500 years old to at least 6370 years old. Poorly developed buried soils are rather common in the lower part and often contain soft, probably pedogenic, $\mathrm{CaCO}_{3}$ nodules and show slight reddening of the alluvium from a light olive brown (Munsell color 2.5Y 5/4) to yellowish brown (hue 10YR). Although the lower part of Fill 2 is dominated by silt and fine sand deposits of the overbank facies, medium to coarse sand deposits of the channel facies are quite common, and pebble gravel is present nearly everywhere at the base of this fill. This gravel is interpreted as paleo stream courses.

Unit C. This unit is between 6370 and 3500 years old, and is found at localities $101,86-11,86-6$, and 24 . The total thickness is about 10.8 meters.

At locality 101 the unit consists of 4.4 meters of finely laminated clayey silt interbedded with 5 upward fining sequences of cross laminated medium sand to fine silt and clay (fig. 8). These are interpreted as overbank facies floodplain deposits and crevasse splay deposits, and range from 6080 to 5310 years old.

At localities 86-11 and 86-6 is an 8.2-meter-thick sequence of deposits of the meander cut-off facies that range from 6370 to 3500 years old. These deposits 
LINก

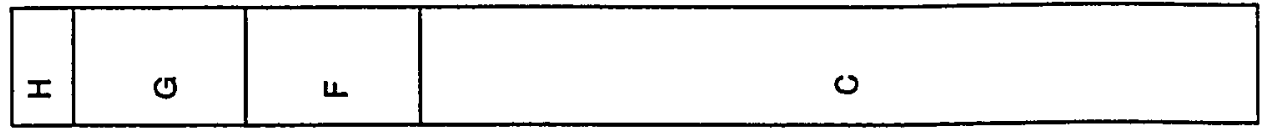

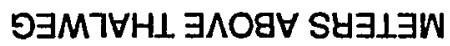

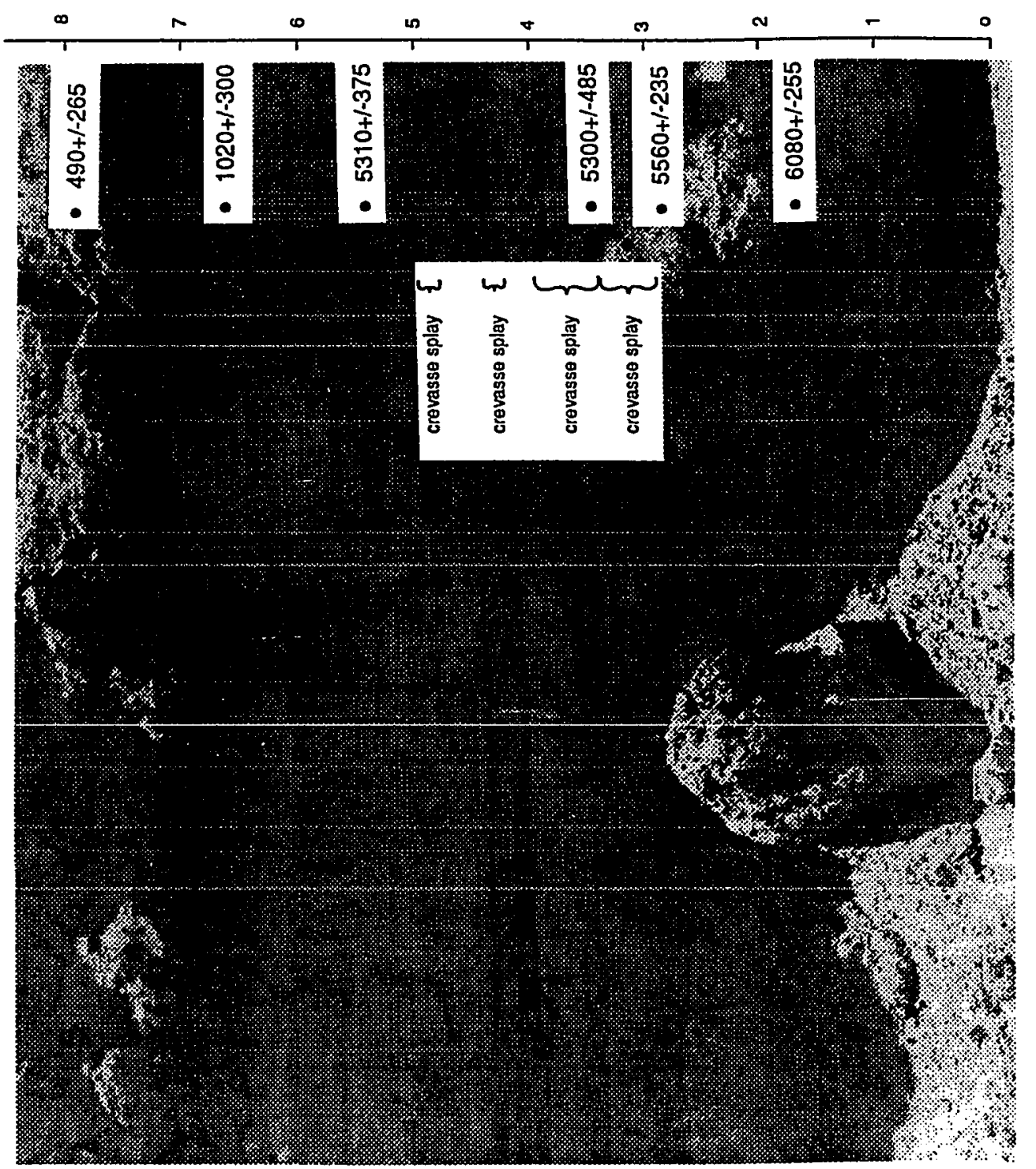

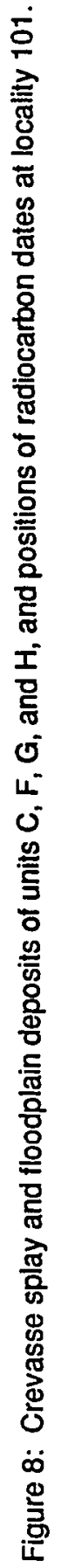


consist of finely laminated clayey silts with interbeds of fine sand and fill a channel cut into older deposits.

At locality 24 is a 6-meter-thick sequence of 10-30 centimeter thick upward fining deposits of cross bedded medium to fine sand to silt. These are about 5900 years old, and are interpreted as levee deposits of the overbank facies.

Depositional rates for the crevasse splay deposits at locality 101 are calculated using 4 superposed burned-in-place charcoal deposits. The depositional rate averages about $2.3 \pm 1.5$ millimeters per year. For the gully fill deposits at locality 86-6 two burned-in-place charcoal deposits bounding a possible hiatus yield a minimum depositional rate of $2.5 \pm 0.3 \mathrm{~mm} / \mathrm{yr}$ (table 4 ).

A degradational episode is assumed between the deposition of units $B$ and $C$ because the base of unit $C$ is at least 7.7 meters below the top of unit $B$. Also, the deposits filling the channel cut into older deposits at localities 86-11 and 86-6 indicate that incision occurred before the deposition of unit $\mathrm{C}$. Unit $\mathrm{C}$ interfingers with and is cut by unit $\mathrm{D}$ at locality 86-6. The cause of this cut is interpreted as channel migration during the deposition of unit $D$ and does not indicate that a degradational episode occurred between the deposition of units $\mathrm{C}$ and $\mathrm{D}$.

Unit $D$. Unit $D$ ranges from 4310 to 3520 years old, and is present at localities $22,21,24$, and $86-6$. The total thickness is about 8.2 meters.

At locality 22 it is a 3520-year-old, 1.2-meter-thick floodplain deposit of cross laminated silt and very fine to fine sand with one 10-centimeter-thick crevasse splay deposit of medium sand.

At locality 21 this unit is 2.5 meters thick, is 3710 years old and is, again, a floodplain and crevasse splay deposit. Here the deposit is mostly unlaminated silt with three beds of cross bedded very fine to medium sand.

At locality 24 is a 1 -meter-thick deposit of three upward fining sequences of fine to very fine sand to silt. Silt rip-up clasts are also present. This deposit is a continuation of the levee deposits of unit $\mathrm{C}$ at this locality.

At locality 86-6 this unit is about 7.5 meters thick and 170 meters wide, and is composed of gravel lag, channel bars, and bank deposits of the channel facies. Hummocky cross bedded and trough cross bedded medium to coarse sand and pebbly coarse sand, talus blocks, and discontinuous silt lenses are all common. 
However, the gravel lag and channel bar deposits are only 3.0 meters thick; the rest of the deposit is composed of bank and point bar deposits. The base of this channel fill is about 4000 years old.

The depositional rate for the channel fill at locality 86-6 is based on an upper burned-in-place charcoal deposit overlying a lower detrital charcoal deposit. These yield a minimum rate of $80.0 \pm 76.0 \mathrm{~mm} / \mathrm{yr}$. No other depositional rates are known for this unit.

Aggradation continued uninterrupted between the deposition of units $\mathrm{C}$ and D. The gully fill at locality 86-11 and 86-6 of unit $C$ spans the time from the beginning of deposition of unit $C$ to the end of deposition of unit $D$. The channel cuts into unit $C$ at locality $86-6$ can be explained by channel migration during the deposition of unit $D$.

Unit E. This unit ranges from 3060 to 2310 years before present and is present at localities $1,86-6,7,9,86-12$, and 27 . The total thickness is about 8.7 meters.

At locality 1 the unit is 4.4 meters thick and is 2900 years old. Here, the deposits are mostly floodplain deposits of laminated silty very fine sand and silt and contain one 10-centimeter-thick crevasse splay deposit of medium to fine sand.

At locality 86-6 unit $\mathrm{E}$ is a 6.2-meter-thick deposit of interbedded 40- to 60centimeter-thick beds of finely laminated silt and 20 to 40 centimeter thick beds of cross bedded fine sand. The deposit fills a 6.2-meter-deep channel that lies in conformable contact with the channel deposits of unit $\mathrm{D}$. This deposit is interpreted as a meander cut-off deposit that resulted when the creek abandoned its channel.

At locality 7 the deposits are 5.9 meters thick and are either bank or meander cut-off deposits. Interbedded fine to very fine sand and medium to coarse silt typify the deposits. They range in age from 3060 to 2930 years old and have a maximum depositional rate of $24.2 \pm 19.5 \mathrm{~mm} / \mathrm{yr}$. This depositional rate was calculated using a detrital charcoal deposit overlying a burned-in-place charcoal deposit. Using a corrected detrital charcoal age yields a depositional rate of $6.9 \pm$ $3.8 \mathrm{~mm} / \mathrm{yr}$. Because of this rather high depositional rate and because the deposits are located very low in the section (about the same height above thalweg as channel 
deposits of the same age at locality 9) the deposits are suspected to be bank or meander cut-off deposits.

At locality 9 this unit is 6 meters thick, and is about 3000 years old at the base. Here the unit is composed of 1.0 meters of cross bedded pebbly, medium to coarse sand at the base fining upward to 5.0 meters of beds of fine to very fine sand and silt. This deposit is interpreted as a gravel lag at the base, fining upward as either point bar or bank deposits, and topped off as floodplain deposits.

At locality 86-12 the unit is a 2.8-meter-thick floodplain deposit overlying the channel deposits of unit B. At locality 27 this unit is made up of 1.5 meters of interbedded medium to coarse silt and very fine sand overlain by 1.7 meters of silt. These are interpreted as levee deposits overiain by floodplain deposits. Here the age is 2310 years old.

The base of the gravel lag at the base of unit $\mathrm{E}$ (localities 7 and 9) is about the same age as the top of the gravel lag at the base of unit D (locality 86-6) but upstream of unit $D$. Therefore, the gravel lag of unit $E$ was interpreted as the younger equivalent of the gravel lag of unit $D$, which may indicate an upstream migration of the locus of deposition in the thalweg during the deposition of units $D$ and $\mathbf{E}$.

Unit F. This unit ranges from 2180 to 1020 years old and is exposed at localities $16,22,21,1,100,101$, and $86-4$. The total thickness is 10.2 meters. Overbank facies are present at all these localities, but channel facies are present only at locality 86-4.

At locality 1 the unit is 1.9 meters thick, is dominantly very fine sand and silt, and is 1780 years old. At locality 16 the unit is 1.1 meters thick and is 1480 years old. The lithology is mostly finely laminated silty floodplain deposits. At locality 22 the unit is 1.3 meters thick and is predominantly finely laminated and cross laminated silty and massive fine sandy floodplain deposits.

At locality 21 unit $F$ is 2.8 meters thick and is 2180 to 2020 years old. At the base is a 50-centimeter-thick bed of cross bedded medium to fine sand with silt partings that is incised into unit $D$ by 40 centimeters. This is interpreted as a crevasse splay deposit. Above this is a 2.5-meter-thick deposit of laminated and cross laminated silt interrupted with a 35-centimeter-thick deposit of cross bedded 
pebbly very fine sand. This is interpreted as a floodplain deposit interbedded with a crevasse splay deposit.

At locality 100 the unit is 3.8 meters thick and is about 2000 years old. The deposits are mostly 20 - to 30 -centimeter-thick beds of laminated and cross laminated silt and sandy silt with one lenticular 10-centimeter-thick bed of fine to medium sand (fig. 9). These are interpreted as floodplain deposits and one crevasse splay deposit.

The floodplain deposits at locality 101 are 1.6 meters thick, are 1020 years old, and are composed of three upward fining sequences of fine sand to silty sand to silt.

At locality $86-4$ the unit is 5.5 meters thick and is 1935 years old at the base. The deposits range from 3.3 meters of gravel lag and channel bar deposits of the channel facies at the base to 2.2 meters of bank deposits, and floodplain deposits at the top. The gravel lags and channel bars are mostly 10- to 40centimeter-thick lenticular beds of unlaminated gravel and pebbly coarse sand and steeply cross bedded fine to coarse sand deposits (fig. 10). The overlying bank and floodplain deposits are mostly 25 - to 100 -centimeter-thick beds of planar cross bedded medium to coarse sand and laminated sandy silt.

The depositional rate for the overbank facies deposits at locality 21 are calculated using two superposed burned-in-place charcoal deposits and yield a rate of $6.5 \pm 5.1 \mathrm{~mm} / \mathrm{yr}$. The depositional rate for the channel facies deposits at locality 86-4 are calculated using a burned-in-place charcoal deposit over a detrital charcoal deposit and yield a minimum rate of $14.0 \pm 3.4 \mathrm{~mm} / \mathrm{yr}$. The depositional rate using a corrected detrital charcoal age is $20.1 \pm 10.8 \mathrm{~mm} / \mathrm{yr}$.

The base of the channel lag deposits at the base of unit $F$ at locality 86-4 are about 2200 years old and are about the same age as the top of the gravel lag deposits at the base of unit $E$ at locality 9 (fig. 6). The gravel lag deposits of unit $F$ are interpreted as the upstream equivalent of the gravel lag deposits of unit $E$ which indicates an upstream migration of the locus of deposition between these two localities about 2200 years ago.

Unit G. This unit is 870 to 490 years old, is 7.4 meters thick, and is exposed at localities $15,101,26,86-4,103,2$, and 3 . Overbank facies are present 


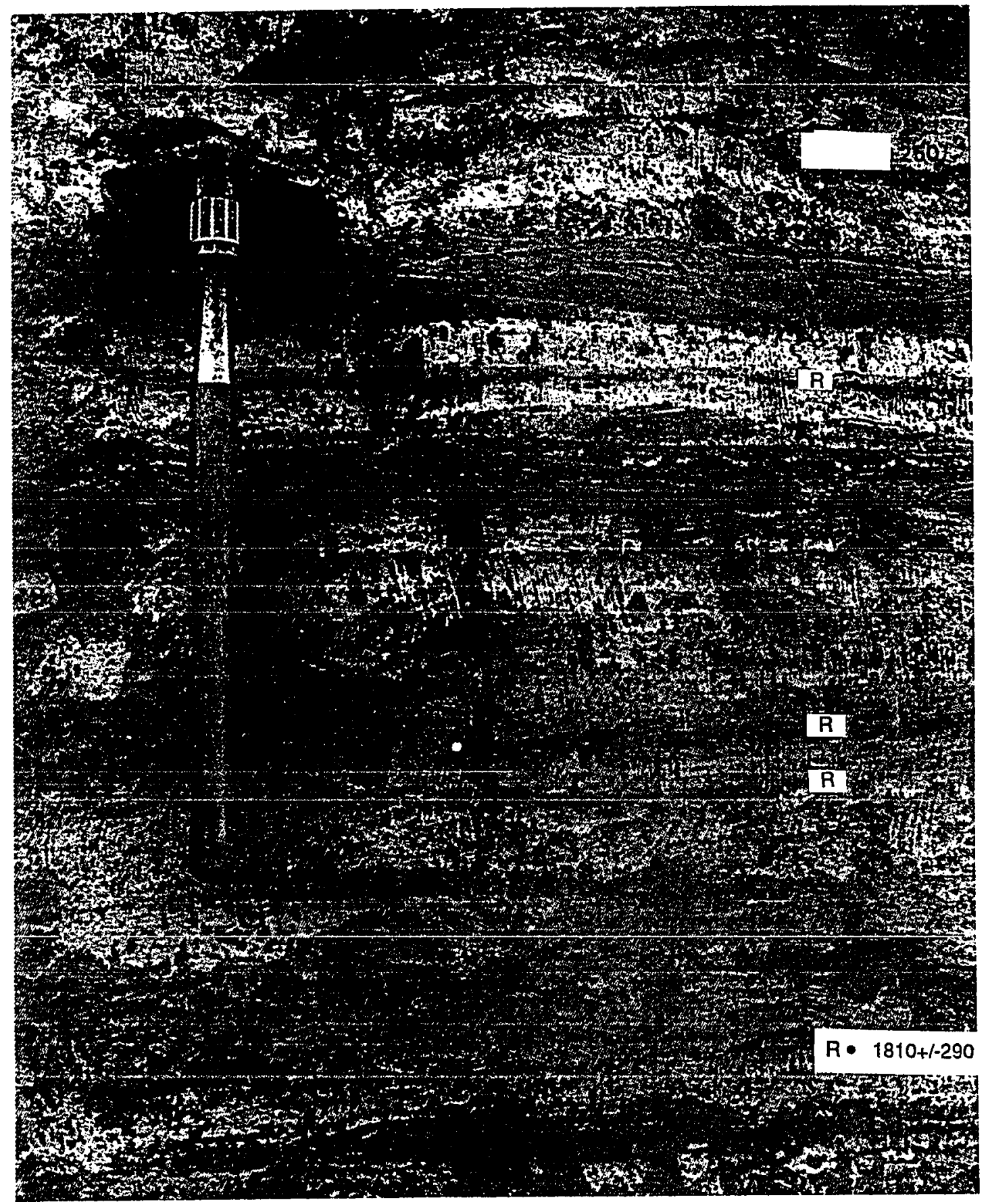

Figure 9: Laminated silt and fine sand floodplain deposits of unit $F$ showing localities of radiocarbon dates and 5 reddish layers $(R)$ interpreted as thermal oxidation from brush fires (from Atwater and others, in press). Locality 100. 


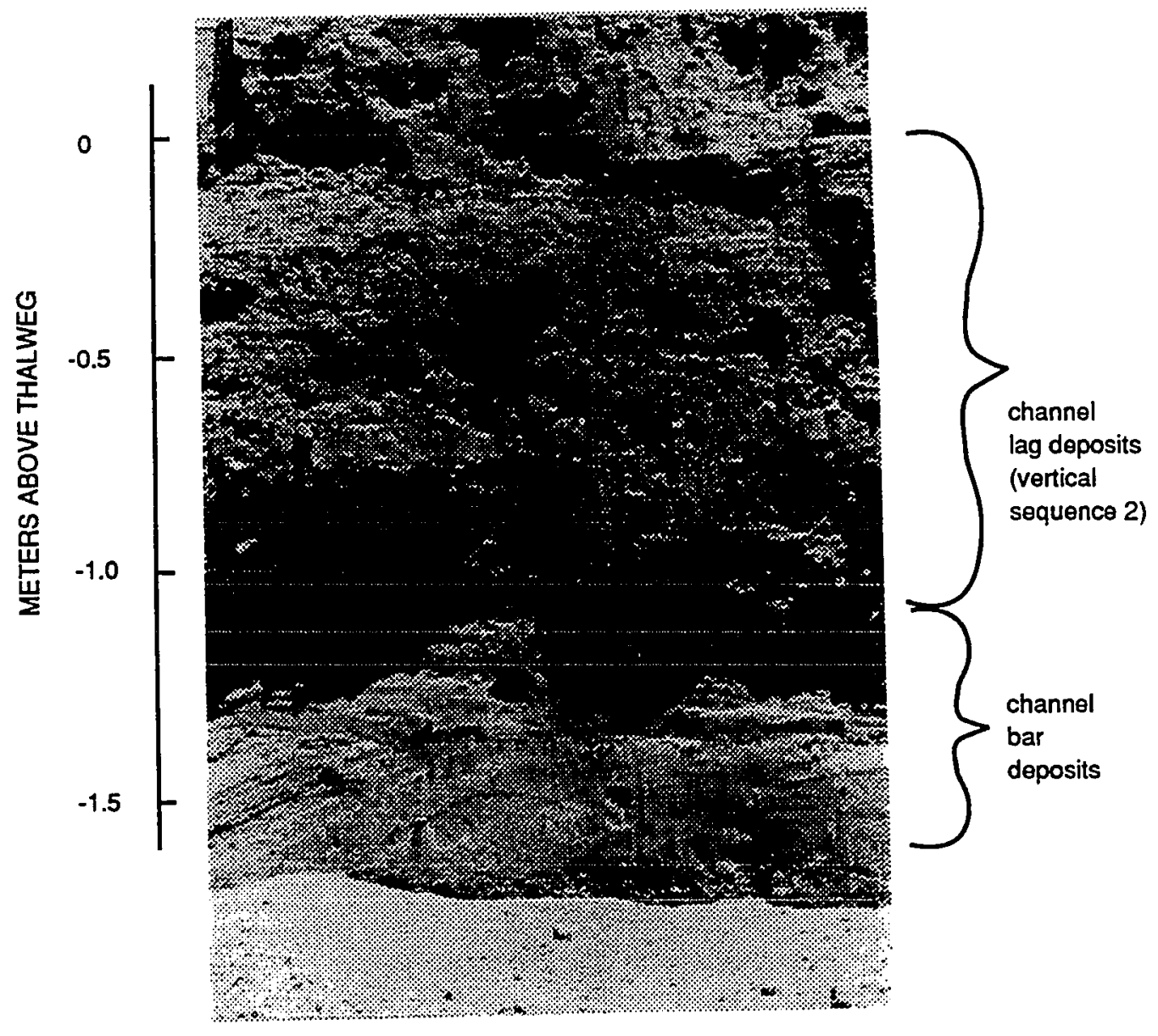

Figure 10: Channel lag and channel bar deposits of unit $F$ at locality 86-4. View within section is -1.5 to 0 meters above thalweg. 
at every locality, but channel facies are present only at locality 3.

At locality 15 unit $\mathrm{G}$ is 2.8 meters thick and is 730 years old near the top of the deposit. It is composed of 0.3- to 1.2-meter-thick beds of laminated and unlaminated silt and fine sand deposits and a 0.5 -meter-thick bed of cross bedded medium to fine sand. These are interpreted as floodplain and crevasse splay deposits.

At locality 101 the unit is a 1.0-meter-thick floodplain deposit composed of 20 centimeters of silty sand and 80 centimeters of clayey silt and is 490 years old.

At locality 26 it is 1.8 meters thick and is 620 years old. Here, the deposits are mostly cross bedded fine to very fine sandy and laminated silty floodplain deposits. At locality 86-4 the unit is 2.6 meters thick, is composed of interbedded 20- to 40-centimeter-thick beds of silty and fine sandy floodplain deposits, and is 870 years old at the base.

At locality 103 it is a 3.1-meter-thick sequence of floodplain and crevasse splay deposits. The sequence consists of 3 deposits 10 to 60 centimeters thick of cross bedded medium to coarse sand; these are interpreted as crevasse splay deposits. The floodplain deposits are 40 - to 80 -centimeter-thick beds of laminated silt and fine sand.

At locality 2 the floodplain deposits are 1.0 meter thick, are 740 to 690 years old, and are composed of interbedded fine sand and silt.

At locality 3 unit $G$ is 7.4 meters thick and ranges from 815 to 550 years old. The lower 3.2 meters are mostly medium to coarse sand deposits with 3 gravel layers and one 30-centimeter-thick silt deposit. These are interpreted as gravel lag and channel bar deposits. The upper 4.2 meters is mostly interbedded laminated and cross laminated very fine sand and silt with one 5-centimeter-thick bed of medium sand. These deposits are interpreted as mostly bank and floodplain deposits with one crevasse splay deposit.

The depositional rate for the channel deposits at locality 3 is calculated using two superposed detrital charcoal deposits and yields a rate of about $13.6 \pm 5.9$ $\mathrm{mm} / \mathrm{yr}$. The depositional rate using corrected detrital charcoal ages is $13.6 \pm 11.5$ $\mathrm{mm} / \mathrm{yr}$. The depositional rate for the floodplain deposits at locality 101 are calculated using a burned-in-place charcoal deposit located above a detrital charcoal deposit and yield a minimum rate of $2.1 \pm 1.1 \mathrm{~mm} / \mathrm{yr}$. The corrected depositional 
rate is $5.4 \pm 4.6 \mathrm{~mm} / \mathrm{yr}$. The floodplain deposits at locality 26 are calculated using two superposed burned-in-place charcoal deposits with a hiatus between them and yield a minimum depositional rate of $4.2 \pm 2.2 \mathrm{~mm} / \mathrm{yr}$. The floodplain deposits at locality 2 are calculated using two superposed detrital charcoal deposits and yield a rate of about $1.6 \pm 1.3 \mathrm{~mm} / \mathrm{yr}$. The corrected depositional rate is $1.6 \pm 1.5 \mathrm{~mm} / \mathrm{yr}$. At locality 3 the depositional rate for the bank and floodplain deposits are calculated using two superposed detrital charcoal deposits and yields a rate of about $5.7 \pm 3.0$ $\mathrm{mm} / \mathrm{yr}$. The corrected depositional rate is $5.7 \pm 5.1 \mathrm{~mm} / \mathrm{yr}$.

The base of the gravel lag deposits at the base of unit $\mathrm{G}$ at locality 3 is about 1600 years old and is the same age as the top of the gravel lag deposits at the base of unit $\mathrm{F}$ at locality 86-4 (fig. 6). Therefore, the gravel lag deposits at locality 3 are interpreted as the upstream equivalent of the gravel lag deposits at locality 86-4.

\section{Fill 2 - Upper Part}

The upper part of Fill 2 (unit $\mathrm{H}$ ) ranges in thickness from 0 to 4 meters, and fines upward from a medium to coarse sand at the base to silt and fine sand at the top. Buried soils in the upper part of Fill 2 lack the soft $\mathrm{CaCO}_{3}$ nodules and the reddening of the alluvium which are common in the lower part of the fill. The oldest radiocarbon age within the upper part of Fill 2 indicates a likely maximum age of about 500 years. The contact between the upper and lower parts of Fill 2 is mostly planar and conformable except for local disconformities where channels have been cut into the lower part. These channels can be seen at localities 8 , and 102 (figures 5 and 6).

Unit $\mathrm{H}$. Unit $\mathrm{H}$ is $\mathbf{5 3 0}$ to 40 years old and is exposed at every locality. Overbank facies are present everywhere but channel facies are found only at locality 86-3. At this locality the unit attains its maximum thickness of 6.3 meters and is composed of 3.5 meters of alternating channel lag and channel bar deposits at the base and 2.8 meters of bank and floodplain deposits at the top (figures 7 and 11). The gravel lag deposits are lenticular beds of gravelly coarse sand with clasts up to 30 centimeters in diameter and the channel bar deposits are lenticular and tabular beds of cross bedded medium to coarse sand and pebbly coarse sand. The top of 
Unit
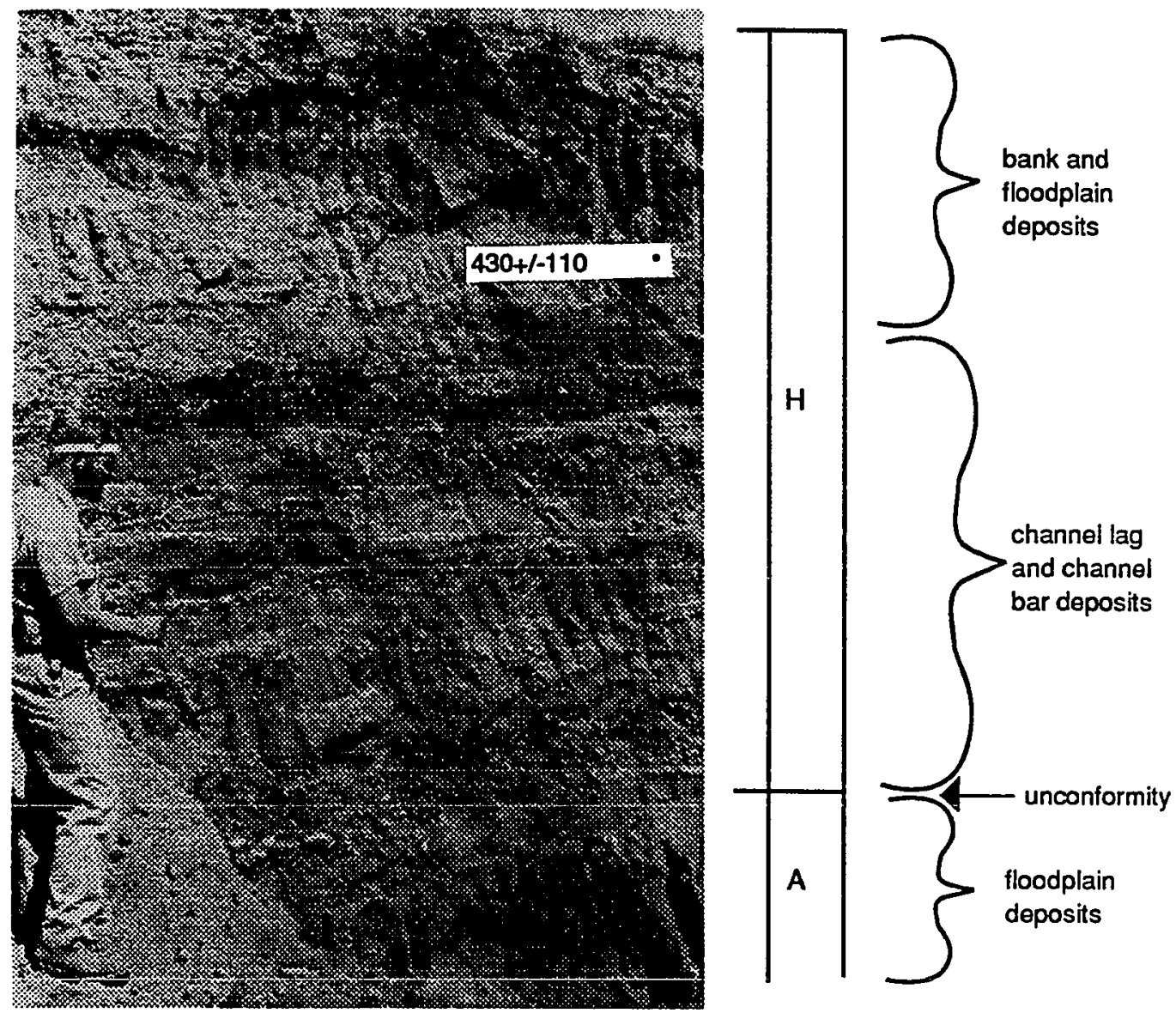

Figure 11: Channel lag, channel bar, bank, and floodplain deposits of unit $\mathrm{H}$ and overlying floodplain deposit of unit A at locality 86-3. John Tinsley for scale. 
these deposits is 430 years old. The overlying bank and floodplain deposits are composed of massive sandy silt. At several localities $(15,22,21,102$, and 3$)$ unit $\mathrm{H}$ is a cross bedded coarse to very coarse sand, sometimes with scattered pebbles. The deposits at these localities are interpreted as channel deposits deposited in small gullies adjacent to Los Gatos Creek, much like the present-day gullies near locality 3. Three of these localities $(22,21,102)$ are located near drainages that spill into Los Gatos Creek; during flood, discharge from the combined drainages might cause coarser sediment to overtop the creeks' banks at these localities. At locality 8 this unit is a 4.5-meter-thick, 4.0-meter-wide gully-fill deposit of the meander cut-off facies. The fill cuts 3.4 meters into older deposits and is composed mostly of well laminated silt. It is 300 years old at the base. At all other localities unit $\mathrm{H}$ is an overbank floodplain deposit. The base is typically a cross bedded (ripple-drift) medium to fine sand fining upward to laminated and massive silty sand and sandy silt.

Depositional rates for the floodplain deposits of unit $\mathrm{H}$ are calculated at localities 2, 26, and 3. At locality 2, a burned-in-place charcoal deposit overlies a detrital charcoal deposit yielding a minimum rate of $2.3 \pm 0.7 \mathrm{~mm} / \mathrm{yr}$. The corrected depositional rate is $6.5 \pm 4.5 \mathrm{~mm} / \mathrm{yr}$. At locality 26 , a detrital charcoal deposit overlies a burned-in-place charcoal deposit yielding a maximum rate of 4.0 $\pm 2.0 \mathrm{~mm} / \mathrm{yr}$. The corrected depositional rate is $3.5 \pm 3.5 \mathrm{~mm} / \mathrm{yr}$. At locality 3 , a detrital charcoal deposit overlies a burned-in-place charcoal deposit yielding a maximum rate of $3.5 \pm 1.7 \mathrm{~mm} / \mathrm{yr}$. The corrected depositional rate is $2.9 \pm 1.7$ $\mathrm{mm} / \mathrm{yr}$.

The base of the channel facies deposits at the base of unit $\mathrm{H}$ at locality 86-3 is about 800 years old and is the same age as the top of the channel facies deposits at the base of unit $G$ at locality 3 (fig. 6). Therefore, the channel facies deposits of unit $\mathrm{H}$ are interpreted as the upstream equivalent of the channel facies deposits of unit $\mathrm{G}$ and indicate an upstream migration of the locus of deposition in the thalweg 800 years ago.

Because of the unusual coarseness of the overbank deposits of unit $\mathrm{H}$ and its presence in every section, the deposition of this unit marks a change in the vigor of aggradation in the history of Los Gatos Creek. 
Fill 3

Aggradation 3 resulting in the deposits of Fill 3 began sometime after the year 1853 and probably stopped about 1955 . The deposits from this fill comprise the numerous cut terraces located immediately adjacent to the thalweg. The deposits of Los Gatos Creek not only contain Fills 1, 2, and 3 but also contain numerous cut terraces at various elevations above the thalweg that are inset against Fill 1 and Fill 2 deposits.

Unit I. This unit is 97 to 0 years old (zero Cal B.P. years old is actually the calendar year 1950) and perhaps even as young as present-day deposits (if deposition is occurring today in Los Gatos Creek). It is found everywhere alongside the present thalweg as cut terraces inset against the creeks banks. The terraces immediately adjacent to the thalweg range from 1.5 to 2.0 meters in height (fig. 12). Because of their close proximity to the thalweg, they are probably the most recent deposits along Los Gatos Creek.

Other, probably older, cut terraces are present nearly everywhere along the creek at various elevations above the thalweg and possibly have a different origin and age than the unit I terraces of Fill 3. They are always found inset against Fill 1 and Fill 2 deposits. The age of these terraces is unknown.

The Fill 3 terrace lithologies range from trough and planar cross bedded very coarse sand and gravelly coarse sand deposits at some localities, to finely laminated silty sand and sandy silt at other localities (fig. 13). Because they are proximal to the thalweg and exhibit coarse textures, the deposits of Fill 3 are interpreted as channel facies deposits (gravel lag, channel bar, point bar, and bank deposits).

The only aggradation rate calculated for unit $I$ is in the vicinity of locality 12 and is about 50 to $66 \mathrm{~mm} / \mathrm{yr}$. This impressively high deposition rate (compared to other rates for the Los Gatos Creek deposits) is calculated using the change in elevation of the creek's thalweg from that indicated on the 19567.5 minute Guijarral Hills Quadrangle (the topographic map has a contour interval of 5 feet and so the measurement of the thalweg has an uncertainty of \pm 1.5 feet or \pm 0.75 meters) and that measured in an 1853-54 township-subdivision survey. The difference in elevation of the thalweg between these 97-98 years is 4.9 to 6.4 


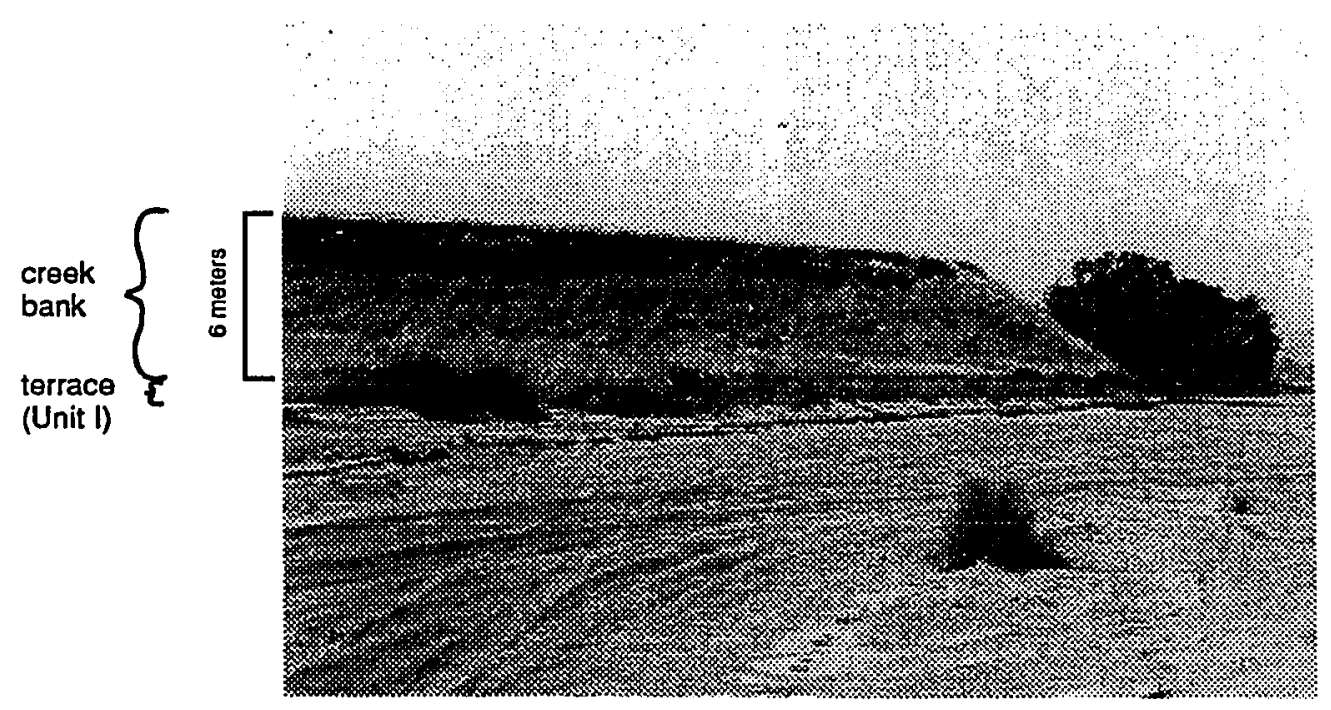

Figure 12: Two meter high terrace deposit of unit I on the south bank of Los Gatos Creek near locality 86-4. View from the thalweg.
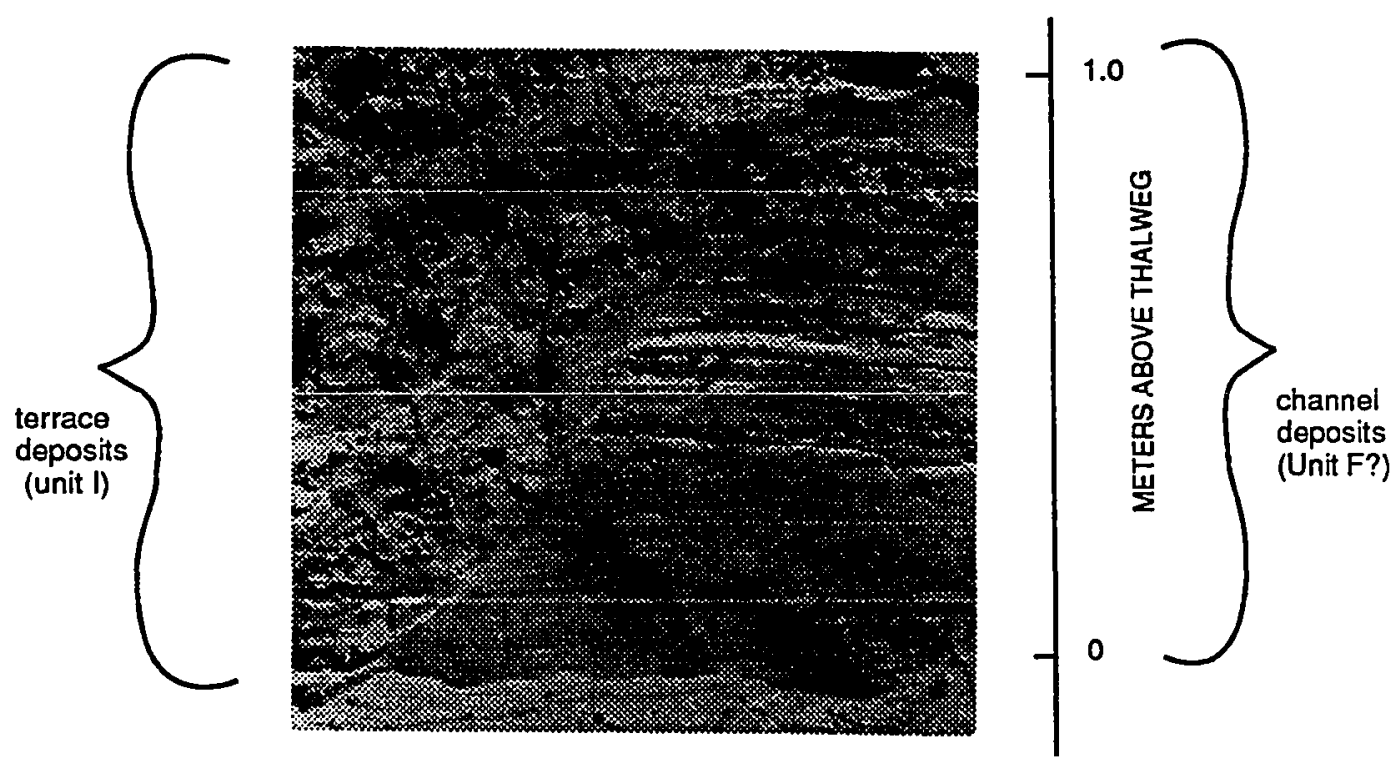

Figure 13: Stratigraphy of terrace in figure 12 exposed in backhoe-cut trench wall. The terrace deposits nearest the cut bank are probably bank deposits and contain slump blocks from the older material. 
meters which yields an apparent aggradational rate of 50 to $66 \mathrm{~mm} / \mathrm{yr}$.

The apparent youth of unit $I$ is assumed because of the following reasons: (1) As explained in the previous paragraph, the 1956 topographic map shows the elevation of the thalweg 4.9 to 6.4 meters above that measured in an 1853-54 township-subdivision survey. Subsequent incision has exposed all but the lower 3 meters of this deposit. Therefore, the deposits that are exposed were deposited after the years 1853-54. (2) Old bottles, cans, and other refuse of our civilization are sometimes found in the deposits. (3) All the terraces are inset against, and deposited upon, units $A$ through $H$ (fig. 13). 


\section{DEPOSITIONAL ENVIRONMENTS}

Even though Los Gatos Creek is basically a meandering, sand-bed, ephemeral stream in an arid environment, its depositional environments are somewhat similar to those of the classical model for a meandering stream in a nonarid environment. The model used to interpret the deposits of Los Gatos Creek, therefore, is derived from the classical meandering stream model. The depositional environments that are typical of a classical meandering stream are active channel, floodplain, and abandoned channel environments (fig. 14; Allen, 1965 and 1970; Kukal, 1971). Each of these depositional environments contains deposits of a characteristic fluvial facies. Active channel environments yield channel lag, point bar, channel bar, and bank deposits of the channel facies; floodplain environments yield floodplain, crevasse splay, and levee deposits of the overbank facies; and abandoned channel environments yield abandoned channel fill deposits of the meander cut-off facies. The major differences between the classical model for a meandering stream and the Los Gatos Creek deposits are that point bar deposits are unusually thin at Los Gatos Creek and that meander cut-offs probably do not create oxbow lakes at Los Gatos Creek but instead create dry abandoned stream channels that are later filled with abandoned channel fill deposits. The causes for these differences are described below.

The criteria used to identify the three basic facies types are grain size, primary and secondary sedimentary structures, vertical and lateral sequences, depositional rates, and position relative to other facies; these criteria are described in detail below. Also, examples of type localities along Los Gatos Creek in the preserved record for each facies are given below. For each fluvial facies deposit, the typical Los Gatos Creek deposit is described and then its applicability to the model of the ideal facies description is evaluated.

\section{Channel Facies}

Channel facies deposits can be divided into four types: channel lag, channel bar, point bar, and bank deposits. 

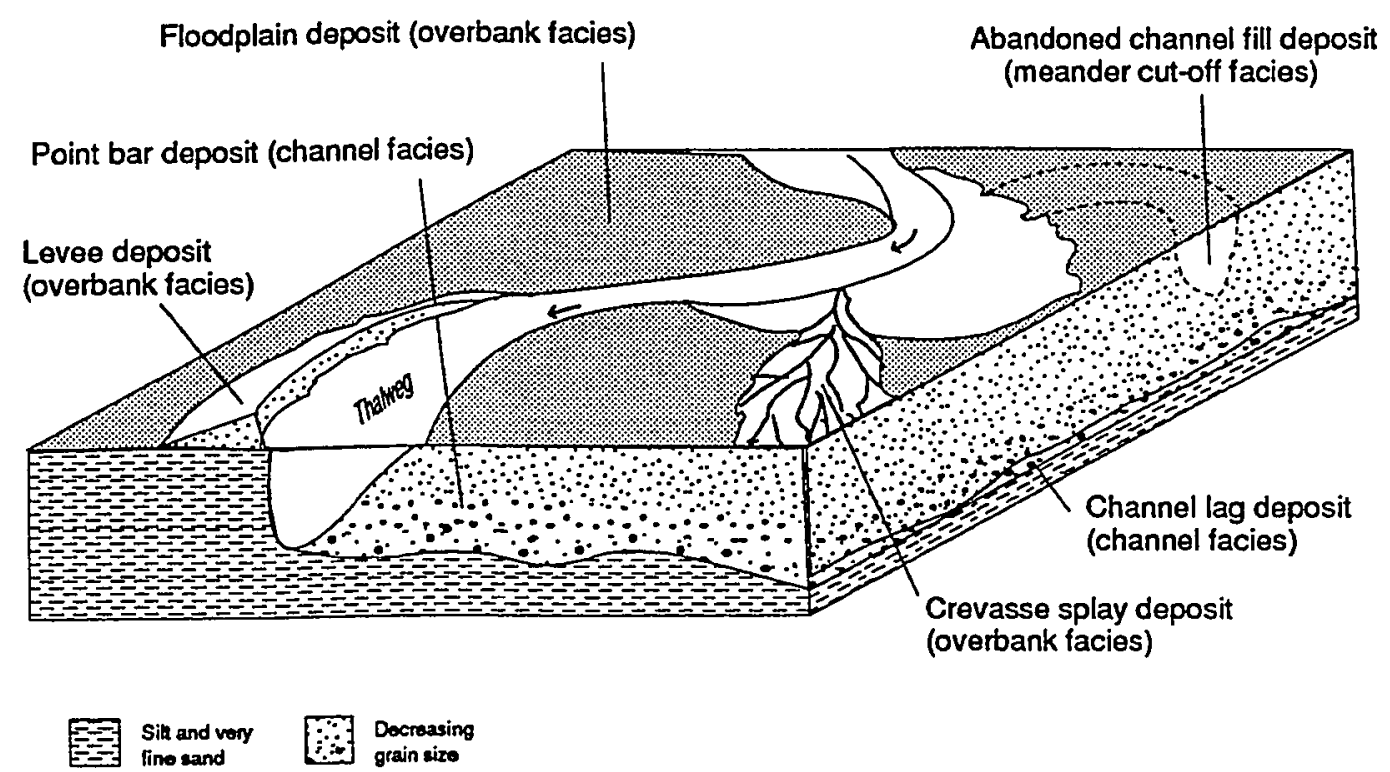

Figure 14: The classical point bar model for a meandering stream (after Collinson, 1987). The active channel environment yields channel lag, point bar, and channel bar deposits of the channel facies; the floodplain environment yields floodplain, crevasse splay, and levee deposits of the overbank facies; and the abandoned channel environment yields abandoned channel fill deposits of the meander cut-off facies. 
Channel Lag Deposits

At Los Gatos Creek these deposits are exposed as small (1.0 meter thick by 0.5 meter long) dominantly lenticular bodies of crudely stratified gravels and can be seen at localities 9 and 86-12 (see figure 2 for locations of localities, and see APPENDIX: MEASURED SECTIONS). Channel lag deposits as described by Allen (1965) generally fit this description. Two other varieties of channel lag deposits are found at Los Gatos Creek that are not described in the general model: (1) Thin (less than 1 meter thick) laterally continuous gravel layers are common. These are interpreted as having been deposited by a laterally migrating stream without a large vertical-aggradation component. These deposits can be seen at localities 86-3, 86-4 (fig. 10), 3, and 9. (2) Vertical gravel sequences no wider than present-day channel width (about 30 meters) may be present at Los Gatos Creek at locality 86-12. These are interpreted as having been deposited by an aggrading stream without any component of lateral migration.

According to Allen (1965), and as is the case at Los Gatos Creek, channel lag deposits are always overlain by other channel facies or by meander cut-off facies deposits. Examples of modern channel lag can be found nearly everywhere within the present thalweg. This lag is dominantly a pebbly very coarse sand with scattered cobbles and is found in the lowest parts of the thalweg and is also found upstream and downstream of objects that cause reduction in the flow of the stream (fig. 15A).

Channel Bar Deposits

At Los Gatos Creek, channel bar deposits range in grain size from medium sand to gravel and contain a wide range of sedimentary structures. These structures are commonly found in a sequence from bottom to top: large- and small-scale trough cross bedding, ripple-drift cross lamination, and horizontal stratification. The complete sequence, however, is rarely present. Coarser material is usually concentrated in troughs of cross beds at the base of the deposit. Channel bar deposits are usually less than 0.5 meters thick with widths of up to 10 meters and lengths of up to several 10's of meters. They are tabular in sections perpendicular to flow, and they are tabular as well as wedge shaped in sections parallel to flow. 


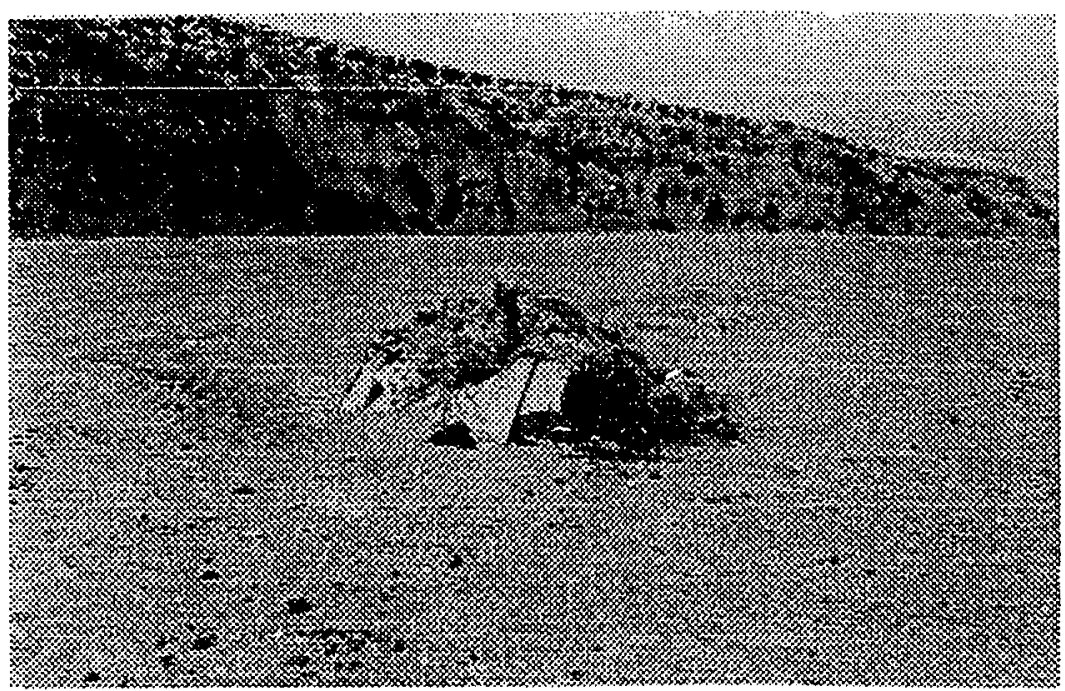

A

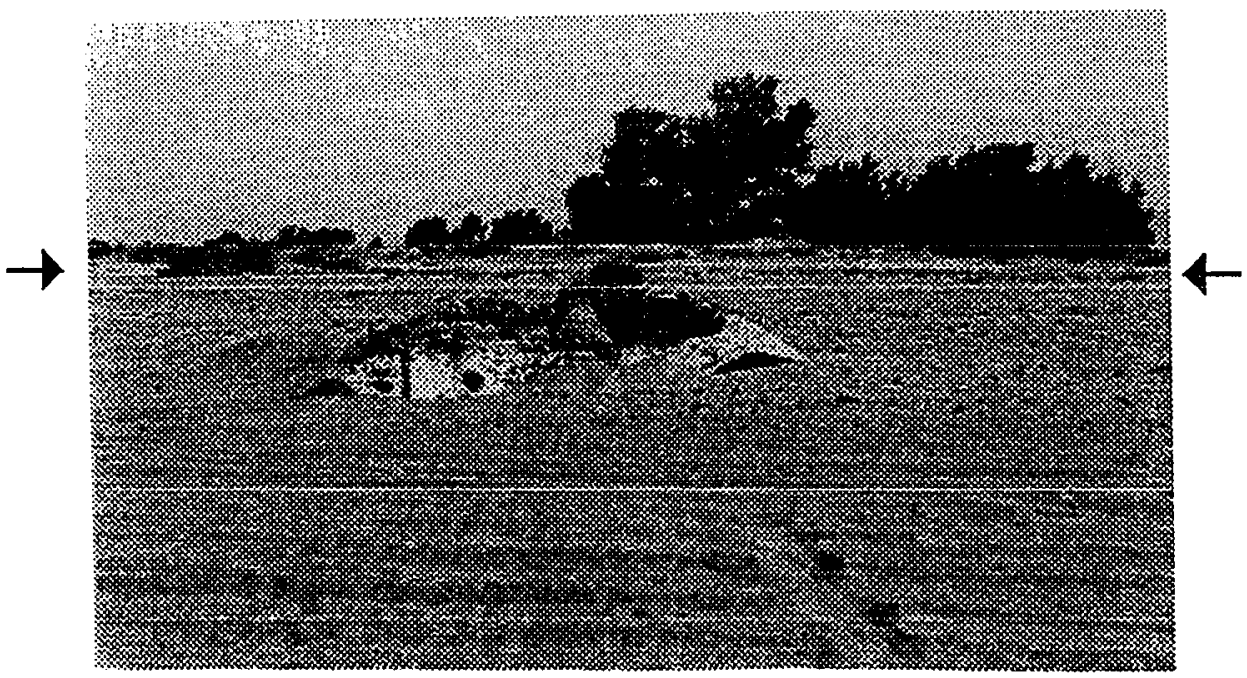

B

Figure 15: (A) Modern channel lag of pebbly very coarse sand with occasional cobble deposited around an obstacle near locality 3. View east. (B) same locality with view to south. Arrows point to edge of thalweg and beginning of point bar. Volkswagen for scale. 
In the vertical sequence, channel bars are superposed. Channel bars are always found overlying channel lag deposits and are always overlain by either point bar or bank deposits. Examples of channel bars are very common and can be seen at localities 86-3, 86-4 (fig. 10), 86-6, 86-12, and 3. Examples of modern active channel bar deposition can be found nearly everywhere within the present thalweg; an exceptionally well developed channel bar is near locality 86-12.

The model for channel bar deposits from Allen (1965) and Kukal (1971) fits the Los Gatos Creek channel bar deposit descriptions quite well. The only difference is that a complete sequence of sedimentary structures is usually present in the model.

\section{Point Bar Deposits}

The point bar deposits of Los Gatos Creek range in grain size from very coarse sand fining upward to very fine sand and silt. The sedimentary structures follow a common sequence from the bottom to the top of the deposit; large-scale trough cross bedding, planar wedge-shaped cross bedding, ripple-drift cross lamination, and horizontal lamination. The uppermost horizontal laminations may show desiccation cracks, have rain-drop imprints, or may be bioturbated. The lower part of the deposit may contain superposed channel bar deposits. Point bar deposits of Los Gatos Creek are unusually thin (often less than 2 meters thick) and the widths are probably less than or equal to the meander belt width (about 700 meters for Los Gatos Creek). Point bar deposit lengths are probably comparable to present point bar lengths (about 300 meters for Los Gatos Creek). Point bar deposits always overlie channel lag, channel bar, or bank deposits and are always overlain by deposits of the overbank facies. One edge of the deposit is usually abutted with an erosional unconformity to older deposits of any facies. See figure 14 for a sketch showing point bar deposits.

The model for the ideal point bar deposit is from Allen (1965 and 1970) and Kukal (1971). The principal difference between the Los Gatos Creek deposits and the model for the ideal point bar is that the thickness of the Los Gatos Creek point bar deposits is often much less than the total channel depth, whereas in the ideal model the thickness of the point bar deposits is equal to the channel depth. Thin point bar deposits can occur when a creek is incised and unable to overtop its banks 
(Los Gatos Creek is incised today). The point bar deposits of Los Gatos Creek may therefore indicate that the creek has been incised in the past. Another difference between the ideal point bar deposit model and the Los Gatos Creek deposits is the common presence at Los Gatos Creek of discontinuous silt stringers that disrupt the ideal sequence of sedimentary structures. These thin silt deposits may have formed during the waning stages of floods, and a series of silt stringers might represent a sequence of floods during an aggradational period.

Examples of point bars are at localities 9 and 86-6. Modern point bars can be found commonly along Los Gatos Creek on the insides of meander bends such as near localities 8 and 24. These point bars, however, are no more than 2 meters high and are often as short as 1 meter. Figure 15B is a photo of the thalweg on the outside of a meander bend showing a point bar on the inner bank of the meander. This point bar is about 1.5 meters high.

\section{Bank Deposits}

The bank deposits of Los Gatos Creek range in grain size from pebbly coarse sand at the base, fining upward to fine sand and silt. These are usually deposited atop and around slump blocks from the creeks' banks (fig. 16). The slump blocks inhibit flow within the stream and provide a locus of deposition for both the traction and suspension loads (Schumm, 1960). Sedimentary structures are not common. Ripple-drift, planar lamination, and possibly cross bedding can be present. More importantly, the general slope of the deposits is concave-upward away from the creeks' banks. Root casts are common because plants help provide a locus of deposition. Where the aggradational cycle was complete, bank deposits are as thick and as wide as the channel is deep and wide. These deposits always overlie channel lag and channel bar deposits and are always overlain by overbank facies deposits. Superb examples of bank deposits can be seen at localities 86-6 and 102. Examples of recent bank deposition in Los Gatos Creek can be found on the outsides of most meanders, while the deposits on the insides of the meanders are usually point bar deposits. Because bank deposits are only on the outsides of meanders, bank deposits can be preserved only by an aggrading stream, while all other channel facies deposits can be deposited and preserved by a migrating, nonaggrading stream. 


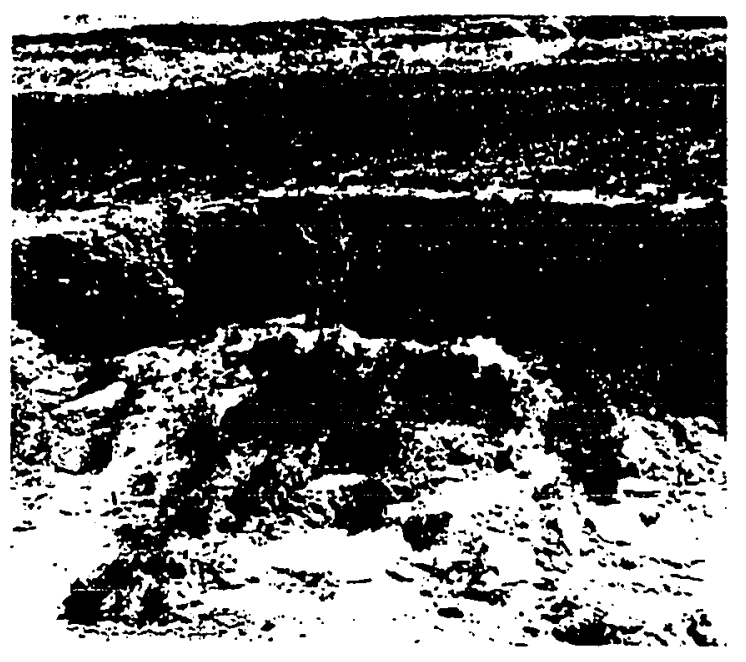

Figure 16: Modern bank deposits in Sage Creek, South Dakota around blocks of bank material which have caved into the channel. The block has not rotated, and floodplain vegetation is flourishing on the surface of the block several feet below its original position (from Schumm, 1961, Figure 20C, p. 39). 
The idealized bank deposit description for the meandering stream model from Schumm (1961) and Kukal (1971) is identical to the Los Gatos Creek bank deposit descriptions. This is not unusual because bank deposits are very common in ephemeral streams (Schumm, 1961).

\section{Qverbank Facies}

The deposits of the overbank facies are divided into 3 categories: levee, crevasse splay, and floodplain deposits.

\section{Levee Deposits}

Although levee deposits are relatively rare in the Los Gatos Creek deposits. they are very similar to the idealized levee deposit for the meandering stream model of Allen (1965 and 1970). Levee deposits in Los Gatos Creek range in grain size from fine to very fine sand to silt, and are coarsest near the channel and fine laterally away from the channel. Levees are generally composed of superposed upwardly-fining sequences of interstratified coarse and fine deposits, with each sequence representing a single overtopping of the stream's banks. The thickness of individual sequences vary from centimeters up to decimeters. Common sedimentary structures include small-scale cross bedding (amplitude less than a few centimeters), horizontal lamination, and desiccation cracks. Because levees exist in well oxidized environments, the deposits are usually well oxidized and oxidation halos surrounding root marks are common. Levee deposits at Coalinga are about 1.5 to 2.0 meters thick and overlie point bar, floodplain, or bank deposits.

Examples are found at localities 86-6 and 27. At locality 86-6 the deposits consist of interbedded 20- to 60-centimeter-thick beds of small-scale, cross-bedded, oxidized, medium sand and silt. Modern levees are present nearly everywhere along the modern creek banks. Most of these are rather small and can be detected only by the slight rise in elevation of the floodplain as one approaches the creek perpendicularly. In some cases they are high enough to be measured from the topographic map. One such case is a levee about 1.5 meters high on the north and south banks of Los Gatos Creek 0.5 miles west of the confluence with Zapato Chino Creek (fig. 2). Another about 1 meter high is on the south bank near Turk Narrows. 


\section{Crevasse Splay Deposits}

The Los Gatos Creek crevasse splay deposits fit the model from Allen (1965 and 1970) for the crevasse splay deposits of a meandering stream. Crevasse splay deposits in Los Gatos Creek range in grain size from pebbly to coarse to fine sand and sometimes contain slump blocks from the levee if the deposit is near the levee. They are usually deposited as upward fining sequences with erosional channeled bases, often in a braided pattern, into underlying deposits. The closer to the levee, the more pronounced the channeled base. Common sedimentary structures include trough cross bedding, planar cross bedding, ripple-drift cross lamination, and horizontal lamination (fig. 17). The deposits usually range from about 10 centimeters to about 100 centimeters thick and become thin away from the channel. In plan view, the deposits close to the channel are narrow and sinuous and become broad and lobate away from the channel. Crevasse splay deposits always overlie floodplain or levee deposits and can be overlain by deposits of any depositional facies, but most commonly interfinger with and are overlain by floodplain deposits. Crevasse splay deposits are present in most exposures of overbank facies deposits at Los Gatos Creek.

Examples of crevasse splay deposits are at localities 21 and 101 (fig. 8). However, due to extensive farming on the banks of Los Gatos Creek, recent crevasse splay deposits have not been recognized. The expected location for these deposits would be atop the present alluvial plain alongside the channel.

\section{Floodplain Deposits}

The Los Gatos Creek floodplain deposits fit the models from Allen (1965 and 1970) and Kukal (1971) for the idealized floodplain deposit of a meandering stream perfectly. The floodplain deposits of Los Gatos Creek are usually composed of fine to very fine sand and silt and local medium to coarse sand. Common sedimentary structures are parallel laminations and cross laminations, but these are often disrupted by bioturbation and soil development. Mudcracks, raindrop imprints, root fillings (often with oxidation halos), and animal burrows are common. Thickness of floodplain deposits is limited only by basin depth; the areal extent is limited only by valley size. The deposits, however, are more common 


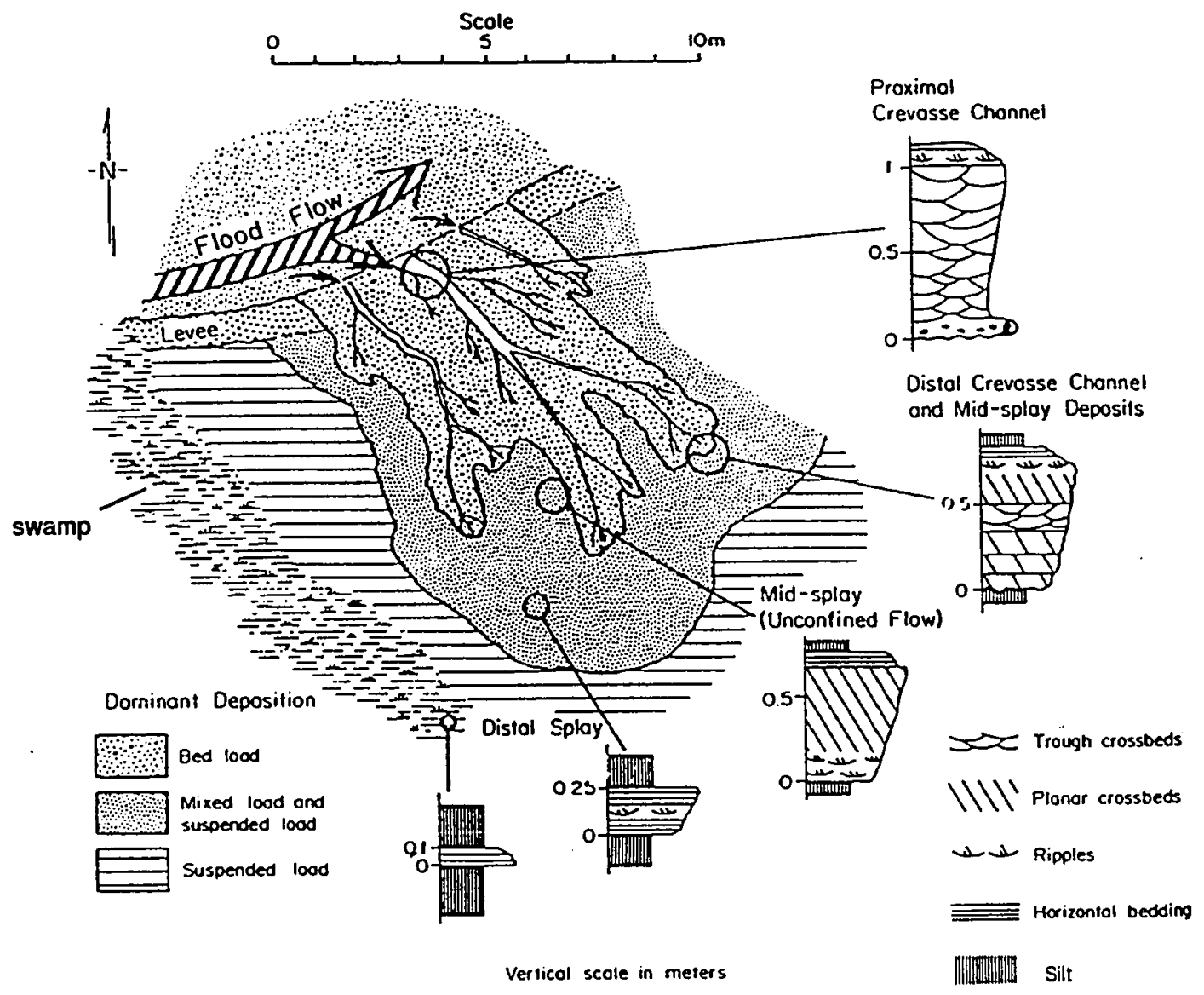

Figure 17: Schematic representation of the lateral variation in primary sedimentary structures of a crevasse splay deposit. Diameters of circles represent relative grain sizes. After Tyler and Ethridge (1983). 
outside of the meander belt because channel facies deposits are usually dominant within the meander belt. Floodplain deposits usually overlie point bar, levee, or crevasse splay deposits but can be overlain by deposits of any facies. Dispersed throughout most floodplain deposits there are thin (about 2 centimeter thick) layers of charcoal atop thin (about 2 centimeter thick) reddened layers of silt. The reddened layers are interpreted as silts that have been thermally oxidized by the fires that produced the charcoal deposits.

Examples of floodplain deposits are found at localities 101 and 1 (figures 8 and 9). Deposition of floodplain deposits on the present alluvial plain is not occurring today because the present channel size is too large to be overtopped by even a 50 year flood. However, if the creek were able to overtop its banks, floodplain deposition would occur on the alluvial plain adjacent to the channel.

\section{Meander Cut-off Facies}

The deposits of the meander cut-off facies are of only one type, abandoned channel deposits.

\section{Abandoned Channel Deposits}

These deposits range in grain size from coarse to fine sand, silt, clay, and sometimes gravel. Two end member types of channel cut-offs are possible, each resulting in different deposits: chute cut-off and neck cut-off. In chute cut-off environments gravel lag is concentrated at the base of the channel, trough cross bedded and ripple-drift cross laminated sand is deposited along the walls and floor of the channel, and silt and clay deposits are nestled within the sands. In neck cutoff environments sand plugs are deposited at each end of the meander loop, and finely laminated silt and clay are deposited throughout the length of the meander loop.

Mudcracks and raindrop imprints are common in the silt and clay deposits of both chute cut-off and neck cut-off deposits. The height and width dimensions of these deposits are those of the channel they fill. The length is that of one meander loop. In plan, the deposits are curved. In neck cut-off deposits the two ends of the abandoned meander loop nearly meet, while in chute cut-off they do not (fig. 18). In cross section one side of the channel is usually transitional to point bar 

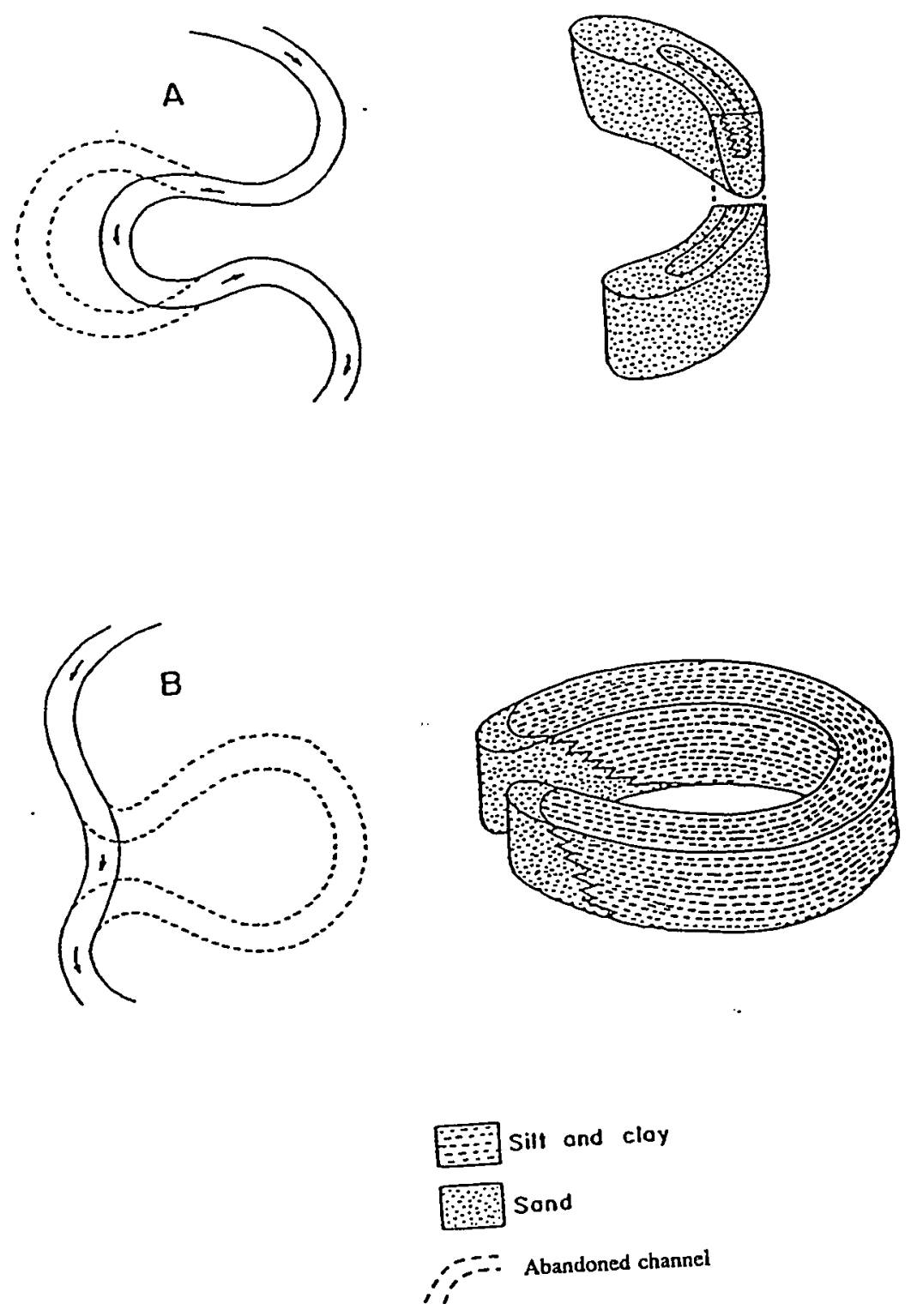

Figure 18: Abandoned channel mechanisms and resulting deposits. A. Chute cut-off. B. Neck cut-off. After Allen (1965). 
or bank deposits and the other side is in erosional unconformity with older deposits of any facies. Abandoned channel deposits can overlie and be overlain by deposits of any facies. The neck cut-off member is the most common end member at Los Gatos Creek.

Superb examples of abandoned channel deposits are present at locality 86-6. An example of a recently abandoned channel can be seen on the north bank of the creek near locality 103 in section 36 of township 20 south and range 15 east (fig. 2). On the 195615 minute Coalinga Quadrangle the channel is drawn with a large meander loop bending to the north, but on the 19567.5 minute Coalinga Quadrangle with 1979 photorevisions the channel is drawn without this loop (fig. 19).

The Los Gatos Creek abandoned channel deposits fit the model from Allen (1965 and 1970) for the ideal abandoned channel deposit quite well. 


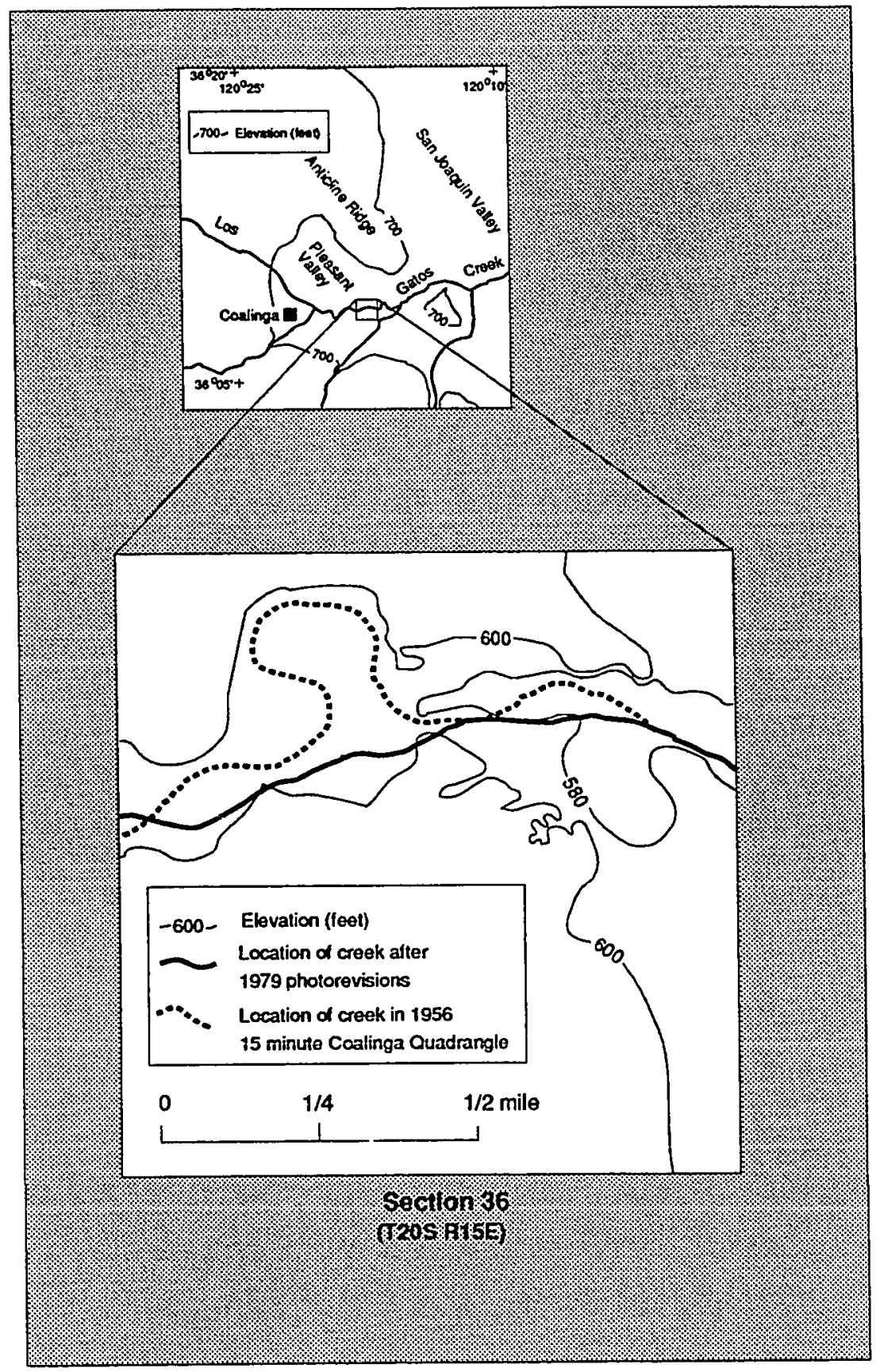

Figure 19: Location of channel in Los Gatos Creek that was abandoned sometime between 1956 and 1979. 


\section{DEGRADATIONAL AND AGGRADATIONAL HISTORY}

Interpretations of the degradational and aggradational history of Los Gatos Creek is difficult because of the large number of channel fills of various ages, but the actual history is relatively well explained by a model involving three episodes of aggradation and three episodes of degradation. The first of these episodes began sometime before 7000 years ago and the last few of these episodes possibly continue along some reaches of Los Gatos Creek today. During each episode, the locus of incision and the locus of deposition appears to have progressed upstream.

Figure 20 is a geographic and chronologic representation showing units $A$ through I grouped into Fills 1 through 3, and the intervening Degradational episodes 1 through 3. These fills resulted from Aggradational episodes 1 through 3. Radiocarbon dates are plotted along the horizontal axis according to their distance in miles downstream of the town of Coalinga and are plotted along the vertical axis according to their age in calibrated ${ }^{14} \mathrm{C}$ years before present (age increases downward along the axis). By maintaining the horizontal axis constant at a particular locality along the creek and allowing the vertical axis to vary, one can examine the aggradational and degradational history through time at that locality. For example, at locality 86-12 Aggradation 1 occurred about 6500 calibrated ${ }^{14} \mathrm{C}$ years ago (resulting in the deposits of Fill 1), Degradation 1 occurred about 3500 years ago, a long Period of aggradation (Aggradation 2) occurred again about 3000 years ago (resulting in the deposits of Fill 2), Degradation 2 occurred again about 50 calibrated ${ }^{14} \mathrm{C}$ years ago (calendar year 1900), Aggradation 3 then occurred about 10 years ago (calendar year 1940) resulting in the deposits of Fill 3, and finally Degradation 3 began about the calendar year 1960. By holding the vertical axis constant at a particular calibrated ${ }^{14} \mathrm{C}$ years before present, one can read off the diagram where along the creek aggradation and degradation was occurring. For example, 2000 years ago Aggradation 2 was occurring 3.2 miles east of Coalinga at locality 86-4 (resulting in the basal deposits of Fill 2) while Degradation 1 was occurring 2.8 miles east of Coalinga at locality 103. With this figure the upstream migration of degradations and aggradations can clearly be seen. 


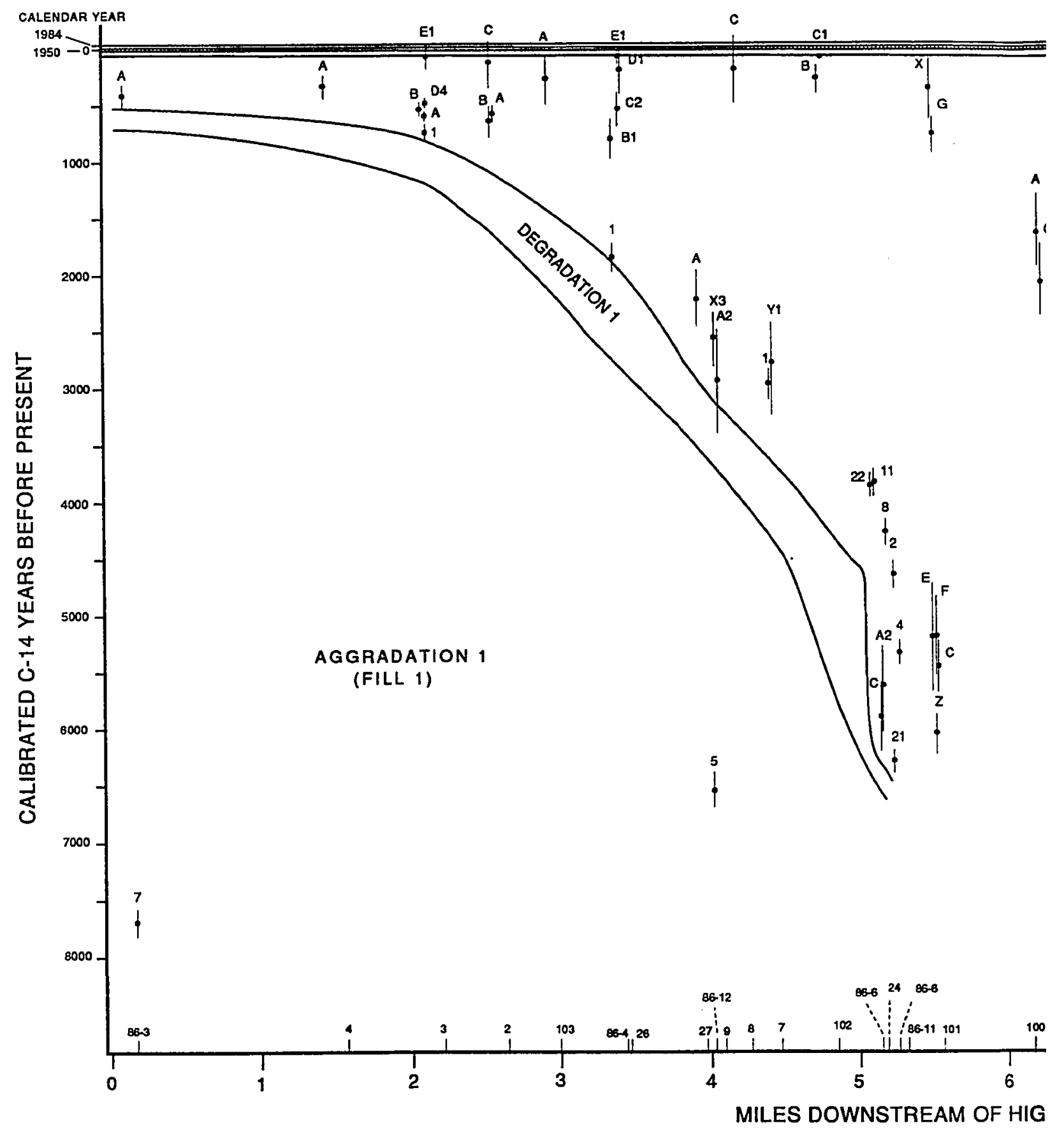

Figure 20: Radiocarbon dates arranged along the horizontal axis according to their geographic : This figure shows the timing and locations of Aggradations 1 through 3 and Degradations 1 throu! younger in sections upstream, it appears that the locus of deposition of this fill migrated upstream. 
$\mid$ 


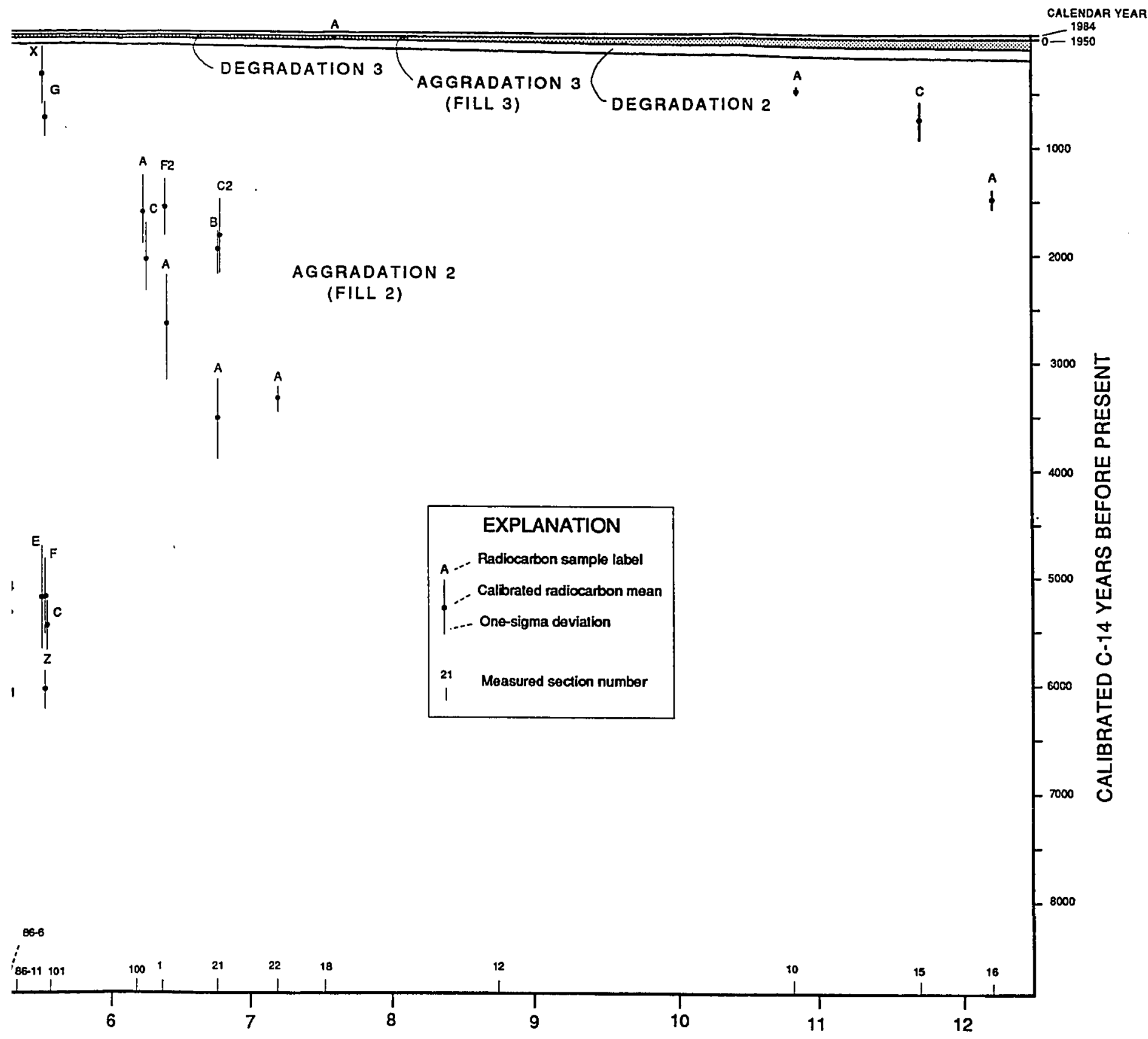

REAM OF HIGHWAY 198 BRIDGE AT CREEK

heir geographic position along the cross section in Figure 2. dations 1 through 3 . Because the base of Fill 2 becomes progressively rated upstream. 
The following is a detailed description of the localities and ages of aggradation and degradation along the creek.

\section{Aggradation 1}

Aggradation 1 resulted in the deposits of Fill 1 (units A and B), began before 7735 years ago and ended after 6615 years ago. Unit $A$ is a 3-meter-thick silty floodplain deposit 7735 years old (fig. 7) and is found at locality 86-3, at the western edge of Pleasant Valley near Coalinga. Because this is a floodplain deposit, the location of the thalweg during deposition of unit A must have been below the top of unit $\mathrm{A}$ which is 50 centimeters below the present thalweg.

Unit B is located at locality $86-12$ at the eastern edge of Pleasant Valley, about 1.5 miles west of the western flank of the Coalinga Anticline. It was deposited 6615 years ago. The deposits are 3.7 meters thick and are interpreted as gravel lags and bars from a paleo-channel course.

Unit $B$ is at a higher elevation above the present thalweg than unit $A$, and since there is no evidence to presume otherwise, continued aggradation is assumed between the deposition of these two units. The top of unit B is 3.7 meters above the present thalweg; assuming continued aggradation between units $A$ and $B$, the stream aggraded at least 4.2 meters during deposition of this fill.

\section{Degradation 1}

The major degradational episode, Degradation 1, began sometime before the deposition of the earliest deposits of Fill 2, about 6400 years ago, and possibly continues today. This degradation occurred near the western flank of the anticline at localities 86-11 and 86-6 about 6000 years ago and then migrated upstream through Pleasant Valley toward Coalinga (fig. 20). This degradation ranged from about 8.2 meters deep (localities 86-11 and 86-6) to about 3.3 meters deep (locality 9). These incision depths can be seen in the channel cuts that are filled with Fill 2. The degradation was 8.2 meters deep at localities 86-11 and 86-6 about 6000 years ago (base of unit C), 3.3 meters deep at locality 9 about 3900 years ago (base of unit E), at least 2 meters deep at locality 86-4 about 3000 years ago (base of unit $F$ ), at least 4.8 meters deep at locality 3 about 1200 years ago (base of unit $G$ ), and at 
least 3.5 meters deep at locality $86-3$ about 600 years ago (base of unit $\mathrm{H}$ ). Today, Degradation 1 might still be active somewhere upstream of locality 86-3.

\section{Aggradation 2}

Aggradation 2, resulting in the deposits of Fill 2, began sometime before 6400 years ago as evidenced by the gully fill deposits at localities 86-11 and 86-6 near the western flank of the anticline. Aggradation in the channel did not begin until about 4500 years ago, after which the locus of deposition is interpreted to have migrated upstream, from locality 86-6 to Coalinga, closely following the upstream migration of the locus of Degradation 1. Aggradation 2 possibly still continues somewhere upstream of locality 86-3. The interpretation of upstream migration is based on the fact that the 5 channel facies deposits at the base of Fill 2 become younger upstream, and that only three possible degradational and aggradational scenarios exist for the formation of these deposits: (1) The 5 channel facies deposits were deposited during 5 individual aggradational episodes, each of which was separated by a degradational episode; (2) All of the 5 channel facies deposits were deposited during 1 aggradational episode with no intervening degradational episodes; and (3) Any combination of the above two scenarios where 2 to 4 aggradational episodes and 1 to 3 degradational episodes were involved. Because it seems best to choose the least complicated model, scenario 2 is chosen as the model for the formation of these deposits. Examples in the literature of streams in the western United States where an upstream migration of the locus of aggradation and of the locus of degradation has been documented are plentiful (for example: Thornthwaite, Sharpe, and Dosch (1942); Schumm and Hadley (1957); Schumm (1961); Weldon, in preparation).

Fill 2 is comprised of units C, D, E, F, G, and $\mathrm{H}$ and has a total thickness ranging from 8.8 meters at locality 103 near Coalinga to 13.0 meters at locality $86-$ 11 on the western flank of the anticline.

\section{Fill 2 - Lower Part}

Before 6370 years ago Los Gatos creek abandoned a segment of its channel near localities $86-11$ and $86-6$, probably by a meander cut-off. This abandoned 
channel was filled from about 6370 to about 3500 years ago with an 8.2 meter-thick sequence of unit $\mathrm{C}$ deposits. During this time, levee deposits at locality 24 and floodplain deposits at locality 101 were formed.

About 4500 years ago the Aggradation 2 cycle began in the channel at locality 86-6 and continued until about 4000 years ago, when the locus of aggradation moved upstream. This pulse of aggradation is represented by the 3.0 meter-thick channel facies deposits of unit $D$.

From about 3000 to about 2700 years ago, channel facies deposits 1.0 meter thick were deposited in the thalweg at locality 9. During this time bank deposits at locality 7, abandoned channel deposits at locality 86-6, and overbank facies deposits at localities 1, 86-12 and 27 were formed. These deposits comprise unit $E$. At the end of deposition of the gravel lag of unit $D$ and the beginning of deposition of the gravel lag of unit $\mathrm{E}$, the maximum thalweg gradient between localities $86-6$ and 7 was $0.13 \%$ measured linearly on the topographical map between the localities. This is $67 \%$ less than the present thalweg gradient of $0.40 \%$ derived by a linear measurement downvalley on the topographical map from locality 86-6 to locality 16 and from locality 3 to locality 86-4. This dramatic decrease in stream gradient causes sediment to be deposited within the reach of low gradient. As localized deposition continues within this reach, the stream gradient immediately upstream of the reach decreases. This decrease in gradient upstream of the original low-gradient reach will in turn initiate deposition. Therefore, localized deposition in a low-gradient reach can cause an upstream migration of lessening stream gradients and therefore an upstream migration in the locus of deposition.

By 2000 years ago, deposition in the thalweg had moved upstream to locality 86-4. Deposition at this locality continued until about 1700 years ago and resulted in the 3.3 meter thick channel facies deposits of unit F. During this shift in the locus of deposition in the thalweg (the oldest gravel lag deposits of unit $E$ and the youngest gravel lag deposits of unit $F$ ) the thalweg gradient was $0.11 \%$, which is $72 \%$ less than the general modern stream gradient of $0.40 \%$. During and following this change in the locus of thalweg deposition, the overbank facies deposits of unit $\mathrm{F}$ were deposited at localities 16, 22, 21, 100, and 101.

By about 1000 years ago channel facies deposition had moved upstream to locality 3 and continued until about 800 years ago. This resulted in the $3+$ meter 
thick channel facies deposits of unit G. During this shift of the locus of deposition, the thalweg gradient was $0.24 \%$, which is $40 \%$ less than the current stream gradient. During and following this deposition, the overbank facies deposits of unit $\mathrm{G}$ were deposited at localities $15,101,26,86-4,103$, and 3 .

\section{Fill 2 - Upper Part}

The latter part of Aggradation 2 resulted in the deposits of the upper part of Fill 2 (unit $\mathrm{H}$ ). About 500 years ago channel facies deposition had migrated upstream to locality 86-3. During this migration the thalweg gradient was $0.34 \%$, which is $15 \%$ less than the modern stream gradient of $0.40 \%$. Deposition in the thalweg continued at locality 86-3 until about 400 years ago, when the locus of deposition in the channel had migrated upstream. From about 500 to about 40 years ago deposition of the overbank facies of unit $\mathrm{H}$ occurred along Los Gatos Creek at every locality except at locality 8 , where gully fill deposits filled a channel 3.4 meters deep and 4.0 meters wide about 300 years ago. This channel is interpreted as a small tributary gully above the active channel much like those present near locality 3.

At localities 15, 22, 21, 102, and 3, coarser material, much like channel deposits, was deposited. These, also, are interpreted as filling small gullies tributary to the main stream. Three of these localities $(22,21,102)$ are near major drainages that spill into Los Gatos Creek; during flood, the combined drainages of Los Gatos Creek and the major tributary drainages might cause overtopping of the creek's banks and deposition of coarser sediment in the small gullies.

The deposition of unit $\mathrm{H}$ marks a major change in the vigor of Aggradation 2. This is reflected in much coarser deposits, more rapid deposition rates, and much greater geographic distribution.

\section{Degradation 2}

Degradation 2 began about 190 years ago at locality 16 where Los Gatos Creek spills into the San Joaquin Valley, and migrated upstream to where it might still be active upstream of Coalinga. This degradation occurred at each locality after the end of the deposition of unit $\mathrm{H}$ (top of the present creek banks). The age of this 
episode is obtained at each locality using the youngest available date and extrapolating to the age of the bank top using the mean vertical accretion rate. Incision depths range from a minimum of 0 to 3.0 meters. The minimum depth of incision for any locality is the same as the depth of the present thalweg below the top of the channel facies deposits of Fill 2.

\section{Aggradation 3}

Aggradation 3 began at locality 16 shortly before calendar years 1853-54 and resulted in the deposits of Fill 3 (unit 1 ). This aggradation possibly migrated upstream toward Coalinga, to where it ceased shortly after 1955 (fig. 21). Deposits reach a maximum thickness of between 4.9 and 6.4 meters. The age and thickness are determined from the change in the distance from creek bed to creek bank top from a 1853-54 survey to the 19567.5 minute Guijarral Hills Quadrangle near locality 12.

Fill 3 (unit I) can be found nearly everywhere along the present thalweg as cut terraces (figures 12 and 13). The terraces assigned to Fill 3 are immediately adjacent to the thalweg and are treated differently than the terraces that are present at various elevations above the thalweg and are farther from the creek. The Fill 3 terraces have a maximum height of about 1.5 to 2.0 meters, but, because the base of Fill 3 may be concealed by deposits within the present thalweg (for example thalweg elevation of today is 3 meters above the base of Fill 3 deposits near locality 12), the total thickness of the fill is unknown. Data are insufficient to determine with certainty that this fill was formed by backfilling; the mechanism of upstream migration for the deposition of Fill 3 is only speculative.

Numerous cut terraces inset against and atop Fill 1 and 2 deposits throughout the channel are higher in elevation above the thalweg than the Fill 3 terraces and are of unknown age and origin. Because this thesis is an outgrowth of a study on the deformation rates of the Coalinga Anticline and, as such, sought after the oldest Holocene deposits along Los Gatos Creek, these youngest terraces were not studied in detail for this thesis. However, if a detailed study were done, it might help elucidate the causes of Aggradations 1 and 2. 


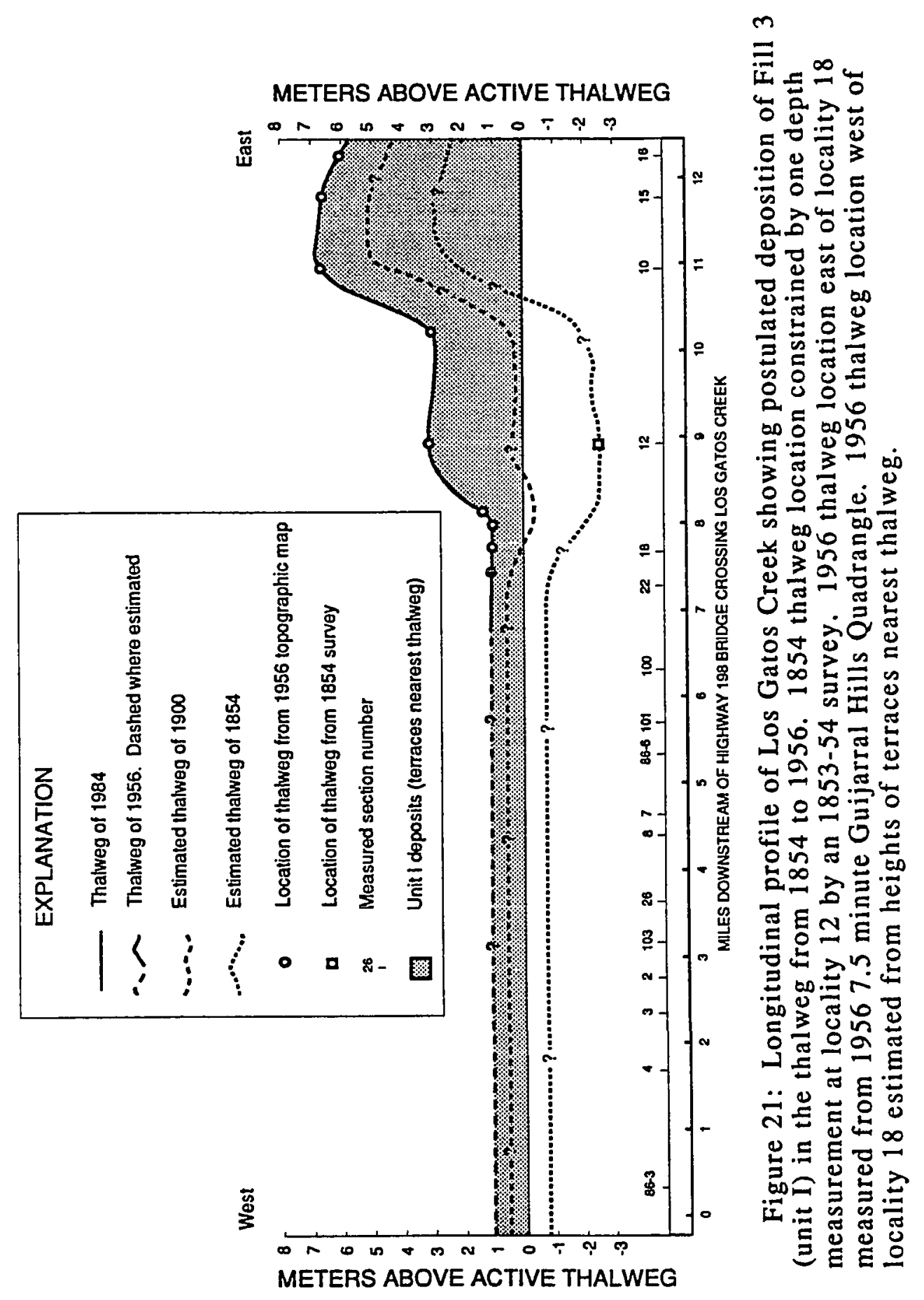




\section{Degradation 3}

Degradation 3 began shortly after the year 1955 and possibly continues even today. The maximum incision depth is about 6.5 meters. This depth and age are determined from the change in the distance of creek bed to creek bank top from the 1956 7.5 minute Guijarral Hills Quadrangle to a 1984 vertical-angle leveling survey conducted by Atwater and others (1989). These data yield a degradation rate of 224 to $232 \mathrm{~mm} / \mathrm{yr}$. 


\section{CAUSES OF DEGRADATIONAL AND AGGRADATIONAL EPISODES}

The possible causes of aggradation and degradation in a fluvial system can be categorized as changes of variables that are either external or internal to the fluvial system (Schumm, 1977). The external variables are base level and climate. The internal variables, or intrinsic geomorphic thresholds, are stream gradient, sediment yield, and stream discharge. Internal variables can change independently of external variables; for example, a meander cut off by a stream during high flow will steepen the stream gradient (internal variable). Internal variables can also change as a result of a change in an external variable; for example, a drop in base level (external) will steepen the stream gradient (internal).

The three aggradational and three degradational episodes of Los Gatos Creek can be correlated to changes in both the external and internal variables of the system. In each of the following descriptions of the external and internal variables of the system, an explanation of how the variable can cause either aggradation or degradation is given and the possible role of the variable to either the aggradational or degradational episodes of Los Gatos Creek is given.

\section{External Variables}

Base Level

If the base level of a graded stream is changed (a graded stream is one which is in equilibrium among slope, load, volume, and velocity as described by Schumm, 1977, and as defined by Mackin, 1948), the stream will either incise or aggrade accordingly until it reaches grade with its new base level (Schumm, 1977). A rise in base level will cause the stream to aggrade; a drop in base level will cause the stream to incise. Possible causes for base level change are tectonic uplift or subsidence, subsidence by means other than tectonics (such as extensive groundwater-overdraft), and eustatic sea level changes. Because eustatic sea level changes often coincide with changes in the global climate, the effect of changes in the sea level are not considered here. 
Rising of Base Level. The maximum uplift rate for the Coalinga Anticline is shown to average less than 0.21 meters per 1000 years during Pliocene to Holocene time (see section titled DEFORMATION RATE ESTIMATE FOR THE COALINGA ANTICLINE) and average less than 0.11 meters per 1000 years during the Holocene (Atwater and others, in press). The time span of interest in this study is about 7000 years because the oldest Holocene deposits dated in Los Gatos Creek are about 7000 years old. Using the maximum Holocene uplift rate, the Coalinga Anticline has been uplifted no more than 0.77 meter during these last 7000 years. An uplift of 0.77 meter at the anticline with respect to the syncline would change the creek's gradient by only $3.2 \%$ over a distance of 6 kilometers. Compared to gradient changes of 38 to $92 \%$ (Schumm, 1961) and 25 to $35 \%$ (Weldon, in press) that have been responsible for aggradation and degradation in other basins, $3.2 \%$ seems insufficient to be the sole or primary cause of the degradational and aggradational episodes that are documented for Los Gatos Creek. Therefore, tectonic uplift of the Coalinga Anticline appears to have had negligible effect on the aggradational and degradational episodes of Los Gatos Creek.

The change in sinuosity of Los Gatos Creek as it crosses the Coalinga Anticline also argues in favor of a negligible effect from the uplift rate for the Coalinga Anticline. Flume experiments by Ouchi (1985) suggest that a stream meandering across actively uplifting alluvium should straighten upstream of the uplift and become more sinuous downstream, so as to maintain a constant channel gradient across the bulge. At the Coalinga Anticline, however, Los Gatos Creek straightens downstream of the anticline and becomes more sinuous upstream of the anticline which is opposite to what would be expected from uplift at the anticline.

Lowering of Base Level. Between 1949 and 1969 groundwater-overdraft near Coalinga caused ground subsidence of up to 6 meters near Huron (Munn and others, 1981; see figure 2 for location). Subsidence ranged from about 0 meters at the anticline to about 2 meters near locality 16 at the eastern end of the cross section shown in figure 2 (Ireland and others, 1984). This subsidence caused a lowering in base level for Los Gatos Creek and was probably a contributing factor for Degradation 3 which occurred after 1955 and had a maximum incision depth of about 6.5 meters. 
Climate

The timing of three of the major aggradational and degradational episodes of Los Gatos Creek appears to coincide with changes in the climate that have been documented elsewhere in Califomia for the Holocene epoch. The following is a summary of the major Holocene climatic changes that have been documented in California. See table 5 for a tabulation of these changes and correlations with the aggradational and degradational episodes of Los Gatos Creek.

California Climatic Changes. At the beginning of Holocene time, about 11000 to 13000 years ago, the climate in north-central, central, and central-eastern California experienced a sudden increase in temperature and decrease in precipitation (Davis and others, 1985). In the north-central Coast Ranges of California the resultant climate was very similar to today's climate, but in central and central-eastern California, closer to Los Gatos Creek, the resultant climate was similar in temperature but much drier than today's climate (Davis and others, 1985). Pollen studies at Clear Lake (Adam and others, 1981; Adam and West, 1983; and Sims and others, in press), and at Barley and Tule Lakes (West, unpublished reports), all in the north-central Coast Ranges, indicate that at the end of the last glacial period about 13000 years ago the climatic shift toward warm conditions was accompanied by a mean annual temperature increase of $7^{\circ}$ to $8^{\circ} \mathrm{C}$ and a precipitation decrease of about 200 centimeters to a climate closely approximating today's climate (Adam and West, 1983). However, in central and central-eastern California, pollen studies at Balsam Meadow (Davis and others, 1985), Osgood Swamp (Adam, 1967), Swamp Lake (Batchelder, 1980), lower Kings Canyon (Cole, 1983), Gabbott Lake (Sullivan, 1985; Mackey and Sullivan, 1986) and Exchequer Meadow (Davis, 1986; Wood, 1975) indicate that the climatic change at the end of the last glacial period occurred about 11000 years ago and that the resulting climate was much drier than that of today's (Moratto and others, 1988).

The pollen records from Barley, Tule, and Clear Lakes indicate that at about 7000 years ago the climate again shifted toward warmer and possibly drier conditions in north-central California with an estimated mean annual temperature rise of about $1.2^{\circ}$ to $2.1^{\circ} \mathrm{C}$ (Adam and West, 1983). However, in central and 
Table 5: Callfornia cllmatic changes and corralatione to

Los Gatos Crook aggradationat and degradational history.

\begin{tabular}{|c|c|c|c|c|c|}
\hline $\begin{array}{c}\text { Yoars Bofore } \\
\text { Prosent }\end{array}$ & $\begin{array}{l}\text { Type of } \\
\text { study }\end{array}$ & Location & $\begin{array}{c}\text { Climatle } \\
\text { Change }\end{array}$ & Author & $\begin{array}{l}\text { Siream } \\
\text { Reaponse }\end{array}$ \\
\hline 13000 & Pollen & $\begin{array}{l}\text { Clear Lake } \\
\text { Bantey Lake } \\
\text { Tule Lake }\end{array}$ & \begin{tabular}{c|} 
Increase in \\
Temperature \\
Decroase In \\
Precipitatlon
\end{tabular} & $\begin{array}{c}\text { Adam and Wost } \\
1983\end{array}$ & \\
\hline 11000 & Pollen & \begin{tabular}{|c|} 
Balsam Meadow \\
Osgood Swamp \\
Swamp Lake \\
lower KIngs Canyon \\
Gabbott Lake \\
Exchequer Meadow
\end{tabular} & $\begin{array}{l}\text { Increase in } \\
\text { Temperature } \\
\text { Decrease in } \\
\text { Precipliation }\end{array}$ & $\begin{array}{l}\text { Moratto and } \\
\text { others, } 1988\end{array}$ & $\begin{array}{l}\text { No record } \\
\text { of Impact }\end{array}$ \\
\hline 7000 & Pollen & $\begin{array}{l}\text { Clear Lake } \\
\text { Barley Lake } \\
\text { Tule Lake }\end{array}$ & $\begin{array}{l}\text { Increase in } \\
\text { Temperature } \\
\text { Decrease in } \\
\text { Precipitatlon? }\end{array}$ & $\begin{array}{c}\text { Adam and West } \\
1983\end{array}$ & \\
\hline 7000 & & \begin{tabular}{|} 
Balsam Meadow \\
Osgood Swamp \\
Swamp Lake \\
lower KIngs Canyon \\
Gabbott Lake \\
Exchequer Meadow
\end{tabular} & $\begin{array}{l}\text { Increase in } \\
\text { Temporature? } \\
\text { Increase in } \\
\text { Preclpitation }\end{array}$ & $\begin{array}{l}\text { Moratto and } \\
\text { others. } 1988\end{array}$ & $\begin{array}{l}\text { Aggradation } 1 \\
\text { began abour } \\
7735 \text { years ago }\end{array}$ \\
\hline $8200-7600$ & Hlgh lake stand & Tulare Lake & & Marchand, 1977 & \\
\hline 3000 & Pollen & $\begin{array}{l}\text { Balsam Meadow } \\
\text { Osgood Swamp } \\
\text { Exchaquar Meadow } \\
\text { Dinky Meadow } \\
\end{array}$ & \begin{tabular}{|c|} 
Decrease in \\
Temperature \\
Increase in \\
Precipitation \\
\end{tabular} & \multirow{5}{*}{$\begin{array}{l}\text { Moratto and } \\
\text { others, } 1988\end{array}$} & \multirow{5}{*}{$\begin{array}{l}\text { No record } \\
\text { of impact }\end{array}$} \\
\hline 3000 & Treo-Aing & Foxtall Pine & $\begin{array}{l}\text { Decrease in } \\
\text { Temperature } \\
\text { increase in } \\
\text { Precipltation } \\
\end{array}$ & & \\
\hline 3300 & Treo-Pling & Bristlecone Pine & $\begin{array}{l}\text { Decrease in } \\
\text { Temperature } \\
\text { Increase in } \\
\text { Precipitation }\end{array}$ & & \\
\hline 3000 & Stratlgraphy & \begin{tabular}{|c|} 
Osgood Swamp \\
Gabbott Lake \\
Tule Lake \\
Balsam Meadow \\
Exchequer Meadow \\
Dinky Meadow \\
Harden Pond \\
Upper Cabin Meadow
\end{tabular} & $\begin{array}{l}\text { Increase in } \\
\text { Proclpitation }\end{array}$ & & \\
\hline 1500 & $\begin{array}{c}\text { Treo-Ring } \\
\text { Pollen }\end{array}$ & $\begin{array}{l}\text { Bristlecone Pine } \\
\text { Foxtall Pine } \\
\text { Tule Lake }\end{array}$ & $\begin{array}{l}\text { Increase in } \\
\text { Temperature } \\
\text { Decrease in } \\
\text { Precipitation }\end{array}$ & & \\
\hline 700 & Tree-fing & $\begin{array}{c}\text { Bristlecone Pine } \\
\text { Foxtall PIne }\end{array}$ & \multirow[b]{2}{*}{$\begin{array}{c}\text { Decrease in } \\
\text { Temperature } \\
\text { Increase in } \\
\text { Preclpitatlon }\end{array}$} & \multirow[b]{2}{*}{$\begin{array}{l}\text { Moratto and } \\
\text { others, } 1988\end{array}$} & \multirow[b]{2}{*}{$\begin{array}{l}\text { Upper part of } \\
\text { Aggradation } 2 \\
\text { began about } \\
500 \text { years ago }\end{array}$} \\
\hline 700 & Stratlgraphy & \begin{tabular}{|c|} 
Tule Lake \\
Balsam Meadow \\
Exchequer Meadow \\
Dinky Meadow \\
Harden Pond \\
Upper Cabln Meadow
\end{tabular} & & & \\
\hline \multirow[t]{2}{*}{200} & \multirow[b]{2}{*}{ Low lake stand } & $\begin{array}{l}\text { Bristlecone PIne } \\
\text { Foxtall Pine }\end{array}$ & $\begin{array}{c}\text { Increase in } \\
\text { Temperature } \\
\text { Decrease in }\end{array}$ & \multirow[t]{2}{*}{$\begin{array}{l}\text { Moratio and } \\
\text { others, } 1988 \\
\text { Atwater and } \\
\text { others, } 1986\end{array}$} & \multirow{2}{*}{$\begin{array}{r}\text { Degradatlon } 2 \\
\text { began about } \\
190 \text { years ago }\end{array}$} \\
\hline & & Tulare Lake & Procipitation & & \\
\hline 124 & Treo-Ping & $\begin{array}{l}\text { Bristlecone Pine } \\
\text { Foxtail PIne }\end{array}$ & $\begin{array}{l}\text { Incroase in } \\
\text { Precipitation }\end{array}$ & $\begin{array}{l}\text { Schumm and } \\
\text { Hadley. } 1957\end{array}$ & $\begin{array}{l}\text { Aggradation } 3 \\
\text { began about } \\
97 \text { years ago }\end{array}$ \\
\hline 80 & Treo-Ring & $\begin{array}{l}\text { Bristlecone Pine } \\
\text { Foxtall Pine }\end{array}$ & $\begin{array}{l}\text { Decreaso in } \\
\text { Precipitation }\end{array}$ & \multirow{2}{*}{$\begin{array}{l}\text { Schumm and } \\
\text { Hadley, } 1957\end{array}$} & \multirow{2}{*}{$\begin{array}{l}\text { No record } \\
\text { of impact }\end{array}$} \\
\hline 44 & Treo-Ring & $\begin{array}{l}\text { Bristlecone Pine } \\
\text { Foxtaif Pine }\end{array}$ & $\begin{array}{l}\text { Increase in } \\
\text { Precipitation }\end{array}$ & & \\
\hline
\end{tabular}


central-eastern California at Osgood Swamp, Balsam Meadow, Swamp Lake, lower Kings Canyon, Gabbott Lake, and Exchequer Meadow, this mid-Holocene climatic change at about 7000 years ago is expressed as a shift toward wetter and possibly warmer conditions (Moratto and others, 1988). In support of a midHolocene climatic change from drier to wetter conditions occurring in the vicinity of Los Gatos Creek is the high stand at about 8200 to 7600 years ago of Tulare Lake (located in the San Joaquin Valley about 10 miles southeast of the Los Gatos CreekHighway 5 crossing) (Marchand, 1977; Atwater and others, 1986).

A general climatic change to cooler and wetter conditions was recorded in central and central-eastern California as occurring at about 3000 years ago (Moratto and others, 1988). Pollen data from Osgood Swamp (Adam, 1967), Dinkey and Exchequer Meadows (Davis, 1986; Wood, 1975), and Balsam Meadows (Davis and others, 1985) support a trend toward cooler and wetter conditions about 3000 years ago. Similarly, a change to cooler and wetter conditions lasting from 3000 to 1400 years ago is inferred by Scuderi (1987) from tree-ring records of foxtail pine in the south-central Sierra Nevada. Tree-ring records of bristlecone pine in southeastern California by LaMarche (1974) likewise indicate cool and wet conditions from 3300 to 2500 years ago. Meadow stratigraphy from Osgood Swamp, Gabbott and Tule Lakes, Harden Pond, and Balsam, Dinkey, Upper Cabin, and Exchequer Meadows located in the central Sierra Nevada show an increase in organic content and a decline in tree macrofossils at about 3000 years ago which is interpreted as indicating more moist conditions (Moratto and others, 1988).

The climate in central and central-eastern California changed to more dry and warm conditions about 1500 years ago. This is evidenced in the bristlecone pine and foxtail pine tree-ring records, in generally drier conditions in Sierra Nevada meadows, and in pollen records from Tule Lake (Moratto and others, 1988).

About 700 years ago the climate reversed to a generally cooler and wetter climate. This is evidenced by the bristleccne and foxtail pine tree-ring records, which reflect increasing moisture from 800 to 200 years ago, and in Sierra Nevada meadow stratigraphy which indicates wet conditions during this time (Moratto and others, 1988). 
Another climatic change toward warmer and drier conditions 200 years ago is indicated by the bristlecone and foxtail pine tree-ring records. Also, tree-ring records by Schulman (1945) and Fritts and Gordon (1982) indicate drought conditions during the calender years 1760 to 1820 . In support of the tree-ring data, stumps and erect branching trunks of pre-Gold Rush willows at low elevation in Tulare Lake indicate low lake levels during this time (Atwater and others, 1986). Finally, tree-ring data indicate a wet period between the calender years 1826 and 1870, a dry period between 1870 and 1906, and a wet period between 1906 and 1925 (Schumm and Hadley, 1957).

\section{Stream Response to Climatic Change}

The response of fluvial systems to climatic change depends strongly on the type of climate in the study area (Schumm, 1977). The climate in the Coalinga area is considered arid as can be shown with a 19 year record of mean annual temperatures and annual precipitations (table 6; Department of Commerce (NOAA), 1983; Waananen, 1969). Schumm (1977) defines an arid climate as one in which the mean annual temperature is greater than $15.6^{\circ} \mathrm{C}$ and the annual precipitation is 25.4 centimeters or less. The Meteorological Glossary (1944, page 17) defines an arid climate as one in which the annual precipitation in centimeters is less than $R$ where $R=2 t$ and $t$ is the mean annual temperature in degrees Celsius. In the Coalinga area, using a 19 year average of mean annual temperatures and annual precipitations, $\mathrm{t}=17.3^{\circ} \mathrm{C}, \mathrm{R}=34.6$, and the annual precipitation is 21.13 centimeters. This precipitation is less than $\mathrm{R}$ which designates the climate as arid. In only the years 1969 and 1978 out of the 19 years did the annual precipitation exceed that of an arid climate.

In arid regions, such as the Coalinga area, Schumm (1977, p. 29, 44-46) proposes that shifts in the climate from a warm and dry period to a cooler and wetter period cause a boost in sediment-transport capacity (runoff) without greatly increasing the effectiveness of vegetation in preventing drainage-basin erosion, with the end result of aggradation occurring. In contrast, for shifts to a warmer and drier climate from a cold and wet one, degradation will occur. If the climate in the Coalinga area was non-arid or semi-arid, then the response of the fluvial system to climatic changes would not be as simple as that stated above. If the climate in a 
Table 6: Annual precipitation and mean annual temperature record for the Coalinga area from 1962 to 1981 (Department of Commerce, 1983; Waananen, 1969). Using the Meterological Glossary (1944) definition of an arid climate, climate is arid when annual precipitation is less than $R$.

\begin{tabular}{|c|c|c|c|c|}
\hline Year & $\begin{array}{c}\text { Annual } \\
\text { Precipitation } \\
\text { (cm) }\end{array}$ & $\begin{array}{c}\text { Mean Annual } \\
\text { Temperature } \\
\text { (t, celsius) }\end{array}$ & $\begin{array}{c}\mathrm{R} \\
(\mathrm{R}=2 \mathrm{t})\end{array}$ & $\begin{array}{c}\text { Arid } \\
\text { Climate } \\
\text { Designation }\end{array}$ \\
\hline 1962 & 20.37 & 16.74 & 33.48 & Arid \\
1965 & 25.68 & 17.18 & 34.36 & Arid \\
1966 & 17.32 & 17.4 & 34.80 & Arid \\
1968 & 17.50 & 17.4 & 34.80 & Arid \\
1969 & 34.93 & 17.24 & 34.48 & Not Arid \\
1970 & 20.19 & 17.9 & 35.80 & Arid \\
1971 & 12.01 & 16.85 & 33.70 & Arid \\
1972 & 11.71 & -- & -- & Arid \\
1973 & 25.93 & 17.24 & 34.48 & Arid \\
1974 & 20.65 & 17.74 & 35.48 & Arid \\
1975 & 13.21 & --- & -- & Arid \\
1976 & 24.87 & --- & -- & Arid \\
1977 & 17.96 & 17.35 & 34.70 & Arid \\
1978 & 39.01 & 16.79 & 33.58 & Not Arid \\
1979 & 15.77 & --- & -- & Arid \\
1980 & 24.51 & --- & -- & Arid \\
1981 & 17.81 & 17.96 & 35.92 & Arid \\
\hline
\end{tabular}


semi-arid environment were to change from warm and dry to cool and wet, vegetation in the area might instead, effectively prevent erosion in the drainage basin and promote degradation in the main stream. However, because the Coalinga area contains an arid climate, the model used for the response of the fluvial system to climatic changes is that of the arid model. The following is a detailed correlation between changes in the Holocene climate in California and the degradational and aggradational episodes of Los Gatos Creek.

Aggradation 1. Aggradation 1 occurred sometime before 7735 years ago and lasted until about 6615 years ago. It correlates with the mid-postglacial increase in temperature and increase in precipitation about mid-Holocene (about 7000 years ago) recorded at Osgood Swamp, Balsam Meadow, Swamp Lake, lower Kings Canyon, Gabbott Lake, and Exchequer Meadow. Nearer to Los Gatos Creek, this change in climate is reflected in the rise in the level of the Tulare Lake to the high stand at about 8200 to 7600 years ago. This high stand would not only represent a change in the climate, but would also indicate a rise in the water table, which would effectively raise the base level of the creek. The creek would respond to this higher base level by aggrading in order to restore its gradient to prehigh-stand values (see Gradient below under Internal Variables).

Degradation 1. Degradation 1 occurred sometime before 6370 years ago and possibly is still continuing today upstream of Coalinga. It does not appear to correlate with any noted climatic change in California. Perhaps this degradation indicates a local decrease in the precipitation in the Coalinga area, or, more likely, this degradation was probably caused by changes in the internal variables of the fluvial system (see Internal Variables below).

Aggradation 2. The vigorous aggradation that resulted in the deposits of Fill 2 began about 4500 years ago near locality 86-6 and possibly continues today upstream of Coalinga. Like Degradation 1, this episode also does not appear to correlate with any noted climatic change in California and was instead probably caused by changes in the internal variables. An exception is the aggradation resulting in the upper part of Fill 2 (unit $\mathrm{H}$ ) which marks a dramatic increase in depositional rates about 500 years ago. Atwater and others (in press) have 
attributed this to the change in climate about 700 years ago, from a warm and dry period to a cool and wet period in south-eastern California, as recorded in the bristlecone-pine records of LaMarche (1974).

The thickest part of the Fill 2 is at locality 86-6 just upstream of the Guijarral Hills and downstream of the confluence with Jacalitos Creek; upstream and downstream of this locality the fill decreases in thickness. This anomaly in thickness might result from the additional sediment load of Jacalitos Creek combining with the sediment load of Los Gatos Creek causing overtopping of the banks downstream of Jacalitos Creek. Also, the Guijarral Hills tend to constrict the floodplain at this locality and act as a barrier to overland flow (this idea first proposed by Atwater and others, in press). In fact, the farthest downstream exposure of the channel facies deposits of Fill 2 is at the thickest part of the fill (locality 86-6), and might actually denote the starting point for the aggradation in the thalweg after which the locus of deposition migrated upstream. In this scenario, the Guijarral Hills and Jacalitos Creek actually magnify the effect of a climatic change by adding significant amounts of sediment to the already increased sediment load of Los Gatos Creek (this is discussed in more detail below under Internal Variables).

Degradation 2. Degradation 2 began about 190 years ago (calender year 1760) and possibly continues today upstream of Coalinga. It is correlative with the decrease in precipitation during the drought of 1760 to 1820 as recorded in tree-ring growth (Schulman, 1945; Fritts and Gordon, 1982), in the bristlecone tree-ring records (LaMarche, 1974), in the foxtail tree-ring records (Scuder, 1987), and as recorded by low lake levels in Tulare Lake during pre-Gold Rush time (Atwater and others, 1986).

Aggradation 3. Aggradation 3 began about 97 years ago (calender year 1853) and possibly continues today upstream of Coalinga and resulted in the terraces closest to the thalweg. It possibly correlates with the wet period of 1826 to 1870 as recorded in tree-ring growth (Schulman, 1945), but this is not an ideal fit, for the aggradational episode began 27 years after the change in climate. This may be because the aggradational episode actually began 27 years earlier than stated. 
This is not entirely unlikely as this episode is dated only by the depth to thalweg measurement in the 1853-54 survey. Alternatively, this episode may have been caused by changes in the internal variables of the system.

The numerous terraces with varying thicknesses at various elevations above the thalweg that apparently are older than the Fill 3 terraces probably resulted from a more complicated scenario than simply a climatic change. A combination of changes in all the following internal variables at various localities along the creek at various times might be able to explain the origin of these terraces, but to unravel the history of these changes would be a very complicated, if not impossible, task.

\section{Internal Variables}

Because a change in an external variable of a fluvial system necessarily causes changes in one or more internal variables of the system, all of the following internal variables have probably played a role in the aggradational and degradational history of Los Gatos Creek. However, in only two cases, Degradation 1 (6370 to 0 years ago) and Aggradation 2 (4500 to 0 years ago), are changes in the internal variables thought to be the sole cause. For these cases, a possibility is that changes in the internal variables resulted from disequilibriums introduced from the preceding episodes of degradation and aggradation. It is very probable, for example, that as Aggradation 1 proceeded upstream, the stream gradient became oversteepened at some point downstream of the aggrading reach. In order for the stream gradient to return to an equilibrium value, degradation may have occurred upstream of the oversteepened reach. This degradation would be Degradational episode 1. Likewise, Aggradation 2 might be explained as occurring in response to Degradation 1.

The following description of the internal variables of the fluvial system as described by Schumm (1961, and 1977) indicates how changes among them can initiate degradation or aggradation.

\section{Gradient}

If a stream is at grade, a sudden change in the gradient will cause the stream to respond by either aggrading or degrading until the gradient is returned to its equilibrium value. An increase in gradient along a particular reach of the stream 
will cause the stream to aggrade downstream of the reach and degrade upstream of the reach; a decrease in gradient along a particular reach would cause the opposite effect.

Meander Cut-off, A meander cut-off will decrease the sinuosity and thereby increase the gradient of the stream. This will result in degradation upstream of the reach and aggradation downstream of the reach, and may even trigger more cut-offs to occur due to bank erosion upstream and greater flood height downstream. Meander cut-offs have played a role in the dynamics of Los Gatos Creek as evidenced by meander cut-off deposits present in the exposed alluvium.

Localized Deposition in the Channel. Localized deposition in the channel will cause an anomaly in the stream gradient that will subsequently cause degradation downstream and aggradation upstream of the localized deposition in order to restore gradient to equilibrium. An example of localized deposition in Los Gatos Creek is in the thalweg and on the floodplain downstream of the confluence with Jacalitos Creek and upstream of the Guijarral Hills. This is because the added influx of sediment-laden discharge from Jacalitos Creek and from the Guijarral Hills would increase the sediment load past the carrying capacity of the stream and thereby initiate deposition and aggradation.

\section{Sediment Load}

Tributary With Higher Gradient. A tributary with a higher gradient than the main stream will carry a higher sediment load than the main stream, and when the two streams meet the increase in sediment load will cause deposition to occur downstream of the confluence. This in turn would decrease the gradient in the main stream just upstream of the confluence and could thereby initiate continued aggradation. All the small gullies and streams that flow off the Guijarral Hills and into Los Gatos Creek would qualify as tributaries having higher gradients than Los Gatos Creek.

Water Loss Through Channel Bottom. Water loss through the channel bottom might occur as water progresses down the channel. This in turn would increase the sediment load relative to discharge and initiate deposition. 
Slumping and Calving. Slumping and calving of the creeks' banks will cause an increase in the sediment load downstream of the locality where slumping occurred, and therefore initiate deposition. At Los Gatos Creek slumping is very common and probably has had a part in aggradational episodes and possibly even in the formation of some terraces.

Discharge

Tributary with Lower Gradient. A tributary with a lower gradient will carry a smaller sediment load than the main stream and when joining the main stream will cause an increase in discharge and a decrease in sediment load for the main stream. This increase in discharge over sediment load can initiate degradation. The tributary Zapato Chino Creek downstream of the Guijarral Hills has a lower gradient than that of Los Gatos Creek and may have played a role in degradation in this part of the system.

\section{Summary}

The degradational and aggradational episodes in the history of Los Gatos Creek have been caused by changes in both the external and internal variables of the fluvial system. These variables are interrelated and changes in either one of the external variables always caused changes in usually more than one internal variable. This complicated cause-and-effect relationship between the variables makes it difficult to attribute the cause of an aggradational or degradational episode to only one variable. 


\section{CONCLUSIONS}

Two out of the three aggradational episodes that resulted in the fluvial deposits of Los Gatos Creek were possibly caused by regional changes in the Holocene climate from dry to wet, and one out of the two degradational episodes that caused the major unconformities in the fluvial deposits possibly was caused by a regional change in the Holocene climate from wet to dry:

(1) Aggradational episode 1 began before 7735 years ago and lasted until about 6615 years ago, and resulted in the deposits of Fill 1. This episode possibly occurred due to a change in climate from dry to wet as evidenced by the high-stand shoreline of Tulare Lake (about 8200 to 7600 years ago), and as evidenced by pollen paleo-climatic records that indicate increased temperature and increased precipitation in the central and central-western Sierra Nevada at Osgood Swamp, Balsam Meadow, Swamp Lake, lower Kings Canyon, Gabbott Lake, and Exchequer Meadow (Moratto and others, 1988; Marchand, 1977; Atwater and others, 1986);

(2) Degradational episode 2 began about 190 years ago and possibly continues today. It may have occurred due to the change in climate from wet to dry about 190 years ago (the great California drought of 1760 to 1820; Moratto and others, 1988; Atwater and others, 1986);

(3) Aggradational episode 3 began about 97 years ago and possibly continues today. It resulted in the deposits of Fill 3 and possibly was caused by the change in climate marked by the increase in precipitation about 124 years ago (Schumm and Hadley, 1957). This aggradation was probably also caused in part from changes in the internal variables of the fluvial system.

Degradational episode 3 does not correlate with any known Holocene climatic change and was probably caused in part by a lowering of base level due to extensive groundwater-overdraft subsidence near the eastern edge of the study area. This subsidence occurred between the years 1949 and 1969; the degradation began about 1956 and is possibly continuing today. 
Degradational episode 1 and aggradational episode 2 also do not correlate with any known Holocene climatic changes. These episodes were probably caused by changes in the intrinsic or internal geomorphic variables of the fluvial system. Degradation 1 occurred between 6370 and 0 years ago and Aggradation 2 occurred between 4500 and 0 years ago. Stream gradient, sediment yield, and stream discharge could have been changed by non-climatic stream processes such as meander cut-offs. Changes such as this might be responsible for Degradation 1 and Aggradation 2. It is also possible that the preceding aggradational episode (Aggradation 1) caused changes in the internal variables. For example, an oversteepened stream gradient downstream of the aggrading reach might cause incision to begin.

Numerous terraces are present at various elevations above the thalweg that are probably older than the Fill 3 terraces. These older terraces probably resulted from a complicated combination of changes in internal variables at various sites along the creek at various times, coupled with climatic changes. The data to unravel the history of these changes, however, are not available. 


\section{REFERENCES}

Adam, D.P., (1967) Late-Pleistocene and Recent palynology in the central Sierra Nevada, California, in Cushing, E.J., and Wright, H.W., Jr, eds. Quaternary Paleoecology: New Haven, Yale University Press, p. 275-301.

Adam, D.P., Sims, J.D., and Throckmorton, C.K., (1981) 130,000-yr continuous pollen record from Clear Lake, Lake County, California: Geology, v. 9, p. 373-377.

Adam, D.P., and West, G.J., (1983) Temperature and precipitation estimates through the last glacial cycle from Clear Lake, California, pollen data: Science, v. 219, p. 168-170.

Allen, J.R.L., (1965) A review of the origin and characteristics of recent alluvial sediments: Sedimentology, v. 5, p. 89-191.

Allen, J.R.L., (1970) Physical processes of sedimentation: Allen and Unwin, London, 248 p.

Anderson, F.M., (1905) A stratigraphic study in the Mount Diablo Range of California: California Academy of Science Proceedings, ser. 3, v. 2, p. 155-248.

Atwater, B.F., Adam, D.P., Bradbury, J.P., Forester, R.M., Mark, R.K., Lettis, W.R., Fisher, G.R., Gobalet, K.W., and Robinson, S.W., (1986) A fan dam for Tulare Lake, California, and implications for the Wisconsin glacial history of the Sierra Nevada: Geological Society of America Bulletin, V. 97, no. 1, p. 97-109.

Atwater, B.F., Trumm, D.A., Tinsley III, J.C., Stein, R.S., Tucker, A.B., Donahue, D.J., Jull, A.J.T., and Payen, L.A., (in press) Alluvial plains 
and earthquake recurrence at the Coalinga Anticline, Alluvial Plains and Earthquake Recurrence at the Coalinga Anticline, in Rymer, M.J., and William, E.L., eds., U.S. Geological Survey Professional Paper 1487, Chapter 15.

Bartow, J.A., Cenozoic stratigraphy and geologic history of the Coalinga region, central California, in Rymer, M.J., and William, E.L., eds., U.S. Geological Survey Professional Paper 1487, Chapter 1.

Batchelder, G.L. (1980) A late Wisconsinan and early Holocene lacustrine stratigraphy and pollen record from the west slope of the Sierra Nevada, California: Sixth AMQUA abstracts and programs, p. 13.

Cole, K.L., (1983) Late Pleistocene vegetation of Kings Canyon, Sierra Nevada, California: Quaternary Research, v. 19, p. 117-129.

Collinson, J.D., (1978) Alluvial sediments, in Reading, H.G., ed., Sedimentary environments and facies: Elsevier, New York, p. 15-60.

Davis, O.K., Anderson, R.S., Fall, P.L., O'Rourke, M.K., and Thompson, R.S., (1985) Palynological evidence for early Holocene aridity in the southern Sierra Nevada, California: Quaternary Research, v. 24, p. 322332.

Department of Commerce, National Oceanic and Atmopheric Association (NOAA), Climatological Data - California, 1962-1983: Ashville, North Carolina, Environmental Data and Information Service, National Climatic Center.

Department of Commerce, National Oceanic and Atmopheric Association (NOAA), Storm Data, January 1971-March 1983: Ashville, North Carolina, Environmental Data and Information Service, National Climatic Center. 
Dibblee, T.W., JR., (1971) Geologic maps of the Coalinga, Joaquin Rocks, New Idria, and Priest Valley 15-minute quadrangles, California: U.S. Geological Survey Open-File report 71-87, scale 1:62,500.

Doeglas, D.J., (1962) The structure of sedimentary deposits of braided rivers: Sedimentology, v. 1, p. 167-190.

Fielding, E., Muawia, B., Brown, L., Oliver, J., and Kaufman, S., (1984) COCORP seismic profiles near Coalinga, California: Subsurface structure of the western Great Valley: Geology, v. 12, p. 268-273.

Fritts, H.C., and Gordon, G.A., (1982) Reconstructed annual precipitation for California, in Hughes, M.K., Kelly, P.M., Pilcher, J.R., and LaMarche, V.C., Jr., eds., Climate from tree rings: Cambridge, England, Cambridge University Press, p. 185-191.

Ireland, R.L., Poland, J.F., and Riley, F.S., (1984) Land subsidence in the San Joaquin Valley, California, as of 1980, in U.S. Geological Survey Professional Paper 437-I, p. I1-I93.

Kukal, Z., (1971) Geology of recent sediments: Academic Press, London and New York, 490 p.

LaMarche, V.C., Jr., (1973) Climatic variations inferred from treeline fluctuations in the White Mountains, California: Quaternary Research, v. 3, p. 632660.

LaMarche, V.C., Jr., (1974) Paleoclimatic inferences from long tree-ring records: Science, v. 183 , no., 4129 , p. $1043-1048$.

Lettis, W.R., (1982) Late Cenozoic stratigraphy and structure of the western margin of the central San Joaquin Valley, California: U.S. Geological Survey Open-File Report 82-526, 202p. 
Machin, J.H., (1948) Concept of the graded river: Geological Society of America Bulletin, v. 59, p. 463-512.

Mackey, E.M., and Sullivan, D.G., (1986) A 10000 year palynological and stratigraphic record from Gabbott Lake, Alpine County, California: Ninth Annual AMQUA Abstracts, p. 95.

Marchand, D.E., (1977) The Cenozoic history of the San Joaquin Valley and adjacent Sierra Nevada as inferred from the geology and soils of the eastern San Joaquin Valley, in Singer, M.J., ed., Soil development, geomorphology and Cenozoic history of the northeastern San Joaquin Valley and adjacent areas, California: American Society of Agronomy, Geological Society of America, Soil Science Society of America joint field section, guidebook, University of California Press, Davis, p. 39-50.

McGarr, A., Mueller, C., Fletcher, J.B., and Andrews, M., (in press) Groundmotion and source parameters of the Coalinga earthquake sequence, in Rymer, M.J., and William, E.L., eds., U.S. Geological Survey Professional Paper 1487, Chapter 12.

Meteorological Glossary, Air Ministry (1944): third edition, London.

Moratto, M.J., Tordoff, J.D., and Shoup, L.H., (1988) Culture change in the central Sierra Nevada 8000 B.C. - A.D. 1950: Final report of the New Melones archaeological project, v. 9, chapter 2, National Park Service.

Munn, T.R., Busacca, A.T., and Trott, K.E., (1981) California aqueduct sedimentation study for the Arroyo Pasajero and tributary watersheds: Sacramento, California Department of Conservation special report, $72 \mathrm{p}$. 
North American Commission on Stratigraphic Nomenclature, (1983) North American Stratigraphic Code: The American Association of Petroleum Geologists Bulletin, v. 67, no. 5, p. 841-875.

Obradovich, J.D., Naeser, C.W., and Izett, G.A., (1978) Geochronology of late Neogene marine strata in California: Stanford University Publications, Geological Science, v. 14, p. 40-41.

Ouchi, S., (1983) Response of alluvial rivers to active tectonics (Ph.D. Thesis): Colorado State University, Fort Collins, Colorado, 205 p.

Pearson, G.W., Dilcher, J.T., Baillie, M.G.L., Corbett, D.M., and Qua, F., (1986) High-precision ${ }^{14} \mathrm{C}$ measurement of Irish oaks to show the natural ${ }^{14} \mathrm{C}$ variations from $\mathrm{AD} 1840$ to $5210 \mathrm{BC}$ : Radiocarbon, v.28, no. $2 \mathrm{~B}, \mathrm{p}$. 911-934

Pearson, G.W., Stuiver, and Minze, (1986) high-precision calibration of the radiocarbon time scale, 500 to $2500 \mathrm{BC}$ : Radiocarbon, v. 28 , no. $2 \mathrm{~B}$, p. 839-862.

Rymer, M.J., Harms, K.K., Lienkaemper, J.J., and Clark, M.M., (in press) Surface rupture on the Nunez fault during the Coalinga earthquake sequence, in Rymer, M.J., and William, E.L., eds., U.S. Geological Survey Professional Paper 1487, Chapter 16.

Schulman, E., (1945) Tree-ring hydrology of the Colorado River basin: University of Arizona Bulletin, v. 16, no. 4, p. 51.

Schumm, S.A., (1960) The effect of sediment type on the shape and stratification of some modern fluvial deposits: American Journal of Science, v. 258, p. 177-184. 
Schumm, S.A., (1961) Effect of sediment characteristics on erosion and deposition in ephemeral-stream channels, U.S. Geological Survey Professional Paper 352-C, $70 \mathrm{p}$.

Schumm, S.A., (1977) The fluvial system: John Wiley and Sons, 338 p.

Schumm, S.A., and Hadley, R.F., (1957) Arroyos and the semiarid cycle of erosion, American Journal of Science, v. 255, p. 161-174.

Scuderi, L.A., (1987) Late Holocene upper timberline variation in the southern Sierra Nevada: Nature, v. 325, p. 242-244.

Sims, J.D., Adam, D.P., and Rymer, M.J., (in press) Late Pleistocene stratigraphy and palynology of Clear Lake: in U.S. Geological Survey Professional Paper 1141.

Stein, R.S., (1985) Evidence for surface folding and subsurface fault slip from geodetic elevation changes associated with the 1983 Coalinga, California earthquake, in Rymer, M.J., and Ellsworth, W.L., eds., U.S. Geological Survey Open-File Report 85-44, p.225-253.

Stein, R.S., and King, G.C.P., (1984) Seismic potential revealed by surface folding: 1983 Coalinga, California, earthquake: Science, v. 224, no. 4651 , p. $869-872$.

Stuiver, Minze, and Pearson, G.W., (1986) High-precision calibration of the radiocarbon time scale, $\mathrm{AD} 1950$ to $500 \mathrm{BC}$ : Radiocarbon, v. 28 , no. $2 \mathrm{~B}$, p. 805-838.

Sullivan, D.G., (1985) Report on the preliminary results of pollen and sediment analysis, Gabbott Lake, Alpine County, California, Ms. submitted to Peak and Associates, Sacramento. 
Tyler, N., and Ethridge, F.G., (1983) Depositional setting of the Salt Wash Member of the Morrison Formation, Southwest Colorado: Journal of Sedimentary Petrology, v. 53, no. 1, p. 0067-0082.

Walker, R.G., (1963) Distinctive types of ripple-drift cross-lamination: Sedimentology, v. 2, p. 173-188.

Wannanen, A.O., (1969) Flood of January and Feburary 1969 in central and southern California: U.S. Geological Survey, Water Resources Division, Open File Report.

Watts, W.L., (1894) The gas and petroleum yielding formation of the Central Valley of California: California State Mining Bureau Bulletin, v. 3, 100 p.

Weldon, R.J., (1985) Late Cenozoic geology of Cajon Pass; implications for tectonics and sedimentation along the San Andreas fault: Pasadena, California Institute of Technology, unpublished Ph.D. Thesis, $382 \mathrm{p}$.

Wentworth, C.M., and Zoback, M.D., (in press) Structure of the Coalinga region and thrust origin of the earthquake, in Rymer, M.J., and William, E.L., eds., U.S. Geological Survey Professional Paper 1487, Chapter 4.

West, G.J., unpublished reports on file at the Anthropological Research Facility, Sonoma State University, Rohnert Park, California.

Wood, S.H., (1975) Holocene stratigraphy and chronology of mountain meadows, Sierra Nevada, California: USDA Forest Service, Earth Resources Monograph, v. 4, San Francisco. 


\section{APPENDIX}

The measured sections of Los Gatos Creek are listed in numerical order in this appendix. See figure 2 for measured section localities. Each measured section has a width of approximately 5 meters and heights vary from 2.3 to 10.0 meters above the thalweg. Lithologic descriptions are given to the right of graphic representations of the measured sections. Radiocarbon dates are indicated to the left of the graphic logs. A diamond indicates a detrital origin for the charcoal deposit used in the radiocarbon determination and a circle indicates a burned-in-place origin for the charcoal deposit. The base of the sections are often covered by talus deposits.

\section{Section 1}

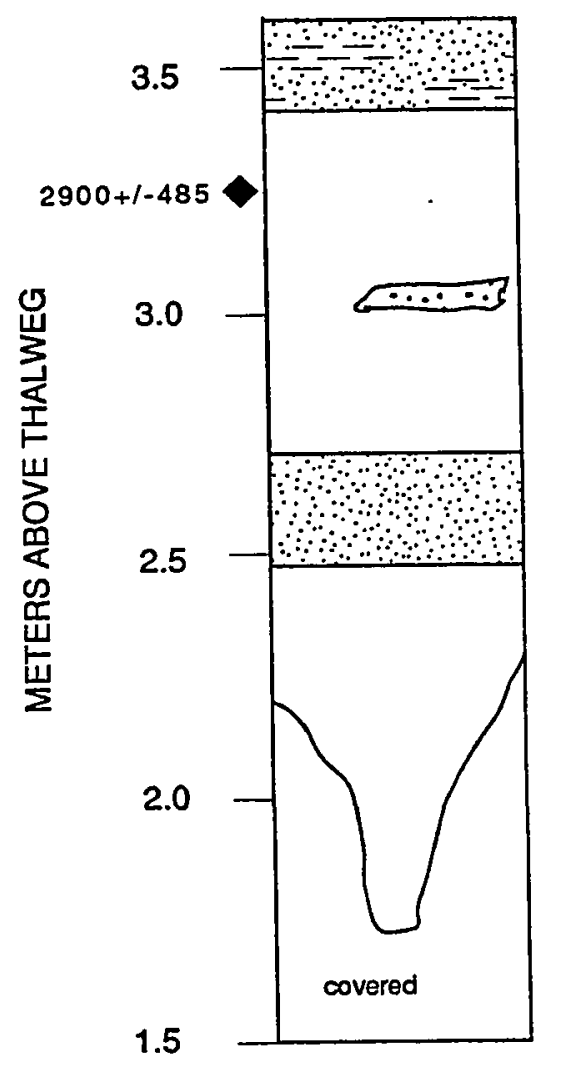

Silt and sand.

Silt with coarse sand lense.

Fine sand.

Mostly silt. 


\section{Section 1}

(continued from previous page)

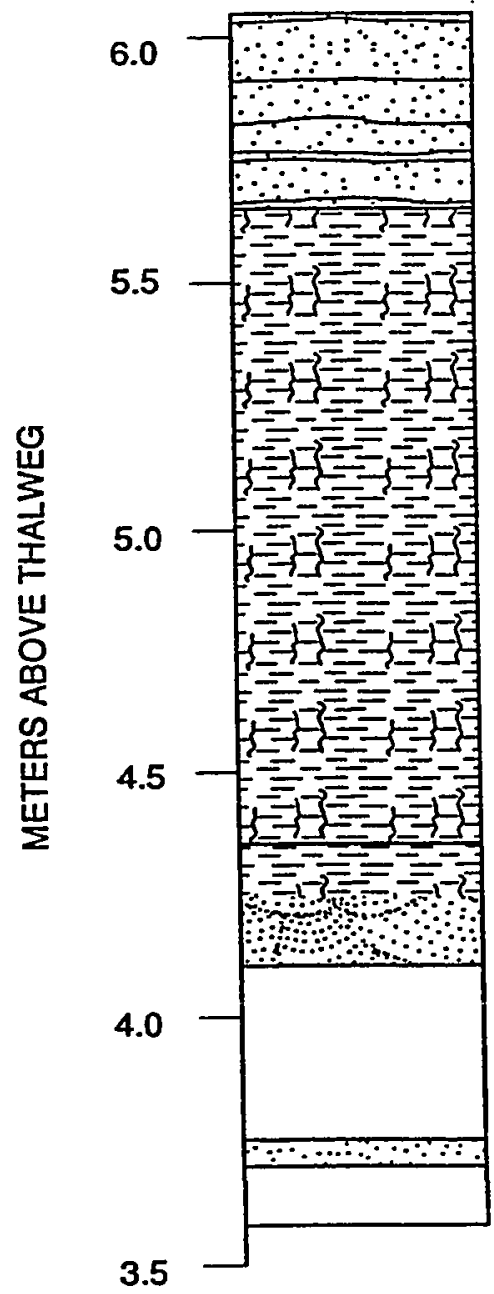

Silty very fine sand, more orless unlaminated but probably not bioturbated. Fine and coarse silt interlayered (layers about $1 \mathrm{~cm}$ thick). Possible hiatus where unlaminated silty sediments.

Mostly laminated silt.

Unlaminated silt with gypsum layer (mostly $2-5 \mathrm{~cm}$ thick). Color 2.5Y 4.5/4.

Very fine to fine sand. Stoss preserved, grades laterally into unlaminated silty very fine to fine sand.

Silty very fine sand. Indistinctly planar laminated. 2.5 Y $4.5 / 4$ (most coarse silt usually 2.5 Y $5 / 4$ ). 


\section{Section 1}

(continued from previous page)

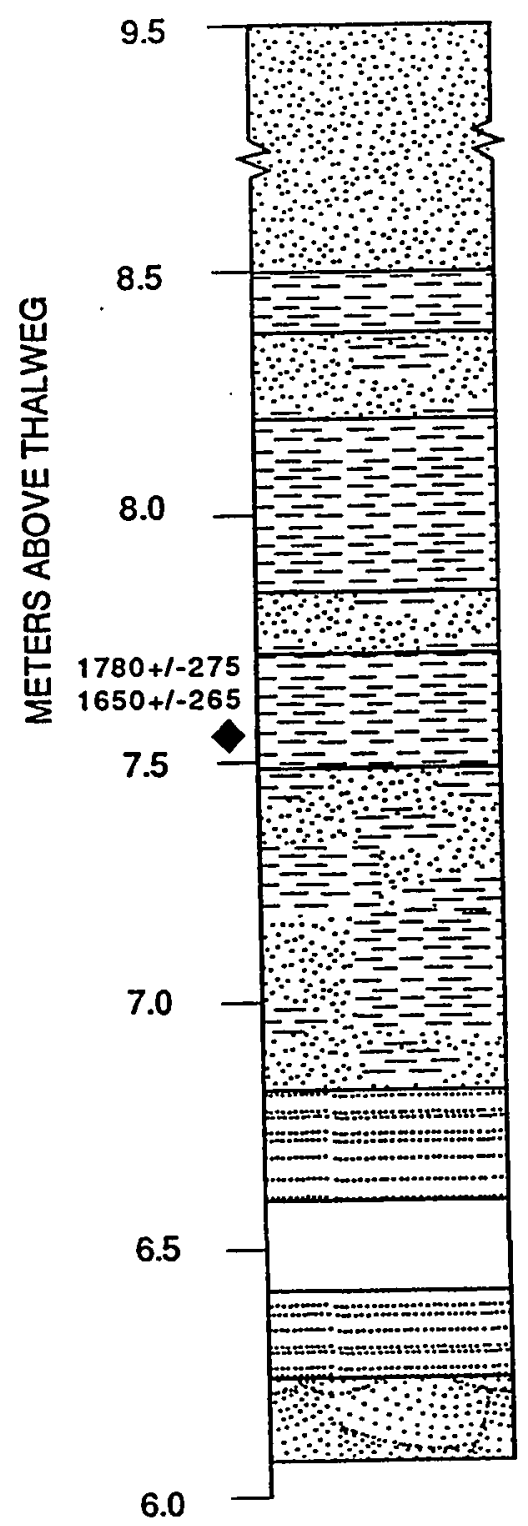

Mostly bioiturbated.

Mainly silt; dark.

Mainly very fine sand and coarse silt. (light)

Mainly silt. Dark in outcrop.

Mainly very fine sand and coarse silt; light.

Mainly silt. Dark in dry outcrop.

Mainly coarse silt with some very fine sand. Light in dry outcrop.

Mostly very fine sand. Well laminated.

Very fine to fine sand. Well laminated.

Cross laminated $(15 \mathrm{~cm}$ sets) fine sand. Break in slope at this point. 


\section{Section 2}

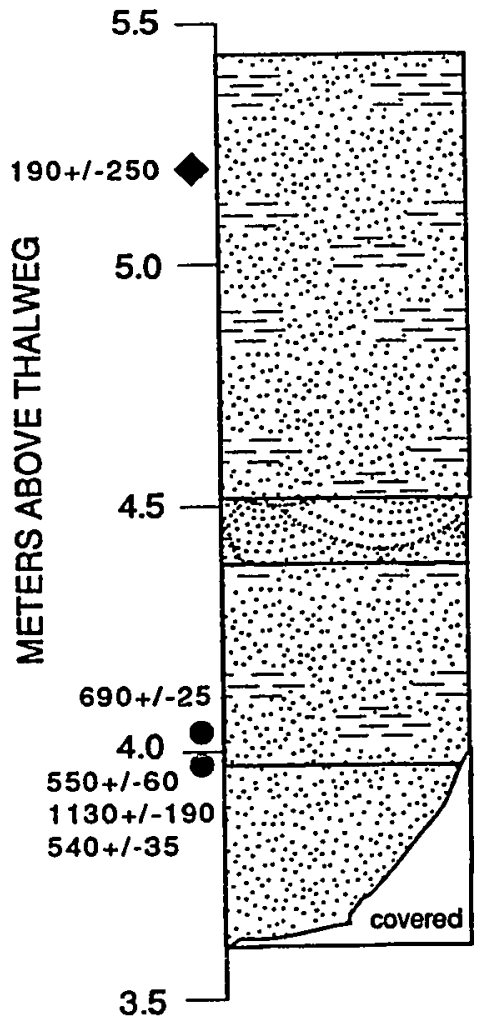

Well laminated to indistinctly laminated silt and minor very fine sand.

Very fine sand. Well cross laminated.

Interbedded very fine sand and sitt. Silt layers $1-15 \mathrm{~mm}$, mostly $10-30 \%$ disrupted.

Very fine to fine sand with much asbestos. Mostly planer laminated. Some silt interbeds. 


\section{Section 2}

(continued from previous page)

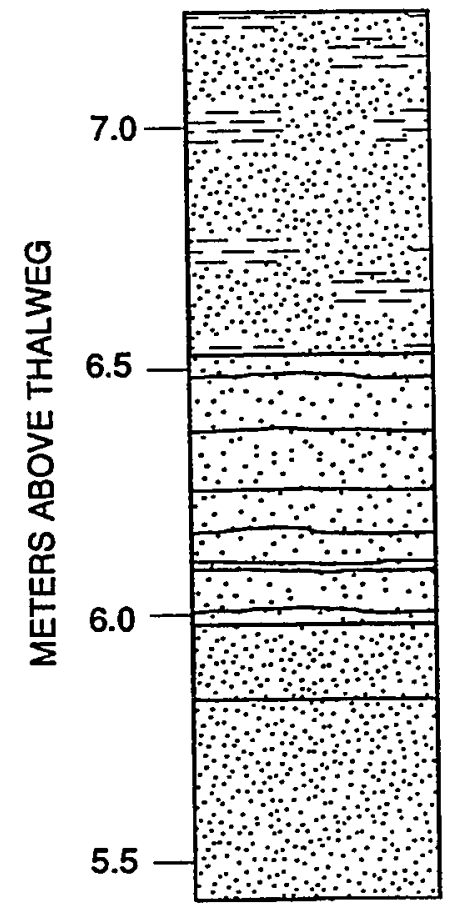

Laminated silt and laminated very fine sand $=70: 30 \%$.

Very fine sand and silt $=40: 60 \%$.

Planar laminated interbedded very fine sand and silt grading laterally to very fine and fine sand.

Unlaminated very fine sand with silt clasts $(2 \times 15 \mathrm{~cm})$. 


\section{Section 3}

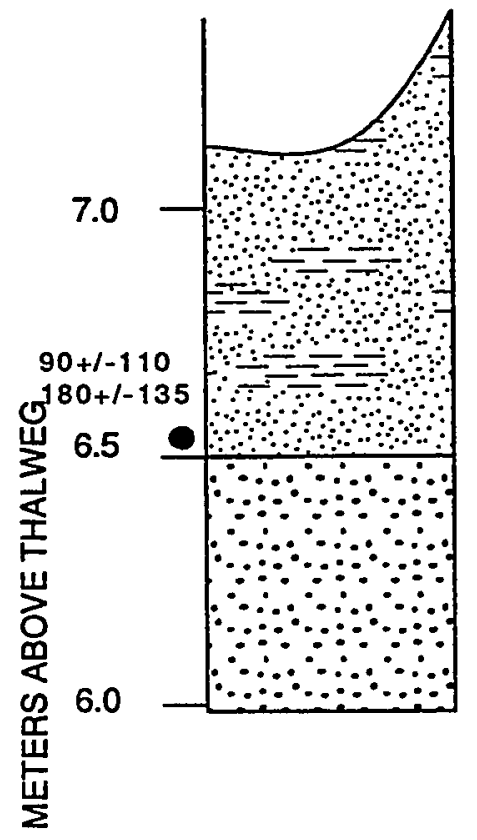

Top 0.4 meters bioturbated. Very fine sand interbedded with subordinate silt; sand:silt $=2: 1$. Much disruption of bedding, much asbestos.

Granular fine sand with $1 \%$ pebbles.

Planar laminated. 


\section{Section 3}

(continued from previous page)

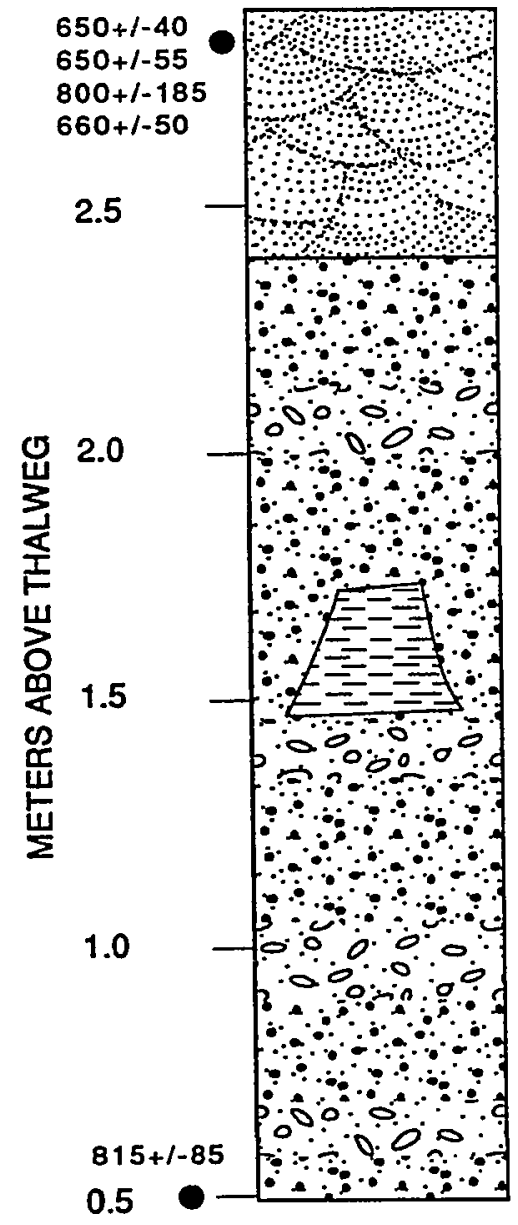

Very fine to tine sand. Cross laminated throughout. One $10 \mathrm{~cm}$ thick bed of rounded charcoal.

Coarse sand with gravel layers and one discontinuous bed of silt. 


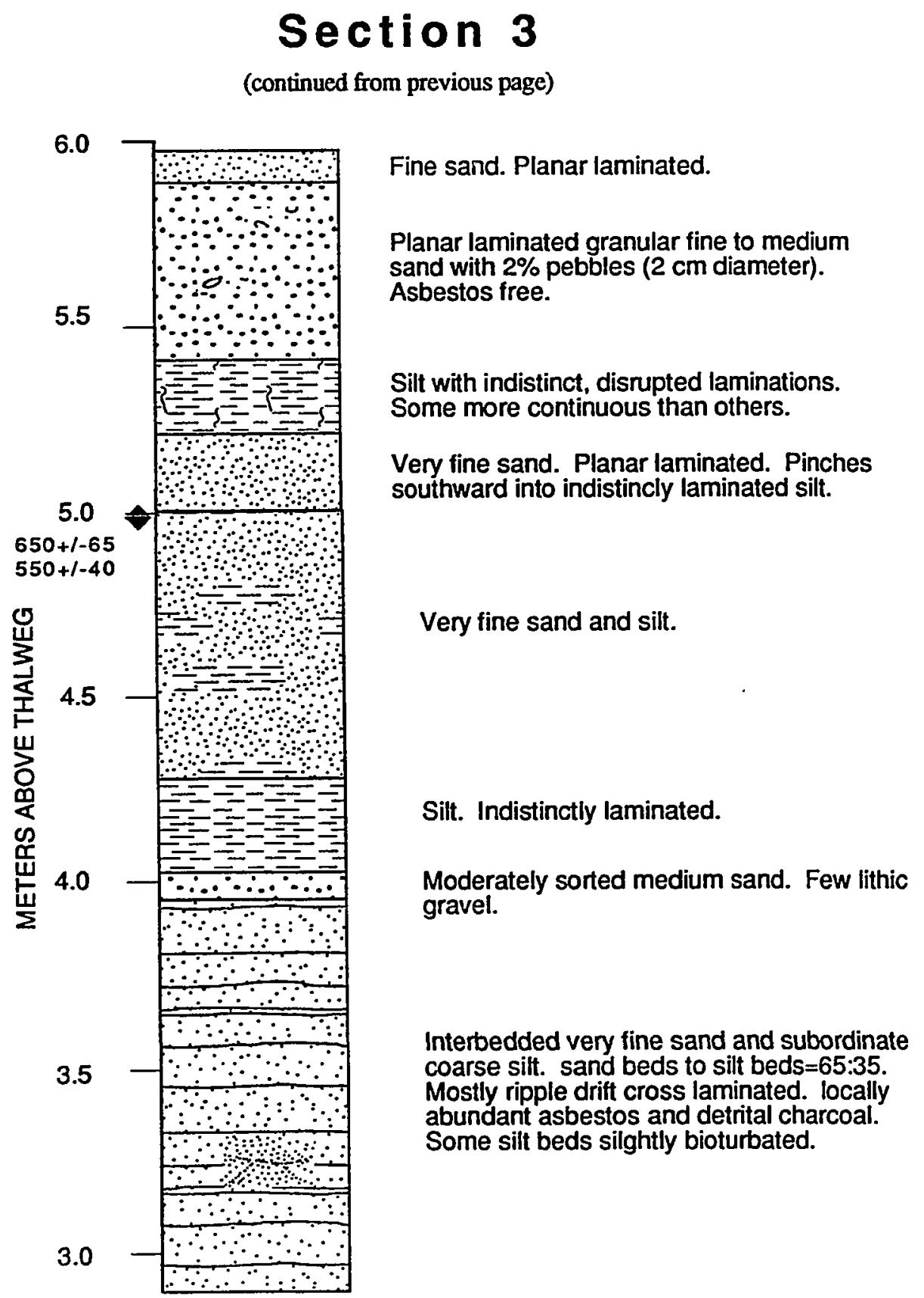




\section{Section 4}

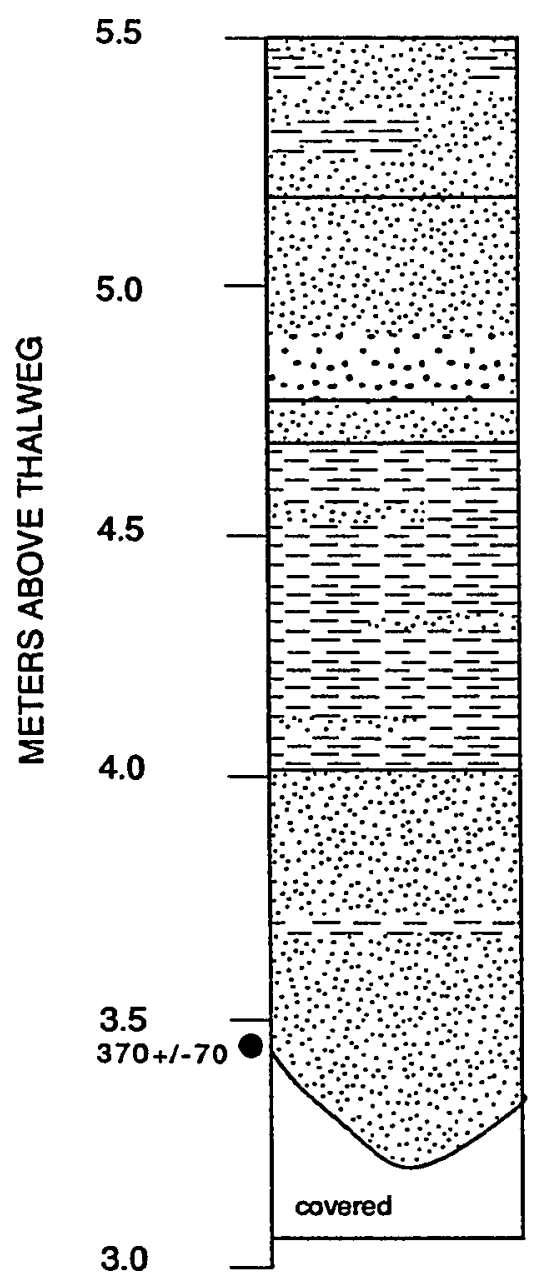

Unlaminated silty very fine sand.

Slightly granular medium to very fine sand (upward fining). Planar and cross laminated.

Very fine planar laminated sand.

Silt and subordinant very fine sand interbedded. Silt to sand $=4: 1$. Silt layers continuous to mostly bioturbated.

Very fine sand and minor coarse silt. Mostly well laminated. $5 \mathrm{~mm}$ thick charcoal and asbestos layer. 


\section{Section 7}

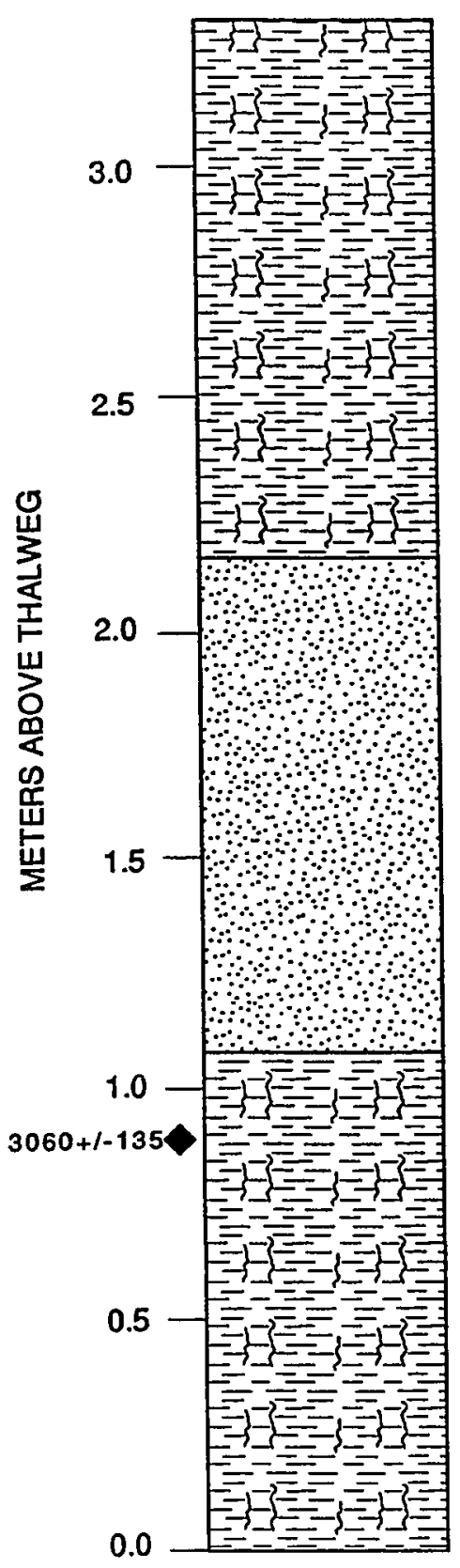

Medium silt. Very porous and cracked. Mottling of red and gray present. No structures - bioturbated.

Unstratified fine to very fine sand. Upward fining. Some root casts and asbestos flakes. Thin silt parting.

Medium to coarse silt. Mostly unstratified and bioturbated. Many root casts. Very porous. 


\title{
Section 7
}

\author{
(continued from previous page)
}

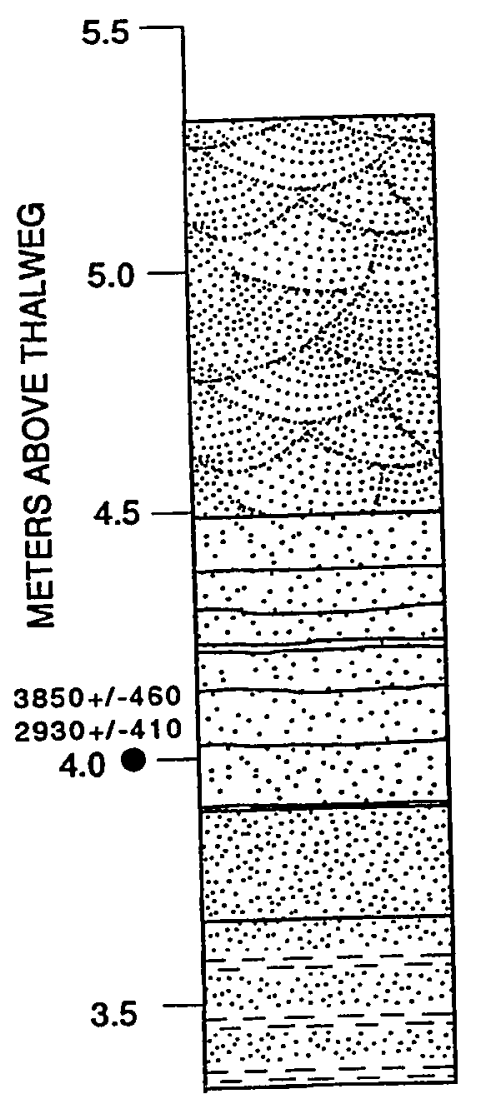

Very fine to fine cross laminated (stoss preserved and not preserved) sand.

Interbedded layers of coarse to fine silt and silty very fine to fine sand. Each upward fining sequence is about $10-15 \mathrm{~cm}$ thick.

Fine to very fine cross laminated sand.

Coarse to fine silt interbedded with silty very fine sand. Silt finely laminated. 


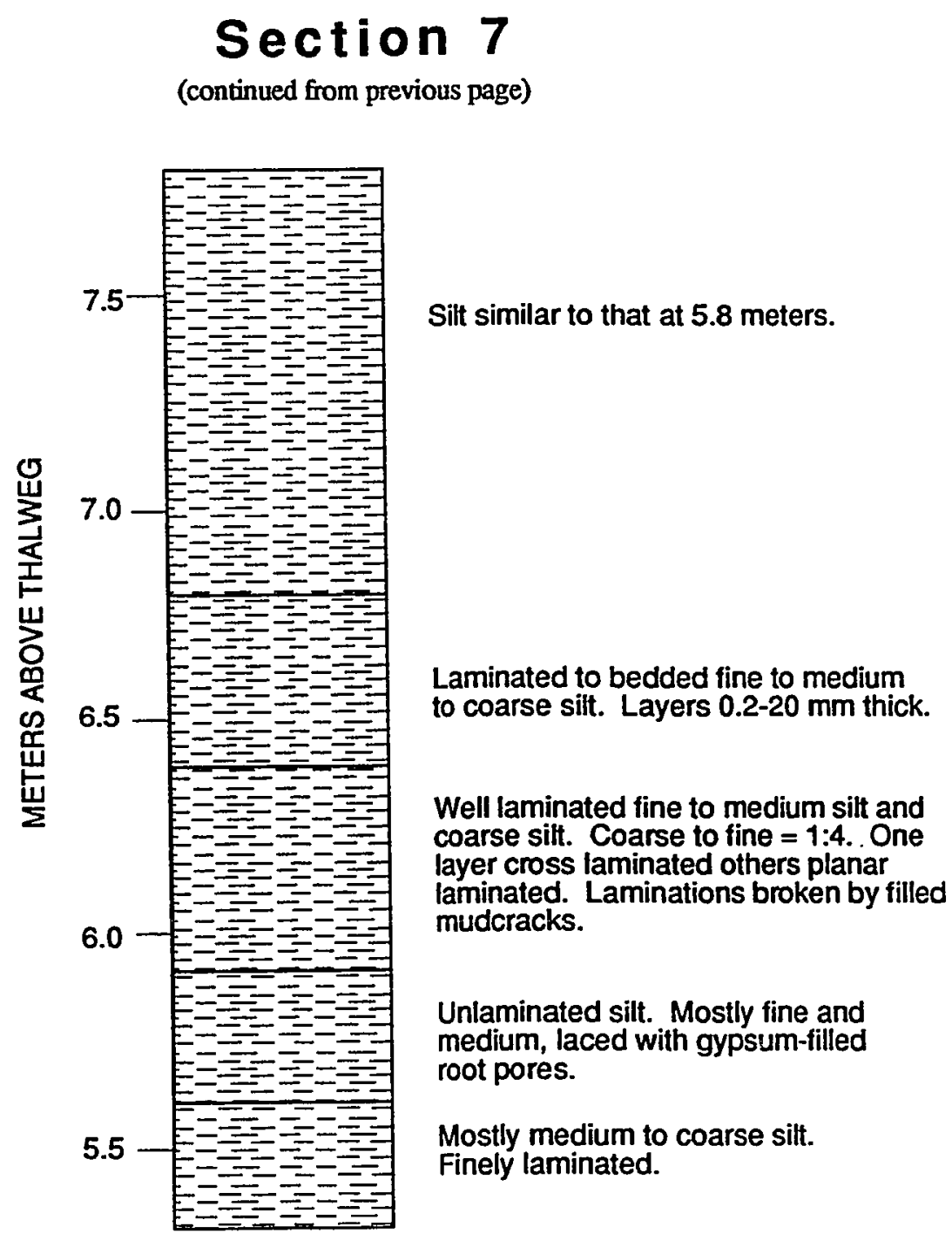




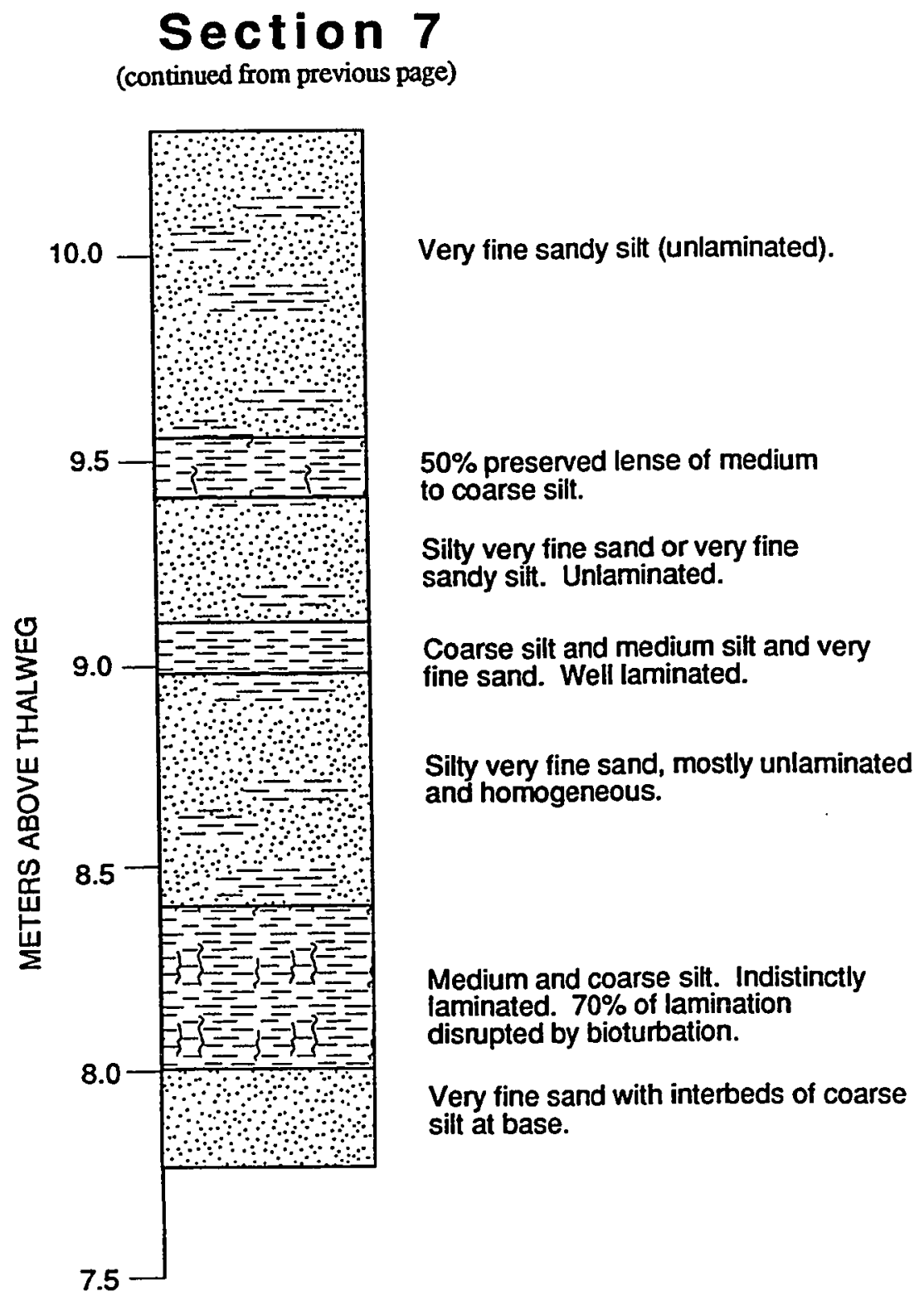




\section{Section 8}

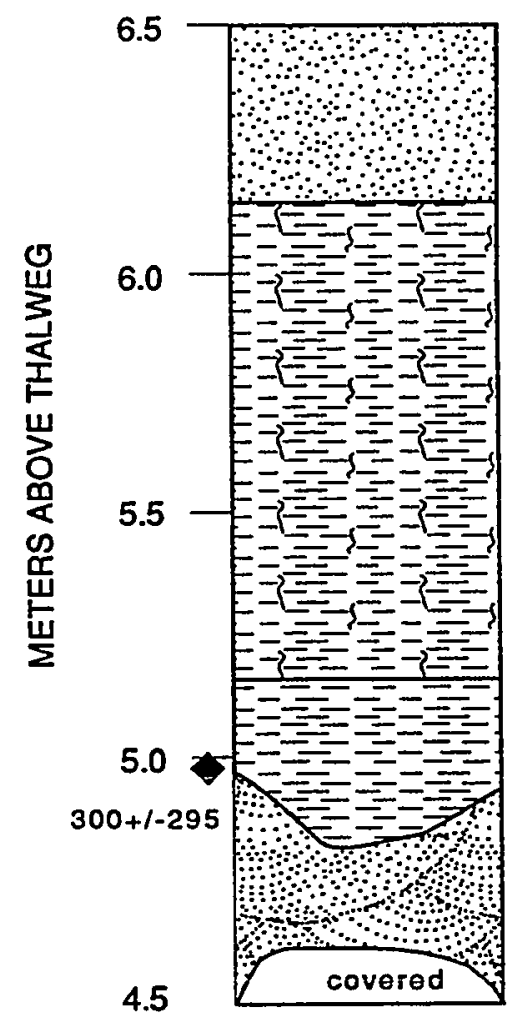

Fine sand.

Silty clay.

Sitty clay. Bottom of gully fill.

Cross bedded fine sand. 


\section{Section 8}

(continued from previous page)

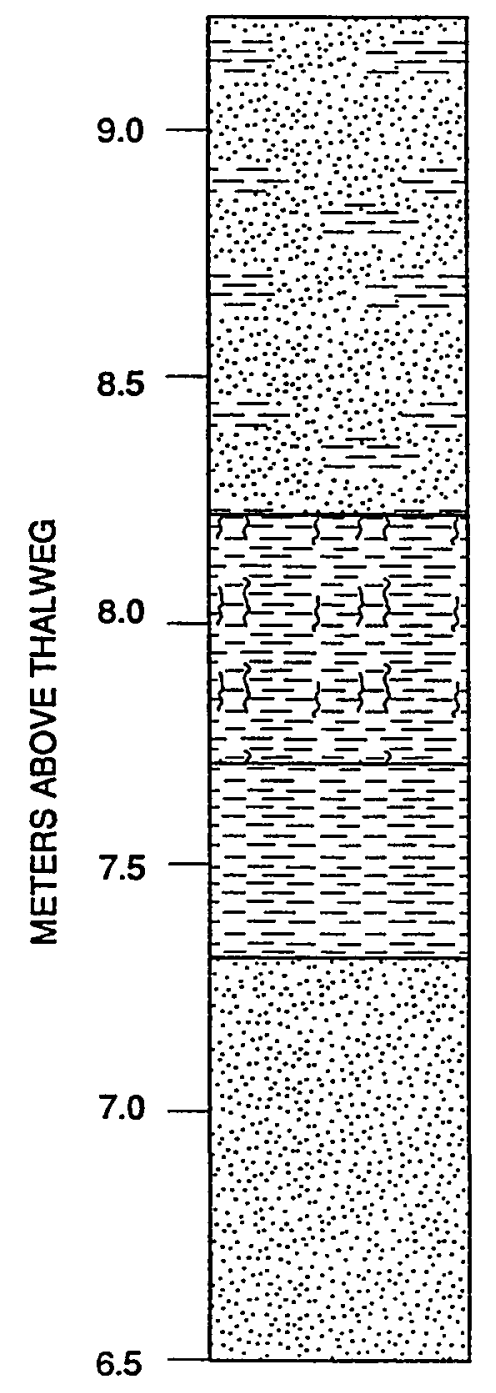

Silt and fine sand.

Silt with disrupted laminations.

Planar laminated silt.

Fine sand. 


\section{Section 9}

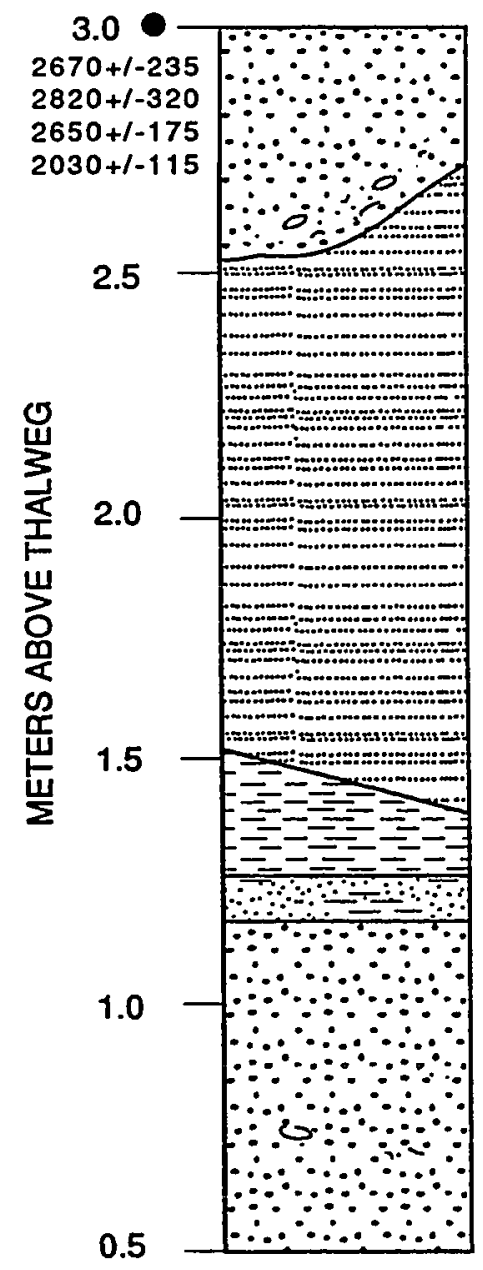

Fine to medium sand. Pebbly at base. Primary dip.

Primarily very fine sand. Minor very fine sandy silt. Mostly laminated.

Medium to coarse sitt (laminated).

Silty very fine sand. Unlaminated and homogeneous.

Slightly (1\%) pebbly fine to medium sand. 


\section{Section 9}

(continued from previous page)

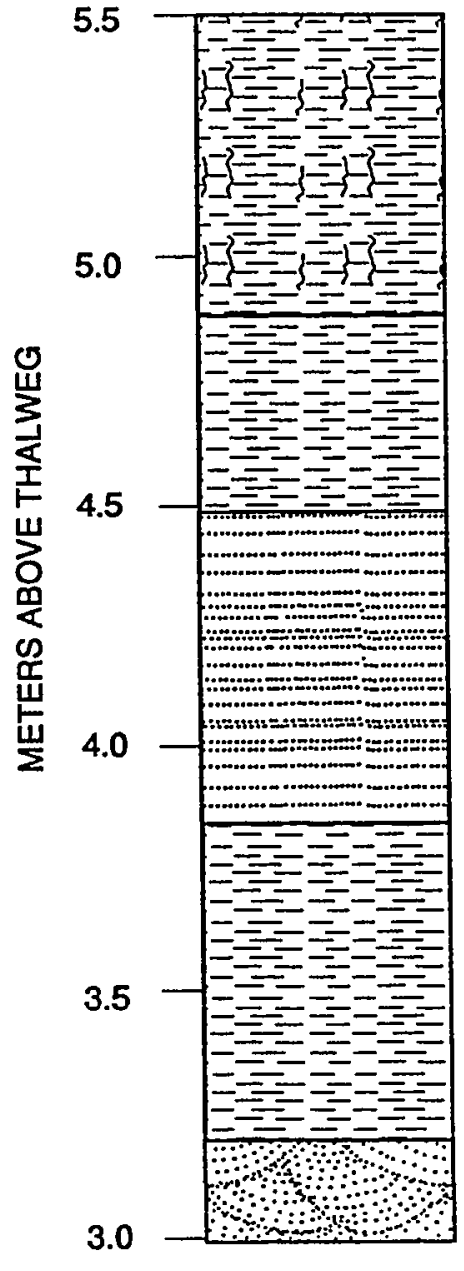

Mostly medium silt. Laminations

largely disrupted.

Coarse to medium silt. Laminations somewhat disrupted.

Mostly very fine sand. In part silty, mostly well laminated.

Mostly medium to coarse silt.

Very fine to fine, cross bedded, sand. Contains much asbestos and rounded charcoal. 


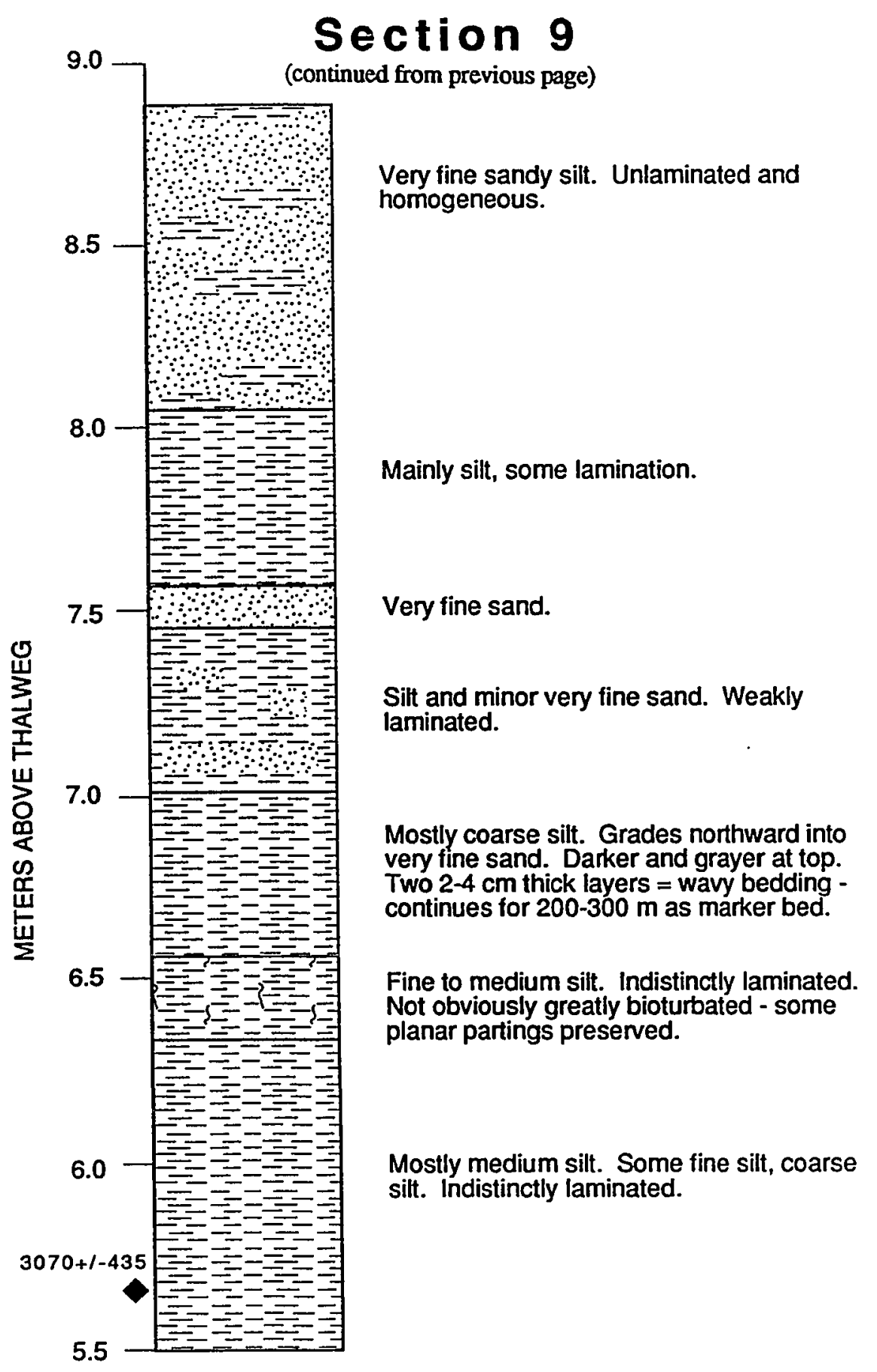




\section{Section 10}

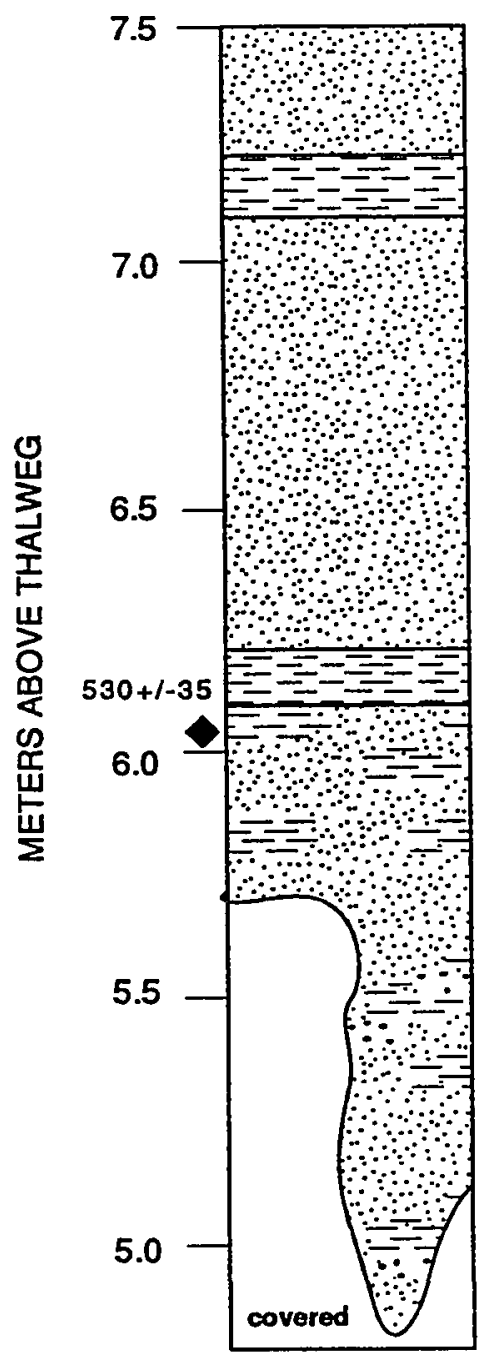

Very fine to fine sand with $10 \%$ silt rip-up clasts.

Coarse silt. Indistinctly laminated.

Silty very fine sand with $10-20 \%$ silt rip-up clasts. Unlaminated. Also few interbeds and lenses of well laminated coarse silt.

Coarse silt. Well laminated (planar).

Sand locally to 5YR 4/6 (usual 2.5Y 5/4) in difuse $1 \mathrm{~cm}$ zone with charcoal.

Predominately sand grades to silt with indistict lamination.

Very fine to fine sand with silty matrix. Many coarse silt clasts, some discontinuous lenses of well laminated very fine sand, coarse silt, and fine to medium sand. 


\section{Section 10}

(continued from previous page)

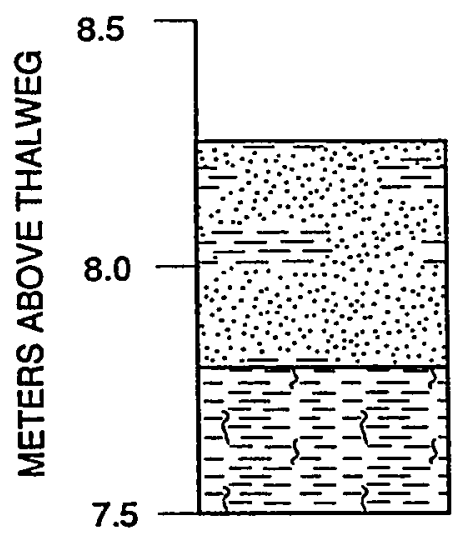

Silty sand, unlaminated; soil in approximately pristine condition?

Medium and subordinate coarse silt.

Laminae $25 \%$ disrupted, mostly along

finest silt layers. 


\section{Section 15}

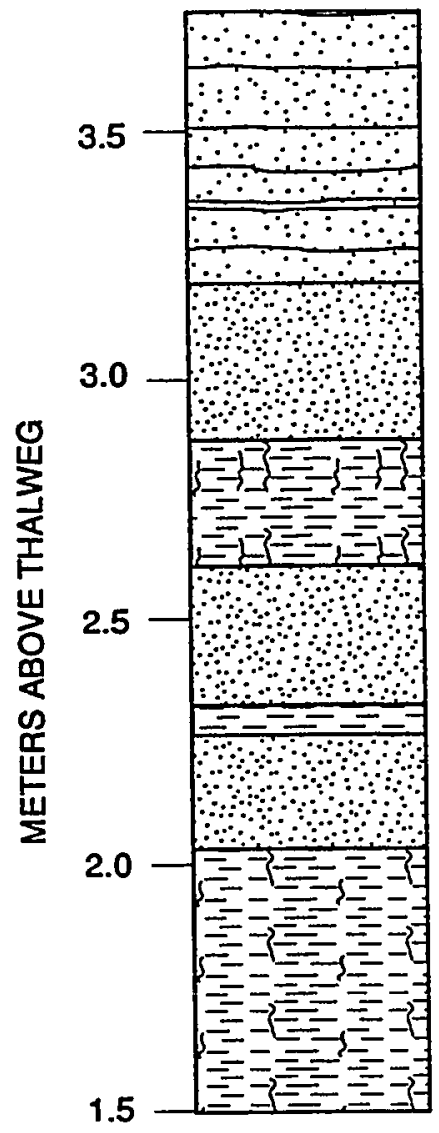

3-4 laminated sitt layers in fine sand matrix. Mudcracks common.

Very fine sand. Mudclasts and mudcracks common. Small lenses of coarse subrounded sand.

Coarse silt. 3-4 mudcracked layers. Unlaminated. Root marks common. Bioturbated.

Fine sand with mudclasts. No structures.

Finely laminated silt.

Fine sand with no evident structures.

Fine silt. Some laminations and some mudcracks. 


\section{Section 15}

(continued from previous page)

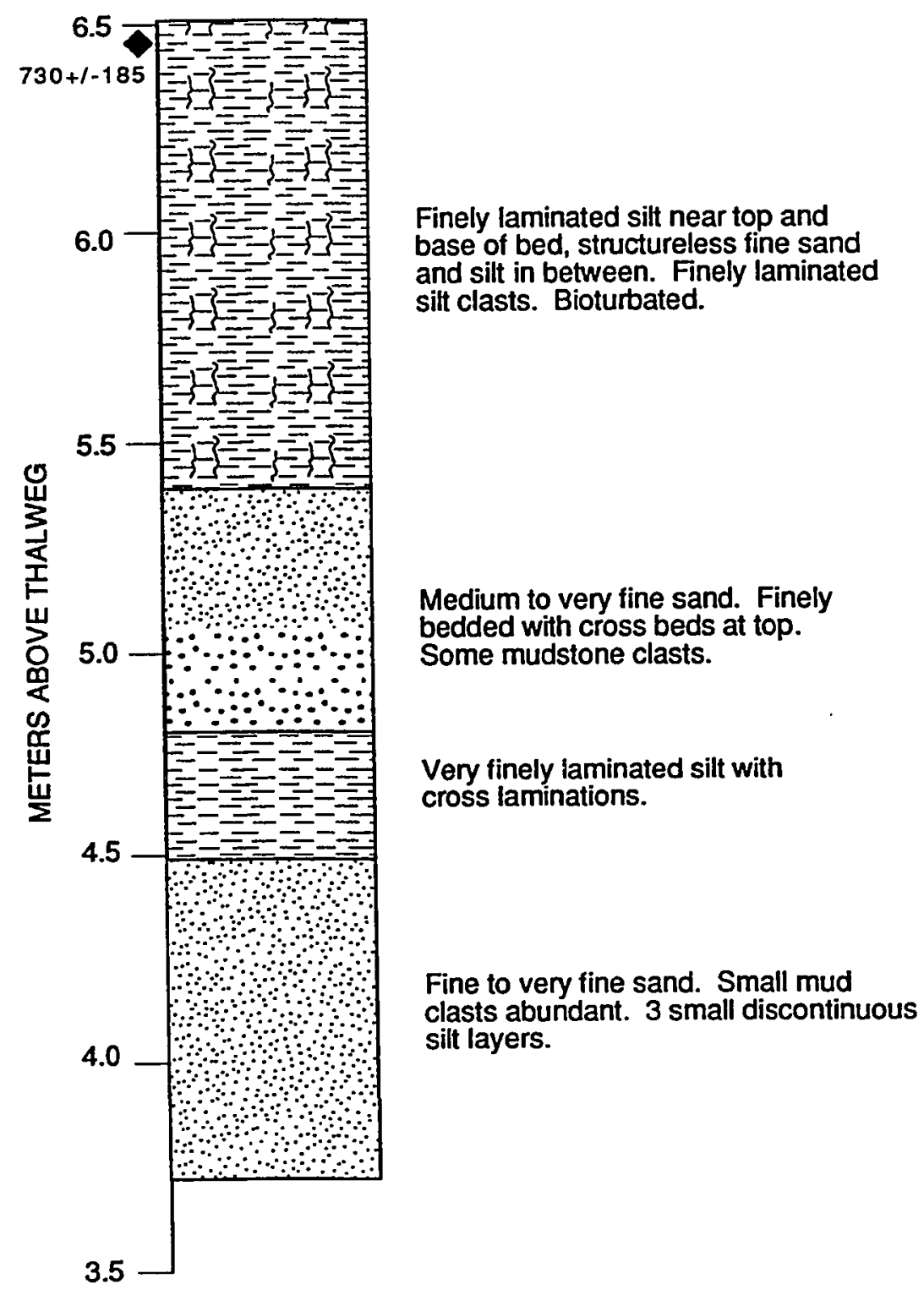




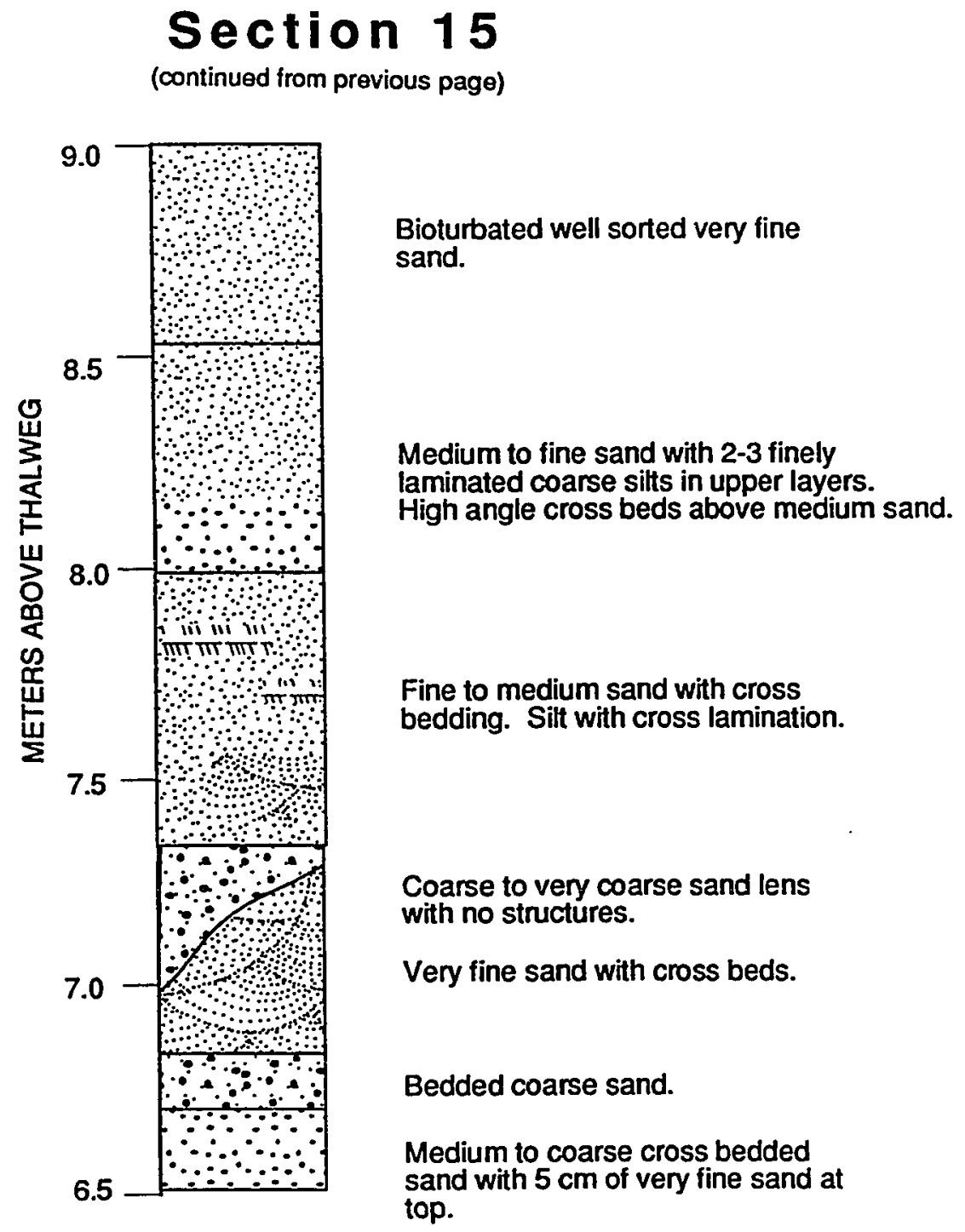




\section{Section 16}

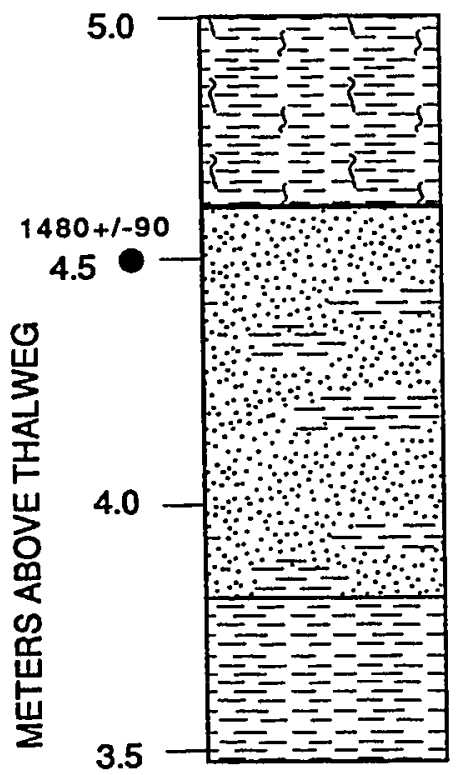

Silt. Laminations slightly disrupted.

Silty fine sand.

Sit. 


\section{Section 16}

(continued from previous page)

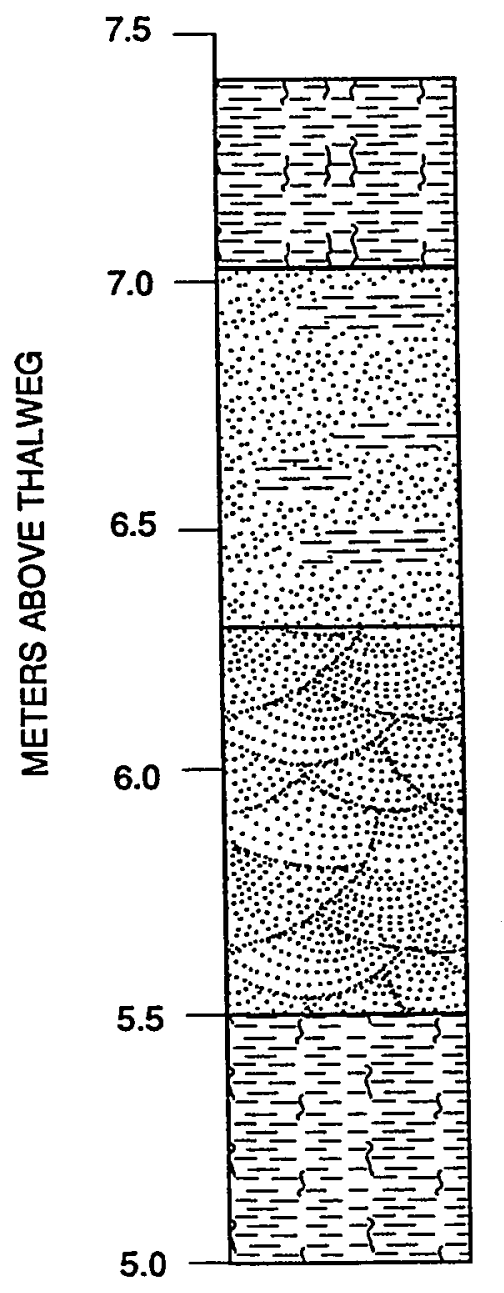

Top soil. Bioturbated silty sand.

Silty fine sand.

Cross bedded fine sand.

Silt. Laminations mostly disrupted. 


\section{Section 18}

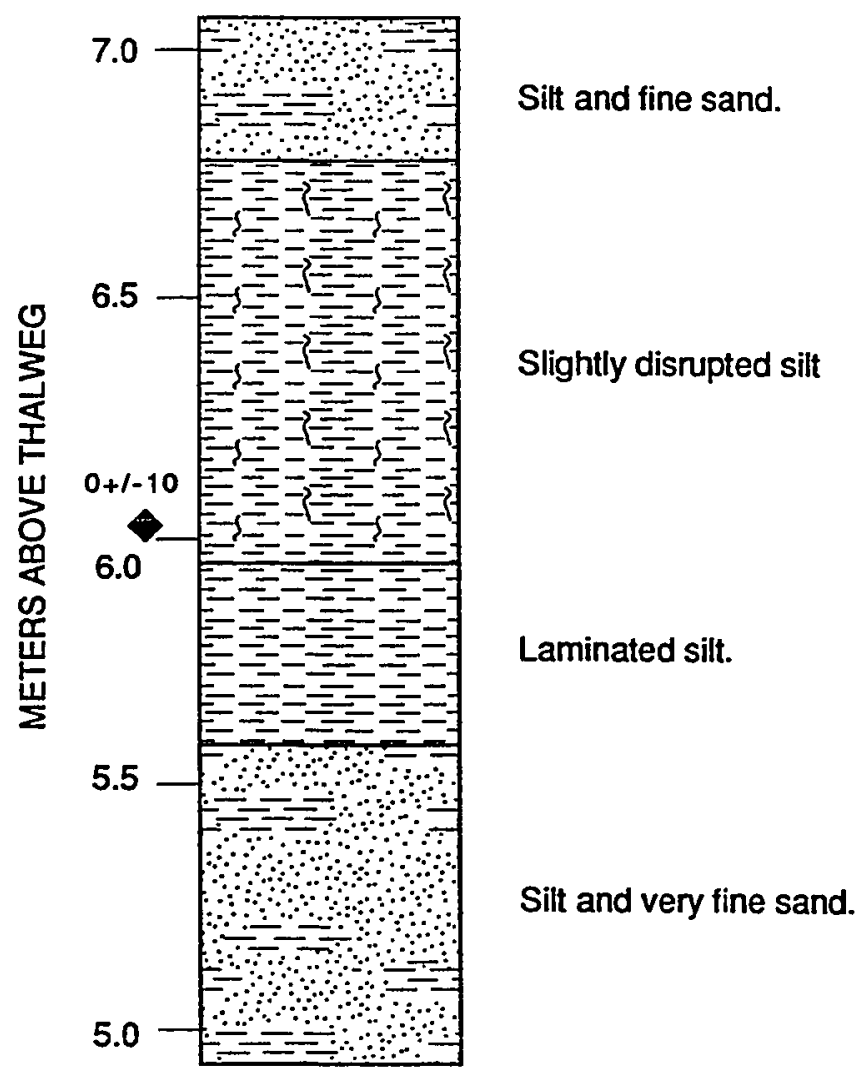




\section{Section 21}

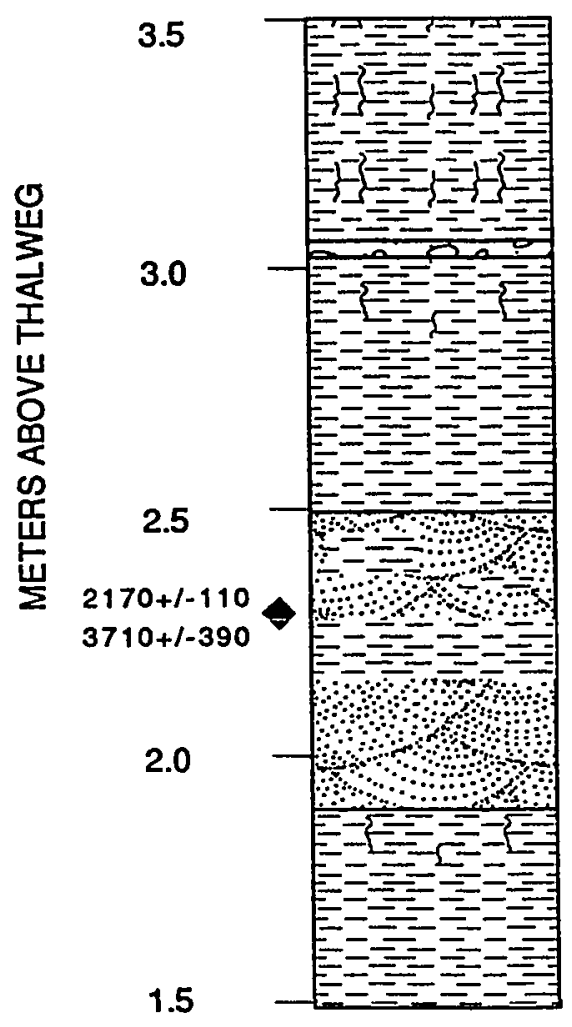

Silt. Mostly laminated with some bioturbation. Small red zone with some charcoal at top.

Medium sand.

Bioturbated silt at top. Laminated silt at bottom with some charcoal.

Cross bedded very fine sand with mud clasts in lower $30 \mathrm{cms}$. Interbedded silt layer. Cross bedded sand at bottom.

Silt with some bioturbation at top. 


\section{Section 21}

(continued from previous page)

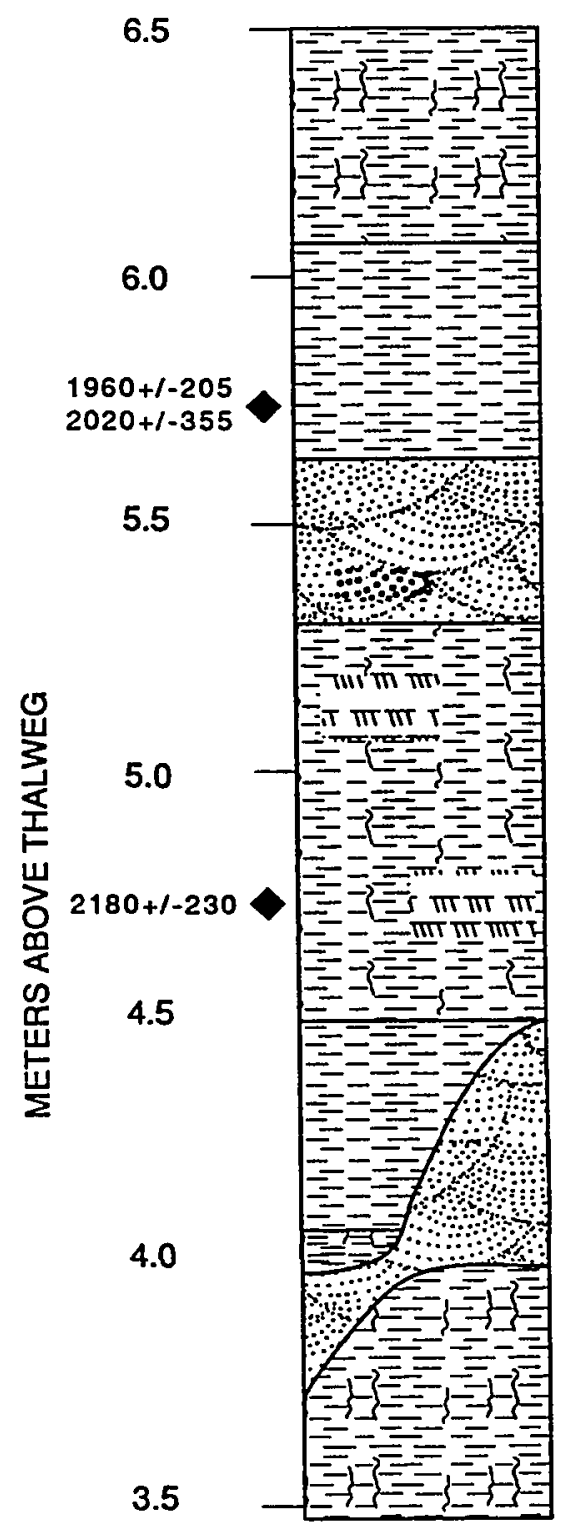

Mostly unlaminated, bioturbated silt.

Well laminated silt wilt minute red zone and charcoal.

Very fine sand with some 1-2 $\mathrm{mm}$ sized grains. Cross bedded.

Laminated and cross laminated silt. Slightly disturbed. Red zone with charcoal.

Medium to fine sand. Cross bedded with silt partings. Some absestos.

Slightly disturbed silt. Some laminations. 
113

\section{Section 21}

(continued from previous page)

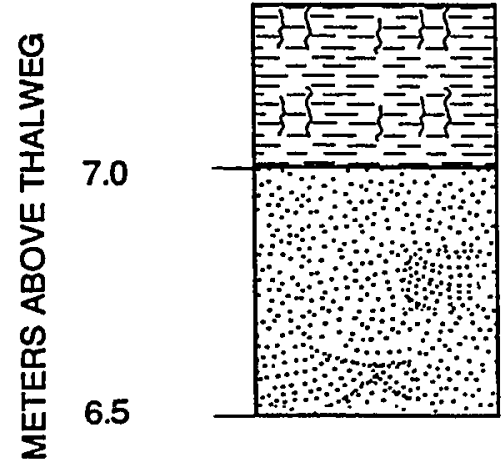

Plowed bioturbated top soil (silty sand).

Very fine sand with some cross bedding. Asbestos present. 


\section{Section 22}

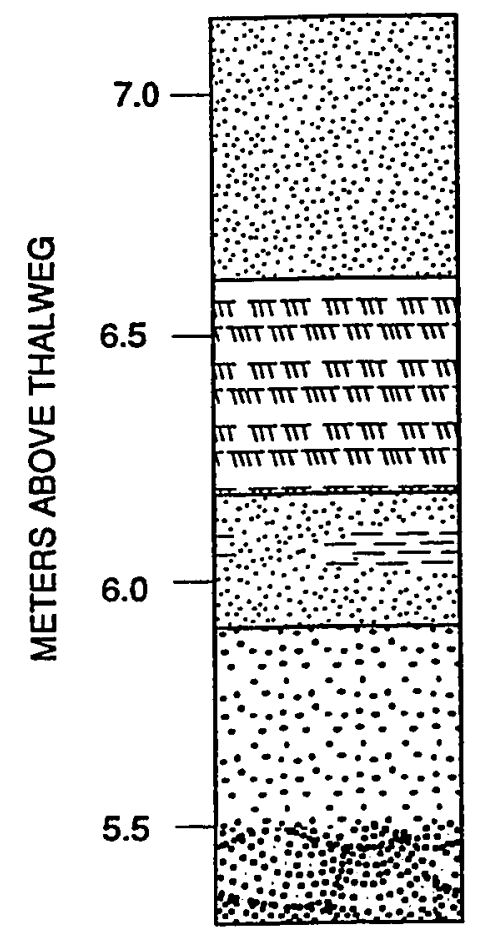

Bioturbated very porous soil. Some

rip-up clasts. Fine to very fine sand.

Finely laminated and cross laminated sitt and sandy silt.

Porous silty sand. Some cross laminated and laminated. Few rip-up clasts. Many root marks.

Medium sand. Cross bedded at base. Few rip-up clasts. 


\section{Section 22}

(continued from previous page)

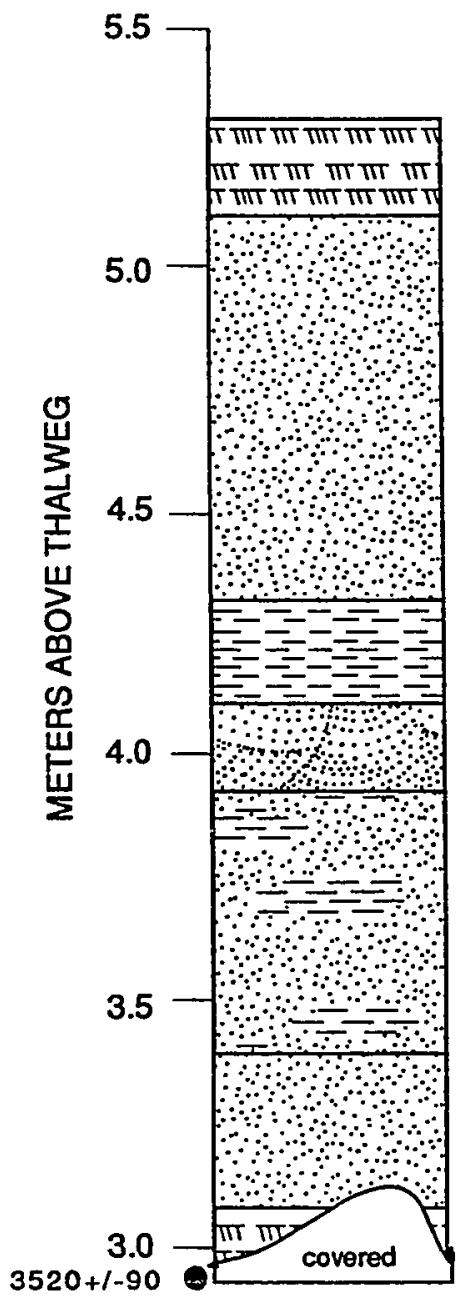

Cross laminated silt at base. Porous sandy silt at top with rip-up clasts.

Very fine sand. Pores, root marks, bioturbation, rip-up clasts common. No bedding.

Finely laminated silt. Some cross laminated silt. Mudcracks common.

Cross bedded very fine sand.

Very fine sand and silt. Porous with no bedding. Some beds of laminated silt and medium sand.

Fine sand with 2 interbeds of cross laminated silt. Some cross beds. Many rip-up clasts.

Cross laminated silt. 


\section{Section 26}

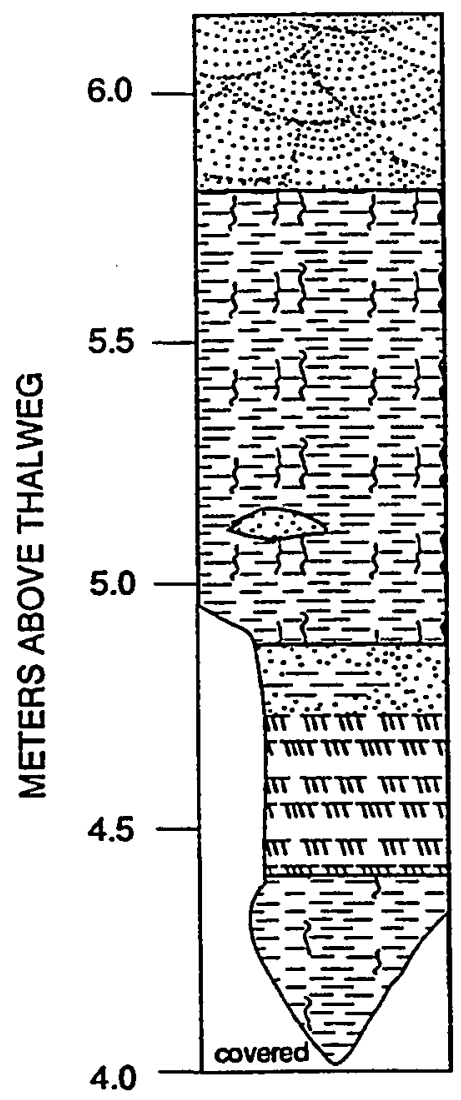

Steeply cross bedded very fine sand. Abundant aspestos and minor charcoal in upper beds.

Broken apart, cracked, porous silt with some lamination. Root marks, filled burrows, and carbonate increases upsection. Large, dispersed charcoal. $5 \mathrm{~cm}$ thick red zone at 5.6 meters. Thin sand lens at 5.1 meters.

Steeply cross laminated silt. some very fine sand at top interbedded with sitt. Some carbonated in upper layers.

Finely laminated silt. Some cross lamination. Minor carbonate content. Some mudcracks and raindrop imprints. 


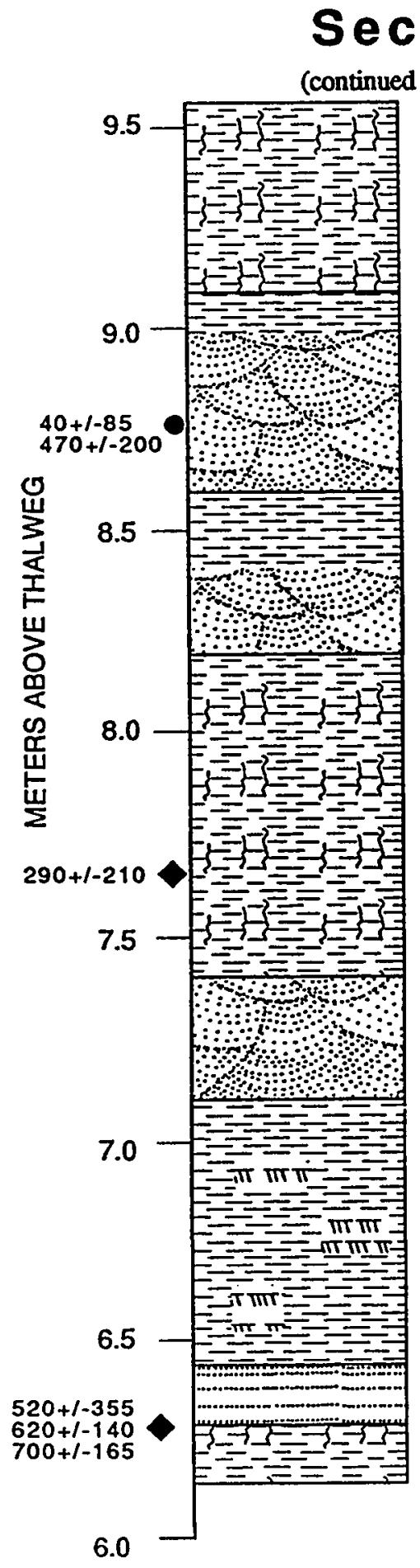

Plowed top soil. Bioturbated, roots, pores.

Medium to very fine sand. Strongly cross bedded in lower part with asbestos and charcoal. Well laminated sitt at top.

Laminated silt at top. Cross bedded sand at bottom. Very thin burn zone.

Mostly silt with some sandy silt. Mostly laminated but with many pores and root marks. One small burn zone. Increasing carbonate content upsection.

Fine to very fine sand. Steeply cross bedded.

Mostly silt with some very fine sand. Locally cross bedded. Locally contains carbonate, root marks, and pores. Small blackish burn zone.

Well bedded fine sand.

Well laminated silt. Some pores and root marks. Lots of dispersed carbonate - increasing upsection. Bioturbation marks. Black burn zone at top. 


\section{Section 27}

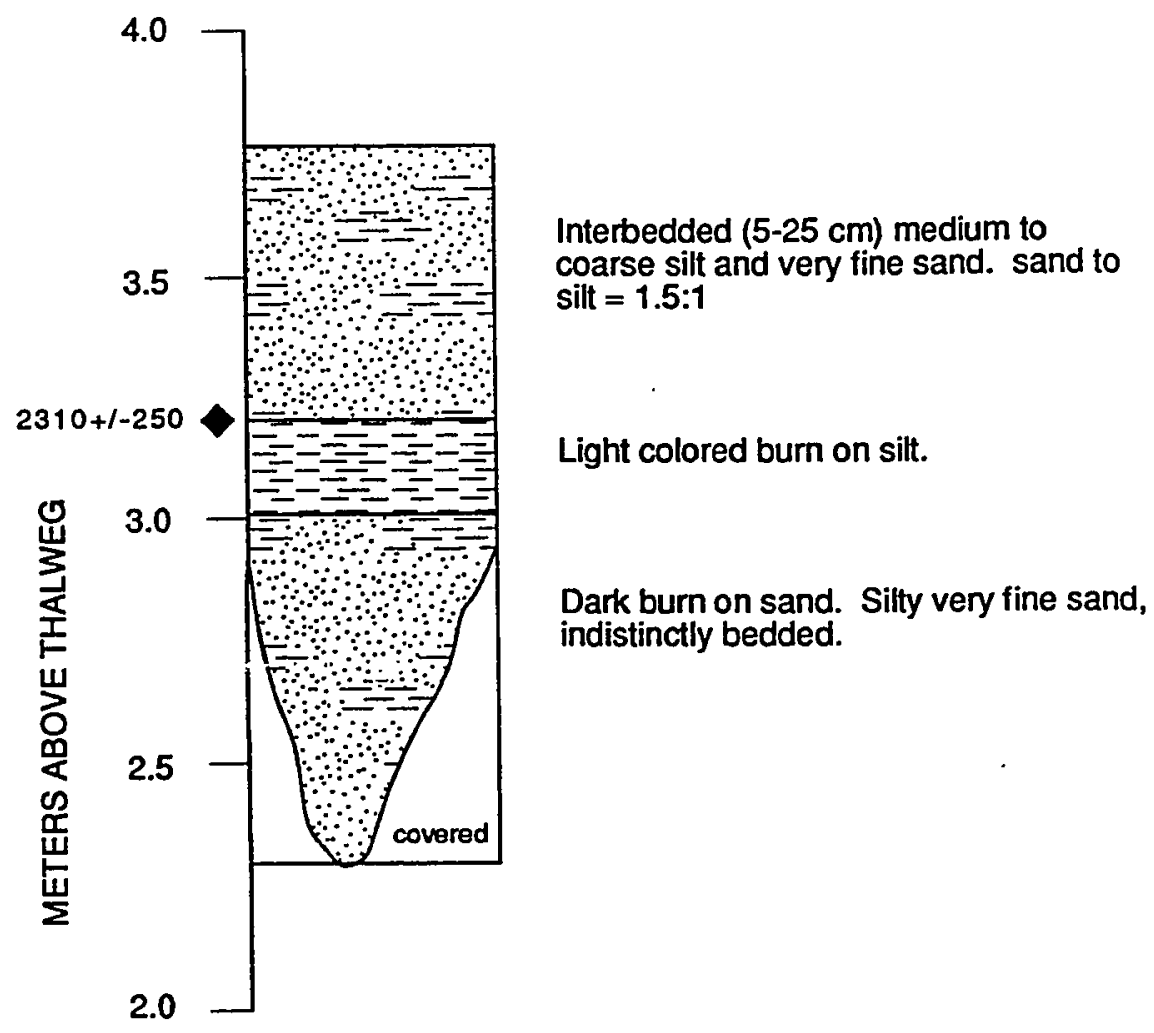




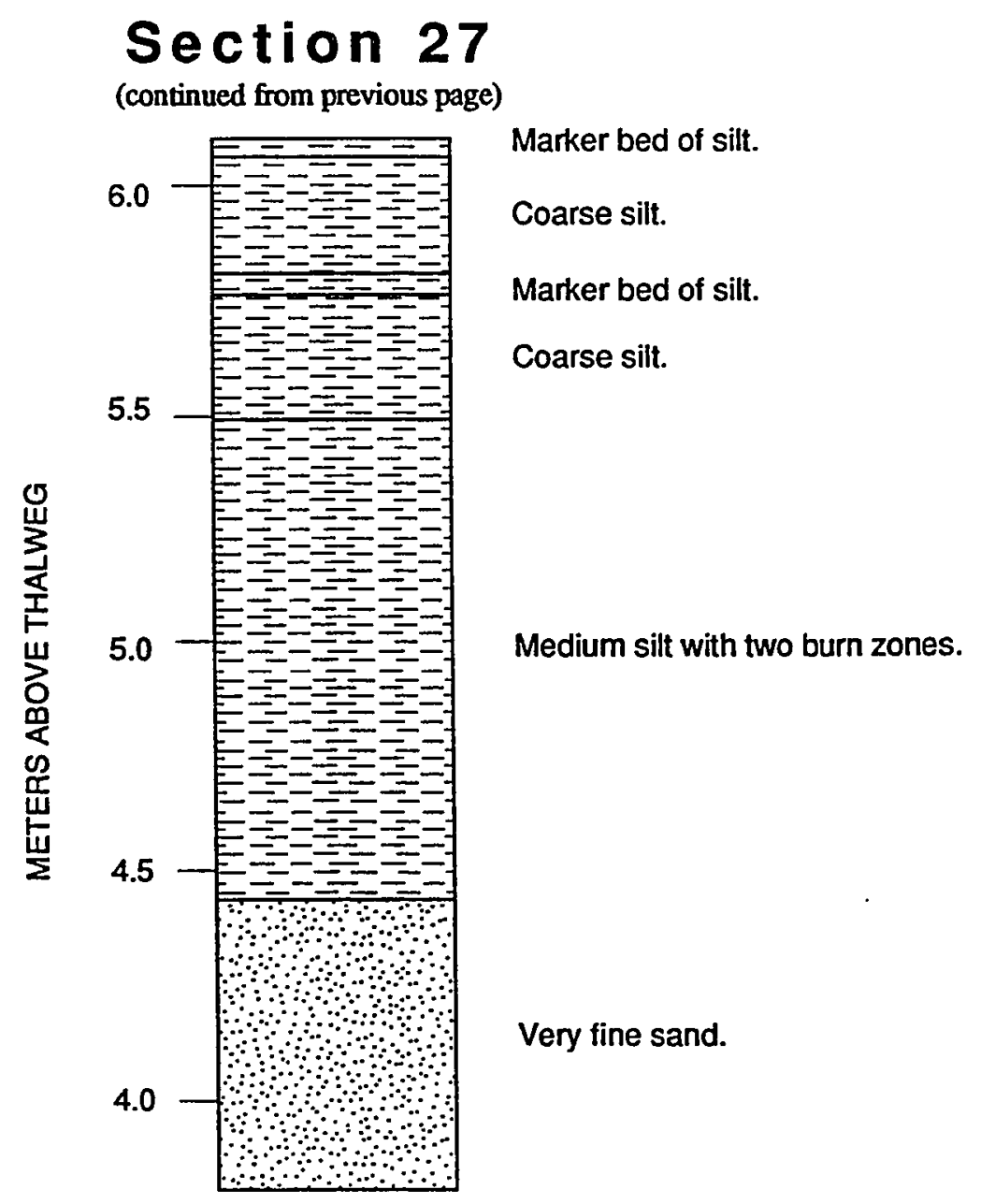




\section{Section 27}

(continued from previous page)

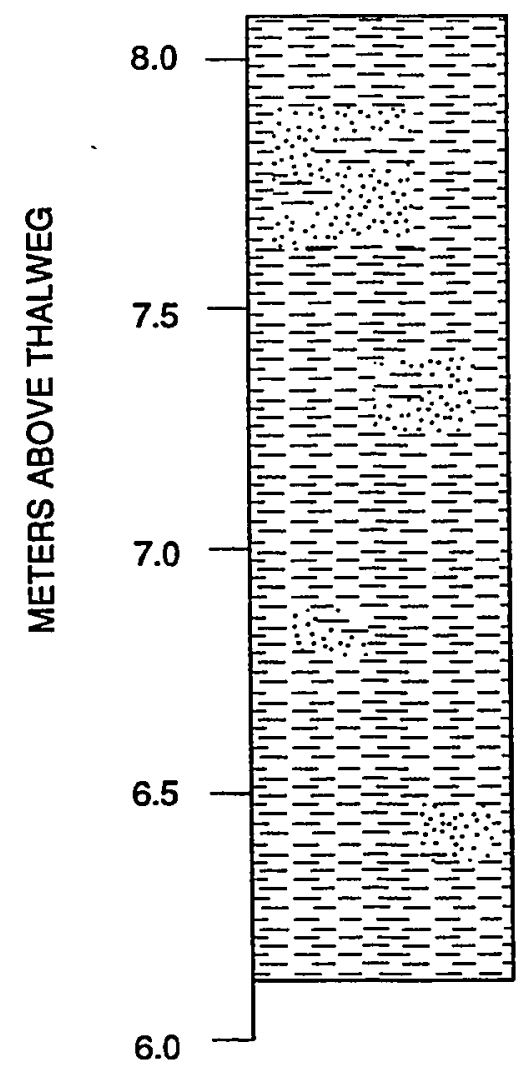

Mostly coarse silt.

Some sandy sitt.

One burn zone at 7.6 meters. 


\section{Section 86-3}

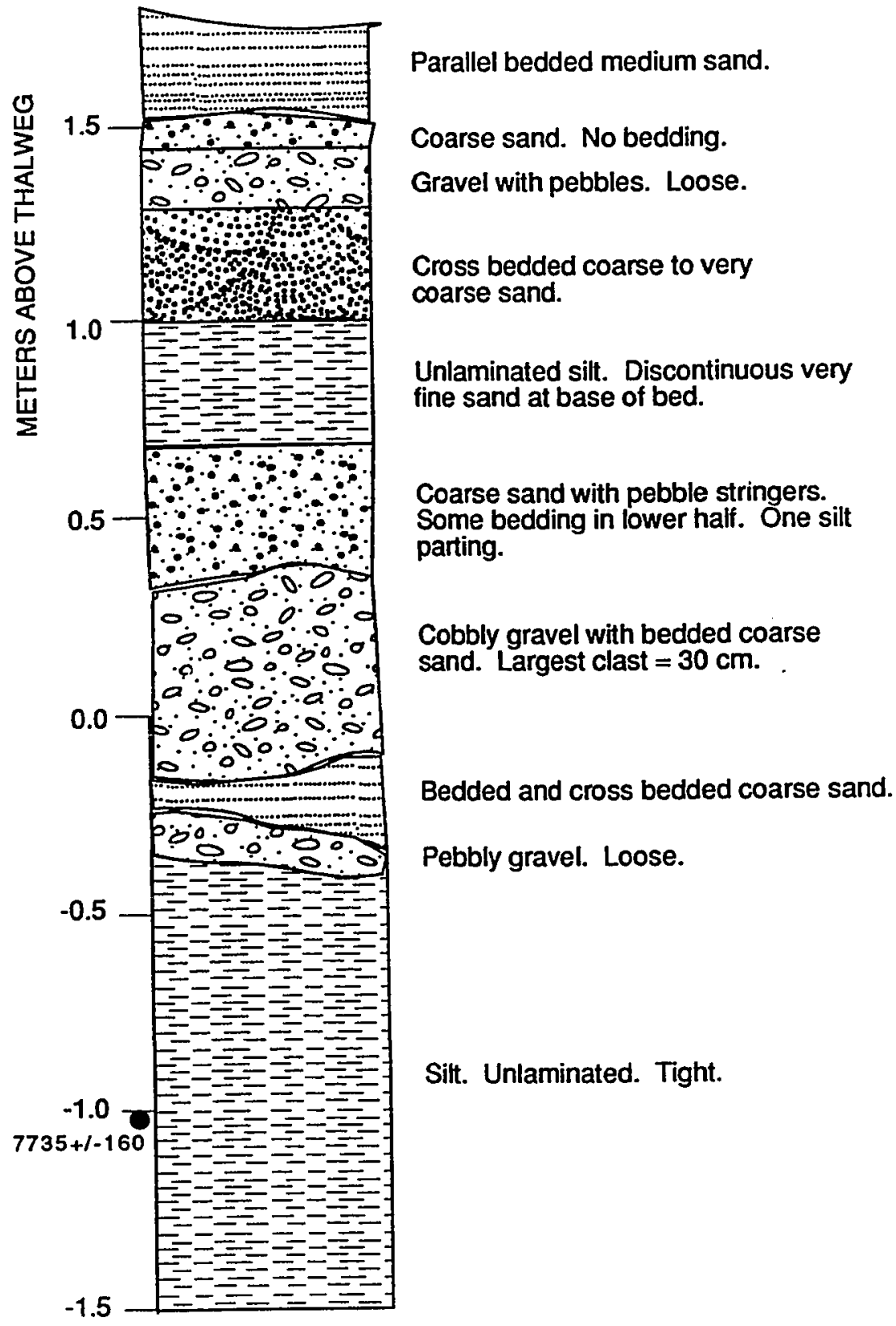




\section{Section 86-3}

(continued from previous page)

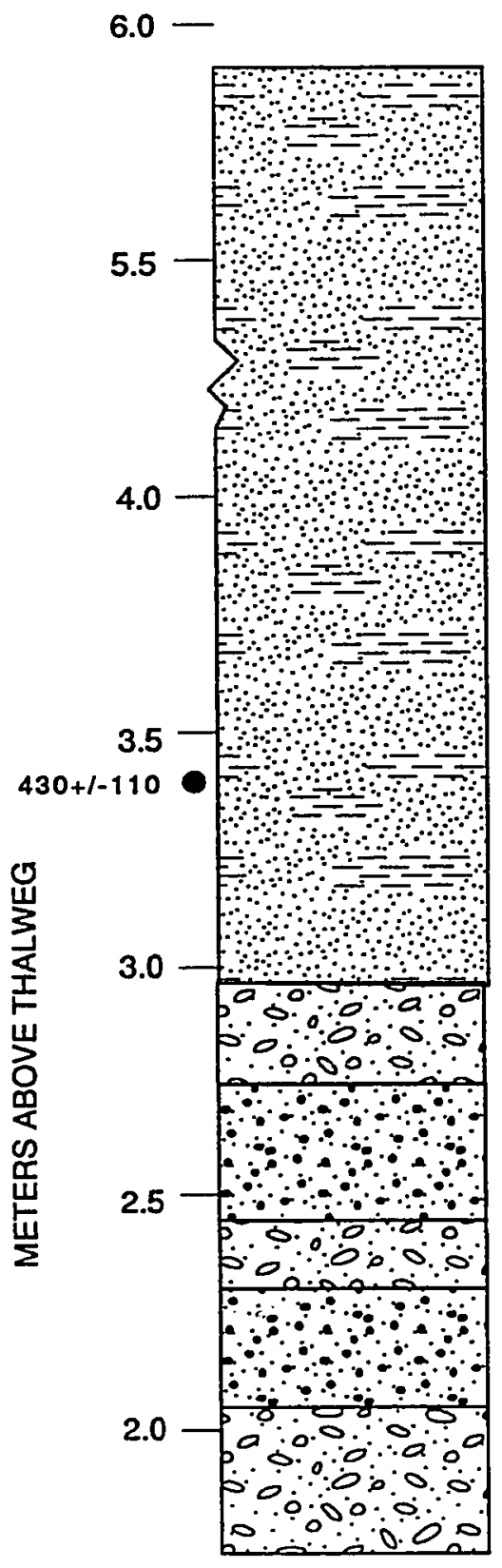

Fine sandy silt. No structures, no bedding. Some pebbles.

Pebbly gravel with coarse sand.

Coarse to very coarse sand with pebbles.

Gravel. No bedding. Fine matrix.

Coarse sand with pebbles.

Bouldery gravel with fine matrix. No bedding. 


\section{Section 86-4}

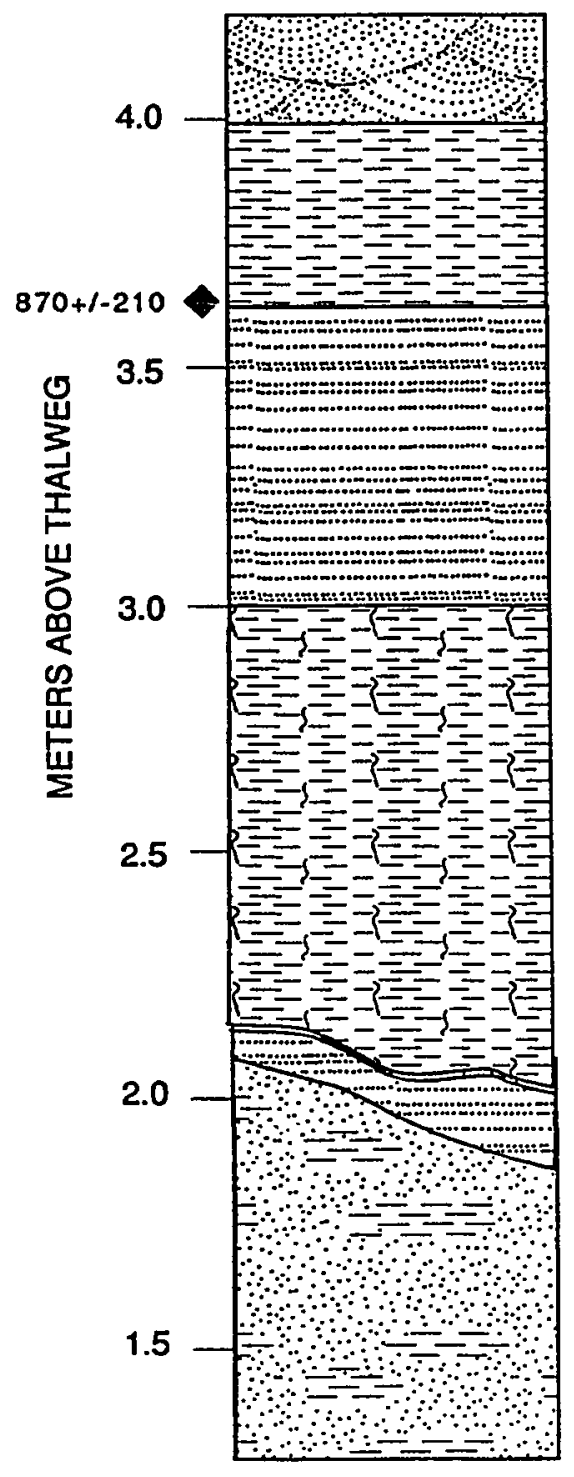

Cross bedded sand.

Silt.

Well bedded sand. Some cross beds.

Silt with laminations mostly

disnupted. Many silt clasts.

One discontinuous bed of medium sand.

Well bedded coarse sand.

Sandy silt. Laminations mostly disrupted. Silt clasts common. 


\section{Section 86-4}

(continued from previous page)

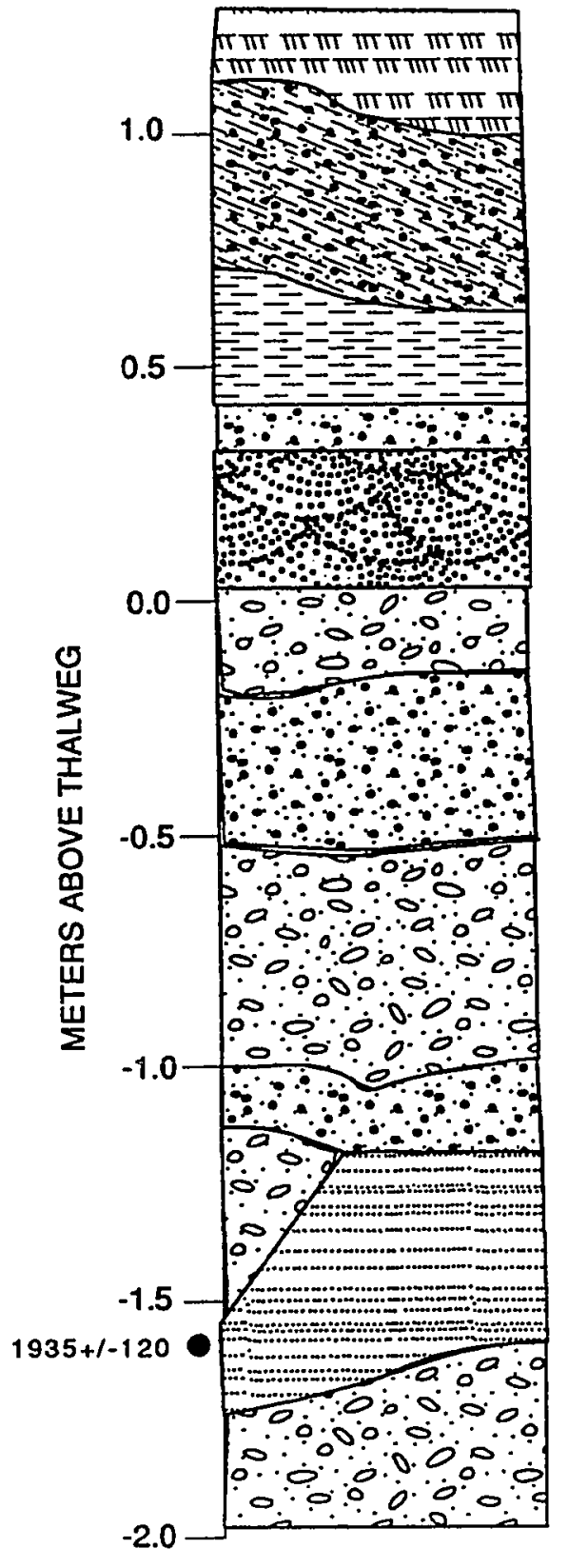

Leftward climbing ripples with mud drapes. Sitt with fine sand.

Medium to coarse sand. Planar cross bedded.

Coarse to fine silt. Somewhat laminated.

Well bedded coarse sand.

Well bedded and cross bedded medium sand.

Well bedded and cross bedded pebbly sand and gravel.

Poorly bedded coarse gravel to pebbly sand. Some well bedded and cross bedded pebbly sand.

Poorly bedded upward fining coarse gravel to pebbly sand.

Poorly bedded medium to coarse sand.

Coarse sand to gravelly sand. Steeply dipping cross beds.

Well bedded coarse sand.

Upward coarsening gravelly sand. 


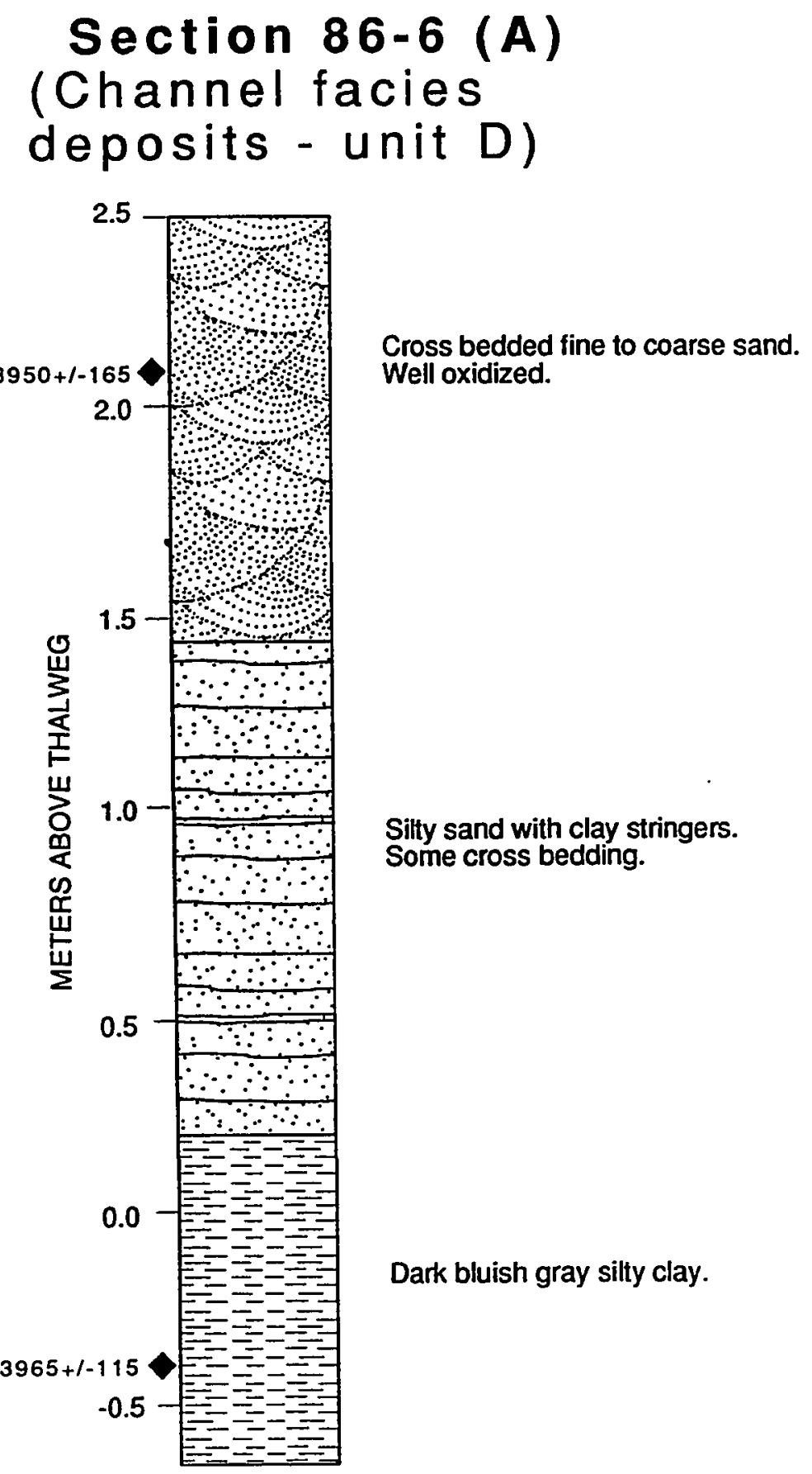




\section{Section 86-6 (A) \\ (Channel facies deposits - unit D)}

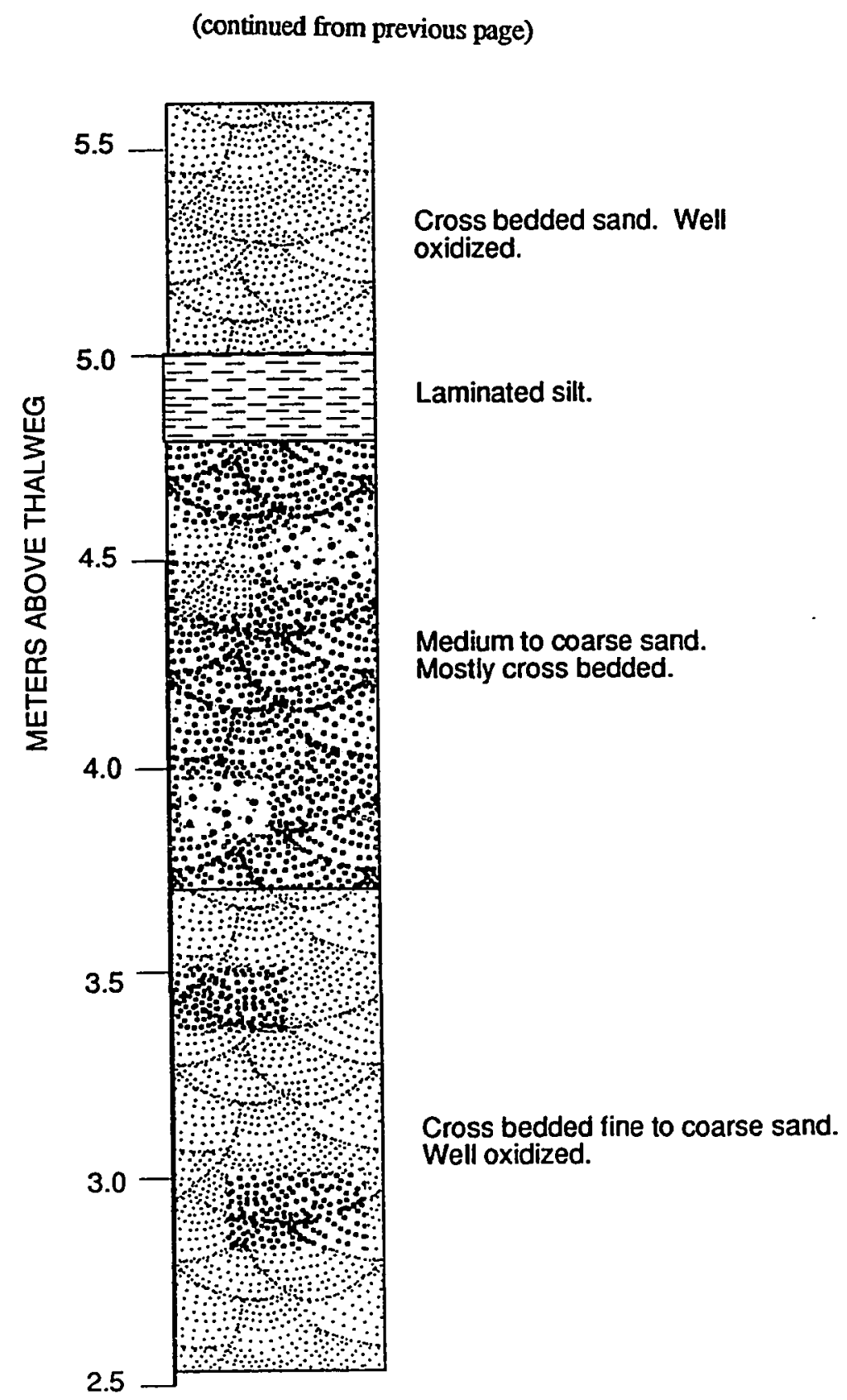




\section{Section 86-4}

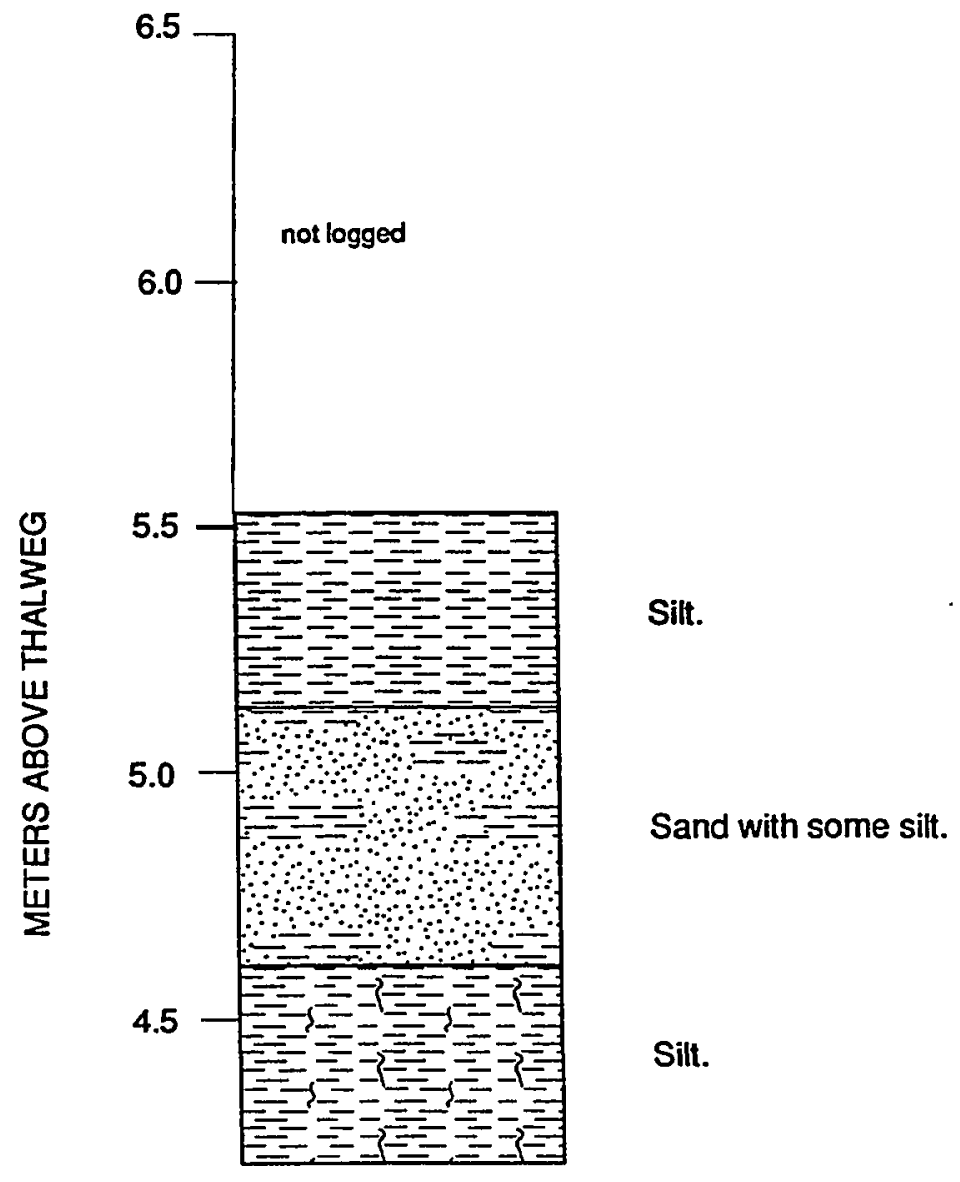




\section{Section 86-4}

(continued from previous page)

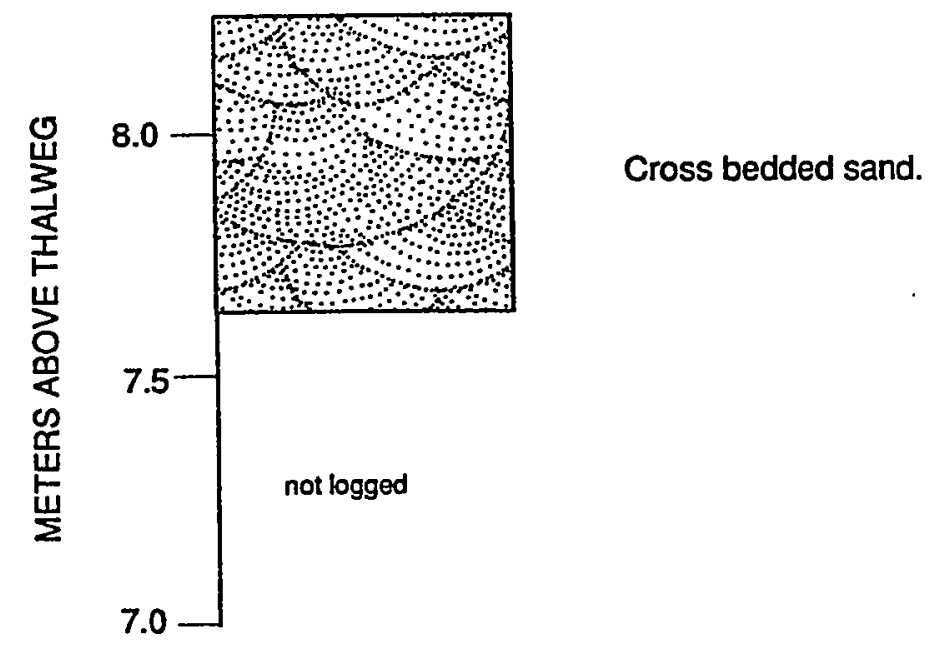




\section{Section 86-6 (A) \\ (Channel facies deposits - unit D)}

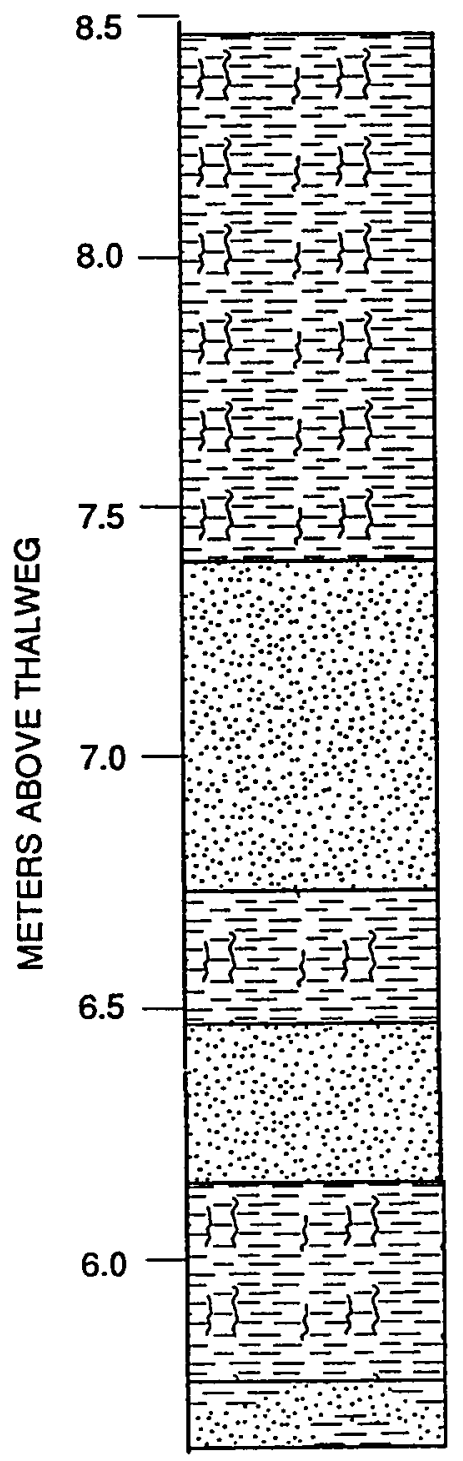

Dark, bioturbated silt. Laminations mostly disrupted.

Fine sand.

Bioturbated silt.

Fine sand.

Bioturbated silt.

Silty fine sand. 


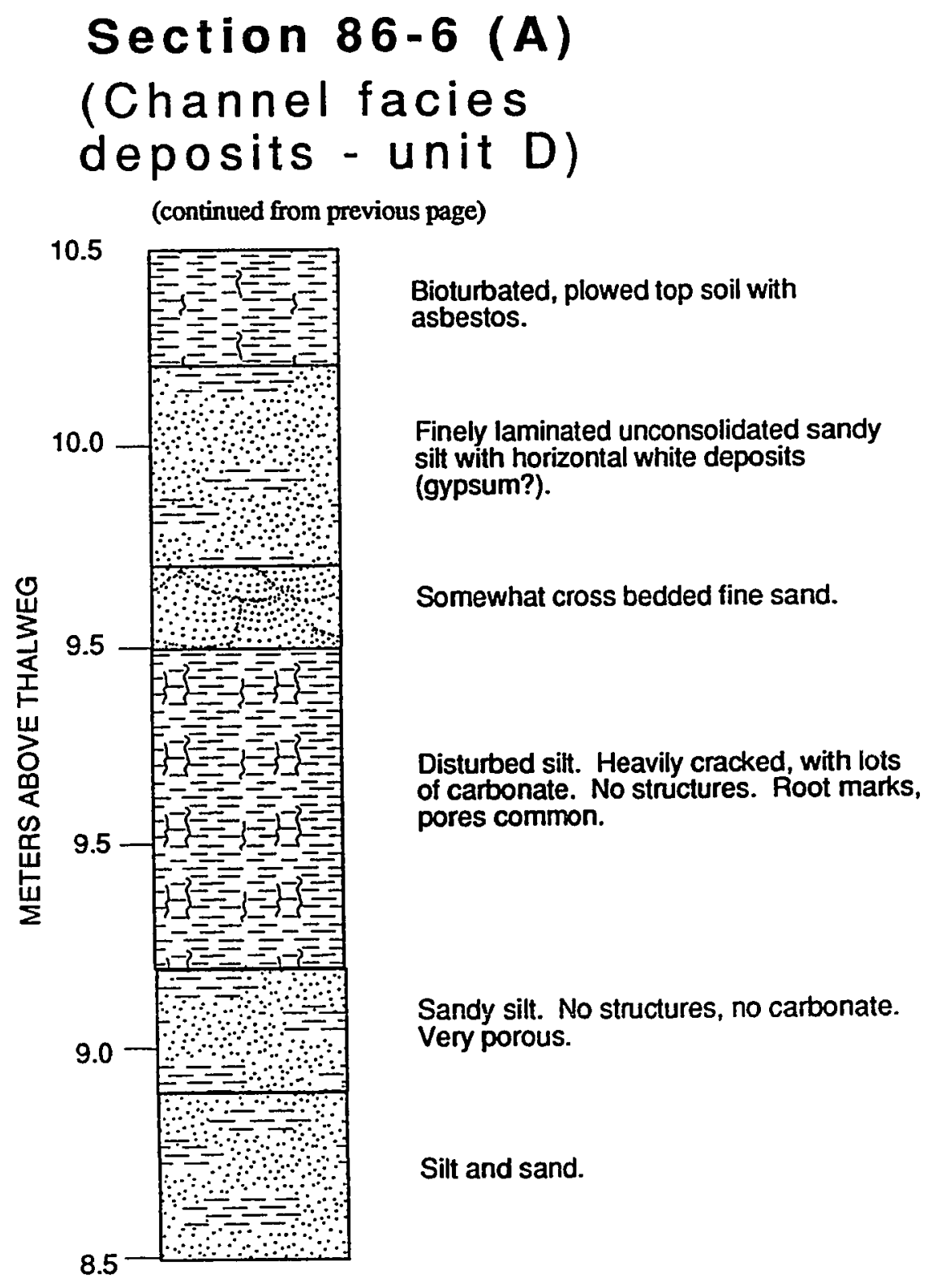




\section{Section 86-6 (B) \\ (levee deposits - unit C)}

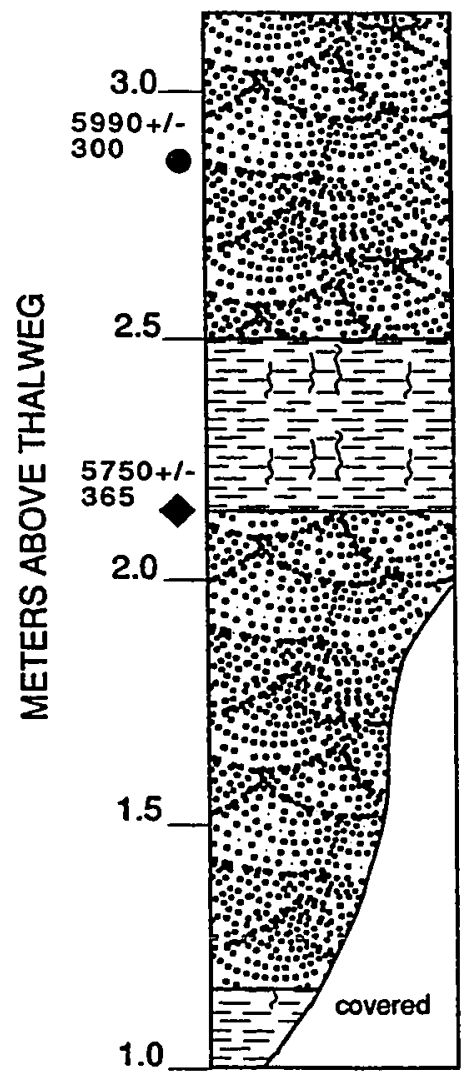

Medium to fine sand. Cross bedded throughout (large ripples) with coarse sand in troughs. Asbestos and pores common. Two discontinuous silt layers. Some root marks. Oxidation and mottling common.

Unlaminated silt. Mottling, root marks with oxidation halos, and vertical cracks common. Burn zone at base (baked sand).

Medium to fine sand. Cross bedding and cross lamination common. Seven to ten discontinuous wavy silt layers ( $\max$. thickness $=3 \mathrm{~cm}$ ). Silt rip-ups dispersed throughout. Many root marks with oxidation halos.

Unlaminated silt. Vertical cracks, carbonates, root marks with oxidation halos common. Carbonates $=10 \mathrm{YR} 8 / 1$ 


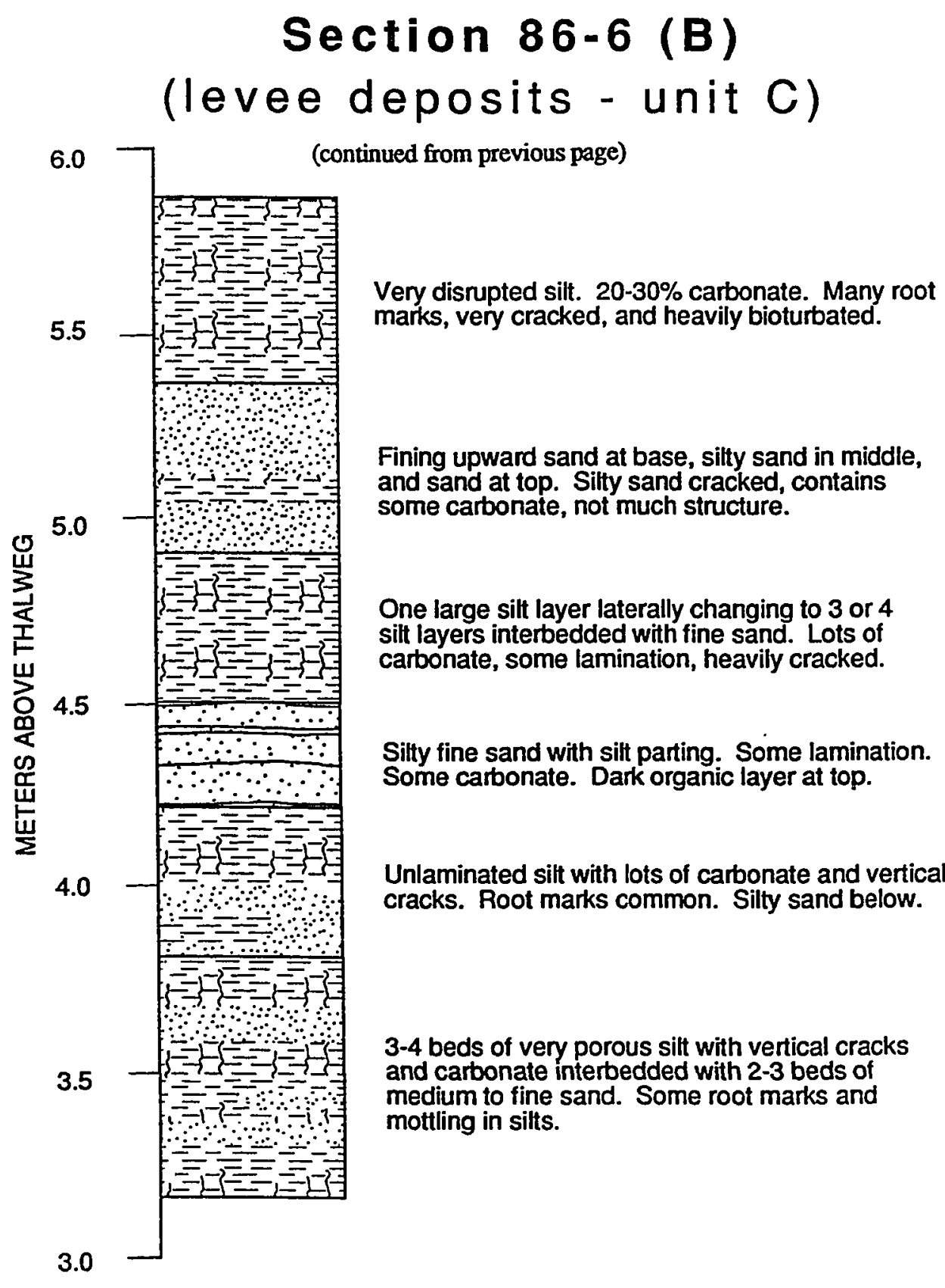




\section{Section 86-6 (B) \\ (levee deposits - unit C)}

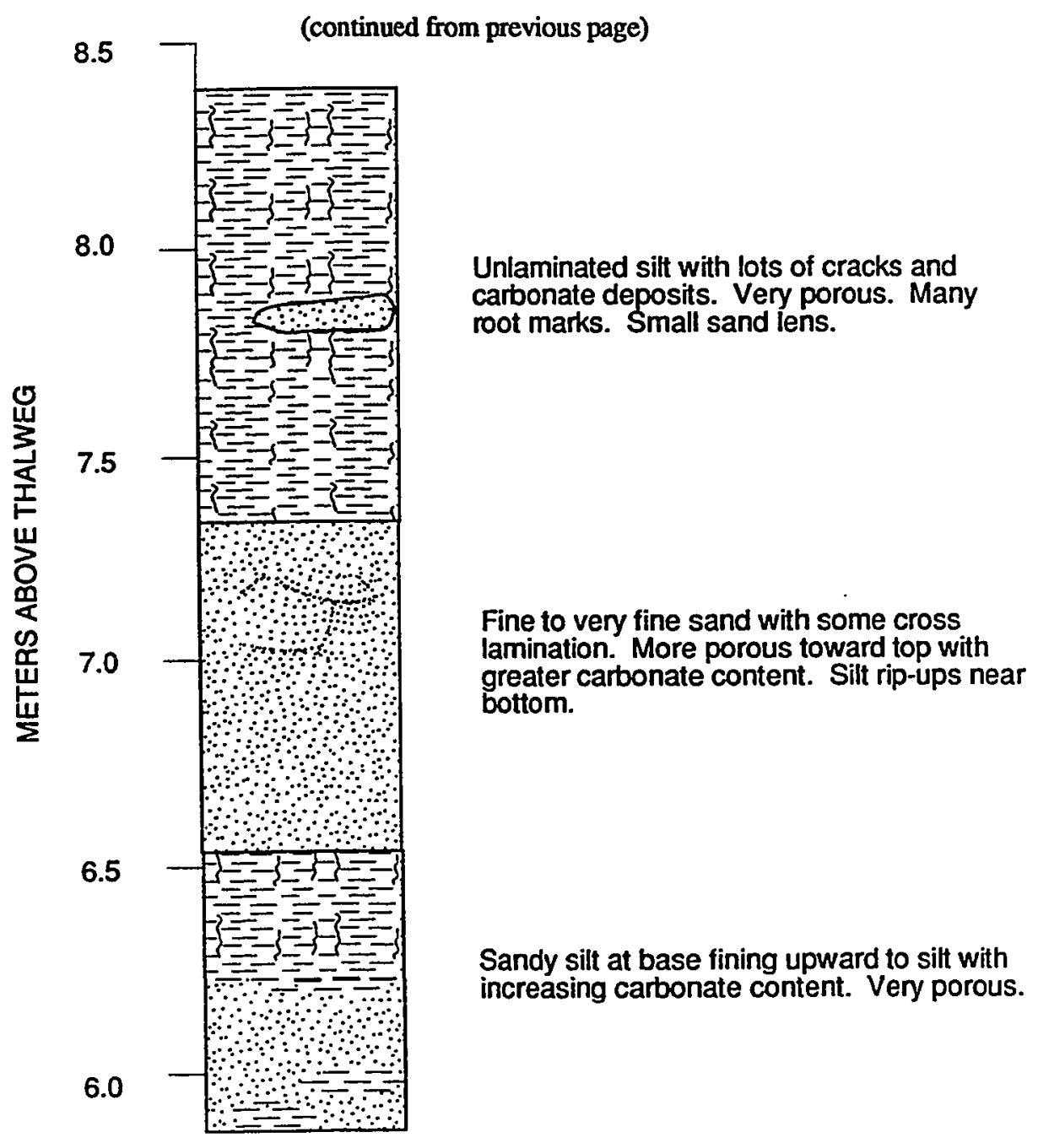




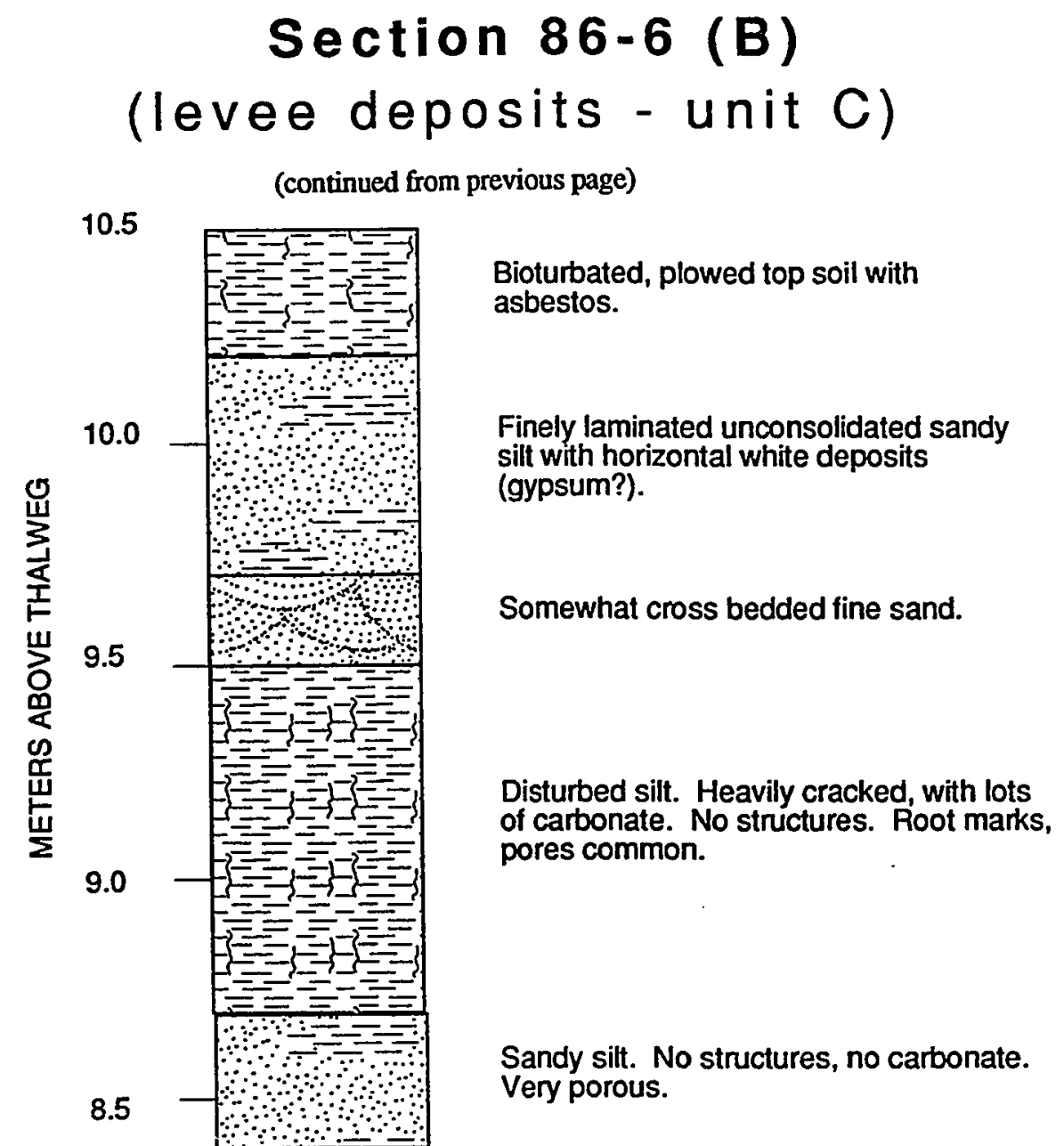




\section{Section 86-6 (C) \\ (Channel facies deposits - unit D)}

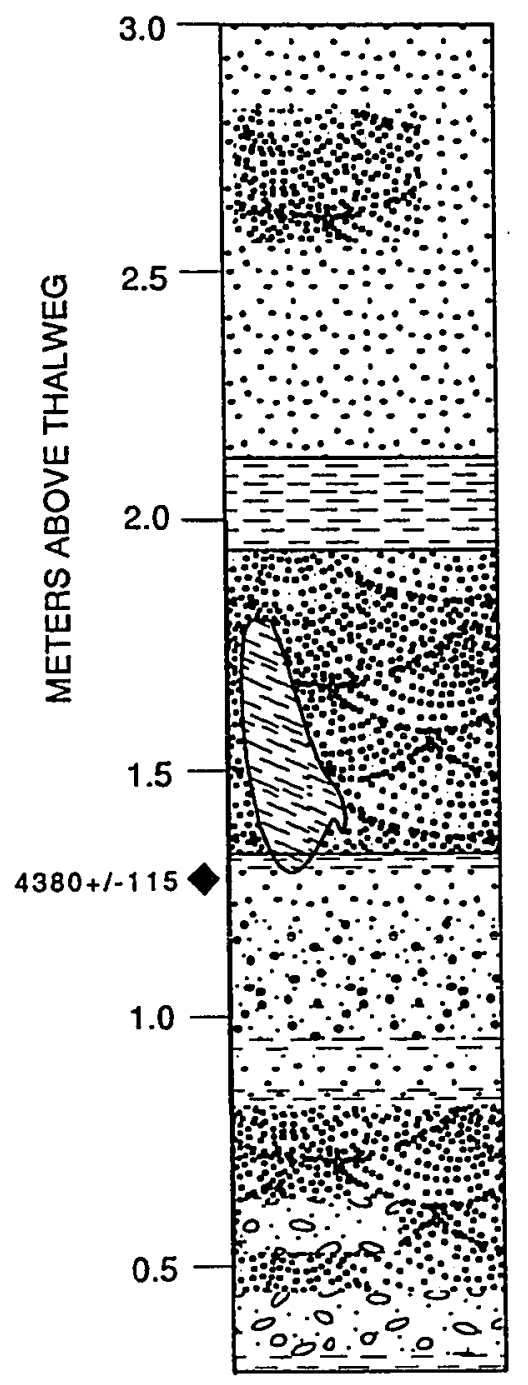

Cross bedded medium to coarse sand. Many root casts. Red-orange oxidation common.

Laminated silt.

Dark medium sand. Some cross beds, silt stringers. Many root casts.

Talus block from section 86-6D.

Medium to coarse sand somewhat cross bedded interbedded with 4 continuous silt layers. Some pebbles. 


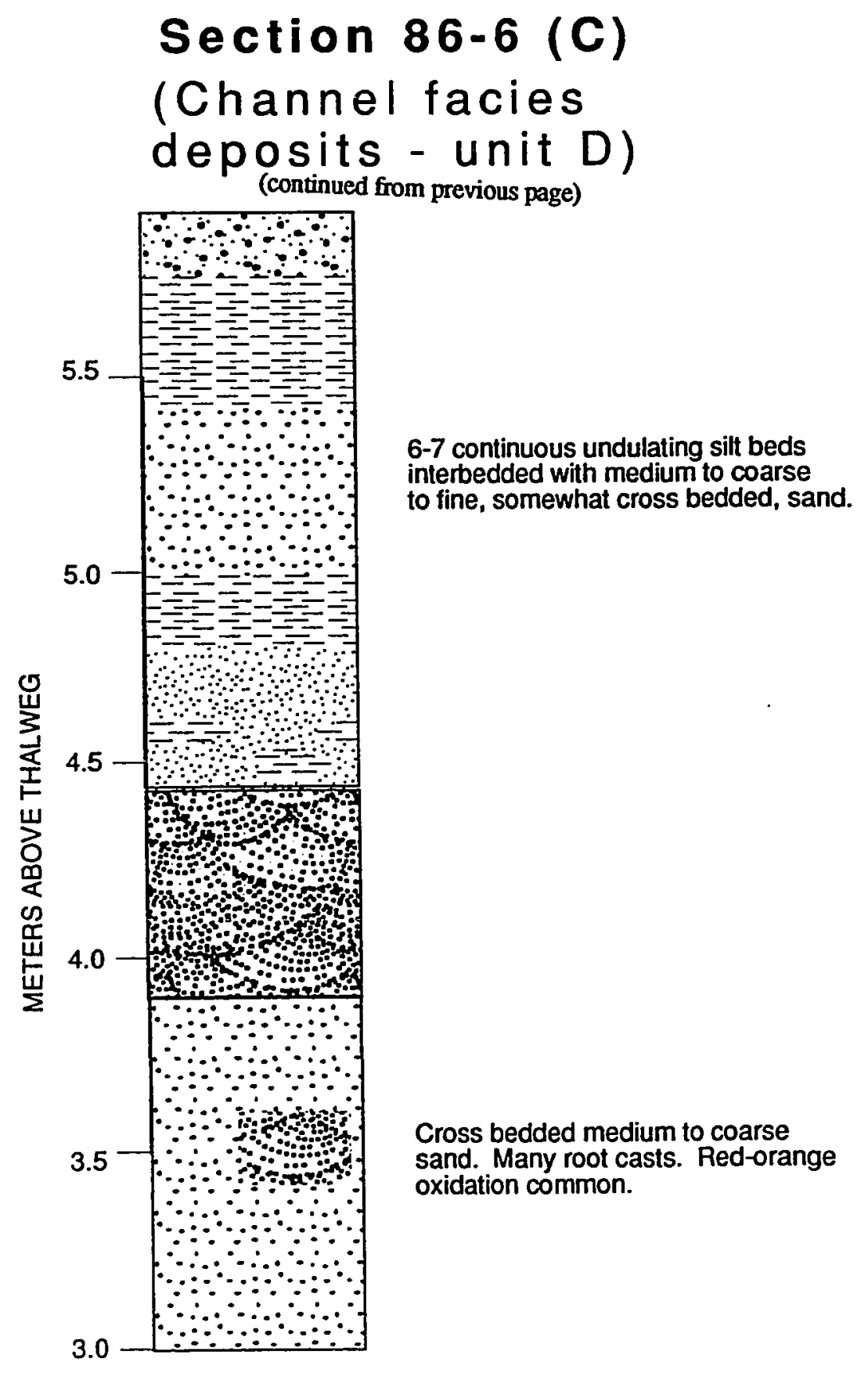




\section{Section 86-6 (C) (Channel facies deposits - unit D)} (continued from previous page)

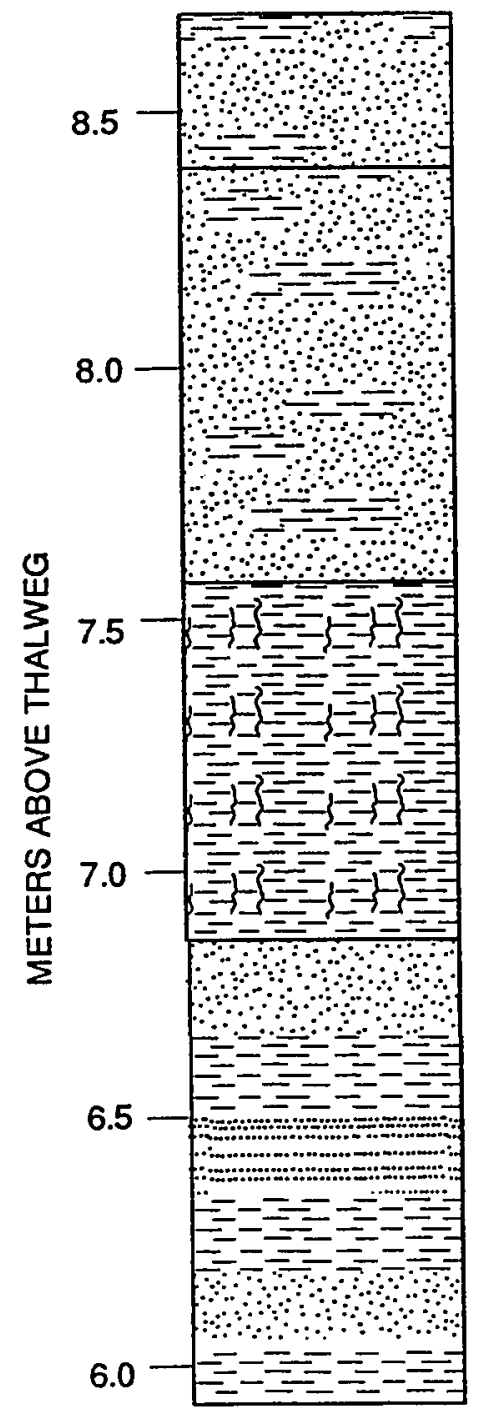

Sandy silt. No structures, no carbonate. Very porous.

Sitt and sand.

Dark, bioturbated silt. Laminations mostly disnupted.

6-7 continuous undulating silt beds interbedded with medium to coarse to fine, somewhat cross bedded, sand. 


\section{Section 86-6 (C) (Channel facies deposits - unit D)}

(continued from previous page)

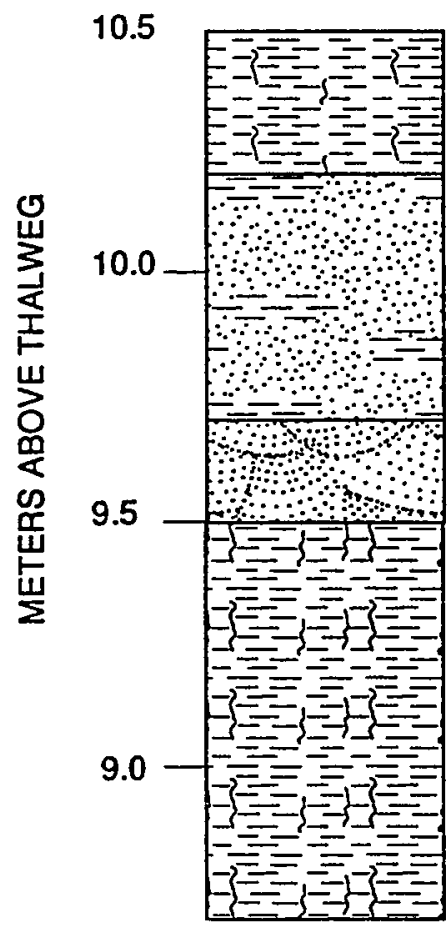

Bioturbated, plowed top soil with asbestos.

Finely laminated unconsolidated sandy silt with horizontal white deposits (gypsum?).

Somewhat cross bedded fine sand.

Disturbed silt. Heavily cracked, with lots of carbonate. No structures. Root marks, pores common. 


\section{Section 86-6 (D) (abandoned channel deposits - unit C)}

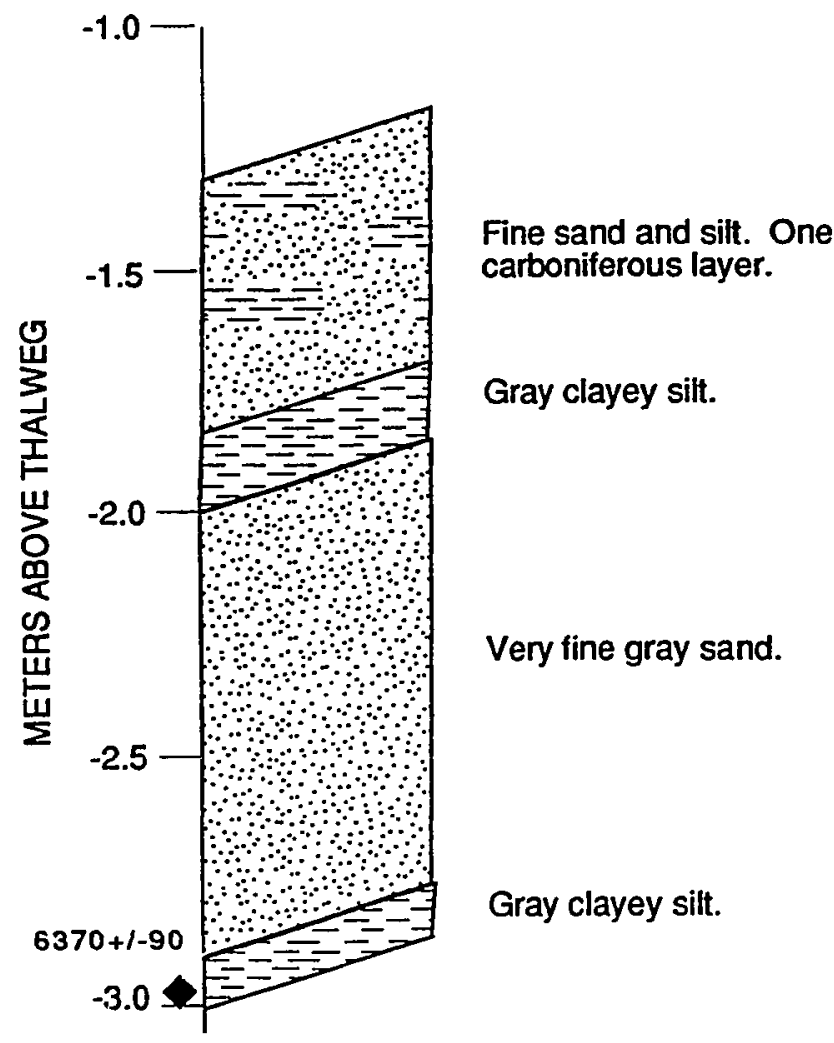




\section{Section 86-6 (D) (abandoned channel deposits - unit C)}

(continued from previous page)

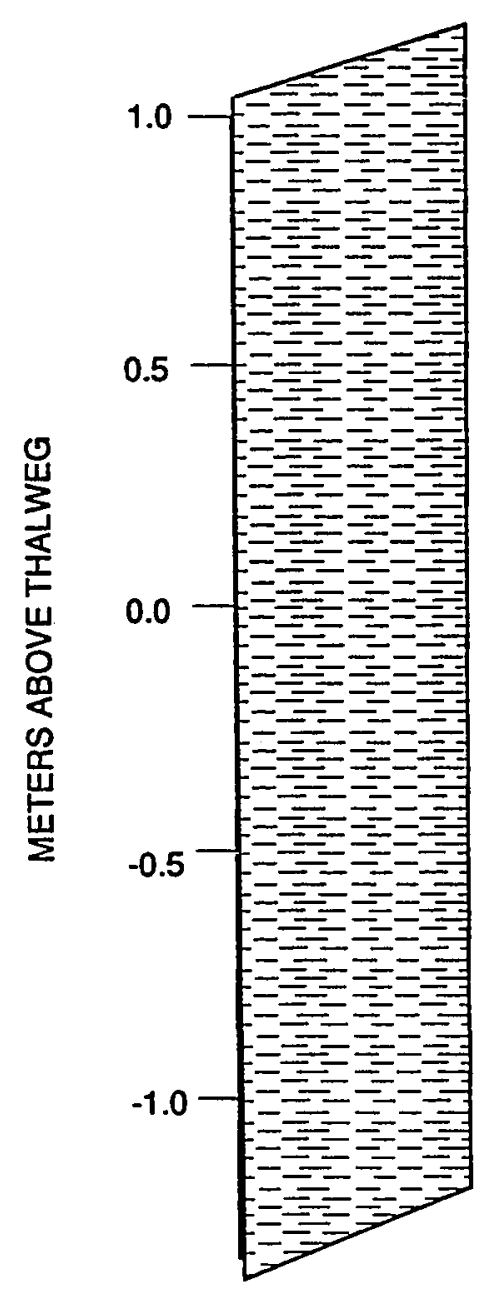

Fine silt and clay. 


\section{Section 86-6 (D) \\ (abandoned channel deposits - unit C)}

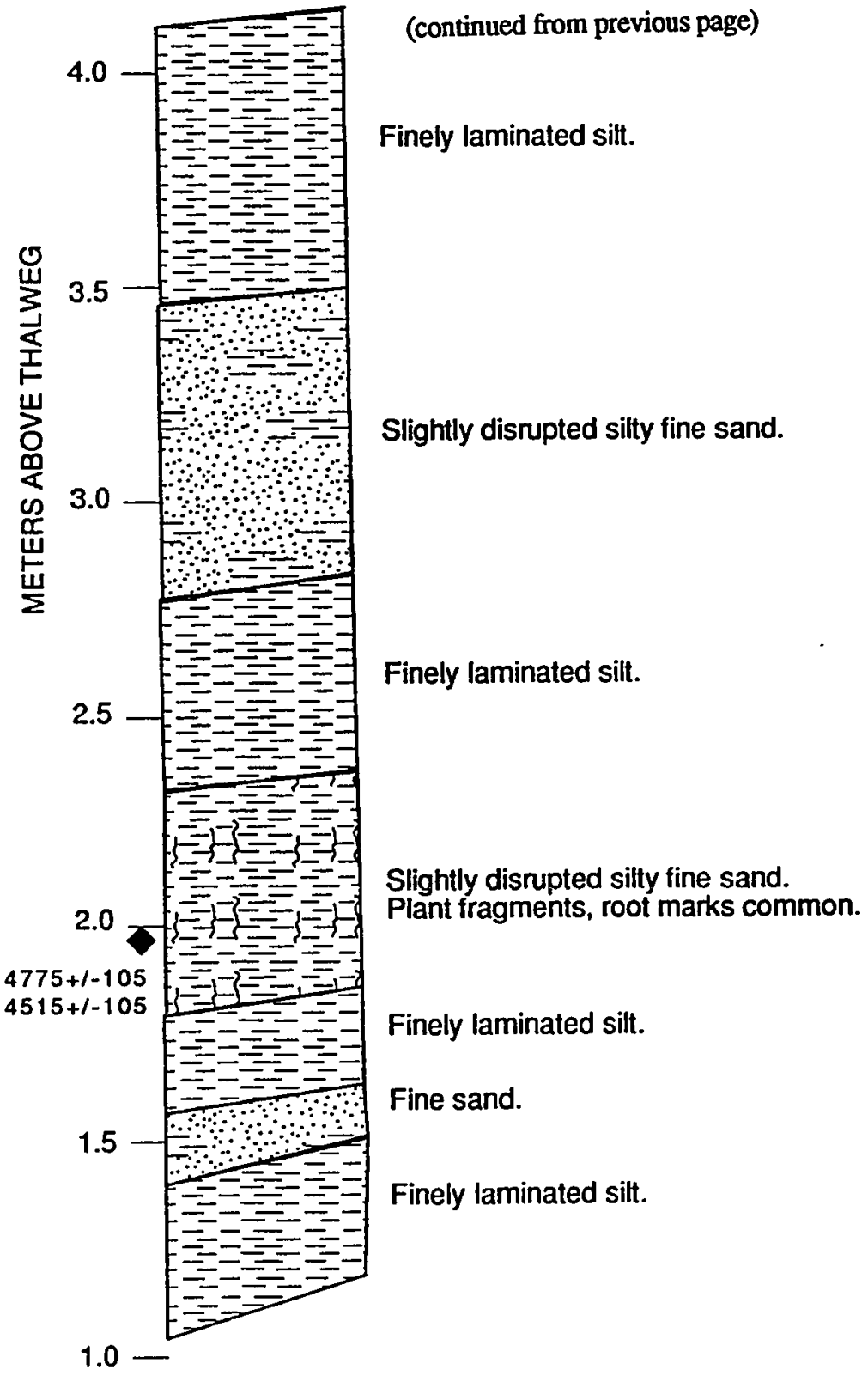




\section{Section 86-6 (D) \\ (abandoned channel deposits - unit C) \\ (continued from previous page)}

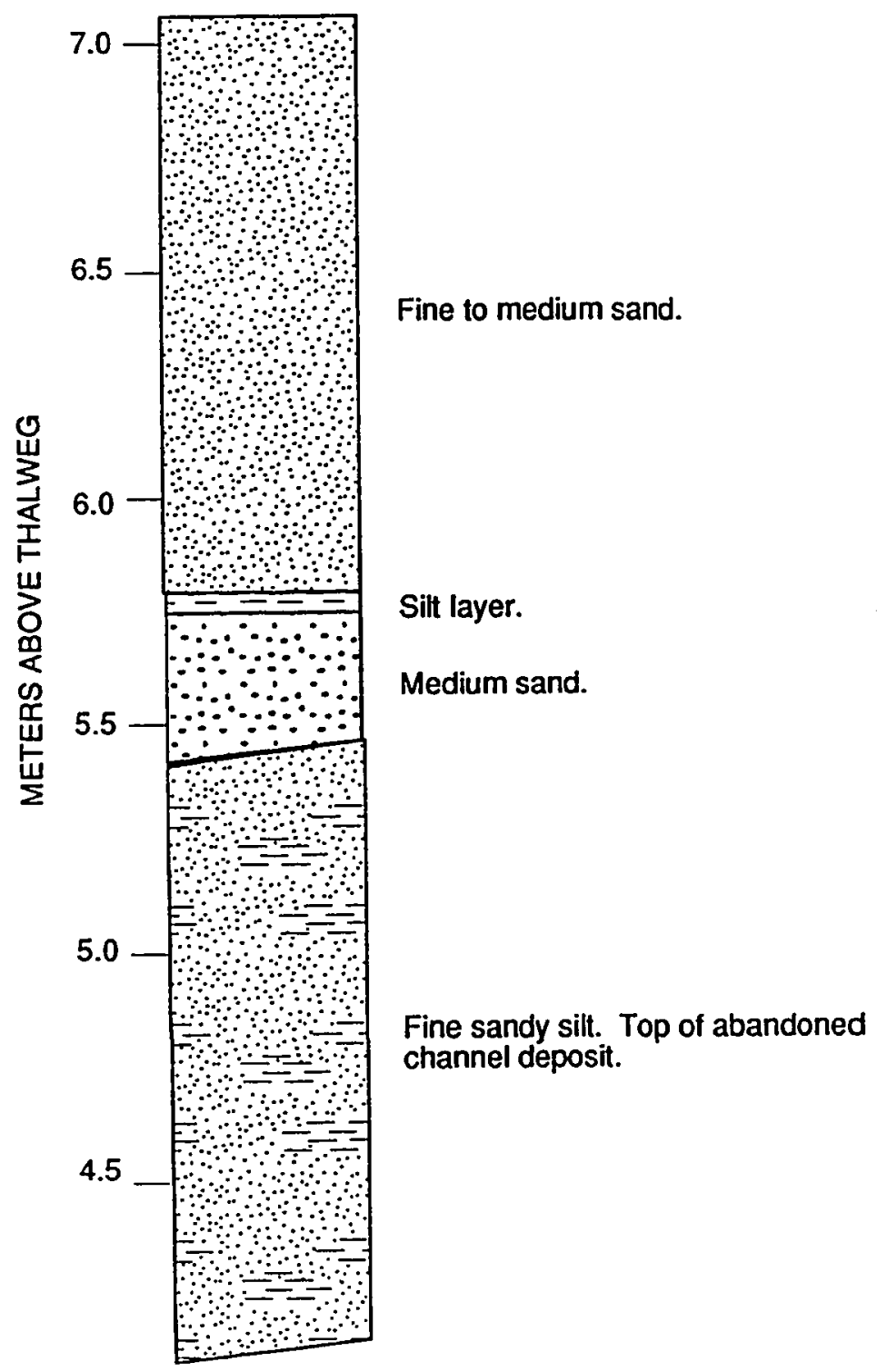




\section{Section 86-6 (D) \\ (abandoned channel deposits - unit C)}

(continued from previous page)

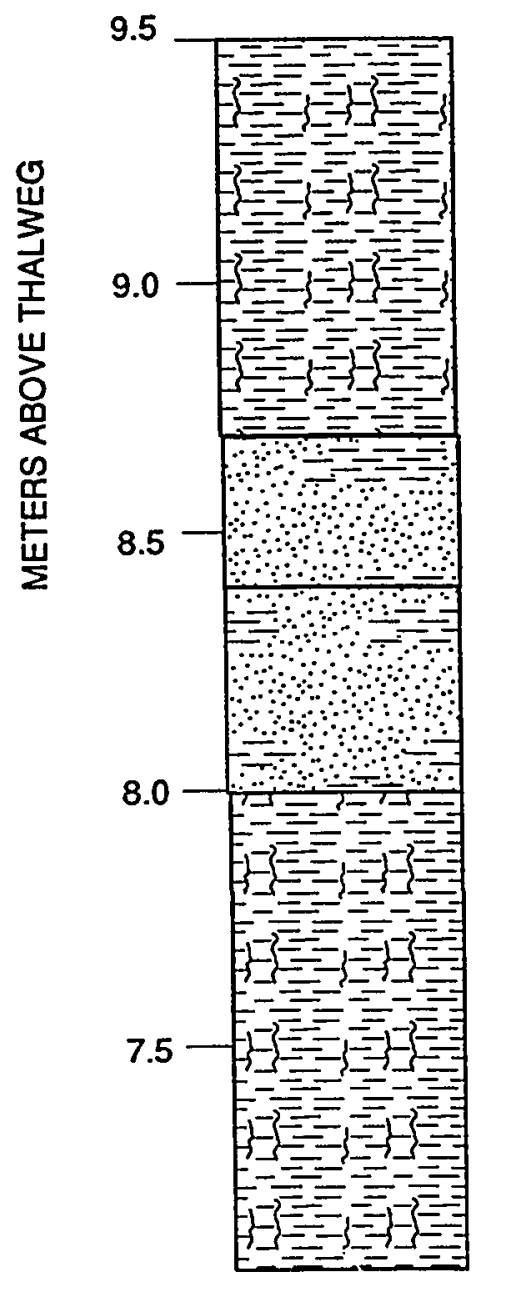

Disturbed sitt. Heavily cracked, with lots of carbonate. No structures. Root marks, pores common.

Sandy silt. No structures, no carbonate.

Very porous.

Silt and sand.

Silt with many root marks and pores. Bioturbated. 


\section{Section 86-6 (D) \\ (abandoned channel deposits - unit C)}

(continued from previous page)

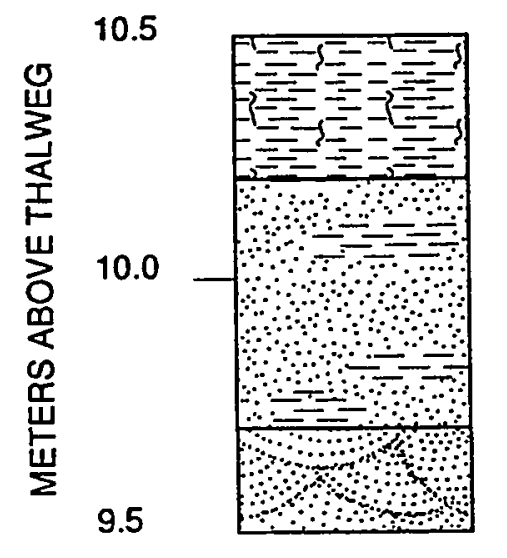

Bioturbated, plowed top soil with asbestos.

Finely laminated unconsolidated sandy silt with horizontal white deposits (gypsum?).

Somewhat cross bedded fine sand. 


\section{Section 86-11}

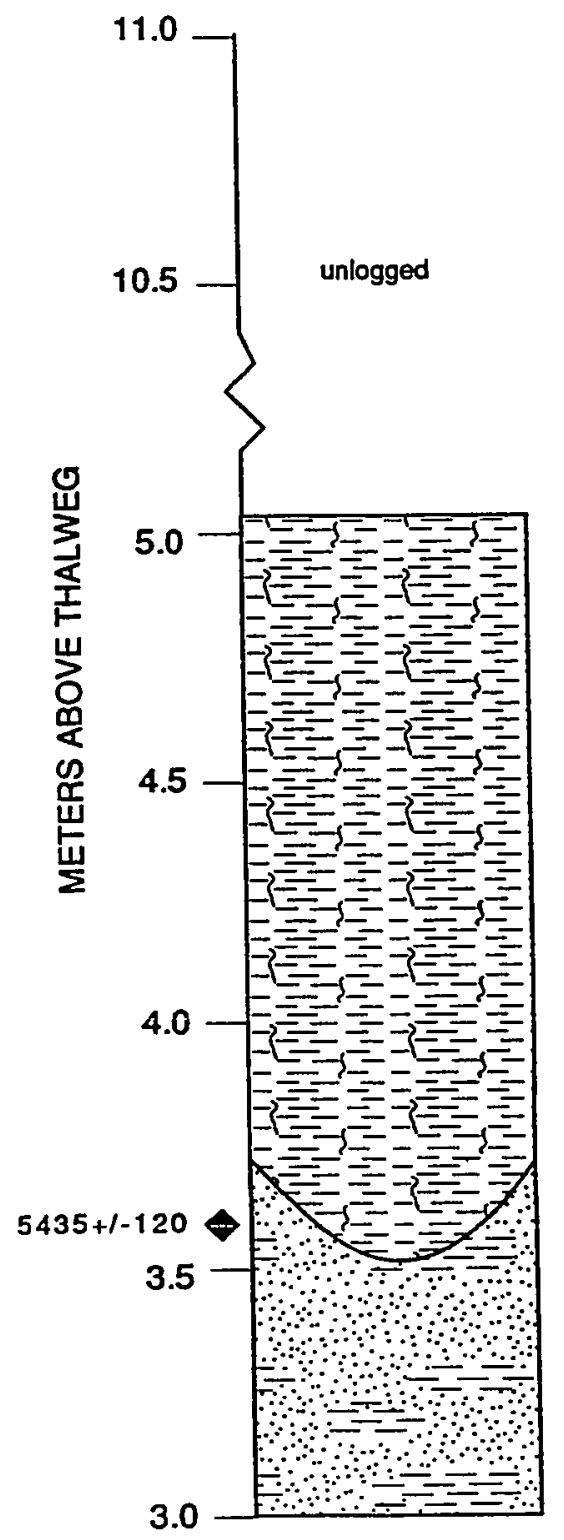

Sitt. Abundant plant fragments and root marks and burn zones.

Bioturbated.

Fine sand and silt. 


\section{Section 86-12}

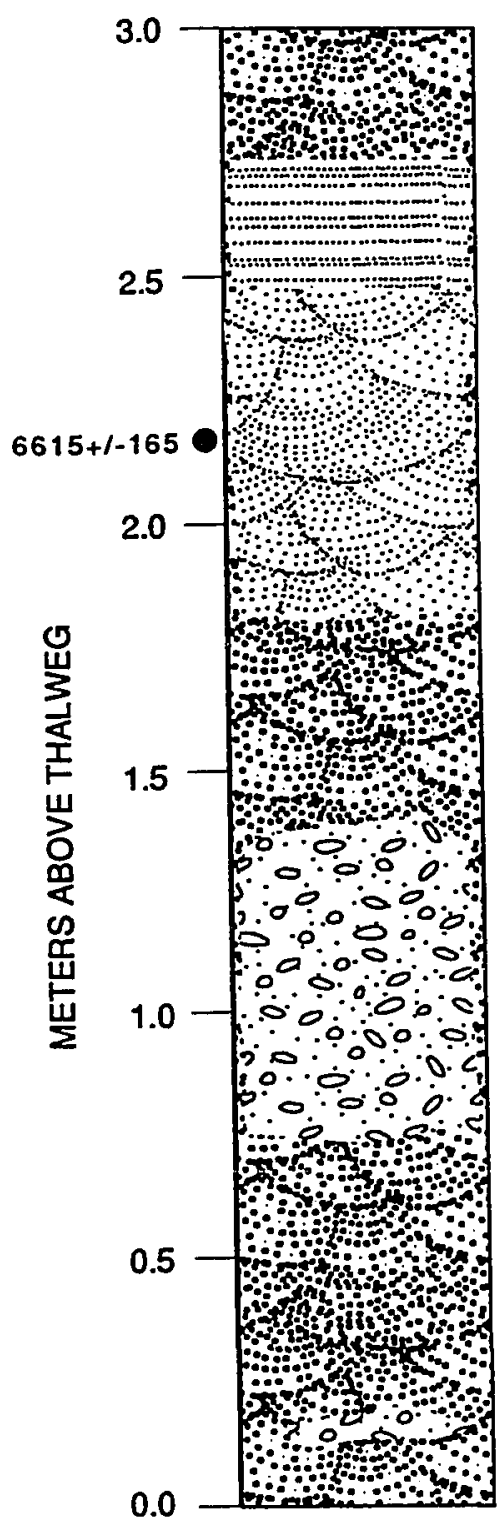

Cross bedded very coarse sand and gravelly very coarse sand. Some planar laminated and horizontally laminated. Lenticular and tabular shaped gravel lag deposits. 


\section{Section 86-12}

(continued from previous page)

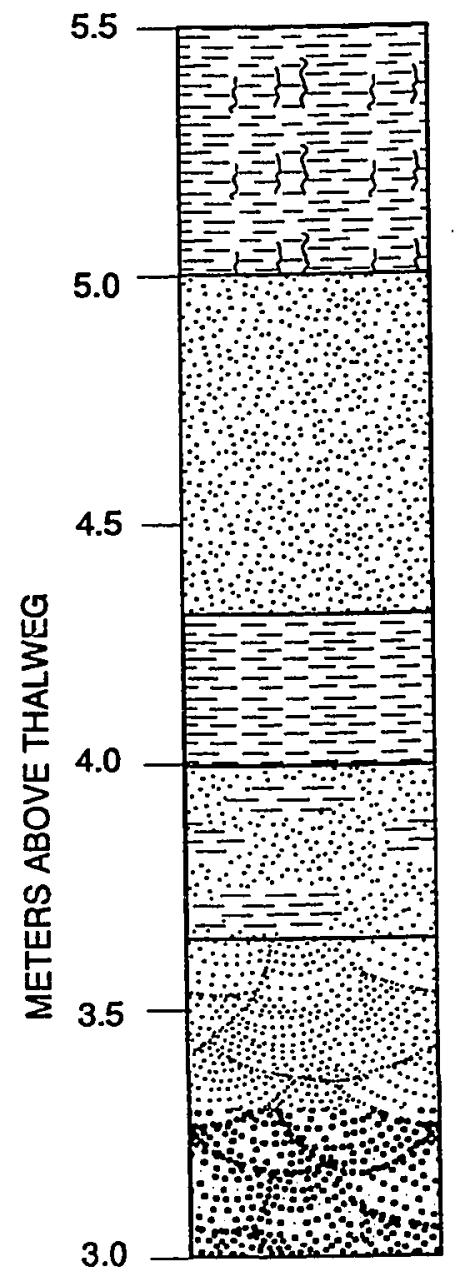

Mostly medium silt. Laminations largely disrupted.

Fine sand.

Laminated silt.

Silty fine sand.

Gravelly very coarse sand and very coarse sand. Cross bedded. 


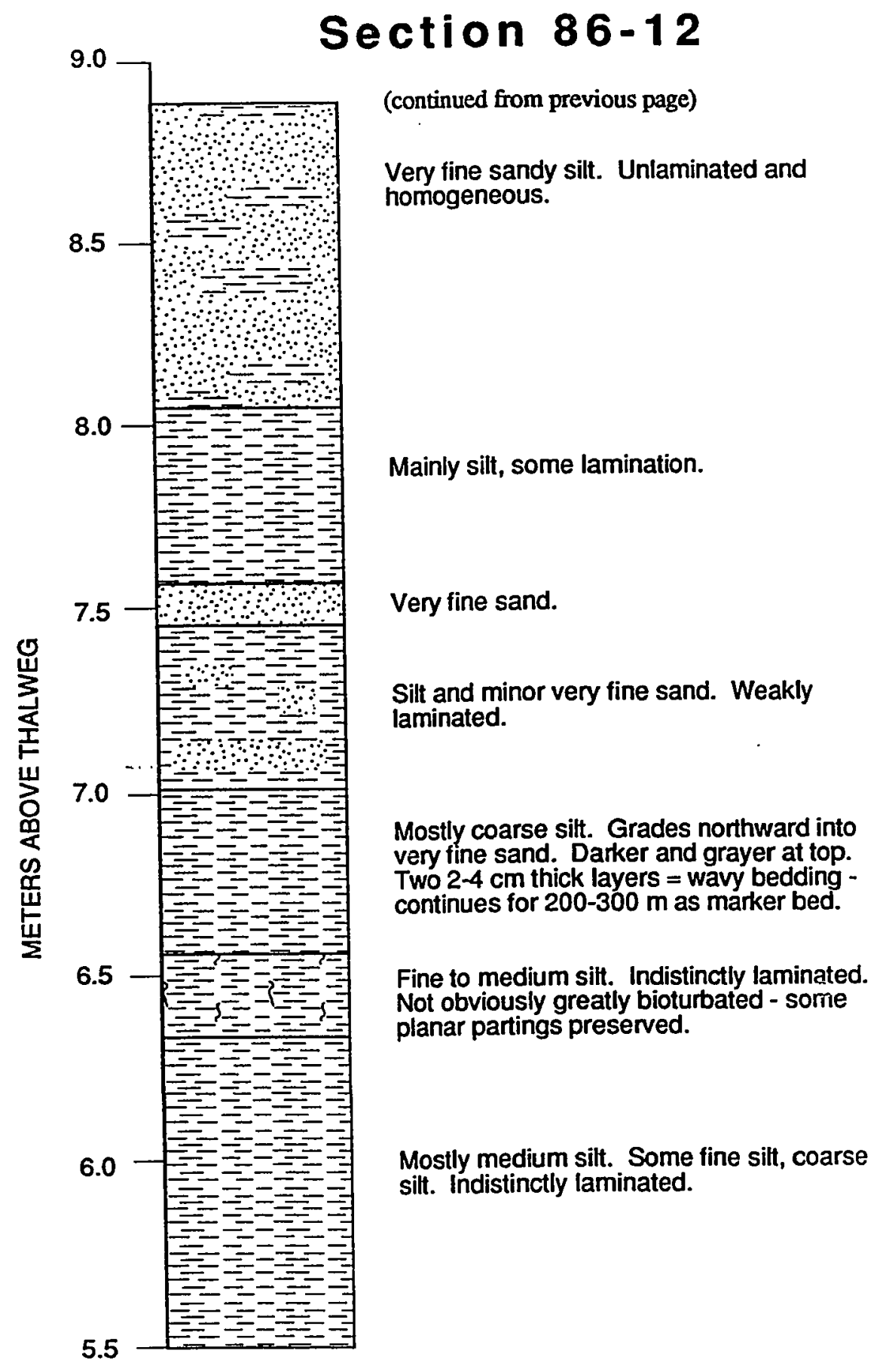




\section{Section 100}

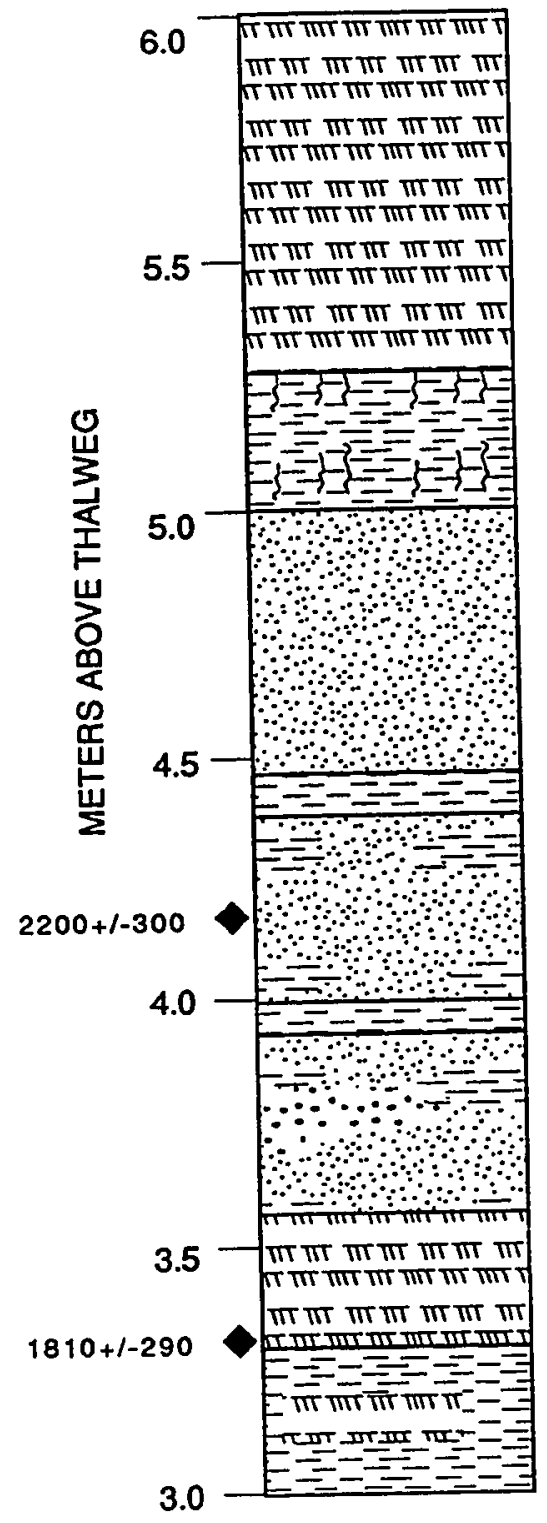

Cross laminated silt. Some very fine sand.

Clayey silt with clay (5Y 5/3) partings. Silt pebbles.

Cross laminated fine sand fining upward to fine silty sand.

Clayey silt with occasional clay partings.

Cross laminated sandy sitt and silty sand.

Clayey silt.

Parallel laminated sandy silt and silty sand. One discontinuous bed of planar fine to medium sand.

Cross laminated silt; trace of medium sand.

Parallel laminated and cross laminated sandy silt. 


\section{Section 100}

(continued from previous page)

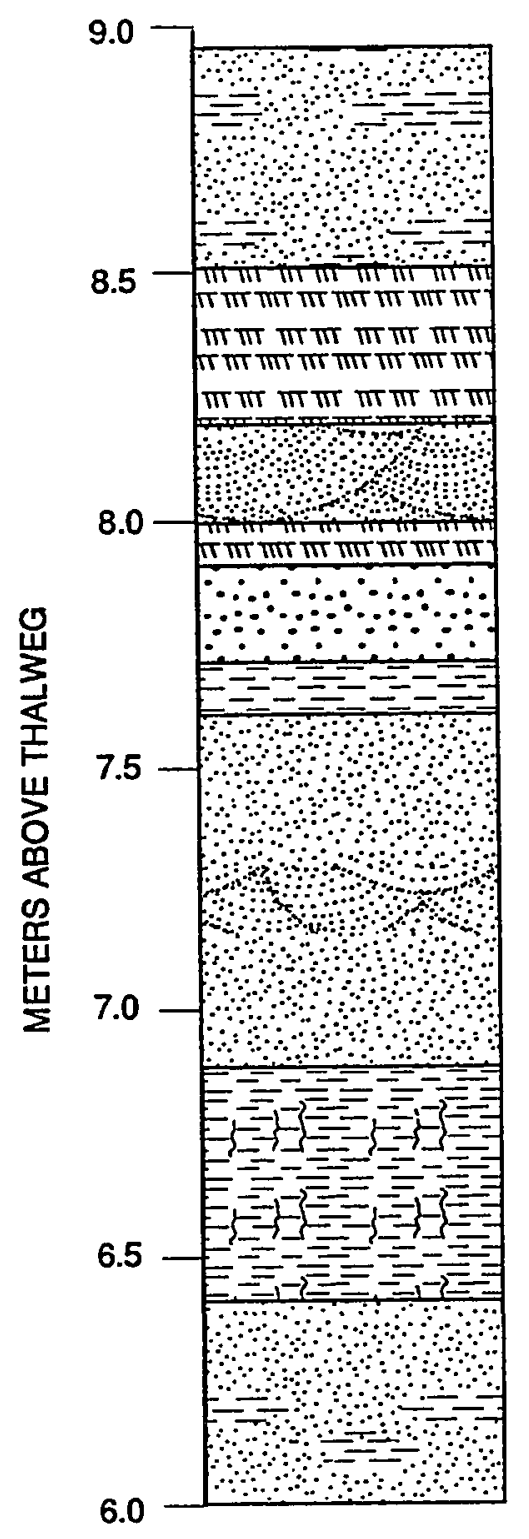

Clayey silt with occasional sand

partings. Clay increases top $13 \mathrm{~cm}$.

Sandy clay balls in lower part.

Cross laminated silty sand and sandy silt. Lower part laminated silt.

Cross laminated silty fine sand $(2 \mathrm{~cm}$ amplitude).

Parallel laminated silt with carbonized silt partings.

Medium sand with silty sand at top. Locally cross laminated.

Laminated sitt.

Massive planar fine sand with some cross laininaied fine silty sand.

Occasional silt partings. Fines upward.

Clayey silt and silty clay. Silts laminated. $\mathrm{CaCO} 3$ present. Stress cutans. Clay increasing upward. Some mudcracks.

Parallel laminated sandy silt. 1-2 $\mathrm{mm}$ laminations. Some clay partings. 


\section{Section 101}

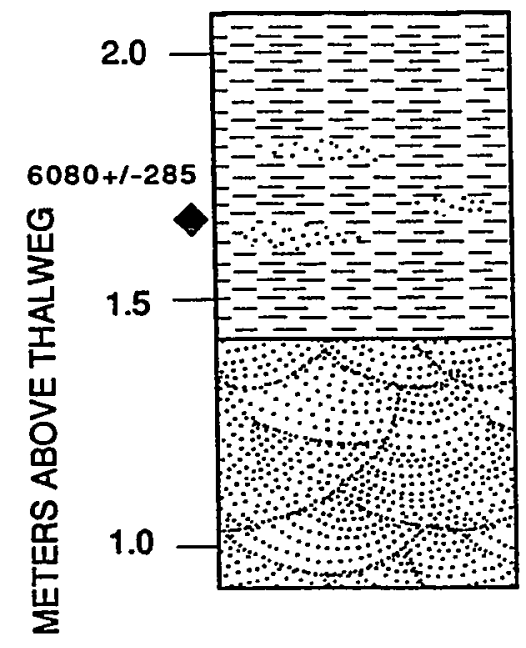

Parallel silt. Laminations 2-5 mm thick. Occasional sand partings.

Cross laminated fine sand. 


\section{Section 101}

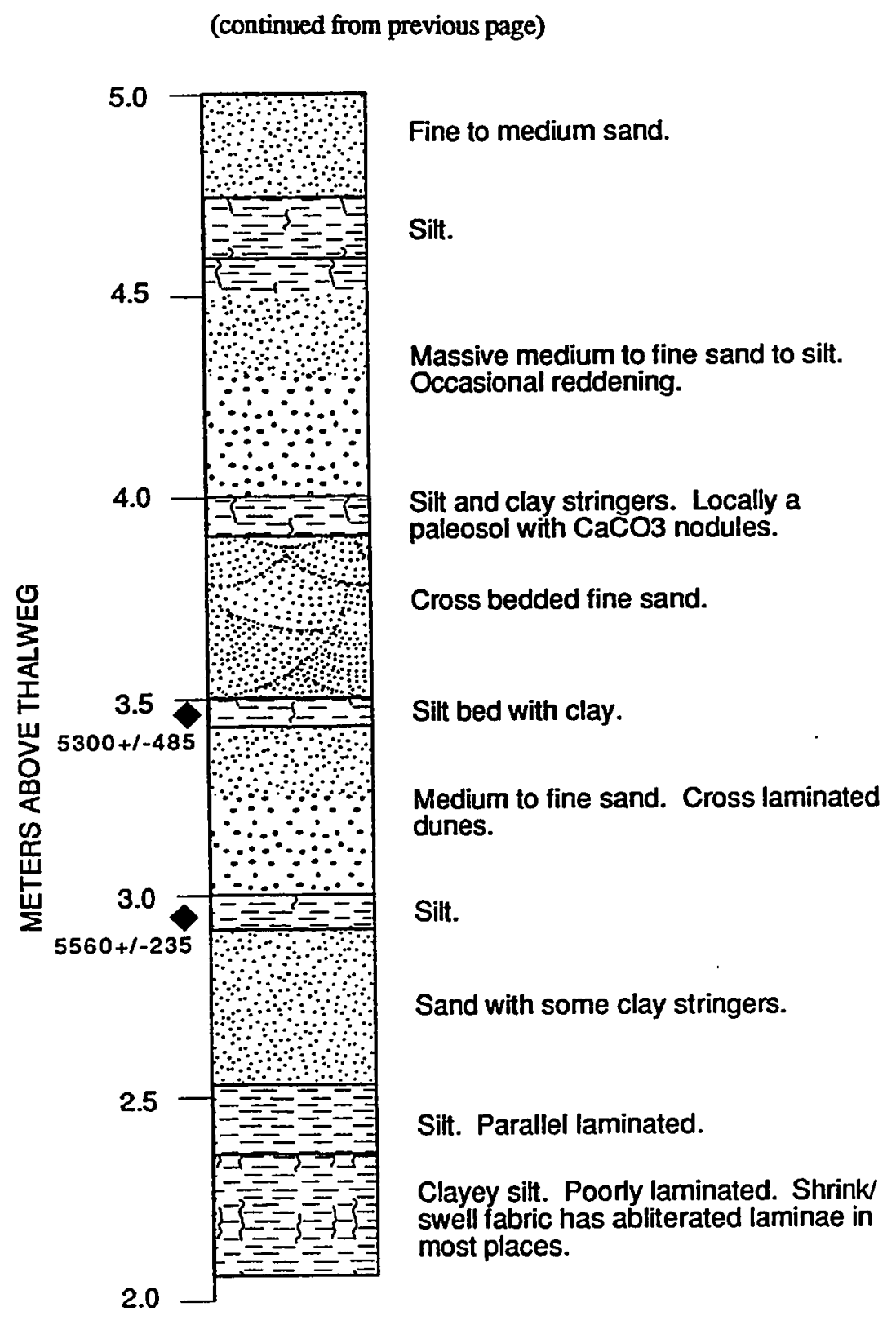




\section{Section 101}

(continued from previous page)

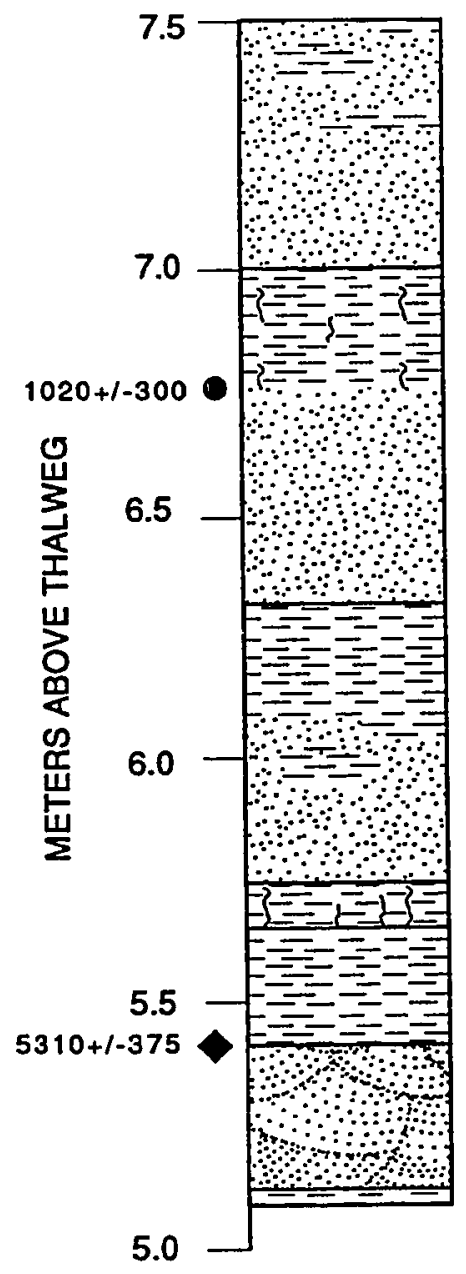

Fining up sand to silty sand. Mottled, many coarse tube pores. Trace of translocated clay.

Fines upward from massive silty fine sand to clayey silt with occasional silt stringers and trace of fine sand.

Thin silt parting.

Fines upward from fine sand to silty sand to sitt.

Paleosol. $\mathrm{CO} 3$ nodules $10 \mathrm{~cm}$ below top of bed.

Silt.

Cross laminated sand with $10 \mathrm{~cm}$ amplitude. Planar at top.

Silt. Parallel lamination. 


\title{
Section 101
}

\author{
(continued from previous page)
}

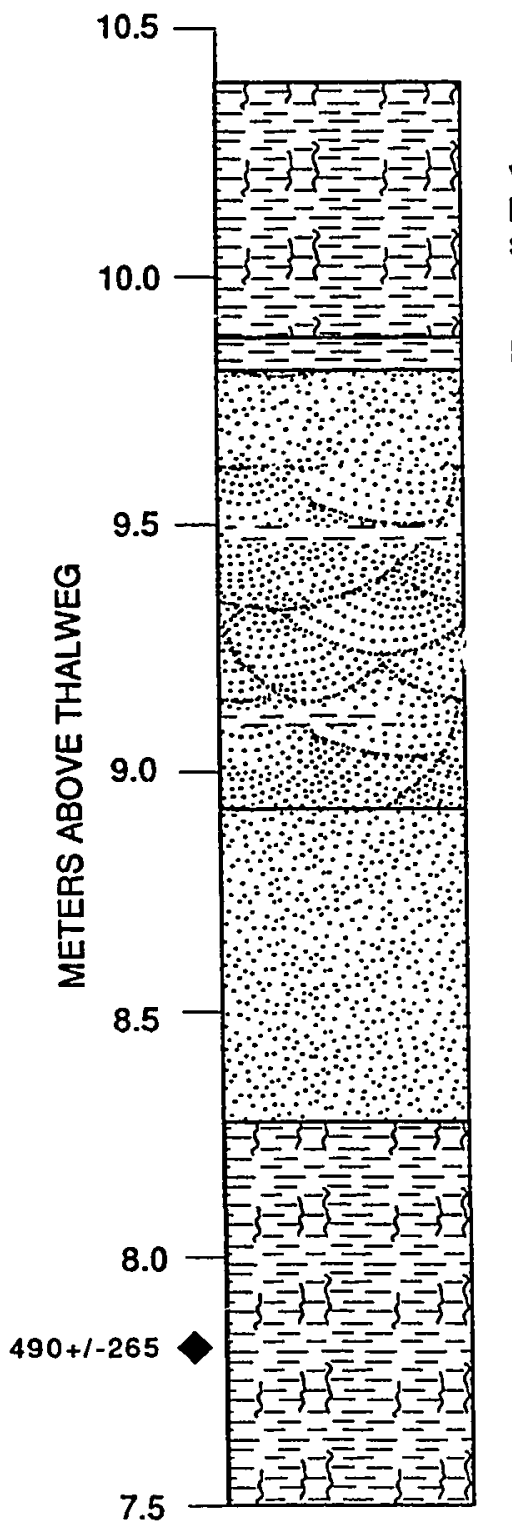

Vesicular, porous soil, Ap, many filled

burrows. Originaly a thinly laminated

silt with trace of clay and medium sand.

Laminated silt.

Massive silty fine sand.

Massive silty fine sand. Locally cross

laminated and rippled. Few silt stringers.

$5 Y 6 / 3$ (d).

Massive fine sand. Contains few

rounded silt pebbles.

Silty clay. Stress cutans; $\mathrm{CaCO} 3$ in pores. Common mottles. Many pores. Also CaSO 4 present. Some rounded silt pebbles in middle sector. Paleosol. 


\section{Section 102}

Planar medium sand. Very loose.

号

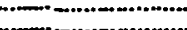

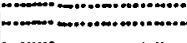

क

ш 3.5

崖 


\section{Section 102}

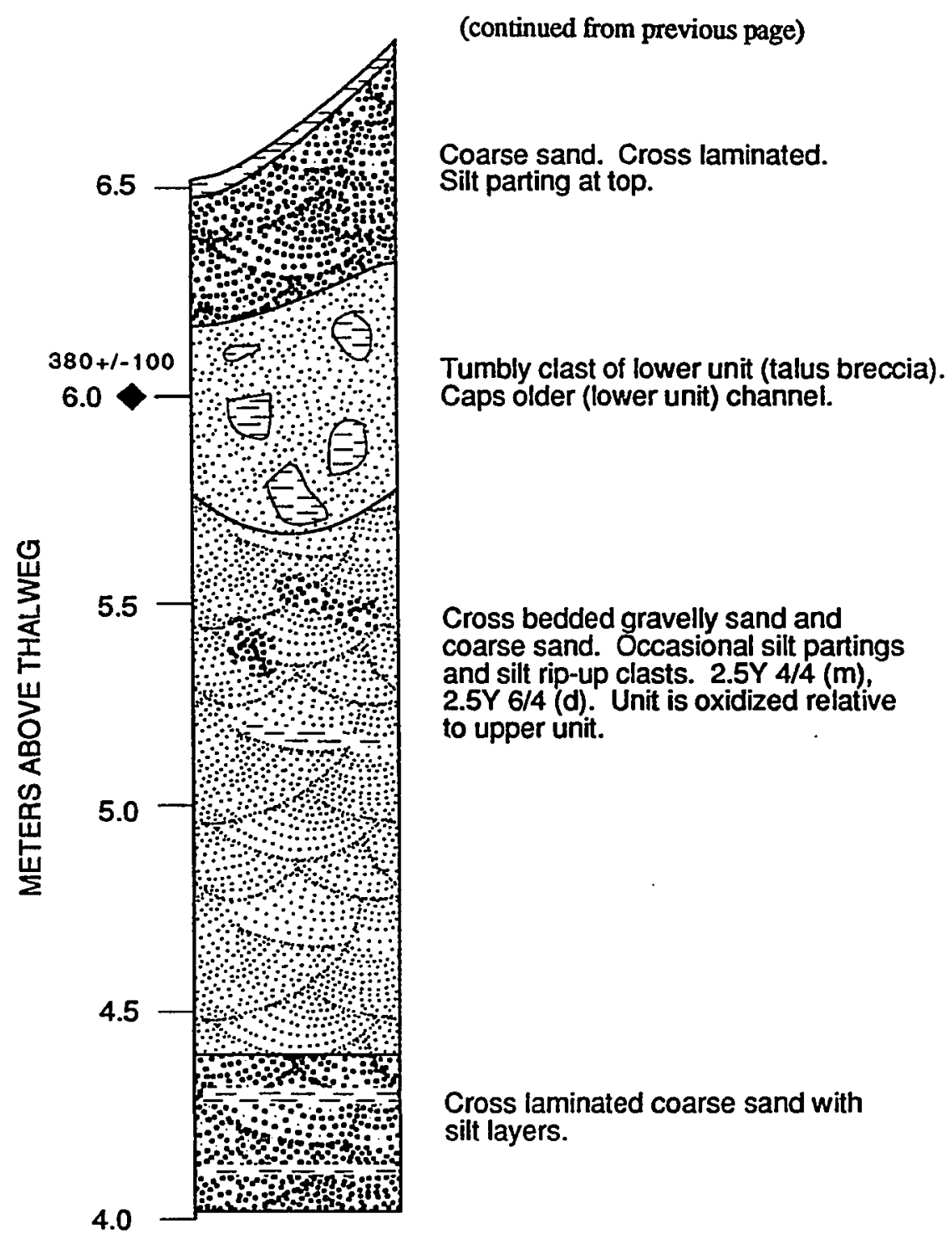




\section{Section 102}

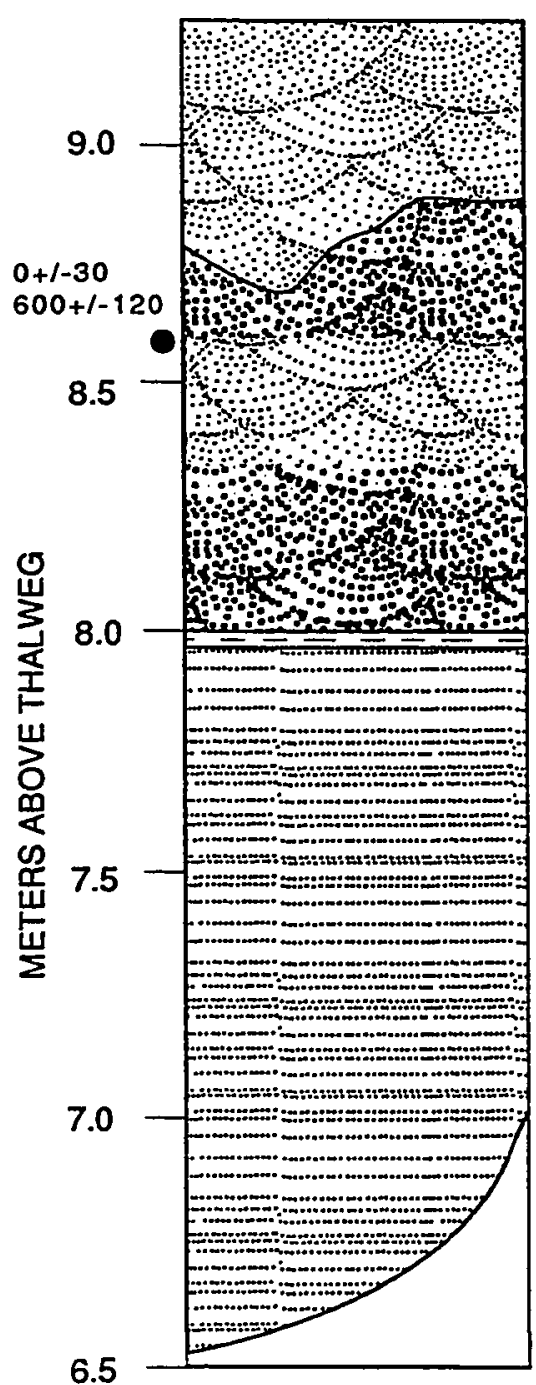

(continued from previous page)

Cross laminated and ripple drift silty fine sand. Many root marks. Scour fill.

Medium to fine sand. Cross bedded with $40 \mathrm{~cm}$ amplitude. Some root marks, many charcoal flecks.

Silt parting.

Fine sand. $1 \mathrm{~mm}$ laminations. 


\section{Section 103}

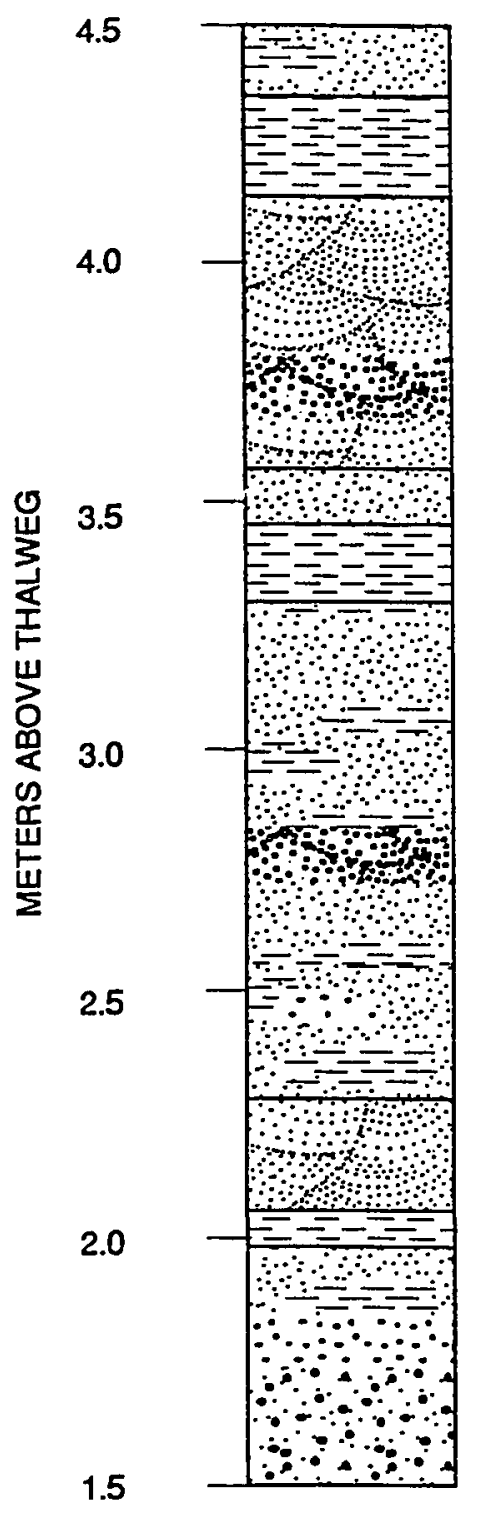

Sandy silt.

Sandy silt with clay partings.

Massive fine to medium sand. Cross

bedded and cross laminated $(8 \mathrm{~cm})$.

Fine to medium sand.

Blocky sitt with some clay.

Silty sand.

Coarse to medium cross laminated sand.

Silt parting. Sand lenses. Rip-up clasts.

Cross laminated fine sand.

Silt parting.

Fine sand with silt.

Coarse to medium sand. 


\section{Section 103}

(continued from previous page)

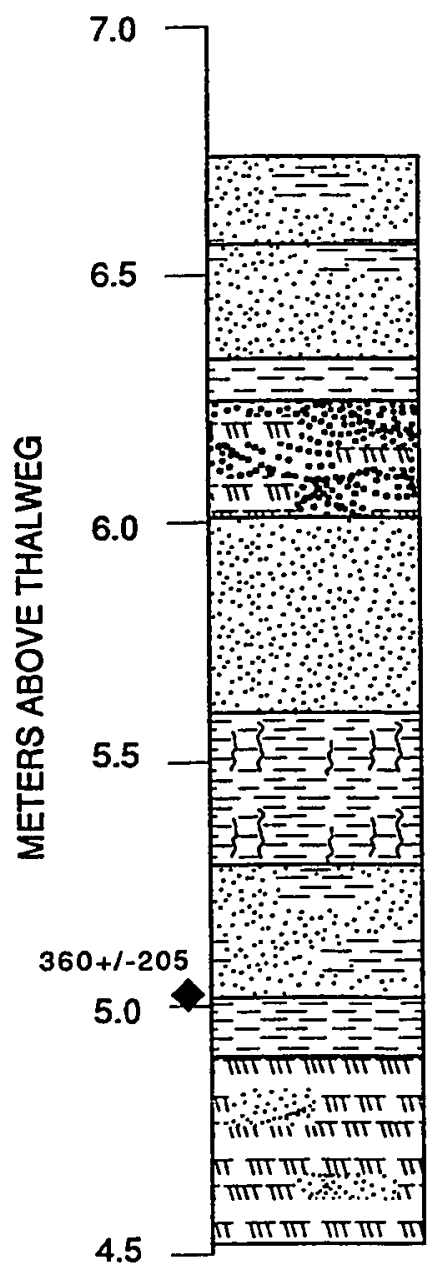

Silty sand, massive, burrowed; basal laminae nearly obliterated. $1 \mathrm{~cm}$ fine sand at base.

Silty sand; many burrows and rip-up silt clasts. Some charcoal. Poorly bedded.

Silt lenses.

Cross laminated silty medium sand. Many silt clasts.

Fine sand, poorly laminated, lots of small silt rip-ups.

Minor paleosol. Clayey silty fine sand. Stree cutans, charcoal, sitt laminae. disrupted.

Fine silty sand; laminated silt lenses $1 / 2 \mathrm{~cm}$ thick. Burn layer.

Laminated clayey silt ( $30 \%$ destroyed). Minor paleosol.

Cross laminated sandy silt; $10 \mathrm{~cm}$ amplitude on cross beds. 